GEOLOGICAL SURVEY CIRCULAR 812

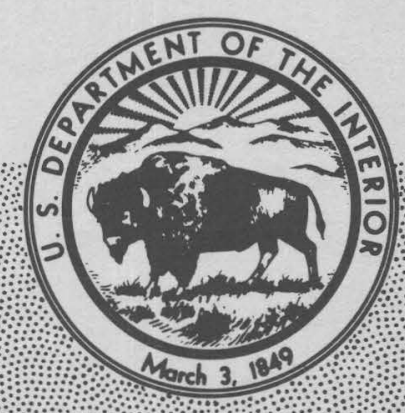

Structural Framework, Stratigraphy, and

Petroleum Geology of the Area of

Oil and Gas Lease Sale No. 49 on the

U.S. Atlantic Continental Shelf and Slope 

Structural Framework, Stratigraphy, and Petroleum Geology of the Area of Oil and Gas Lease Sale No. 49 on the U.S. Atlantic Continental Shelf and Slope Robert E. Mattick and Jacqueline L. Hennessy, editors

GEOLOGICAL SURVEY CIRCULAR 812 


\section{United States Department of the Interior CECIL D. ANDRUS, Secretary}

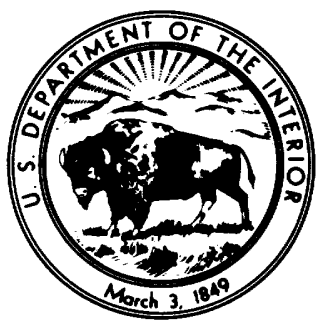

\section{Geological Survey}

H. William Menard, Director

Library of Congress Catalog-card No. $80-600090$

Any use of trade names in this publication is for descriptive purposes only and does not constitute endorsement by the U.S. Geological Survey. 


\section{CONTENTS}

Abstract

Introduction

Acknowledgments

Processing of seismic data, by Robert C. Anderson,

William C. Patterson, and Richard Wise

Geologic setting, by Kenneth C. Bayer and

Robert E. Mattick

Structural framework, by John A. Grow and

Kim D. Klitgord

Seismic-refraction data

Multichannel seismic-reflection data

Magnetic data

Gravity data

The ocean-continent boundary and subsidence history

Stratigraphy

Foraminiferal stratigraphy and paleoecology, by

C. Wylie Poag

Pre-Cretaceous rocks

Cretaceous

Paleocene

Eocene

Oligocene

Miocene
Page

1 Stratigraphy - Continued

2 Foraminiferal stratigraphy and paleoecology -

4 Continued

Pliocene

Pleistocene

Holocene

Acoustic stratigraphy, by John S. Schlee

Acoustic units

Discussion

Petroleum geology

General comments, by Robert E. Mattick and

O. W. Girard, Jr.

COST No. B-2 well, by Peter A. Scholle

Shelf, by Robert E. Mattick and Kenneth C. Bayer

Slope, by Robert E. Mattick, Peter A. Scholle, and

O. W. Girard, Jr.

Organic matter in slope sediments

Reservoir rock on the slope

Potential hydrocarbon traps on the slope

Summary and conclusions

Geology

Petroleum geology

References cited
Page

47

47

48

48

58

72

75

75

79

84

87

87

88

89

93

93

94

97

\section{ILLUSTRATIONS}

Figure 1. Map showing location of lease-sale tracts, drill holes, and seismic-reflection grid on the mid-Atlantic continental margin of the United States

2. Flow chart of the first-pass processing steps performed by the USGS on multichannel seismic-reflection profiles 11,12 , and 13

3. Diagrammatic cross section of the Baltimore Canyon Trough

4-6. Structure-contour maps of the mid-Atlantic continental margin of the United States showing depth to the top of:

4. Upper Cretaceous rocks

5. Lower Cretaceous rocks

6. The acoustic basement

7, 8. Isopach maps of the mid-Atlantic continental margin of the United States showing:

7. Thickness of Lower Cretaceous and older sedimentary rocks above the acoustic basement

8. Total sediment thickness between the sea floor and the acoustic basement

9. Map showing locations of seismic-refraction surveys discussed in text

10. Cross section from outer shelf to rise based on recent seismic-refraction surveys

11. Line drawings showing strong reflectors, interval velocities, and inferred ages of horizons interpreted from seismic-reflection profiles $9,10,6$, and 2

12. Part of CDP multichannel seismic profile 2 having vertical scale in depth

13. Part of CDP multichannel seismic profile 6 , which crosses the Continental Slope

14, 15. Parts of CDP multichannel seismic profiles having vertical scale in depth:

14. Profile 10

15. Profile 9 
FIgURE 16. Graphs showing velocities and deposition rates at the COST No. B-2 well site

17. Aeromagnetic anomaly map of the Baltimore Canyon Trough area

18. Edge and dike models assumed in making magnetic depth estimates

19, 20. Diagrams showing a comparison between seismic-reflection data and magnetic depth estimates for:

19. Seismic lines 9 and 2

20. Seismic lines 6 and 10

21. Contour map showing estimated depth to magnetic basement in the Baltimore Canyon Trough area

22. Free-air gravity map of the Baltimore Canyon Trough area

23. Profile showing gravity anomalies at the continental margin along seismic line 6

24. Geologic section across the ocean-continent boundary near seismic profile 2

25. Geologic section based on interpretation of seismic profile 6 , which crosses the ocean-continent boundary

26. Graph showing subsidence rates of shelf and adjacent slope-rise areas in the Baltimore Canyon Trough area

27. Map of the United States mid-Atlantic margin showing locations of lease tracts, seismic grid, sample sites, and cross sections illustrated in figures 28-35

28. Schematic geologic cross section of the Baltimore Canyon Trough

29. Schematic paleoecologic cross section of the Baltimore Canyon Trough

30-32. Schematic dip sections showing stratigraphy and paleoecology of sedimentary rocks in the:

30. Northern Baltimore Canyon Trough area

31. Southern Baltimore Canyon Trough area

32. Central Baltimore Canyon Trough area

33. Schematic strike section showing stratigraphy and paleoecology of the Coastal Plain segment of the Baltimore Canyon Trough area

34. Schematic stratigraphic and paleoecologic section through four wells that penetrated Jurassic rocks within the Baltimore Canyon Trough area

35. Schematic strike section showing stratigraphy and paleoecology of upper Cenozoic rocks at the seaward margin of the Baltimore Canyon Trough

36. Schematic diagram of a depositional sequence showing the different types of relations that can exist along the same unconformity, and a chronostratigraphic section showing where the sedimentary record is most complete

37. Schematic diagrams showing possible types of stratigraphic relations found at the upper and lower bounding surfaces in a depositional sequence

38. A part of CDP multichannel seismic profile 6 off southern New Jersey

39. The same part of seismic profile 6 that is shown in figure 38 but on which the acoustic units are labeled

40. A generalized lithologic section based on 13 holes drilled near the seaward edge of the Atlantic Coastal Plain from North Carolina to New York

41. Diagram showing environments of deposition as represented in the generalized lithologic section in figure 40

42. The depth and time section of seismic line 6 under the seaward edge of the Continental Shelf, Continental Slope, and upper Continental Rise

43. Maps showing characteristics of unit A in the Baltimore Canyon Trough area

44. A depth section along seismic line 12 parallel to the coast

45-49. Maps of the Baltimore Canyon Trough area showing thickness, depositional environment, and averaged interval velocity of:

45. Unit B

46. Unit $\mathrm{C}$

47. Unit D

48. Unit $\mathrm{E}$

49. Unit $\mathrm{F}$

50. An enlargement of a part of figure 38 (line 6 ) to show the delta built during accumulation of unit $\mathrm{F}$

51, 52. Maps of the Baltimore Canyon Trough area showing thickness, depositional environment, and averaged interval velocity of:

51. Unit $\mathrm{G}$

52. Unit $\mathrm{H}$

53-55. Isopach maps of the Baltimore Canyon Trough area:

53. Probable Middle and Lower Jurassic and Triassic sedimentary rocks (units A and B combined)

54. Inferred Cretaceous and Upper Jurassic sedimentary rocks (units C, D, and E combined)

55. Inferred Cenozoic sedimentary rocks (units F, G, and $\mathrm{H}$ combined)

56. Structure-contour map of the top of basement rocks in the Baltimore Canyon Trough area 
FIGURE 57. Schematic section through the northern Scotian basin showing main stratigraphic units

58. Part of seismic profile 15 showing anticlinal structures along the shelf edge in the Baltimore Canyon Trough area

59. Generalized plot of lithologies and depositional environments of sediments in the COST No. B-2 well

0-63. Graphs for the COST No. B-2 well showing:

60. Comparison of density log curve of porosity with measured core porosities and empirically determined permeabilities

61. Comparison of various measures of thermal maturity as a function of depth

62. Summary and comparison of analyses of organic content of sediments

63. Summary and comparison of type of organic matter in samples

64. Diagrammatic cross section illustrating potential hydrocarbon traps in the Baltimore Canyon Trough area

65. Geologic model derived from seismic bright spot

66. Interpreted depth section computed along seismic-reflection line 2

67. Diagram presenting a geologic interpretation of the part of seismic profile 2 shown in figure 66

\section{TABLES}

TABLE 1. Acoustic units delineated in the Baltimore Canyon Trough area

2. A comparison of the thickness of acoustic units from seismic line 2 with the thickness of rocks of equivalent age in the COST No. B-2 well

3. Seismic facies present in the Baltimore Canyon Trough area

4. Summary of combustion and thermal analysis of Cretaceous sapropels collected during DSDP Leg 44 from site 391, Blake Basin 


\section{CONVERSION FACTORS}

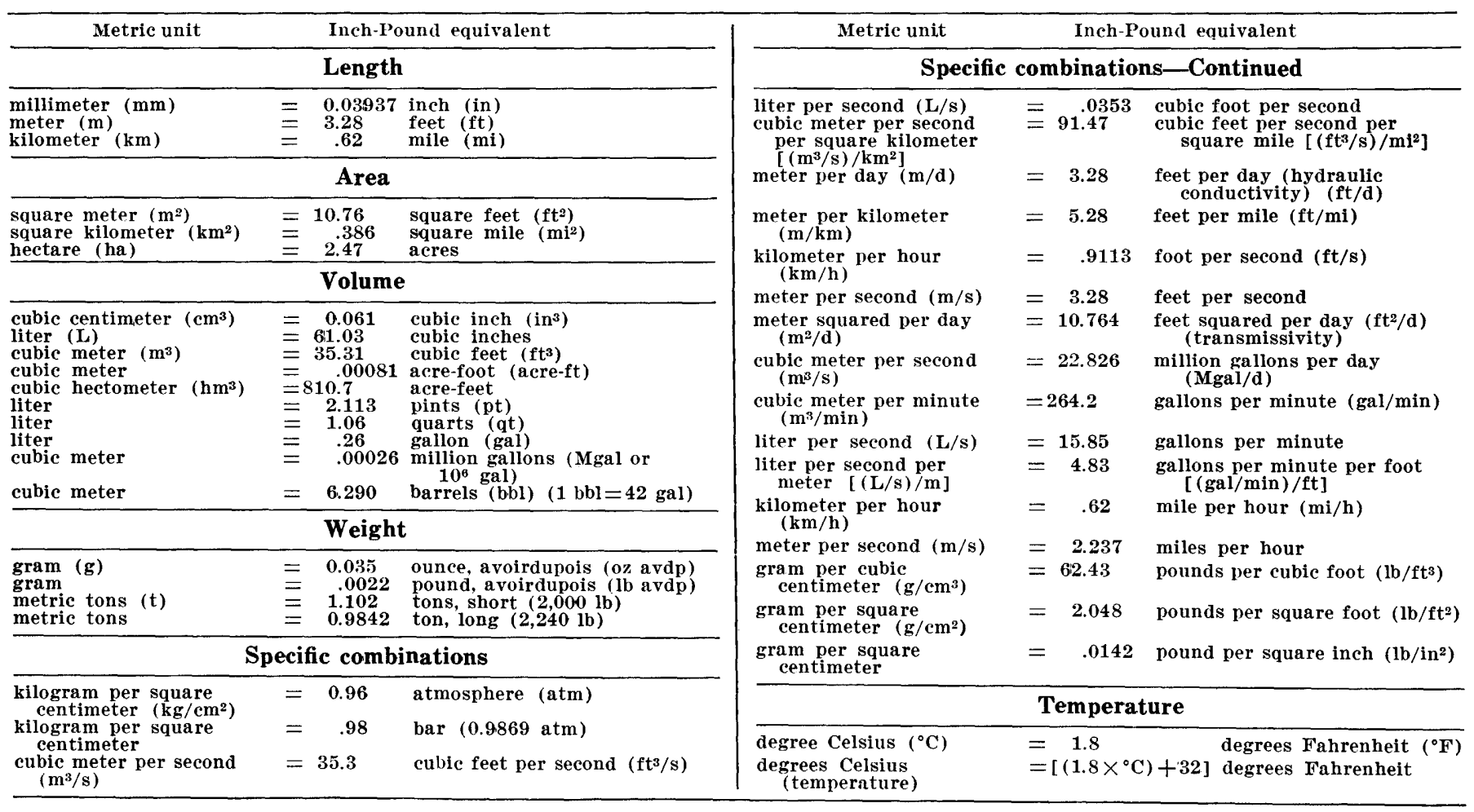




\title{
Structural Framework, Stratigraphy, and Petroleum Geology of the Area of Oil and Gas Lease Sale No. 49 on the U.S. Atlantic Continental Shelf and Slope
}

\author{
Robert E. Mattick and Jacqueline L. Hennessy, editors
}

\section{ABSTRACT}

On September 23, 1977, the U.S. Department of the Interior announced the tentative selection of 136 tracts for Sale No. 49 of oil and gas leases in the Baltimore Canyon Trough on the U.S. Atlantic Continental Shelf and Slope. This report summarizes the geology and petroleum potential of the area.

The Baltimore Canyon Trough is an elongate, seawardopening sedimentary basin filled by as much as $14 \mathrm{~km}$ of Mesozoic and Cenozoic sedimentary rocks. The basin first formed under the New Jersey shelf and gradually spread west and south as the area subsided after the rifting that formed the Atlantic basin.

Rocks of the Triassic and Jurassic Systems together are more than $8 \mathrm{~km}$ thick in a depocenter areally restricted to the northern part of the trough. Basal Jurassic rocks are apparently nonmarine sedimentary rocks bedded with evaporite deposits. Direct evidence that some salt is in the basal Jurassic section comes from the Houston Oil and Minerals 676-1 well, which penetrated salt at a depth of about $3.8 \mathrm{~km}$.

During the Middle and Late Jurassic, more open marine conditions prevailed than in the Early Jurassic, and carbonate banks and reefs formed discontinuously along the seaward side of the shelf. Sand flats likely occupied the central part of the shelf, and these probably graded shoreward into nonmarine red beds that accumulated in a bordering coastal plain. Thick nonmarine sands and silty shales of Late Jurassic age were deposited in what is now the nearshore and midshelf area. These sedimentary rocks probably grade into thick marine carbonate rocks near the present shelf edge.

During the Cretaceous, less sediment accumulated (about 4 $\mathrm{km}$ ) than during the Jurassic, and most was deposited during Early Cretaceous time. The Cretaceous units show two main trends through time-a diminishing rate of sediment accumulation and an increase in marine character of sediments. During the Middle and Late Cretaceous, calcareous sand and mud filled the basin, buried the shelf-edge reefs and later spilled across the reefs into the oceanic basin as worldwide sea level reached a maximum.

Cenozoic deposits are spread over the present shelf and adjacent Coastal Plain in overlapping sheets of marine and nonmarine sediment. The maximum thickness $(1.5 \mathrm{~km})$ is along the outer part of the present shelf.

Major tectonic deformation in the Baltimore Canyon Trough area appears to have terminated near the end of the Early
Cretaceous, when at least one large mafic intrusion (Great Stone dome) was emplaced. Upper Cretaceous sedimentary rocks are arched above older uplifted fault blocks near the shelf edge; this arching may be the result of draping due to differential compaction or, perhaps, minor movement of the fault blocks during Late Cretaceous time.

The dominance of terrestrial over marine-derived organic matter in sediment samples from the COST No. B-2 well indicates that economic amounts of liquid petroleum hydrocarbons were probably not generated in the area but suggests a high potential for generation of wet or dry gas. Supporting evidence for the presence of natural-gas deposits on the slope comes from AMCOR 6021, the upper $305 \mathrm{~m}$ of which penetrated sediments that contained methane, ethane, and propane. Texaco, Inc., has announced that its 598-1 well yielded nearly $479,000 \mathrm{~m}^{3}$ of natural gas per day from two zones during early testing. Further indication of possible gas deposits comes from analyzing the amplitude (bright spots) of seismic data.

Geochemical studies of the COST No. B-2 well have shown that the shelf area of the Baltimore Canyon Trough has a relatively low geothermal gradient today and that it apparently has had a gradient as low or even lower throughout the Cretaceous to Holocene. A controversy exists concerning the maturity of the basal sediments penetrated by the COST No. B-2 well. Although significant amounts of gaseous hydrocarbons may have been generated, large amounts of liquid petroleum hydrocarbons probably have not yet been generated.

Although the sediments penetrated in the COST No. B-2 well are predominantly nonmarine to marginal marine, regional geology and seismic data indicate that sections to the east and southeast are probably more marine. By analogy with the Scotian Shelf, a more fully marine section would be more likely to contain source rocks than would nonmarine to marginalmarine sections. Studies of the Scotian Shelf indicate that the percentage of amorphous organic material, which can be converted to petroleum at relatively low temperatures, tends to increase in the direction of deep-water environments. Petroleum could also have been generated under the present lower slope and rise in basin facies that are rich in organic matter and then could have migrated to reservoirs along the shelf edge. Possible patterns of thermal maturity (that is, sufficiently high rock temperatures to have generated hydrocarbons) are difficult to predict, but geothermal gradients might increase toward the shelf edge, where major faults and intrusions have been postulated from seismic data. 


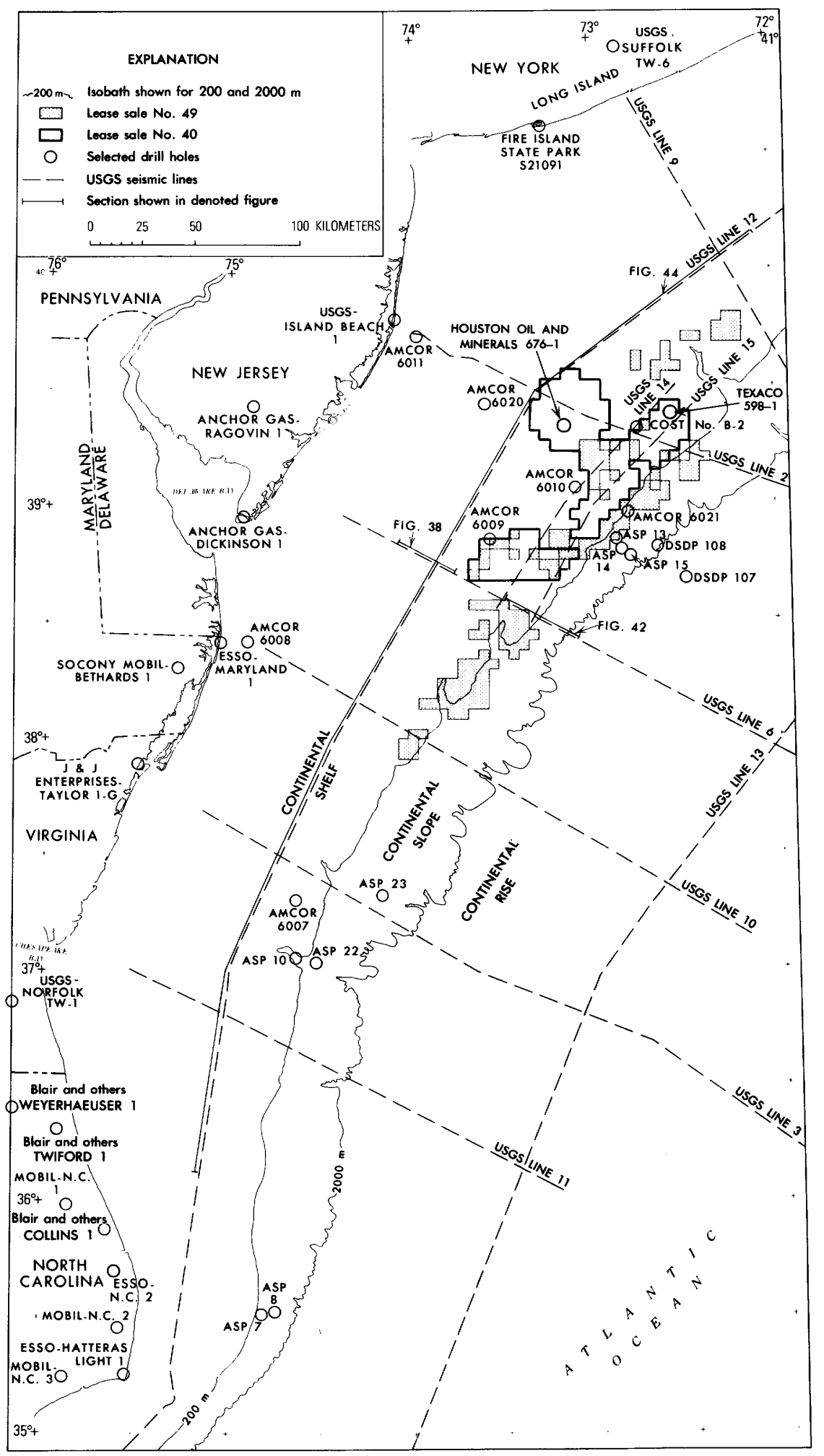

FIGURE 1.-Map showing location of lease-sale tracts, drill holes, and seismic-reflection grid on the mid-Atlantic continental margin of the United States. Locations of sections for figures 38, 42, and 44 are shown also. AMCOR, Atlantic Margin Coring Project; ASP, Atlantic Slope Project; DSDP, Deep Sea Drilling Project. 
On the shelf, potential hydrocarbon traps are associated with diapirs, drape structures over uplifted fault blocks, and faults. Seismic evidence suggests that although these potential traps are sparse under the inner-shelf and midshelf areas, they are more common along the landward edge of the shelf-slope break.

Along the shelf edge, good possibilities exist for numerous structural traps related to rift or prerift tectonism. On seismic sections, uplifted fault-block structures appear to be numerous, to be about $5-10 \mathrm{~km}$ wide, and to involve several hundred meters of relief. Movement of these basement blocks may have continued throughout Cretaceous time; if so, the chance of finding significant anticlinal and fault-related hydrocarbon traps would be enhanced.

Seismic and indirect geologic evidence suggests the presence of potential hydrocarbon traps on the present slope that are related to a paleoshelf margin. What is now the Continental Slope is believed to be underlain by sequences of Jurassic and Lower Cretaceous sedimentary rocks deposited, during periods of fluctuating sea level, above a carbonate platform or possibly atop high-standing basement blocks. The landward shift of the present shelf edge relative to the buried paleoshelf edge is 20-30 km.

The importance of the paleoshelf edge, as far as petroleum is concerned, is the fact that it is a large high that could contain zones of very porous carbunate rock in both reefal and carbonate platform material. "'his high is apparently bordered on its seaward flank by at least $6 \mathrm{~km}$ of slope sediments rich in organic matter. Furthermore, thick shale beds, which probably overlie the paleoshelf, could provide a relatively impermeable seal needed to trap migrating fluids.

\section{INTRODUCTION}

On September 23, 1977, the U.S. Department of the Interior announced the tentative selection of 136 tracts totaling 774,273 acres for proposed Oil and Gas Lease Sale No. 49 on the mid-Atlantic Outer Continental Shelf (OCS) and the upper part of the Continental Slope (fig. 1). The tracts are in water depths between about 35 and $1,500 \mathrm{~m}$ (fig. 1). The sale, held in February 1979, was the second (the first was Sale No. 40 (fig. 1)) in the Baltimore Canyon Trough area. The primary purpose of this report is to summarize the general geology of the area insofar as it pertains to petroleum potential.

Much of our information has been derived from indirect evidence-chiefly seismic-reflection profiles. Since 1973, the USGS has contracted for several thousand kilometers of CDP (commondepth-point) profiles on the Atlantic continental margin (Schlee and others, 1976; Schlee, Martin, and others, 1977; Dillon and others, 1979; Grow and others, 1979). The processing of seismic data is described by Robert C. Anderson, William C. Patterson, and Richard Wise (this volume).

The results from the COST No. B-2 well have been used by C. Wylie Poag (this volume) and John
S. Schlee (this volume) to discuss the stratigraphy and depositional environments of the Baltimore Canyon Trough area. These two authors, however, use somewhat different approaches. The interpretations of Poag are based primarily on preliminary analyses of forminiferal assemblages derived from 16 offshore borings and on a review of published stratigraphic investigations of Coastal Plain wells. His interpretations of onshore stratigraphy are based largely on data taken from the comprehensive compilation by Brown, Miller, and Swain (1972; also see references therein). Two major programs (besides the COST No. B-2 well) provided sediment samples upon which the foraminiferal analyses were based:

1. In 1967, a consortium of oil companies conducted their Atlantic Slope Project (ASP) aboard the M/V Caldrill I (Minard and others, 1974; Weed and others, 1974; Poag, 1978). They drilled coreholes at seven sites along the base of the Continental Slope adjacent to the Baltimore Canyon Trough. Sediment penetration was limited to approximately 330 $\mathrm{m}$, and water depth at hole sites was as much as $1,500 \mathrm{~m}$.

2. In 1976, the USGS (U.S. Geological Survey) undertook the Atlantic Margin Coring (AMCOR) Project (Hathaway and others, 1976). Cores were recovered at 19 sites ( 9 in the Baltimore Canyon Trough area); these sites and cores are designated AMCOR in this volume (fig. 1). Like the ASP coreholes, these penetrated no deeper than $330 \mathrm{~m}$. Water depth at hole sites was as much as $300 \mathrm{~m}$.

Whereas Poag's emphasis is on analyses of drillhole samples, Schlee's emphasis is on the acoustic characteristics of seismic reflectors. Schlee describes the seismic units delineated on the seismic records and thereby provides an interpretation of the depositional environment in which the rocks they represent were formed. Schlee's approach allows him to interpret the stratigraphy and paleoecology of sequences below the bottom of the COST No. B-2 well (4,890 m below kelly bushing).

Grow and Klitgord (this volume), in an effort to interpret the structural framework of the Baltimore Canyon Trough area, have integrated the seismic-reflection data with the results obtained from seismic-refraction surveys, velocity computations, and gravity and magnetic surveys. Interpretations of the magnetic field (Grow and Klitgord, this volume) are based on data from a high- 
sensitivity aeromagnetic survey along $185,000 \mathrm{~km}$; the survey was flown and the data were compiled and contoured by LKB Resources, Inc.

The discussion of petroleum geology in this report is divided into four sections entitled: (1) General Comments; (2) COST No. B-2 Well; (3) Shelf; and (4) Slope. Analogies between the U.S. Atlantic margin and other offshore areas (producing and nonproducing) are discussed in the first section. In the second section, analyses of cuttings, cores, and logs from the COST No. B-2 well (the only deep well on the outer shelf in the Baltimore Canyon Trough from which data are available) provide information about lithology, depositional environments, organic-carbon contents and types, thermal maturity, reservoir rock character, and presence or absence of seals. Because much has been written already on the petroleum geology of the shelf, the third section is short and deals primarily with potential traps. Further discussions pertaining to the petroleum geology of the shelf can be found in Mattick and others (1974), Smith and others (1976), Scholle (1977b), and Schlee, Martin, and others (1977). In the fourth section, much of the discussion of the slope area is derived from geophysical data and is somewhat speculative. The authors attempt to draw preliminary conclusions concerning source rocks, reservoir rocks, and potential traps on the slope.

As often happens, authors of different parts of this report have some conflicting interpretations, some of which are based on the same data. Where such conflicts have arisen in this report, an attempt has been made to refer the reader to the alternative or conflicting interpretation(s) rather than to force an artificial conformity among the different sections. For example, Poag (this volume) places the Cretaceous-Jurassic boundary in the COST No. B-2 well at 4,060 m, whereas Bayer and Mattick (this volume) place the boundary below the basal section penetrated in this well. Bayer and Mattick follow Scholle (1977a, p. 8) who said, "Although the basal part of the section might well be Jurassic, the consensus now favors a Berriasian (Early Cretaceous) age ${ }^{* * *}$." According to E. I. Robbins (oral commun., 1977), however, dinoflagellates in a core at 4,060 $\mathrm{m}$ from the COST No. B-2 well indicate a Kimmeridgian (Late Jurassic) Age.

\section{ACKNOWLEDGMENTS}

We thank William P. Dillon and Thomas G. Gib- son for their editorial and technical advice in preparing the section on foraminiferal stratigraphy and paleoecology. Page C. Valentine, Raymond E. Hall, Charles C. Smith, Richard Benson, and William H. Abbott contributed biostratigraphic analyses, and William H. Abbott provided the paleoecologic interpretations of diatom assemblages. We gratefully acknowledge technical assistance from the following USGS personnel: Peter K. Stinger, Frederick N. Zihlman, and Patricia L. Brady for compiling velocity data and maps and Lois Tomlinson for her meticulous work in preparing and correcting many of the figures.

\section{PROCESSING OF SEISMIC DATA}

\section{By Robert C. Anderson, William C. Patterson, and RICHARD WISE ${ }^{1}$}

The location of the seismic profiles discussed in this volume are shown in figure 1 . These profiles were recorded by Digicon Geophysical Corporation under USGS contract in the years 1973 through 1976. Profiles 2 and 3 were processed by Digicon Geophysical Corporation, profiles 6, 9, and 10 were processed by Geophysical Services, Inc., and 11 and 12 were processed by the USGS. Final processing for profile 13 has not been completed.

A flow chart of the first-pass processing procedures performed by the USGS is shown in figure 2. Those performed by contract service companies were similar. Processing begins with demultiplexing of field records, that is, sorting the data into a format compatible with specific computer requirements. Correction for signal-amplitude decay is made in the demultiplexing phase by applying a gain function, usually an exponential curve. The gain curve is designed to correct for the average attenuation of amplitude while preserving the short-period variations caused by changes in the subsurface acoustic contrasts. In this phase of processing, trace editing is performed to remove erroneous data.

Data Analysis (fig. 2) is usually performed several times along a profile. Processing parameters are rechecked and altered if necessary to account for changes in conditions near the shotpoint. For many profiles, the data analysis provides additional information to the interpreter

\footnotetext{
${ }^{1}$ Digicon Geophysical Corporation, Houston, Texas
} 


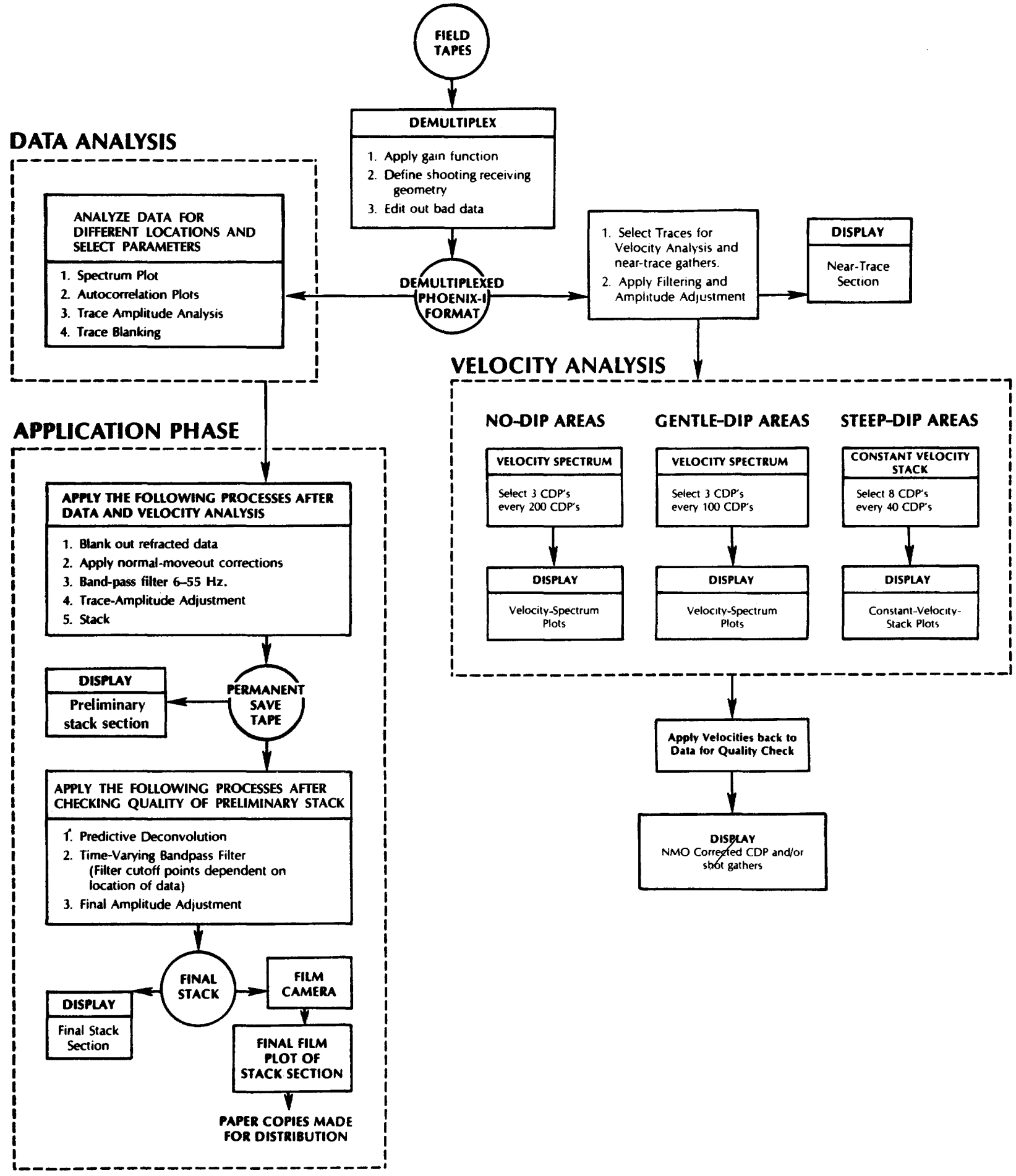

FIGURE 2. - Flow chart of the first-pass processing steps performed by the USGS on the multichannel seismic-reflection profiles 11, 12 , and 13 (fig. 1). Designations used: CDP, common depth point; NMO, normal moveout. 
such as correlation between frequency content of a reflection and geologic characteristics.

The velocity-analysis phase (fig. 2) is important because the velocities used in computer computations greatly affect the quality of final seismic records. Velocities derived in this phase are used to compute normal-moveout (NMO) corrections prior to stacking. Stacking, or summing, the commondepth-point (CDP) traces increases the signal-tonoise ratio of the subsurface reflections so they can be mapped more easily.

The two boxes on the flow chart (fig. 2) labeled "velocity spectrum" represent methods for deriving stacking velocities. Both methods involve scanning the reflection hyperbola and plotting reflection coherence as a function of velocity and time. In areas of steep dip, a constant velocity stack is used; the procedure consists of stacking a short segment of the data at various constant velocities and then visually choosing the velocity that best corrects the data at the different times.

In the application phase, the data are stacked and predictive deconvolution filtering and bandpass filtering are applied. Predictive deconvolution is a procedure for attenuating water-bottom multiples, which can interfere with primary reflections. Water-bottom multiples result from energy being trapped between the air-water interface and the water-sediment interface. Reverberation removal has been very successful for lines on the shelf where the water is shallow. In deeper water (greater than $500 \mathrm{~m}$ ), predictive deconvolution is less effective, and other methods have been devised by the USGS to attack this problem. The most effeetive method to date has been to weigh (on the basis of wave amplitude) the individual traces prior to stacking to enhance the NMO discrimination of multiple reflections during the stacking process.

Finally, a band-pass filter and a final amplitude adjustment are applied to the data before the final display. The resulting section is an amplitude-and frequency-balanced seismic time section showing geologic information that has been separated from seismic noise. Relative amplitude changes have been preserved on the section to allow interpretation of amplitude information; in recent years, amplitude information has been used to locate changes in rock composition, porosity, and layer thickness and to identify contained fluid.

Special processing was performed on lines 2, 3, and 9 by Digicon Geophysical Corporation to improve the continuity of reflectors, both shallow and deep. This processing involved computing velocity analyses every $1.6 \mathrm{~km}$ or every $0.8 \mathrm{~km}$ where structural changes were detected, and computing a better deconvolution operator and filter. Final rootmean-square velocities were contoured and reevaluated to provide the best functions for stacking the data. Final stacked data were then migrated to put the data in a more realistic attitude. The final process was converting these time data to depth.

\section{GEOLOGIC SETTING}

By Kenneth C. Bayer and Robert E. Mattick

The lease tracts for proposed Lease Sale No. 49 (fig. 1) are within the Baltimore Canyon Trough, an elongate northeast-trending sedimentary basin that was named by Maher (1965) for a nearby submarine canyon. The trough extends more than 600 $\mathrm{km}$ between Long Island and Cape Hatteras and is arcuate but subparallel to the shoreline. It is widest $(200 \mathrm{~km})$ off New Jersey, where its sediment fill is thickest-14 km (Mattick and others, 1974; Schlee, Martin, and others, 1977).

The geology of the Baltimore Canyon Trough is characterized by extensional tectonic features, a result of the splitting apart of an older supercontinent into the North American and African continents during the Mesozoic Era. In general, extensional margins or Atlantic-type margins are structurally simple in relation to their postrift sedimentary sequences.

A diagrammatic cross section of the Baltimore Canyon Trough is shown in figure 3. Sheridan (1976, p. 118-120) listed 14 geologic features of offshore basins on the North American margin. Several of the features listed by Sheridan (1976) and additional ones, as interpreted by us, are described as follows:

1. Breakup of basement into horst and graben structures during initial phases of rifting, probably during Triassic time: The westerly dip of faults beneath the slope and shelf edge suggests that continental breakup began beneath the midshelf area. Later, when rifting actually took place, the locus of the rift shifted eastward to a position at, or somewhat east of, the base of the present Continental Slope. 


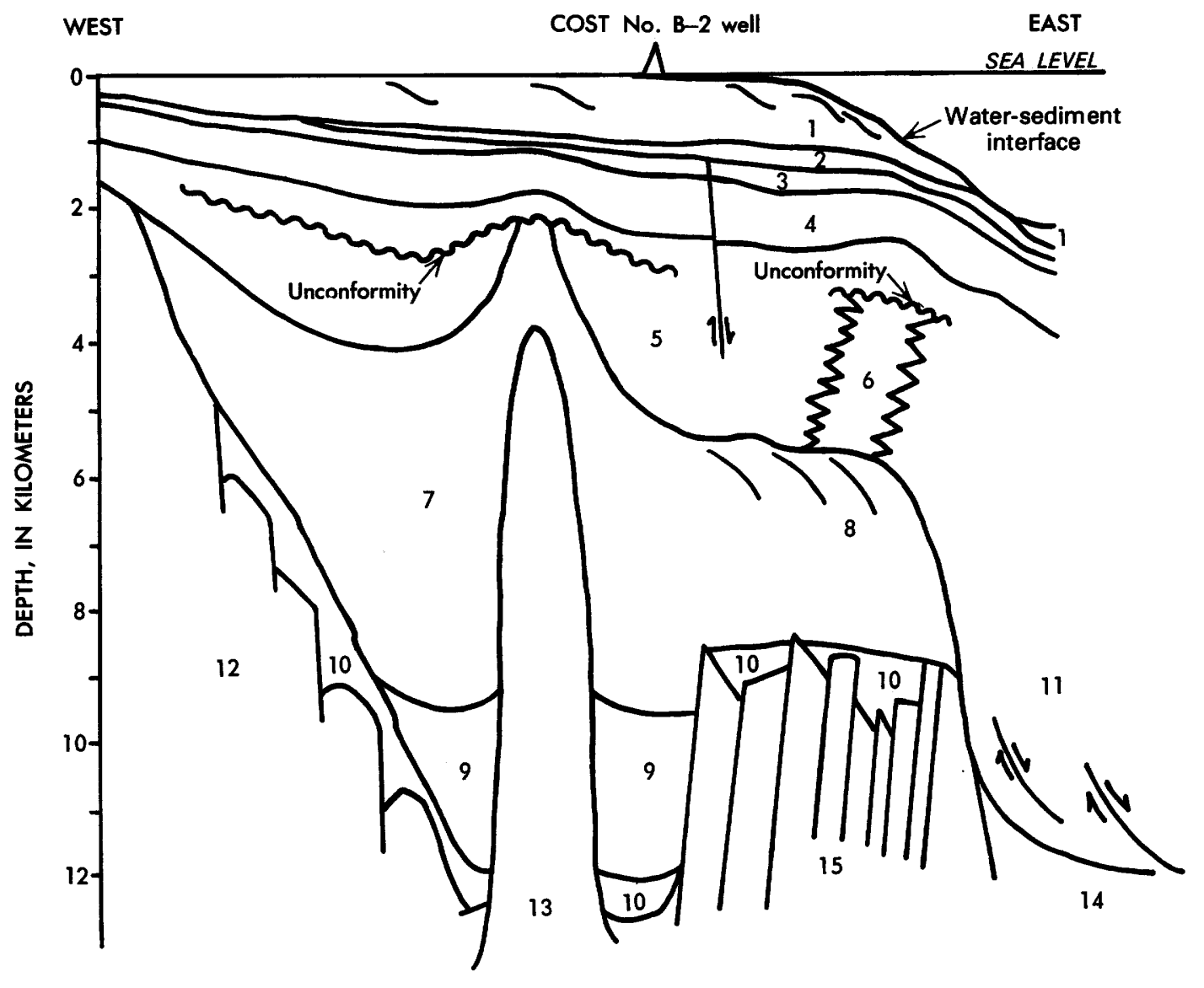

EXPLANATION

1. Pleistocene, Pliocene, and Miocene shallow marine to nonmarine deposits; chiefly unconsolidated sand containing shale in the basal part of the section.

2. Oligocene marine shale and claystone that pinches out shoreward.

3. Eocene and Paleocene marine deposits; chiefly dense argillaceous micrite and claystone.

4. Upper Cretaceous deposits; chiefly marine sandstone and shale.

5. Lower Cretaceous sedimentary rocks; chiefly alternating sandstones and shales of shallow marine to nonmarine origin; contains coal and lignite seams; grades into limestone at shelf margin.

6. Lower Cretaceous shelf-edge reef.

7. Jurassic sedimentary rocks; by analogy with Scotian Shelf, upper part consists chiefly of sandstone and shale, lower part consists chiefly of limestone.

8. Jurassic carbonate bank deposit.

9. Jurassic salt and evaporite deposits.

10. Triassic deposits; chiefly continental lake and stream deposits.

11. Slope deposits.

12. Continental basement rocks.

13. Mafic intrusion (Great Stone dome).

14. Oceanic basement rocks.

15. Basement rocks (?), uplifted and block faulted.

FIGURE 3.-Diagrammatic cross section of the Baltimore Canyon Trough. Approximate length of section is $200 \mathrm{~km}$. 
2. Deposition in grabens of Triassic nonmarine red beds, mudstone, shale, siltstone, arkosic sandstone, and fanglomerate: In outcrops onshore, these rocks are a heterogeneous mixture of stream, lake, and swamp deposits plus intrusive and extrusive volcanic rocks.

3. Great subsidence of basement rocks to depths of 12-14 km since Triassic or perhaps Early Jurassic time: The subsidence is believed to be the result of cooling (Sclater and others, 1971) and an associated increase in density of the deep crustal rocks. A controversy exists over how much rocks subsided at the present shelf edge. Some authors (Schlee and others, 1976; Sheridan, 1976) believe that basement rocks are at a depth of $12-14 \mathrm{~km}$ beneath the shelf edge in the Baltimore Canyon Trough area. Other authors (Mattick and others, 1974) believe that the shelf edge is underlain by a high-standing basement ridge (6-7 km deep), behind which Jurassic sediments accumulated. On the basis of magnetic studies, Grow and Klitgord (this volume) believe that the shelf edge is underlain by an uptilted block of oceanic crust at a minimum depth of 6-8 km.

4. Deposition of evaporite beds in a narrow, shallow early Atlantic sea: Although this part of the section probably contains salt, authors differ in their opinions on whether or not a significant amount of salt flowed in the Baltimore Canyon Trough area; compare the opinions in this report of Poag, of Grow and Klitgord, and of Mattick and Girard.

5. Thick accumulations of carbonate rocks in the Jurassic.

6. Formation of Jurassic carbonate bank complexes under what is now the Continental Slope and edge of the Continental Shelf: The carbonate bank deposits may have formed above a basement ridge.

7. Thick accumulations of Upper Jurassic through Oligocene sand and shale and subordinate amounts of limestone, coal, and lignite: This part of the section is primarily nonmarine to very shallow marine in origin.

8. Reef growth along the then-existing shelf edge (under the present slope) in Late Jurassic and Early Cretaceous time. During Early Cretaceous time, the reef was exposed or nearly exposed and later, in Late Cretaceous time, it was buried by an influx of deltaic sediments.
9. Intrusive igneous doming during the last stages of the Early Cretaceous.

10. Outward building of the Continental Shelf by progradation in the Miocene.

Structure-contour and isopach maps on strong seismic-reflecting horizons are shown in figures 4-8. Data from onshore wells and the COST No. B-2 well provided correlation for the seismic interpretation. The authors have more confidence in the seismic results from the Continental Shelf than in those from the slope and rise. We were able to tie together, by means of line 12 (fig. 1), the seismic profiles on the shelf. The strike profile across the rise (line 13, fig. 1), however, was not available. Some evidence exists for faulting, generally on the shelf margin and the Continental Slope, but because of the map scales, faulting is ignored.

\section{STRUCTURAL FRAMEWORK}

\section{By John A. Grow and Kim D. Klitgord}

Our knowledge of the structural framework of the Outer Continental Shelf, Slope, and Rise depends primarily on four types of geophysical measurements: seismic refraction, seismic reflection, magnetic, and gravity. In this section, we review these basic data in order to define the major structural elements in the area of Lease Sale No. 49 and infer their geologic evolution.

\section{SEISMIC-REFRACTION DATA}

Three early series of refraction surveys (fig. 9) were conducted off New York and New Jersey (Ewing and others, 1950; Drake and others, 1959; Ewing and Ewing, 1959). Analysis of these data indicated $5 \mathrm{~km}$ of low-velocity (less than $4.5 \mathrm{~km} / \mathrm{s}$ ) sedimentary rocks in the midshelf area. The lowvelocity layers are underlain by refracting layers having velocities greater than $5.3 \mathrm{~km} / \mathrm{s}$. Because velocities above $5.3 \mathrm{~km} / \mathrm{s}$ correlated with basement rocks onshore, these higher velocity layers were also believed to represent basement rocks in the midshelf and outer-shelf areas (stations 85 and 86; Drake and others, 1959). However, on the basis of subsequent reflection studies, authors of later papers interpreted these high velocities as representing carbonate rocks in the midshelf area and carbonate bank deposits or reef complexes in 


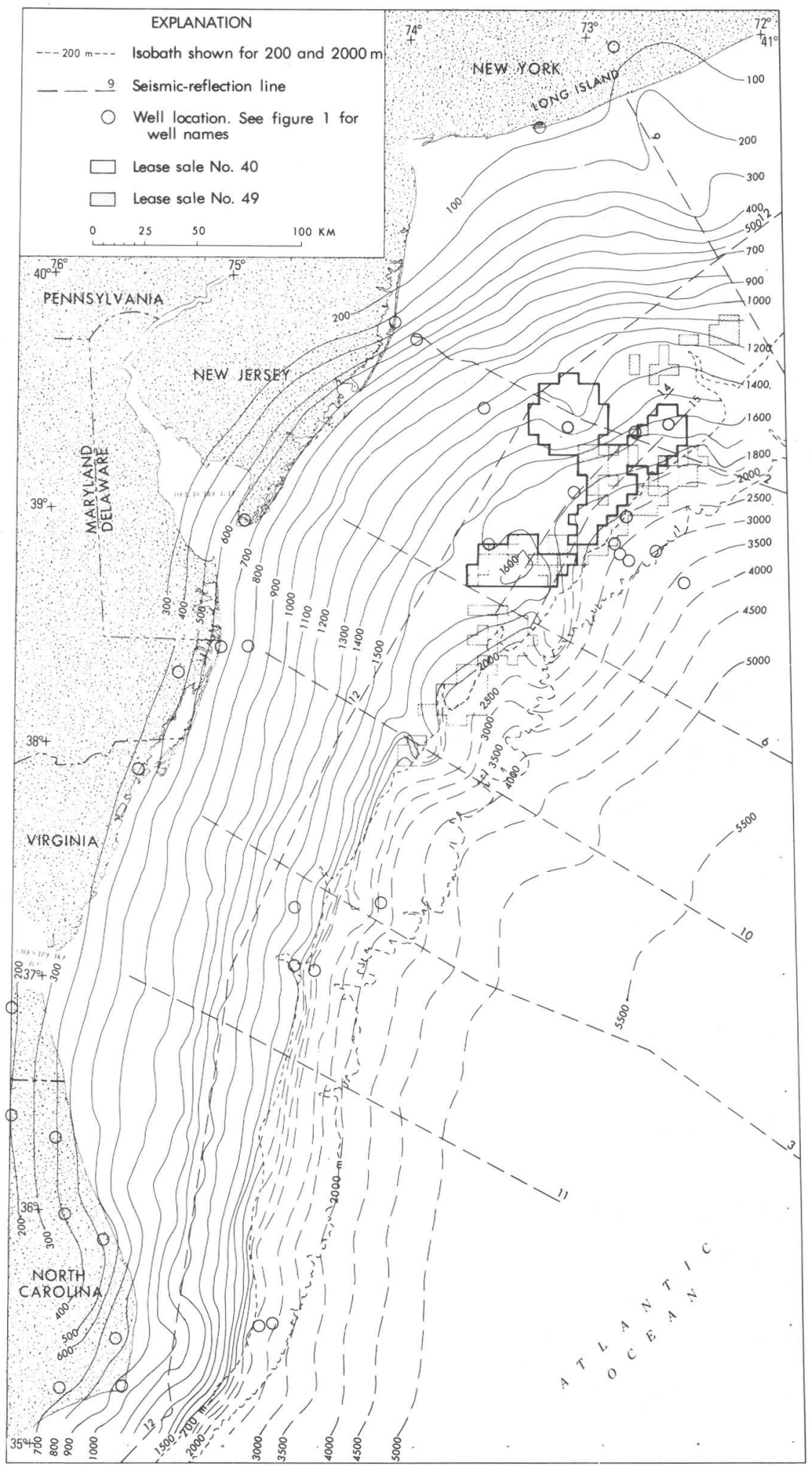

FIGURE 4. -Structure-contour map of the mid-Atlantic continental margin of the United States showing depth in meters to the top of Upper Cretaceous rocks. Datum is mean sea level. Contour interval is $100 \mathrm{~m}$ on the shelf and $500 \mathrm{~m}$ on the slope and rise. Dashed contours indicate data subject to change. 


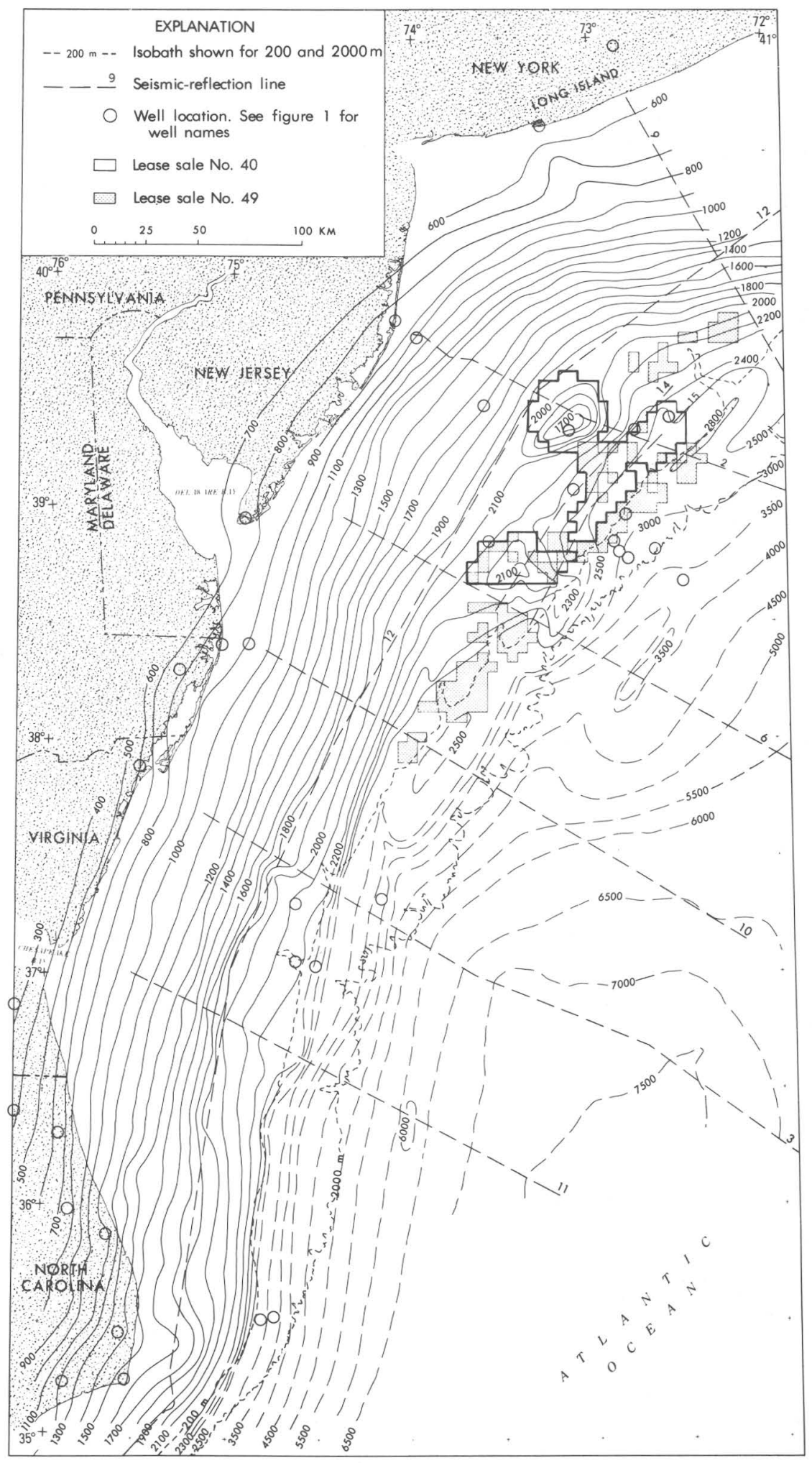

FIGURE 5.-Structure-contour map of the mid-Atlantic continental margin of the United States showing depth in meters to the top of Lower Cretaceous rocks. Datum is mean sea level. Contour interval is $100 \mathrm{~m}$ between water depths of 300 and $2,500 \mathrm{~m}$ and is $500 \mathrm{~m}$ in water depths greater than $2,500 \mathrm{~m}$. Dashed contours indicate data subject to change. 


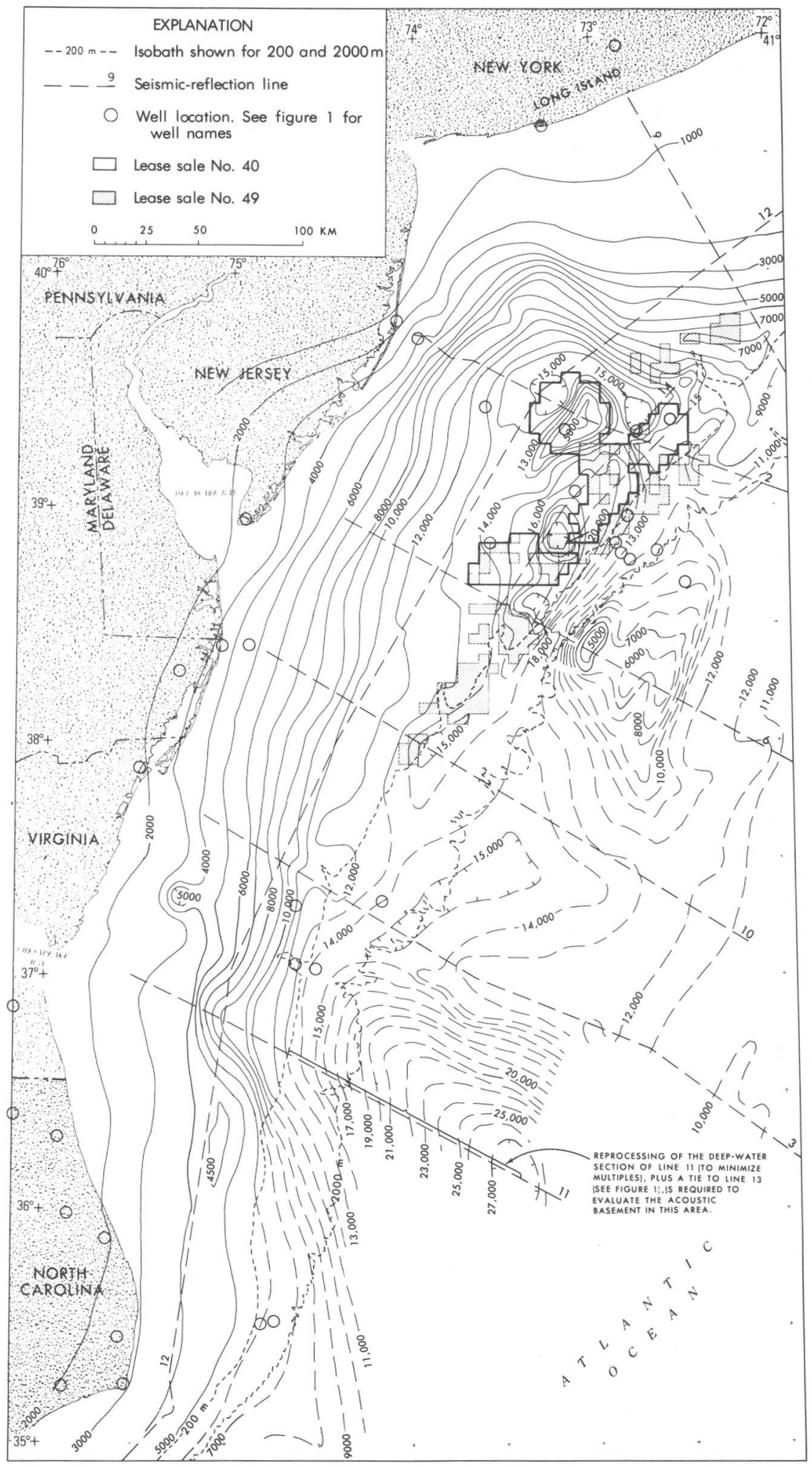

FIGURE 6. - Structure-contour map of the mid-Atlantic continental margin of the United States showing depth in meters to the top of the acoustic basement. Datum is mean sea level. Contour interval is $1,000 \mathrm{~m}$, except along part of seismicreflection line 2 where the interval is $2,000 \mathrm{~m}$. Dashed contours indicate data subject to change. 


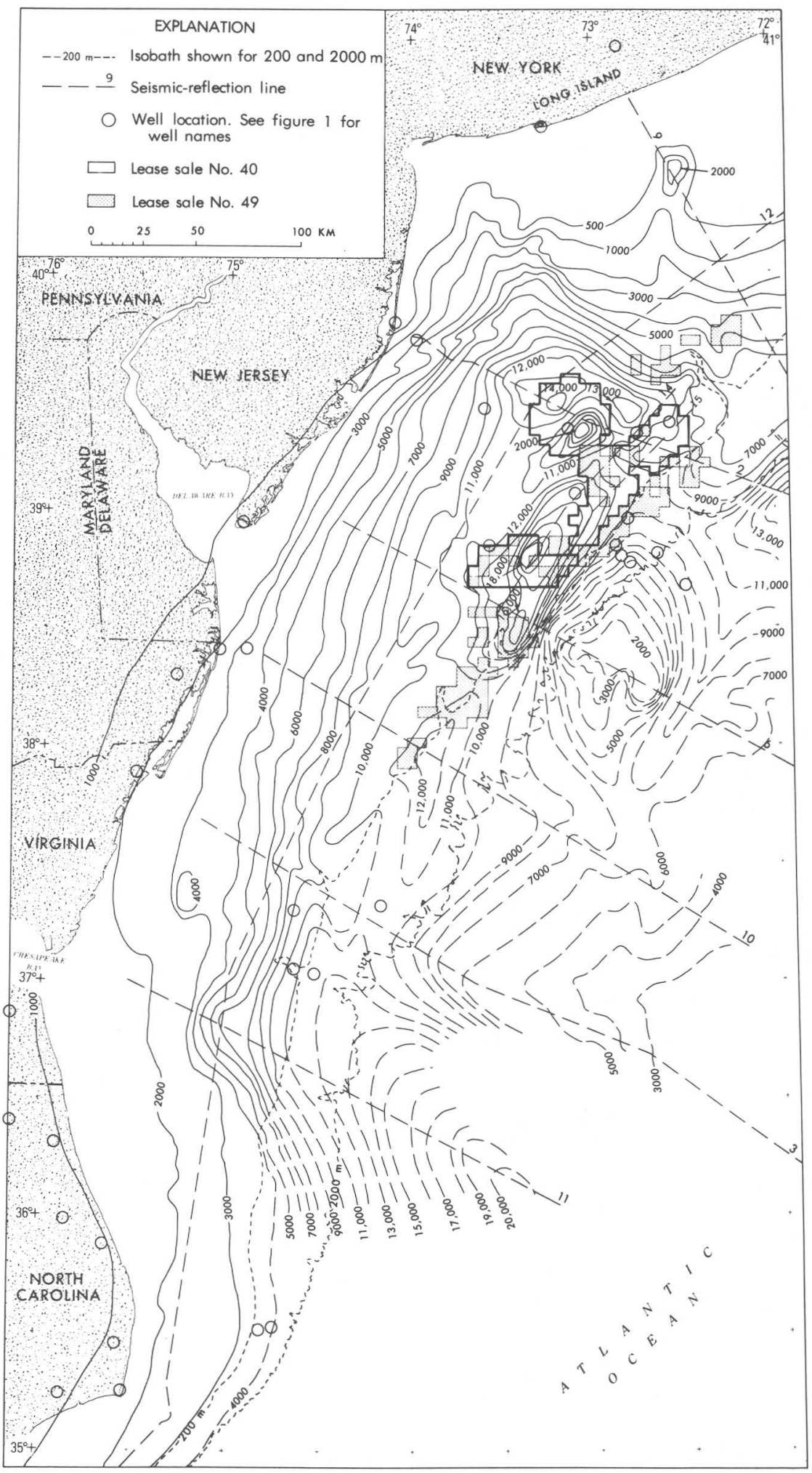

FiguRE 7.-Isopach map of the mid-Atlantic continental margin of the United States showing thickness of Lower Cretaceous and older sedimentary rocks above the acoustic basement. Contour interval is $1,000 \mathrm{~m}$, except along part of seismic-reflection line 2 where the interval is $2,000 \mathrm{~m}$. Dashed contours indicate data subject to change. 


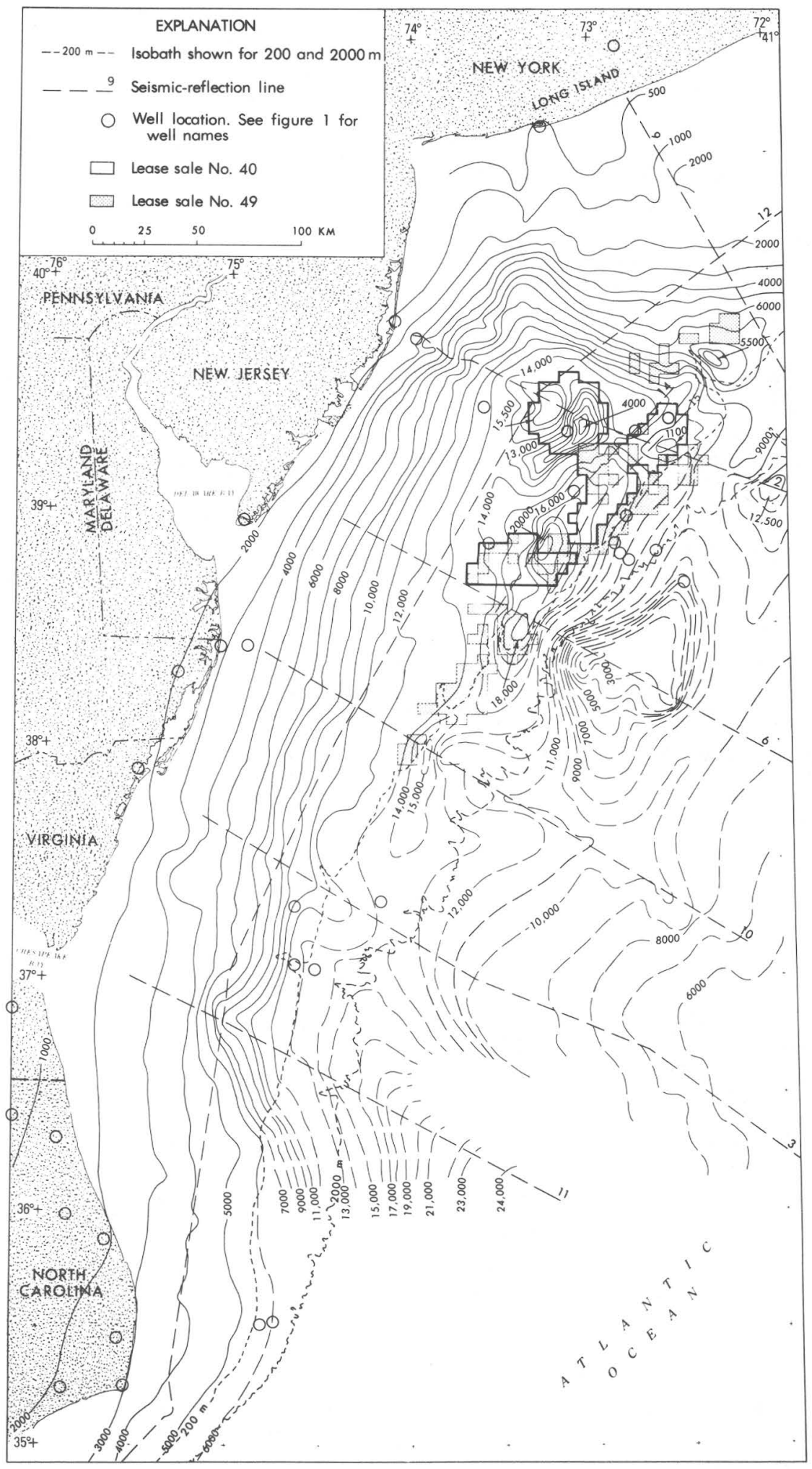

FIgURE 8.-Isopach map of the mid-Atlantic continental margin of the United States showing total sediment thickness between the sea floor and the acoustic basement. Contour interval is $1,000 \mathrm{~m}$, except along part of seismic-reflection line 2 where the interval is $2,000 \mathrm{~m}$. Dashed contours indicate data subject to change. 


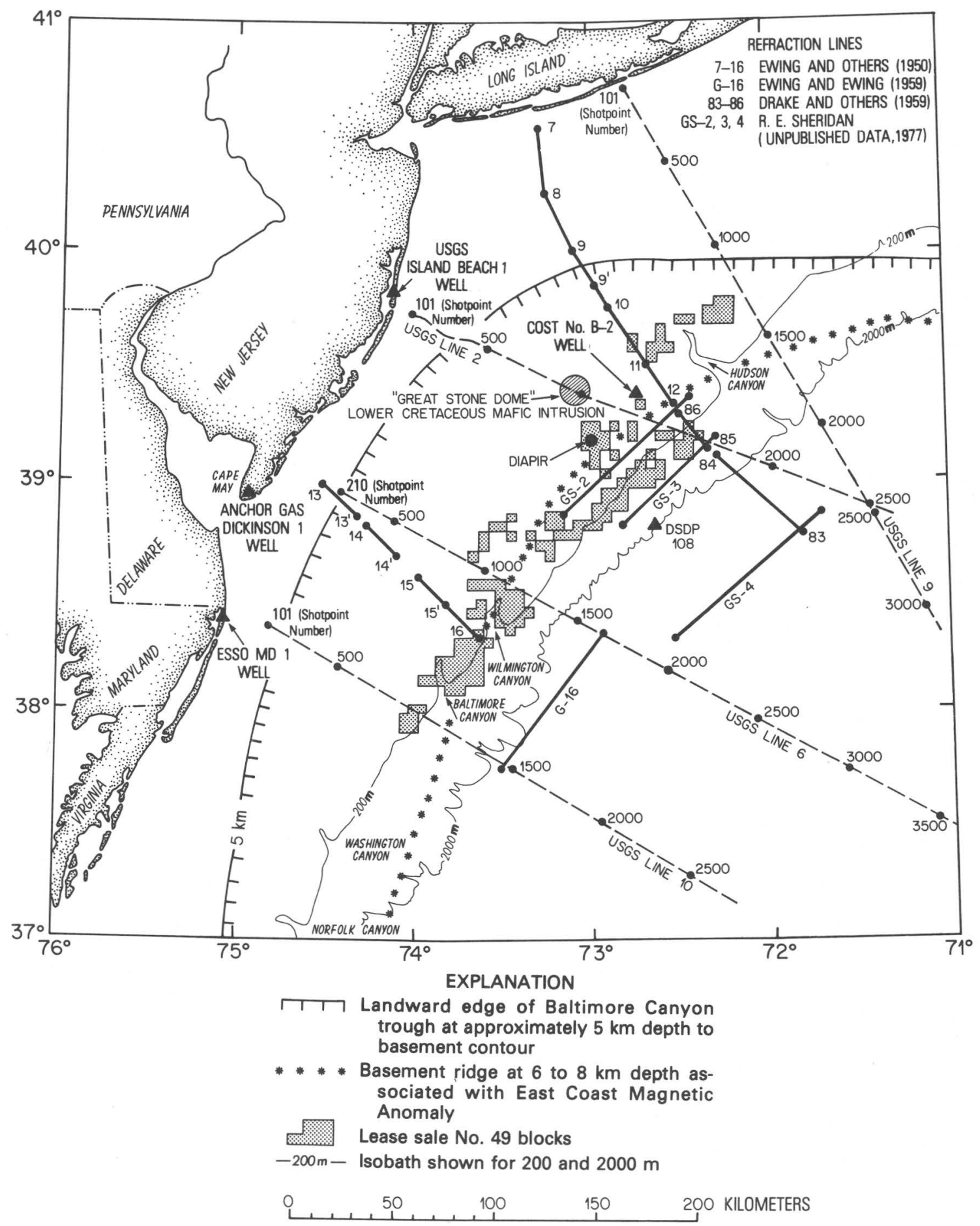

FIgURE 9.-Map showing locations of seismic-refraction surveys discussed in text. The locations of some of the CDP multichannel seismic-reflection lines (fig. 1) are also shown (dashed lines) for reference. 


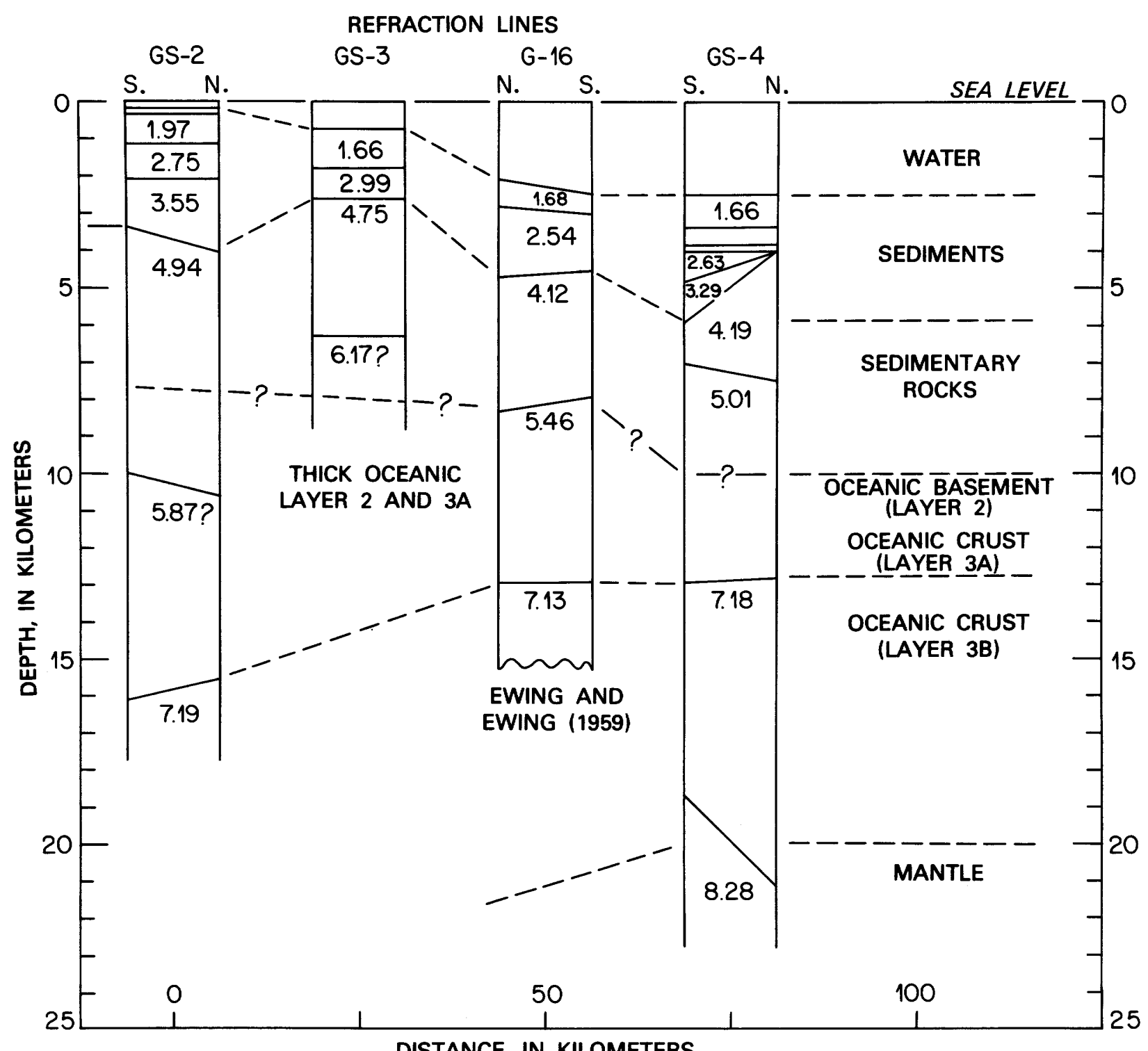

FiguRe 10. - Cross section from outer shelf to rise based on recent seismic-refraction surveys (R. E. Sheridan, unpub. data, 1977). Velocities are shown in kilometers per second. See figure 9 for locations of sections GS-2, 3, and 4 and G-16.

the outer shelf area (Emery and Uchupi, 1972; Sheridan, 1974; Mattick and others, 1974; Mattick and others, 1977; Schlee and others, 1976; Schlee, Behrendt and others, 1977; Grow and others, 1979).

Three recent refraction lines (GS-2, GS-3, and GS-4) are near the intersection of the earlier refraction work and CDP line 2 (fig. 9). The results from the analysis of these lines confirm earlier interpretations of stations 83-84 and 85-86 by Drake, Ewing, and Sutton (1959) and extend the $7.13-\mathrm{km} / \mathrm{s}$ horizon reported by Ewing and Ewing
(1959) at profile G-16 (fig. 10). This layer has velocities of $7.13-7.19 \mathrm{~km} / \mathrm{s}$ (fig. 10) and is inferred to represent oceanic crustal layer $3 \mathrm{~B}$ as defined by Sutton, Maynard, and Hussong (1971). Because reflection data along CDP line 2 near GS-4 (figs. 11,12 ) indicate that sediments extend to a depth of more than $9 \mathrm{~km}$, the $5.01-\mathrm{km} / \mathrm{s}$ refractor at GS-4 must represent a high-velocity sedimentary horizon on the Continental Slope. Refracted arrivals from oceanic basement (layer 2 having velocities between 5.46 and $6.5 \mathrm{~km} / \mathrm{s}$ ) and oceanic crust (layer 3A having velocities between 6.5 and 



FIGURE 11. - Line drawings showing strong reflectors, interval velocities, and inferred ages of horizons interpreted from seismicreflection profiles. $A$, Profile 9. $B$, Profile 10. $C$, Profile 6. $D$, Profile 2. Locations of profiles are shown in figures 1 and 9. Velocities of the units (between dashed vertical lines) are shown in kilometers per second, and the mean standard deviation is shown by \pm . Designations used: T, Tertiary; UK, Upper Cretaceous; LK, Lower Cretaceous; A, strong seismic reflector mappable throughout the Atlantic basin. The Lower Cretaceous mafic intrusion is called the Great Stone dome. Reflectors are dashed where inferred.

$7.0 \mathrm{~km} / \mathrm{s}$ ) apparently were not recorded at GS-4. Perhaps arrivals from a deeper $7.18-\mathrm{km} / \mathrm{s}$ layer masked the arrivals from layers 2 and $3 \mathrm{~A}$. A mantle velocity of $8.28 \mathrm{~km} / \mathrm{s}$ was also detected at GS-4 at a depth of about $20 \mathrm{~km}$.

The refraction data support the following conclusions:
1. Along the inner shelf, the shallow $5.3-6.0-\mathrm{km} / \mathrm{s}$ refractors represent continental basement rock.

2. Along the midshelf to outer shelf and upper slope, between the depths of 2.6 and $6.0 \mathrm{~km}$, the $4.8-5.7-\mathrm{km} / \mathrm{s}$ refractors represent Lower Cretaceous and Upper Jurassic carbonate rocks. 


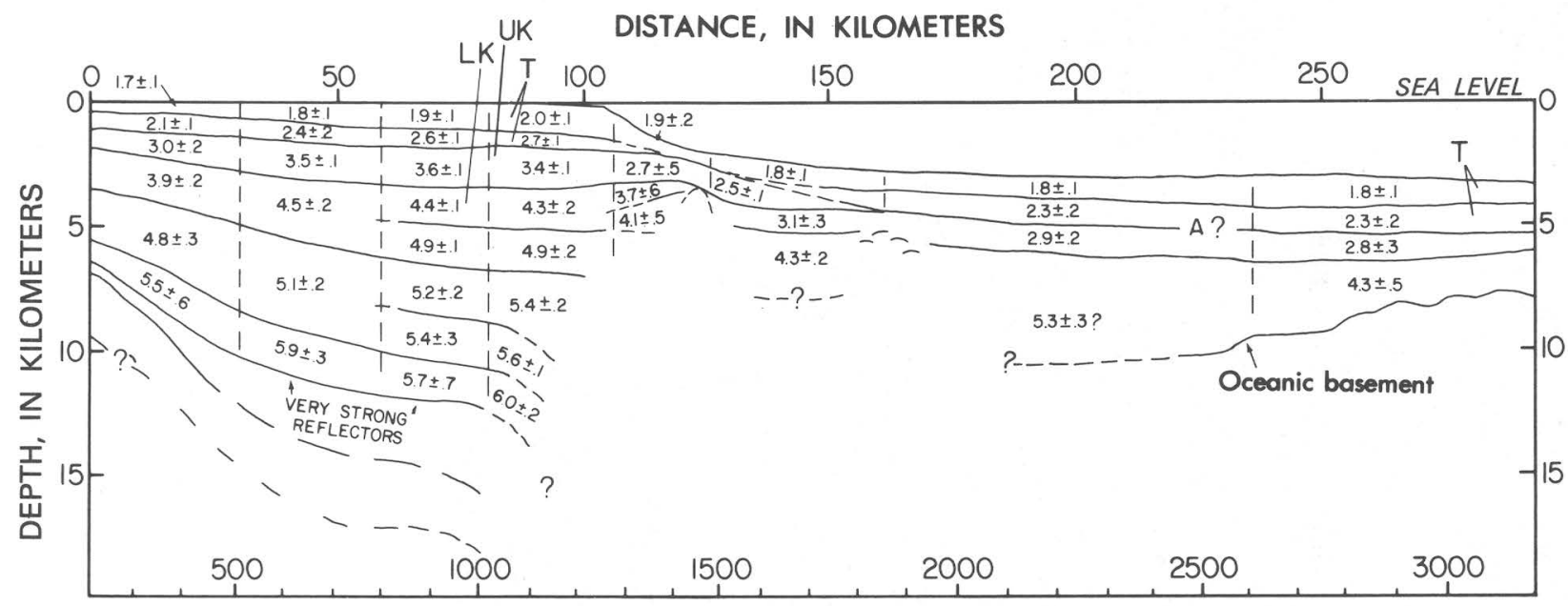

SHOTPOINT NUMBER

C

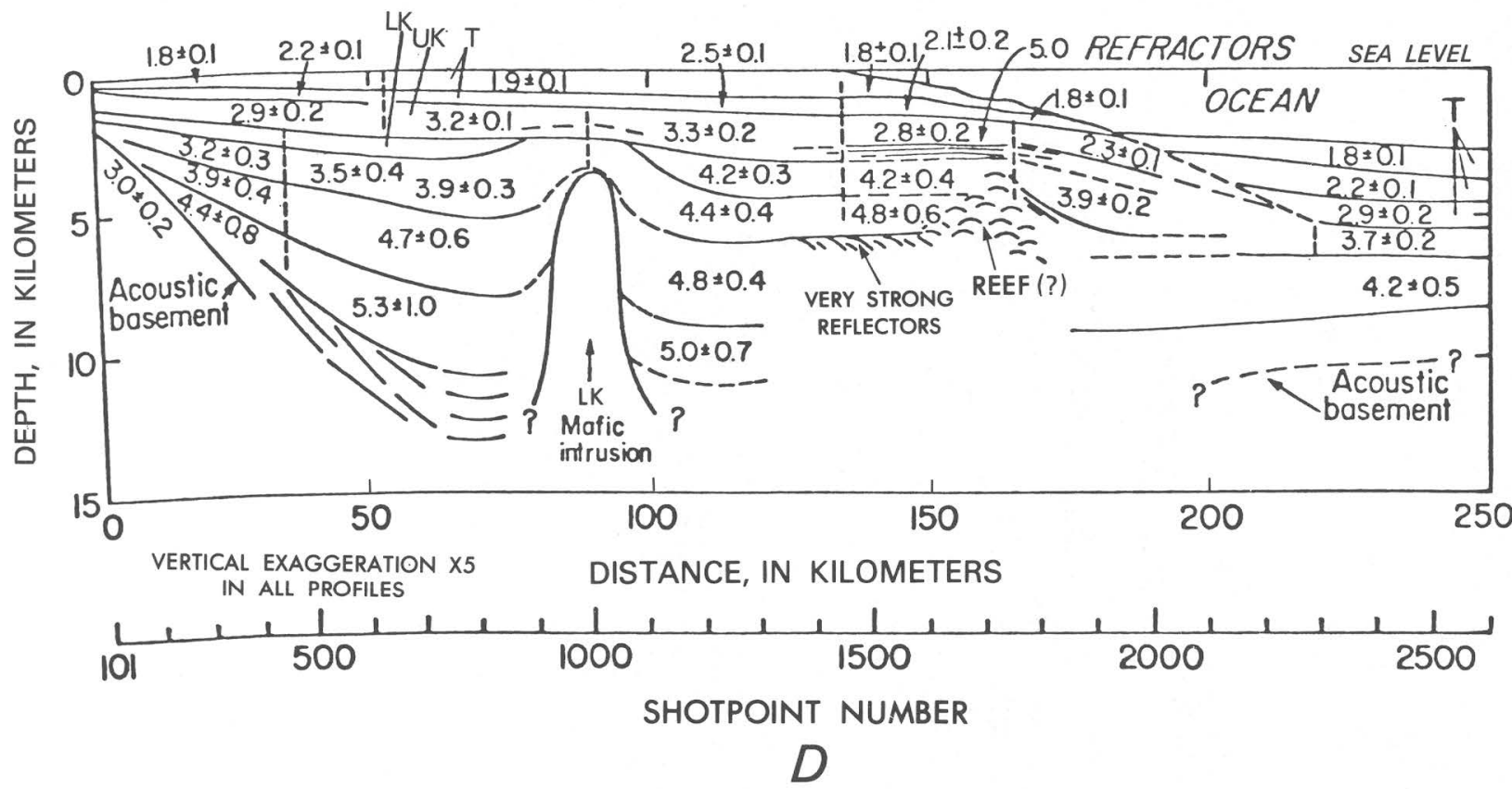

Figure 11.-Continued

3. Oceanic crustal layer $3 \mathrm{~B}$ having a velocity of $7.13-7.19 \mathrm{~km} / \mathrm{s}$ dips gently landward and can be traced to a depth of about $15 \mathrm{~km}$ beneath the outer edge of the Continental Shelf.

4. The top of oceanic basement (layer 2) cannot be clearly defined near refraction lines GS-2, GS-3, and GS-4.
5. The $5.87-$ and $6.17-\mathrm{km} / \mathrm{s}$ arrivals on lines GS-2 and GS-3 are poorly defined arrivals, and we do not know whether they represent highvelocity sedimentary rocks or basement rocks.

6. High velocities, indicative of basement rocks, have not been measured by seismic-refraction surveys in the central Baltimore Canyon Trough area. 


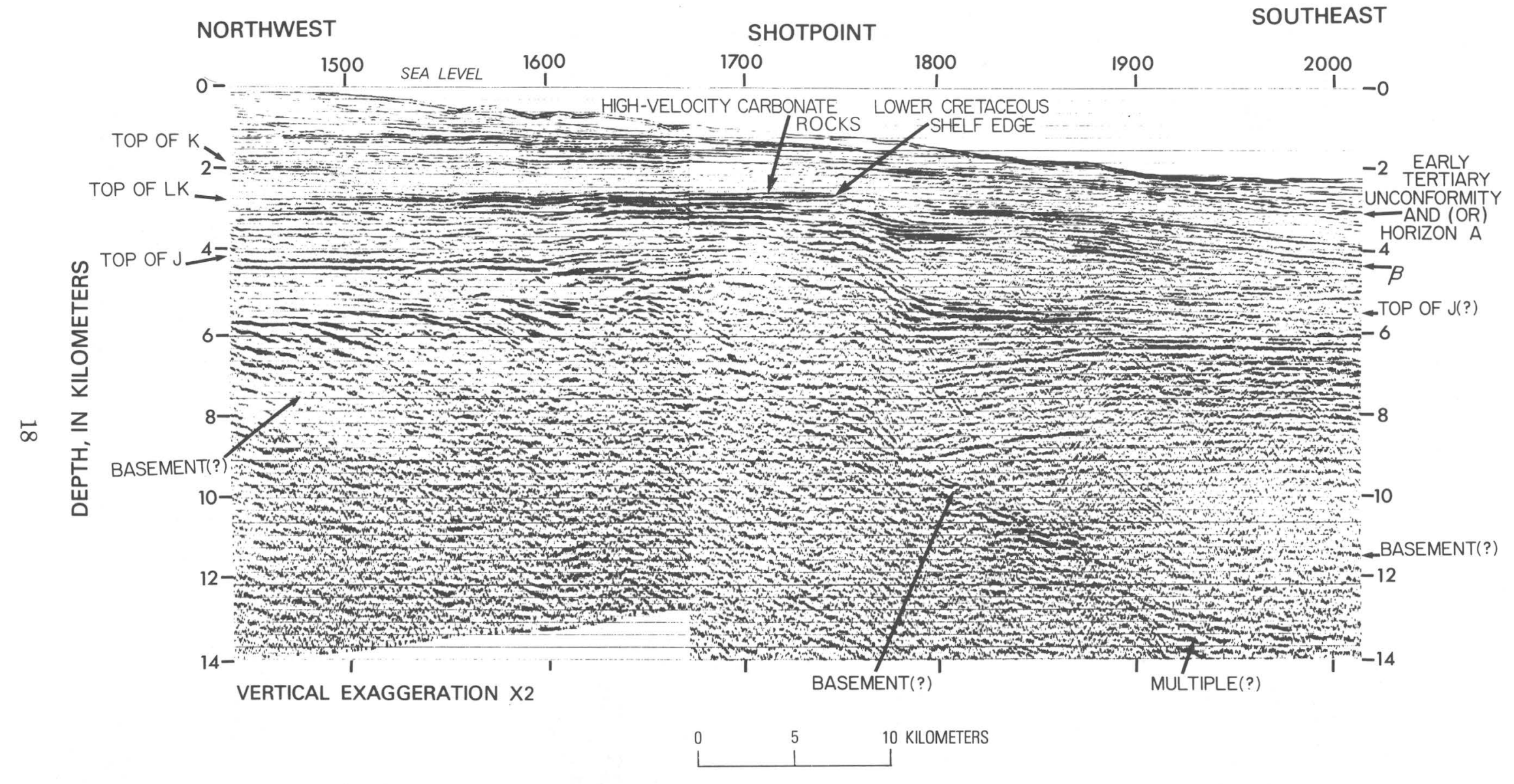

FIGURE 12. - Part of CDP multichannel seismic profile 2 having vertical scale in depth. Location of profile 2 is shown in figures 1 and 9 . Designations used: LK, Lower Cretaceous; K, Cretaceous; J, Jurassic; A and $\beta$, strong seismic reflectors mappable throughout the Atlantic basin. 


\section{MULTICHANNEL SEISMIC-REFLECTION DATA}

The seismic-reflection data from the Baltimore Canyon Trough area (lines 2, 6, 9, and 10; see figs. 1 and 9 for location) are summarized in figure 11. Lines 2, 6, and 10 reveal two major sedimentary troughs; one beneath the shelf contains at least 12 $\mathrm{km}$ of sedimentary rocks, and a second is beneath the upper Continental Rise where the sedimentary rocks are at least 9 or $10 \mathrm{~km}$ thick. The shelf and rise sediment troughs are separated by an acoustically opaque feature interpreted to be a ridge whose top ranges from 3 to $6 \mathrm{~km}$ below sea level.

The parts of the four profiles over the outer shelf edge and upper Continental Slope near the possible ridge were converted from two-way travel time to depth below sea level (figs. 12-15). Both the time and depth sections are shown for line 6 (fig. 13). The strong reflector at a depth of about $3 \mathrm{~km}$ beneath the shelf edge apparently represents the top of the Lower Cretaceous section. The diffraction pattern at a depth of $3.5 \mathrm{~km}$ near shotpoint 1480 is probably associated with the edge of the Lower Cretaceous shelf. A major unconformity is beneath the present upper rise, where Tertiary rise sediments overlie the Lower Cretaceous shelf margin (fig. 13). The present shelf edge appears to be about $20 \mathrm{~km}$ landward of the Lower Cretaceous shelf edge. The seismic record suggests that block faulting and arching of Lower Cretaceous horizons between shotpoints 1380 and 1500 took place near the end of Early Cretaceous time.

At a depth of $12 \mathrm{~km}$ beneath the shelf, the depth section for line 10 (fig. 14) shows a series of strong reflections that may represent basement rocks. Alternatively, its smooth continuous character between shotpoints 800 and 950 suggests that it represents sedimentary units that may contain alternating evaporite and carbonate sequences (see Schlee, this volume). The apparent seaward dip of these deep reflectors between shotpoints 950 and 1000 may not be real but rather may result from diffraction. The top of Lower Cretaceous strata along line 10 is also marked by a strong reflection at about $3 \mathrm{~km}$ depth, and a rotated fault block can be seen on the seismic record (fig. 14) between shotpoints 1130 and 1200 . Beneath the Continental Rise (between shotpoints 1100 and 1300), a marked unconformity is present, and coherent reflections are absent at depths greater than $6 \mathrm{~km}$.
On line 2 (fig. 12), reflectors of unusually high amplitude appear at a depth of 2.6 to $4.0 \mathrm{~km}$ between shotpoints 1500 and 1700 . The lowest of these reflectors correlates with the top of the Lower Cretaceous section in the COST No. B-2 well. Although refraction velocities for this unit range from 4.8 to $5.3 \mathrm{~km} / \mathrm{s}$, the interval velocity, as calculated from reflection records, averages about $4.2 \mathrm{~km} / \mathrm{s}$ (fig. 11). This difference in velocity as measured by the two different seismic methods could indicate an alternating sequence of high- and low-velocity beds - the high velocities representing carbonate units and the low velocities representing sands and shales. The irregular reflectors at depths of 3-6 km at shotpoint 1750 (fig. 12) apparently represent a reef complex of Early Cretaceous and Late Jurassic age (Schlee and others, 1976; Mattick and others, 1977; Grow and others, 1979). The landward-dipping reflectors (fig. 12) at depths of $8-10 \mathrm{~km}$ between shotpoints 1800 and 2000 probably represent Jurassic turbidite deposits. The dip reversal could have resulted from differential subsidence rates between the shelf and the rise areas. The early shelf sediments have apparently subsided at least $12 \mathrm{~km}$, whereas the early rise sediments (probably deposited in 2-4 $\mathrm{km}$ of water) may have subsided only $6 \mathrm{~km}$. (Compare this interpretation for the dip reversal with the interpretation involving growth faults by Mattick, Scholle, and Girard (this volume).) The absence of coherent reflectors deeper than $6 \mathrm{~km}$ and the presence of magnetic sources between 7 and $8 \mathrm{~km}$ depth (see "Magnetic Data," this section) could be explained by a highstanding block of oceanic basement rock, a volcanic ridge, or a faulted sedimentary complex pervaded by mafic dikes and sills (during the Early Cretaceous?). The magnetic data suggest that the explanation involving oceanic basement rocks is the most likely.

The depth section for line 9 (fig. 15) indicates that the Lower Cretaceous shelf edge is at a depth of $3 \mathrm{~km}$ near shotpoint 1700 . Beneath the rise (shotpoint 1800), the strata appear to dip landward, as on line 2 . Some irregular reflections are from strata at 7-10 km depth beneath the shelf, but they appear much more broken up than on lines 2,6 , and 10 . We do not know whether the broken character of these deep units is typical of the area near line 9 or reflects poor data quality on this particular line. The change in character northward from line 2 to line 9 is probably due, in part, to the transition out of the main sediment trough beneath 


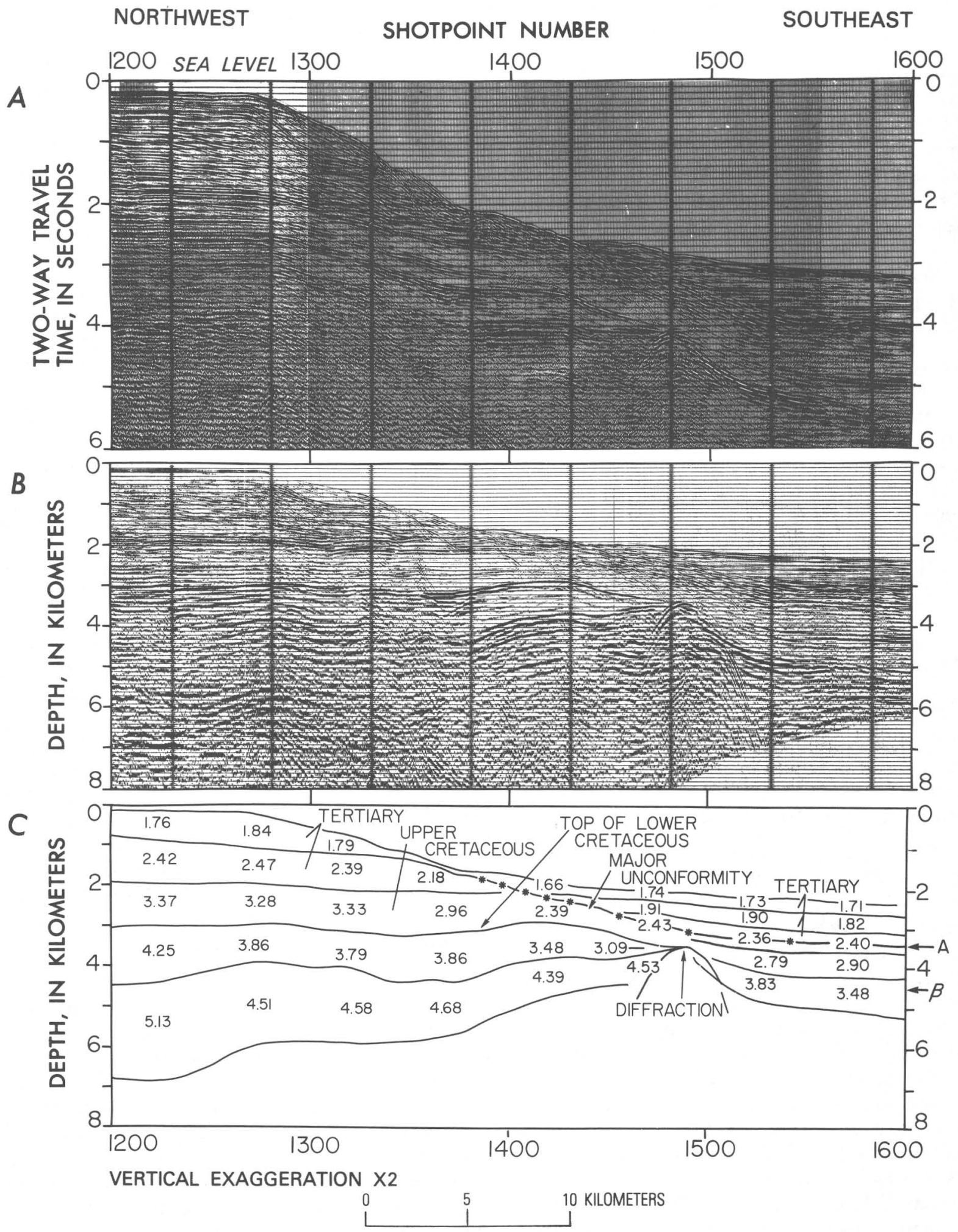

Figure 13.-Part of CDP multichannel seismic profile 6, which crosses the Continental Slope. Location of profile 6 is shown in figures 1 and 9. $A$, Seismic profile having vertical scale in two-way travel time. $B$, The seismic profile having vertical scale in depth. $C$, Section showing computed interval velocities (in kilometers per second) and inferred ages of horizons. Designation used: A and $\beta$, strong seismic reflectors mappable throughout the Atlantic basin. Segment of line marked by asterisks defines major unconformity. 
the New Jersey shelf up onto the Long Island platform, where a narrower and shallower trough is present along the outer shelf.

Velocities recorded in the COST No. B-2 well (Scholle, 1977b) are in good agreement with the interval velocities calculated from the seismic data in that vicinity (fig. 16). However, the $4.8-5.3-\mathrm{km} / \mathrm{s}$ refraction horizons detected at a depth of 2.6-3.9 $\mathrm{km}$ near stations GS-2, GS-3, and 85-86 (figs. 9, 10) can be traced on seismic sections to Albian and Aptian units penetrated in the COST No. B-2 well where lower velocities of $3.5-4.3 \mathrm{~km} / \mathrm{s}$ were measured. Our calculations, therefore, indicate that the velocities of the Albian and Aptian units increase southeastward from the COST No. B-2 well. This trend suggests a lateral change in facies. The presence of refraction velocities that are 10-15 percent faster than the interval velocities calculated from the reflection data is common along the U.S. Atlantic margin and may be explained by the alternation of high- and low-velocity beds as seen in the velocity logs from the COST No. B-2 well (fig. 16).

\section{MAGNETIC DATA}

Early aeromagnetic and shipboard magnetic data identified a conspicuous positive anomaly along the outer shelf and slope. This anomaly is referred to as the East Coast Magnetic Anomaly or Slope Anomaly (Keller and others, 1954; Drake and others, 1963). Taylor, Zeitz, and Dennis (1968) published a magnetic map contoured at an interval of 100 nanoteslas (nT; a $\mathrm{nT}=1$ gamma); the map showed that the inner Continental Shelf is characterized by short-wavelength anomalies suggestive of shallow basement. The outer shelf and Continental Rise are characterized by longer wavelength anomalies suggestive of deeper basement. Taylor, Zeitz, and Dennis (1968) also modeled the East Coast Magnetic Anomaly. These authors inferred a $30-\mathrm{km}$-wide vertical intrusive body that rises to a depth of about $7 \mathrm{~km}$ beneath the sea floor.

A recent high-sensitivity aeromagnetic survey along $185,000 \mathrm{~km}$ (fig. 17) has been interpreted by Klitgord and Behrendt (1979). Estimates of the depths to the sources of the magnetic anomalies were computed along all the profiles of this survey (Hartman and others, 1971; Jain, 1976) by using the Werner deconvolution method (Werner, 1953). In this method, the anomaly is assumed to be due either to a vertical interface (edge model), or to a 100-m-wide dike alined normal to the magnetic profile direction (fig. 18). The depth to the top of source and the susceptibility contrast between opposite sides of the interface, or between the dike and its surrounding material, can then be determined from a set of least-squares solutions of two truncated series that are calculated for several complete passes of a sampling window over the data set. On each pass, a wider sampling window and appropriate low-pass filtering are used to search for deeper sources.

The depths, as calculated from the magnetic data recorded on the shelf, show that the edge solutions were in closest agreement with the seismic data (figs. 19, 20). This solution is compatible with the suggestions that, in this region, the basement is composed of large blocks of continental crust having various susceptibilities (Taylor and others, 1968; Rabinowitz, 1974; Schlee and others, 1976). On the seaward side of the East Coast Magnetic Anomaly, where the acoustic basement is probably oceanic crust (Mayhew, 1974; Sheridan, 1974; Schlee and others, 1976), the depth to the magnetic source was best estimated by the dike solutions. In addition to the depth estimates associated with crystalline and (or) igneous basement, a consistent set of solutions for shallow magnetic sources having weak susceptibilities was computed both landward and seaward of the East Coast Magnetic Anomaly. These sources apparently are in the sedimentary column and may be associated with strong seismic horizons (figs. 19, 20). The weak susceptibility contrasts associated with these anomalies suggest that their sources are neither crystalline nor volcanic rock. Their consistent appearance on adjacent magnetic profiles and their association with strong seismic horizons suggest that the anomalies are real, but further discussion of them at this time would be beyond the scope of this paper.

Similarly, for areas bounded by the East Coast Magnetic Anomaly, we calculated many estimates of depth to magnetic basement being greater than $10 \mathrm{~km}$ together with a set of estimates of magnetic basement being shallow $-6-8 \mathrm{~km}$ below sea floor. The susceptibility contrast associated with the magnetic anomalies interpreted to represent shallow $(6-8 \mathrm{~km})$ magnetic basement suggests that their source is most likely a ridge of magnetic basement rocks (fig. 19, 20). The seismic profiles do not show any identifiable structures below this magnetic basement high, but in most profiles, a disturbed seismic zone has been interpreted as 


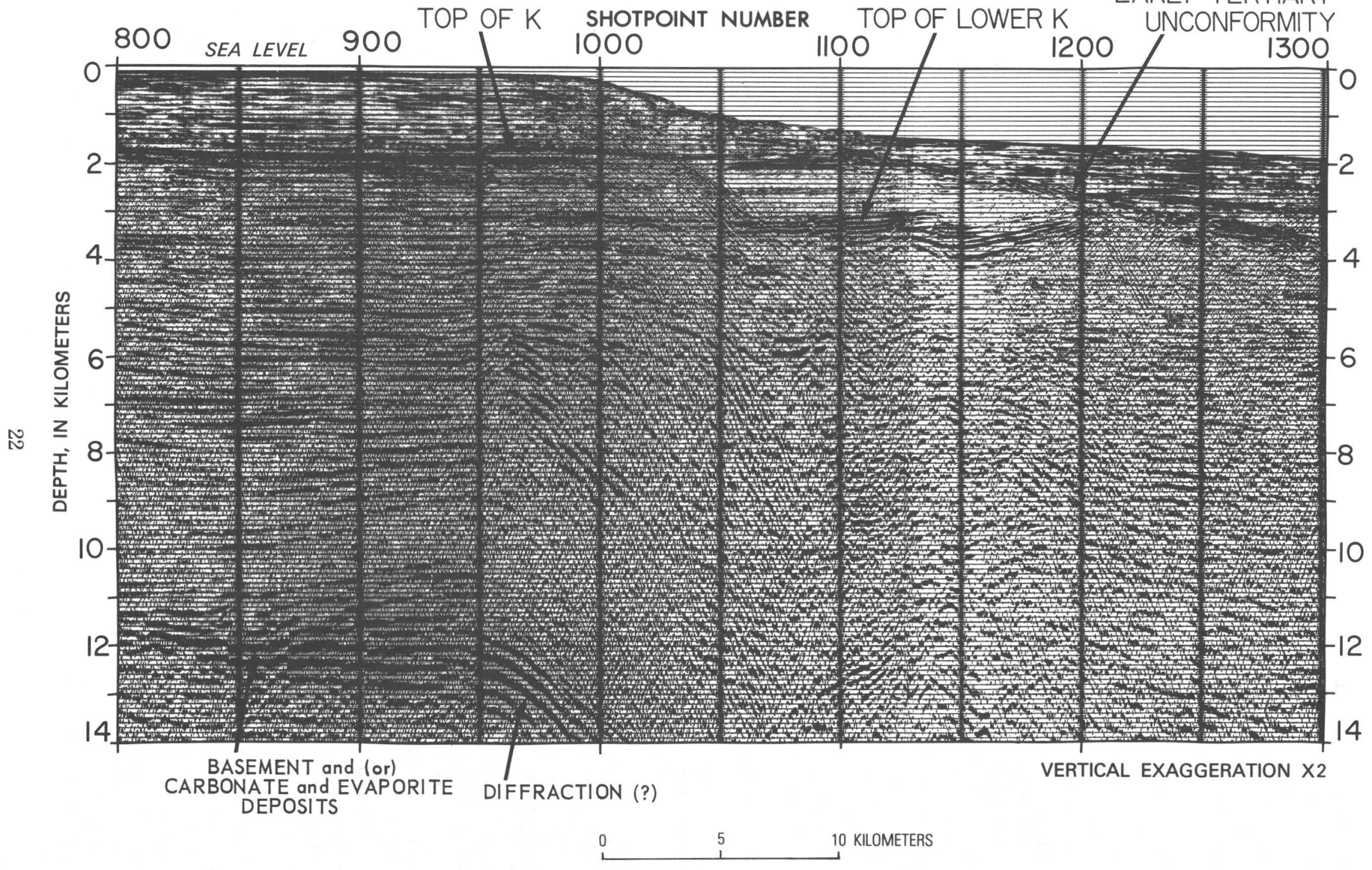

FIGURE 14. - Part of CDP multichannel seismic profile 10 having vertical scale in depth. Location of profile 10 is shown in figures 1 and 9 . Designation used: $\mathrm{K}$, Cretaceous. 


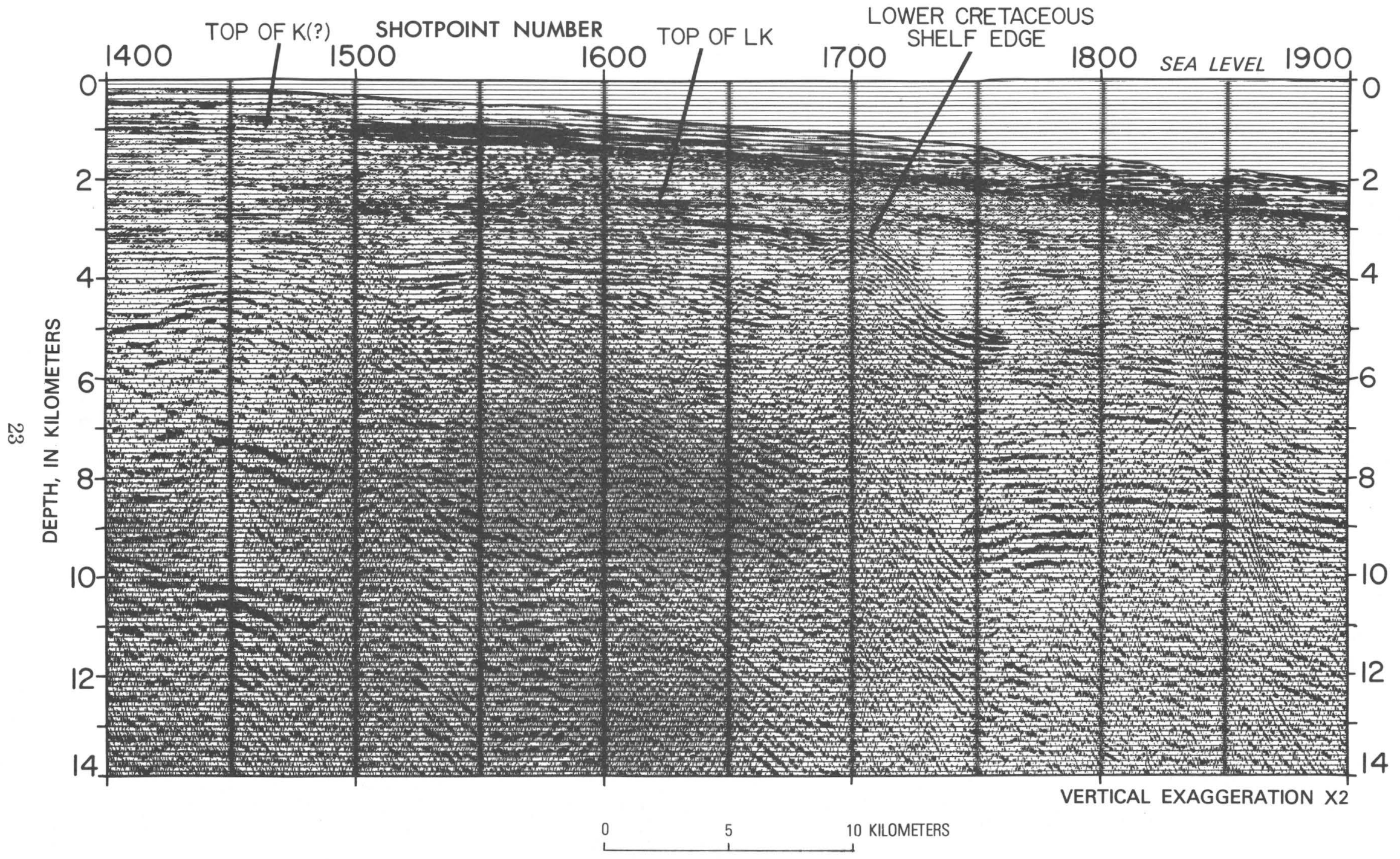

FigURE 15.-Part of CDP multichannel seismic profile 9 having vertical scale in depth. Location of profile 9 is shown in figures 1 and 9 . Designations used: K, Cretaceous; LK, Lower Cretaceous. 


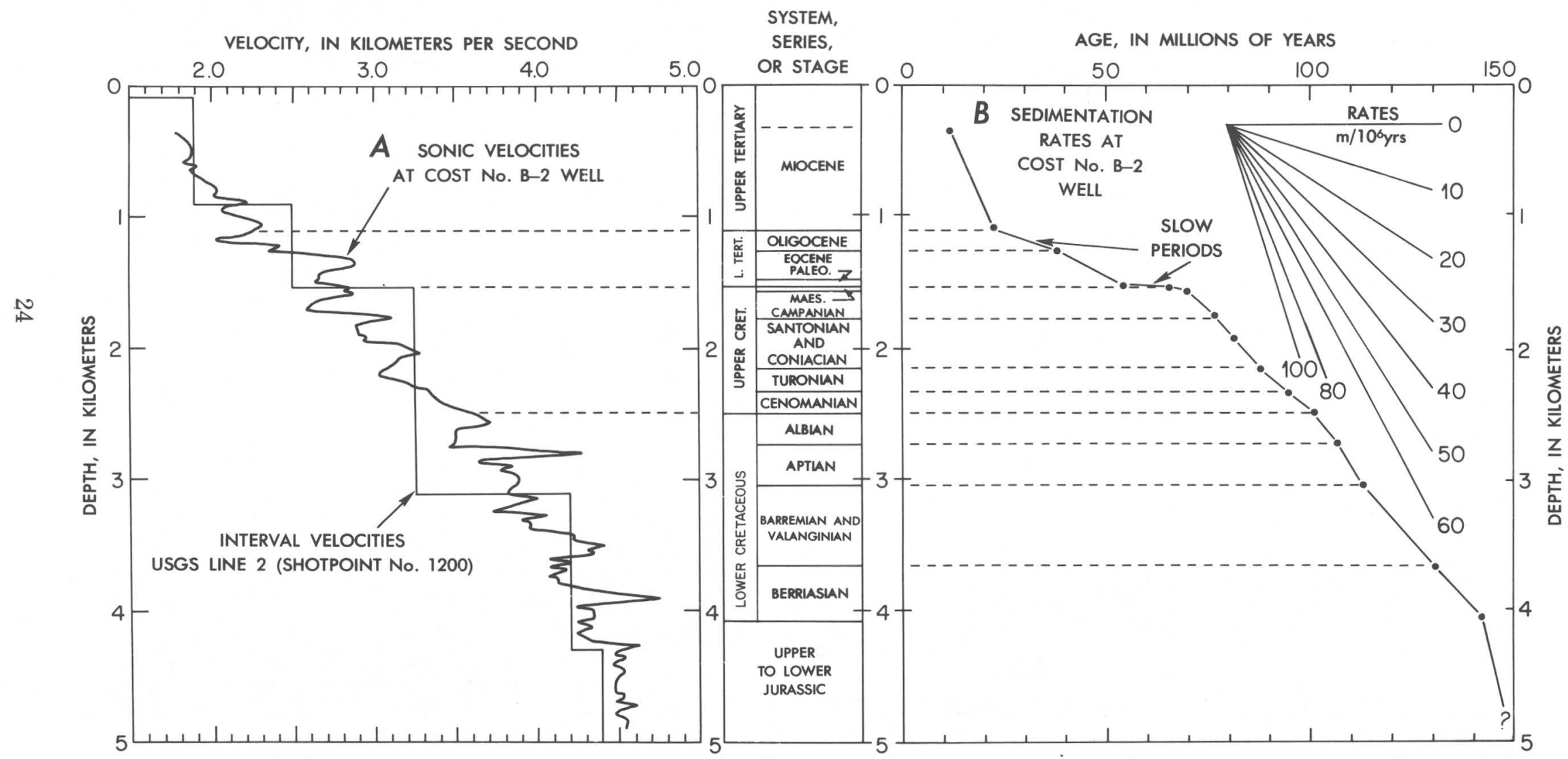

FIGURE 16.- Velocities and deposition rates at the COST No. B-2 well site. A, Velocities recorded on sonic logs from the COST No. B-2 well and velocities calculated from seismic-reflection data. B, Deposition rates in the COST No. B-2 well. The age-versus-depth data are taken from Scholle (1977b), except for the top of the Jurassic, which has recently been revised (E. Robbins, oral commun., 1978). Designations used: Paleo., Paleocene; L. Tert., Lower Tertiary; Maes., Maestrichtian; Cret., Cretaceous. 


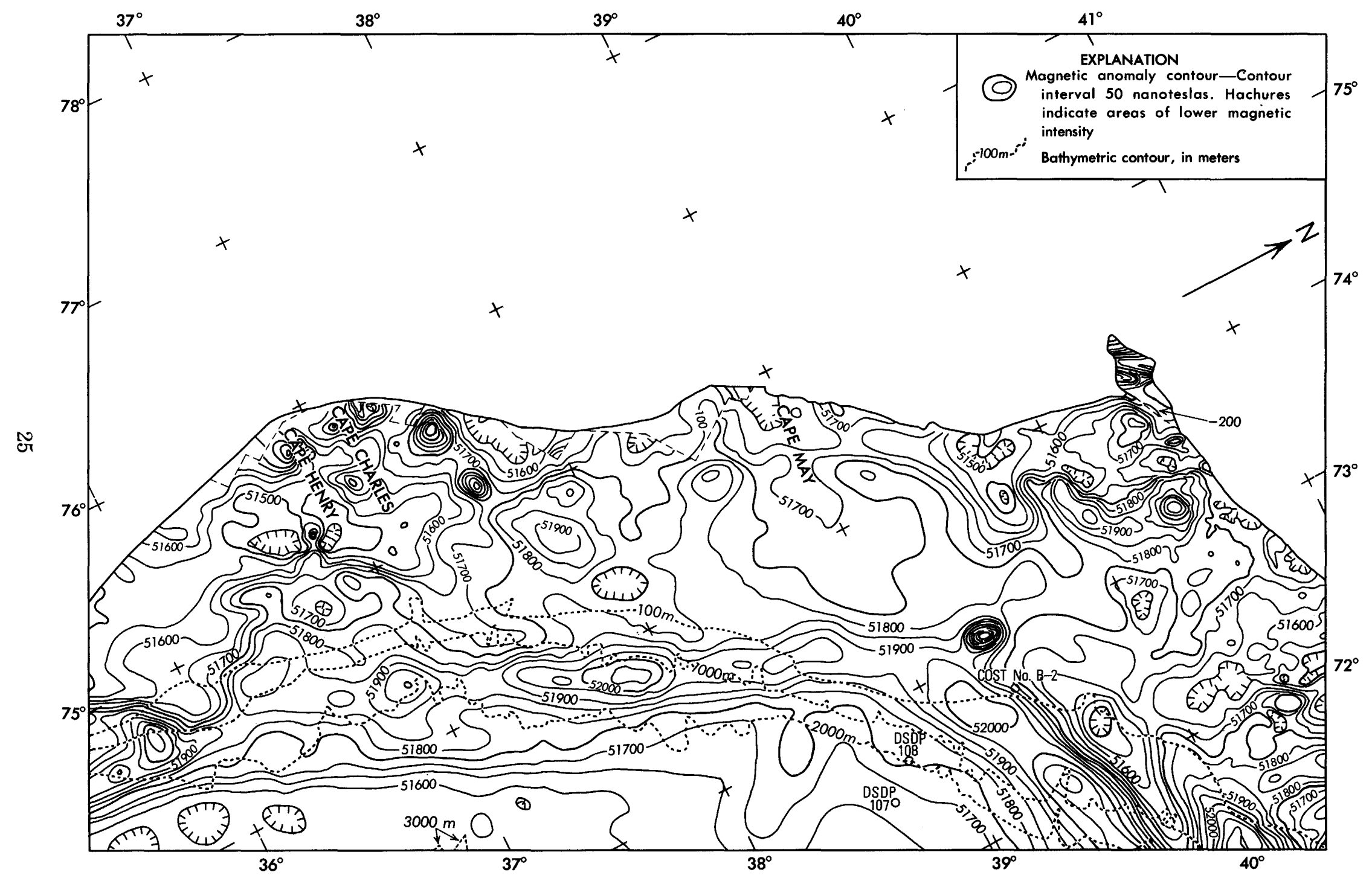

FIGURE 17. - Aeromagnetic anomaly map of the Baltimore Canyon Trough area. Survey was flown in 1975 by LKB Resources, Inc., under contract to the USGS. 
representing carbonate rocks above this high (Schlee and others, 1976).

A contour map of depth to magnetic basement rocks is shown in figure 21 . The controls for this map are the estimates of depth to magnetic basement and the seismic-reflection data. Reference to figure 21 suggests that intrusive bodies underlie the mapped area. The most prominent of these bodies is the Great Stone dome at about lat $39.3^{\circ}$ $\mathrm{N}$., long $73^{\circ} \mathrm{W}$. (Schlee and others, 1976), which is crossed by seismic line 2 (fig. 11). The map suggests that other intrusive bodies could be near Cape Charles and Cape Henry; these would be near the edge of the Baltimore Canyon Trough and may have been intruded into older continental crust.

The estimates of depth to magnetic basement are of particular interest in the vicinity of the shelf break and the East Coast Magnetic Anomaly because the seismic technique has not been able to penetrate more than $6 \mathrm{~km}$ in this region. Depth estimates obtained in this region range from about $7 \mathrm{~km}$ to more than $12 \mathrm{~km}$. The magnetic basement is estimated to be at greater depths both landward and seaward of the East Coast Magnetic Anomaly. Many of the estimated shallower depths to magnetic basement are at about the same location as the conspicuous truncation of seismic reflectors. The calculated susceptibility contrasts are about 10 $\times 10^{-4}$ Gauss per oersted (G/Oe), which is lower than the contrast calculated for the Great Stone dome $\left(25 \times 10^{-4} \mathrm{G} / \mathrm{Oe}\right)$. Basement is calculated to be about $10.5 \mathrm{~km}$ deep on the seaward side of the East Coast Magnetic Anomaly. The greatest depths to basement $(12-13 \mathrm{~km})$ are estimated to be landward of the East Coast Magnetic Anomaly.

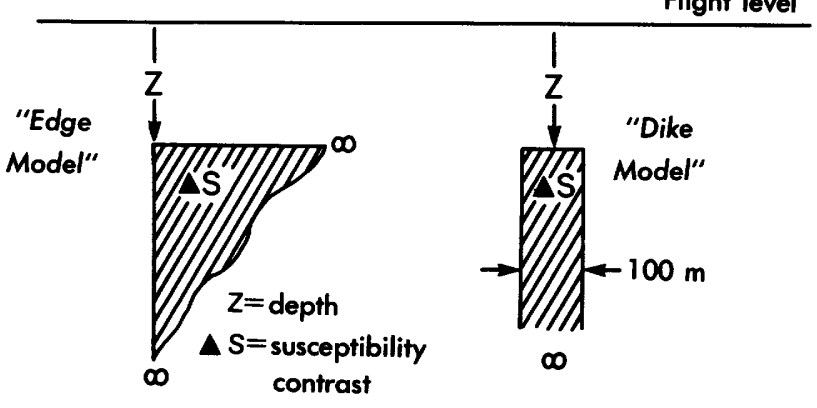

FIGURE 18.-Edge and dike models assumed in making magnetic depth estimates using the Werner (1953) deconvolution method. In the mathematical calculations, the right side of the edge model and the bases of both models were considered to extend to infinity $(\propto)$.

\section{GRAVITY DATA}

Early marine gravity measurements along the U.S. Atlantic margin were made by using pendulum systems aboard submarines (Worzel and Shurbet, 1955; Worzel, 1965). The improvement of surface-ship gravimeters led to a rapid increase in the quality and quantity of data collected in the late 1960 's, and free-air anomaly maps of the continental margin at contour intervals of 20 and $25 \mathrm{mGal}$ (milligals) were published by Emery and others (1970) and Rabinowitz (1974). More recent U.S. Navy and USGS gravity data have been compiled into a free-air anomaly map contoured at an interval of $10 \mathrm{mGal}$ (Grow and others, 1976). The freeair anomalies over the continental margin near Lease Sale No. 49 are shown in figure 22.

The change in topography, crustal type, and crustal thickness across a continental margin, even one in perfect local isostatic balance, results in a positive free-air anomaly along the shelf edge and an adjacent negative anomaly along the base of the slope (fig. 23). The magnitude of this edge effect at the boundary between thick continental crust and thin oceanic crust varies depending on the change in crustal thickness and the abruptness of change, but typical values are $+50 \mathrm{mGal}$ at the shelf edge and $-40 \mathrm{mGal}$ at the base of the slope for an Atlantic-type margin.

Near Lease Sale No. 49, free-air-anomaly values change abruptly along the margin southeast of Delaware Bay and southeast of Atlantic City (fig. 22). The mafic intrusion interpreted on seismic line 2 (fig. 11) as the Great Stone dome was a site for intense bidding during Lease Sale No. 40. It is characterized by a small, circular $+18-\mathrm{mGal}$ anomaly (fig. 22). Another $+10-$ to $+23-\mathrm{mGal}$ elongate high runs north-northeast through western Long Island and is thought to be associated with a high-standing basement block between two Triassic grabens - one along the Hudson River and the other along the Connecticut River. Northeast of the Great Stone dome is a triangular low having values between -20 and - $29 \mathrm{mGal}$. On the shelf southeast of Long Island, anomalies are generally between 0 and $-10 \mathrm{mGal}$, and a few small positive values are as much as +5 mGal.

The free-air minimum along the Continental Slope between Hudson and Wilmington Canyons is extremely low ( $<60 \mathrm{mGal}$ ). This minimum is not related to an anomalously thick sequence of 

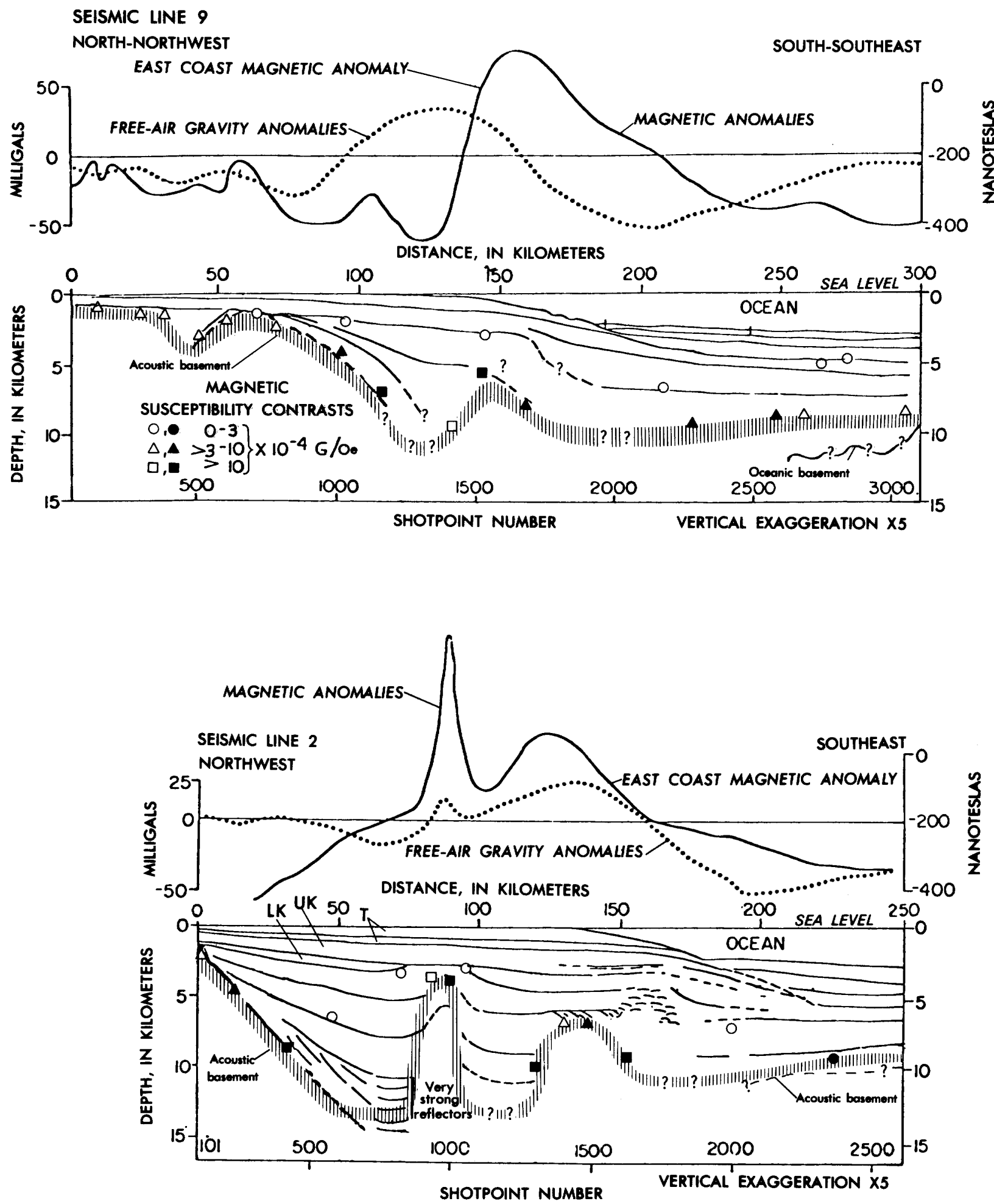

FIGURE 19. - A comparison between seismic-reflection data (lines 9 and 2, figs. 1 and 9 ) and magnetic depth estimates. The magnetic
susceptibility contrast symbols used on top figure T, Tertiary. Solid circles, triangles, and squares represent depth estimates that Lower Cretaceous; UK, Upper Cretaceous; triangles, and squares represent depth estimates that had fewer than 50 solutions. 




VERTICAL EXAGgERATION X5

SHOTPOINT NUMBER

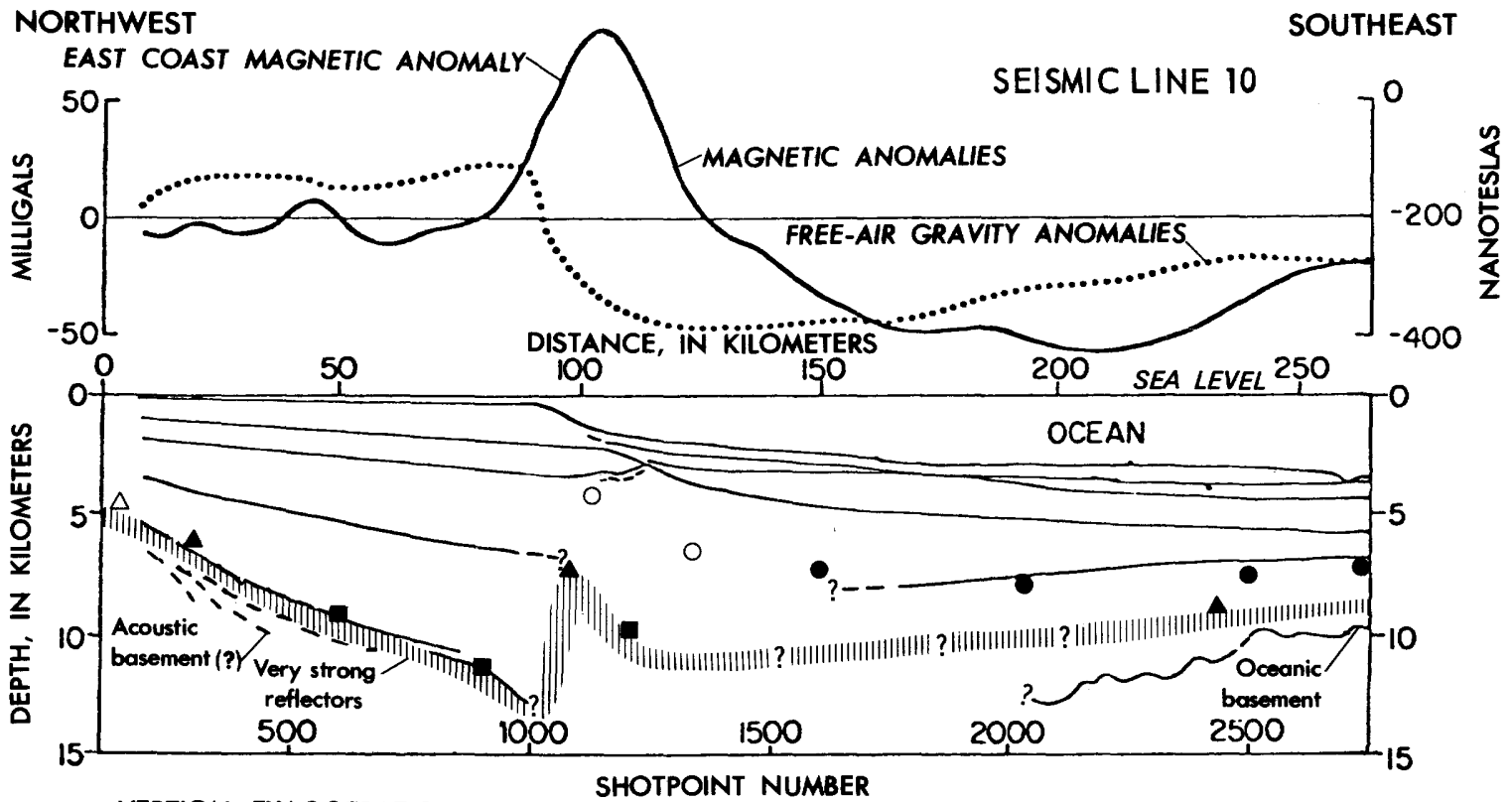

VERTICAL EXAGGERATION X5

Figure 20.-A comparison between seismic-reflection data (lines 6 and 10 in figs. 1 and 9) and magnetic depth estimates. The magnetic susceptibility contrast symbols used on top figure also apply to bottom figure. LK, Lower Cretaceous; UK, Upper Cretaceous; T, Tertiary. Solid circles, triangles, and squares represent depth estimates that had more than 50 solutions. Open circles, triangles, and squares represent depth estimates that had fewer than 50 solutions. 


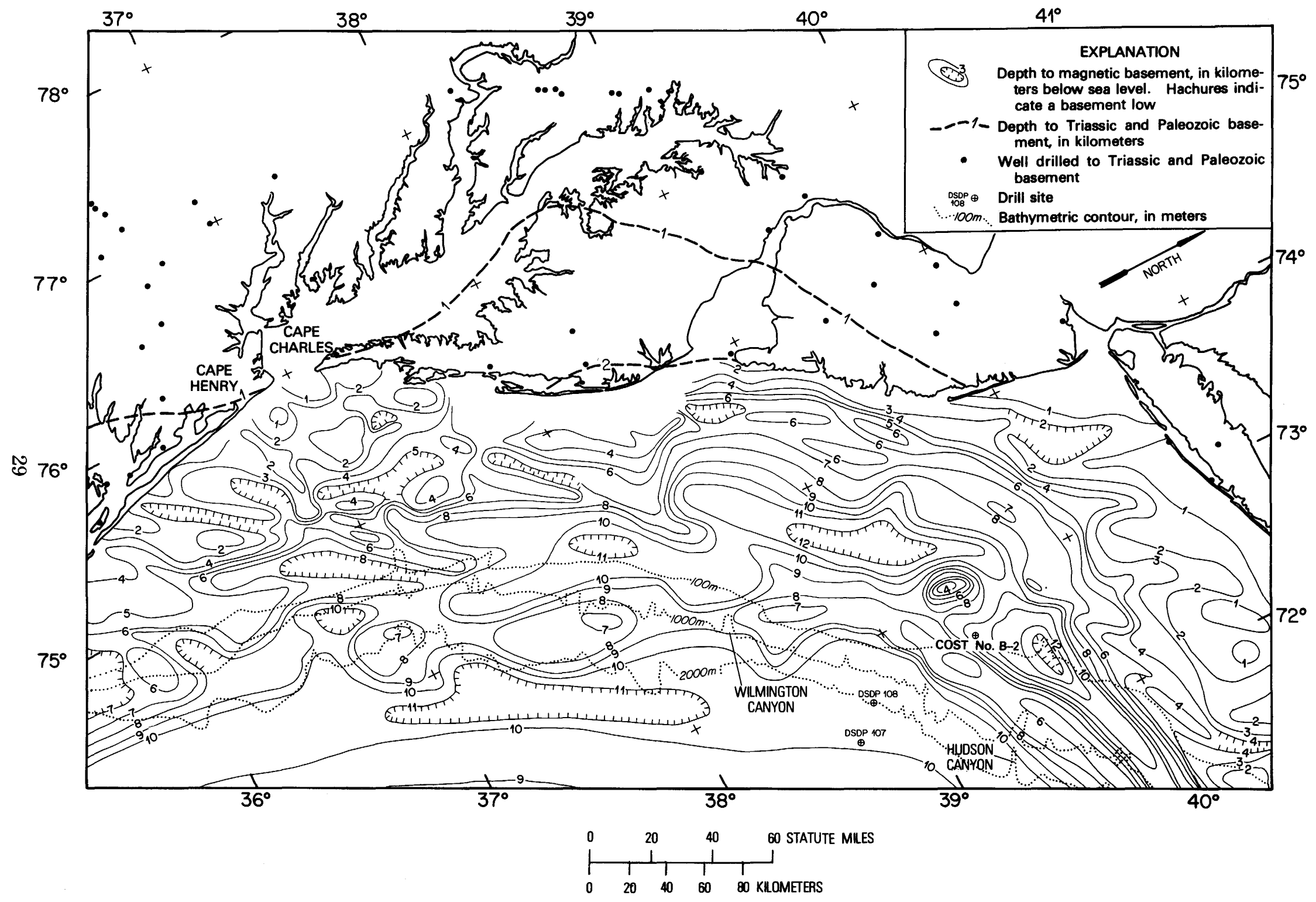

FIGURE 21.-Contour map showing estimated depth to magnetic basement in the Baltimore Canyon Trough area. Contour interval is $1 \mathrm{~km}$. 


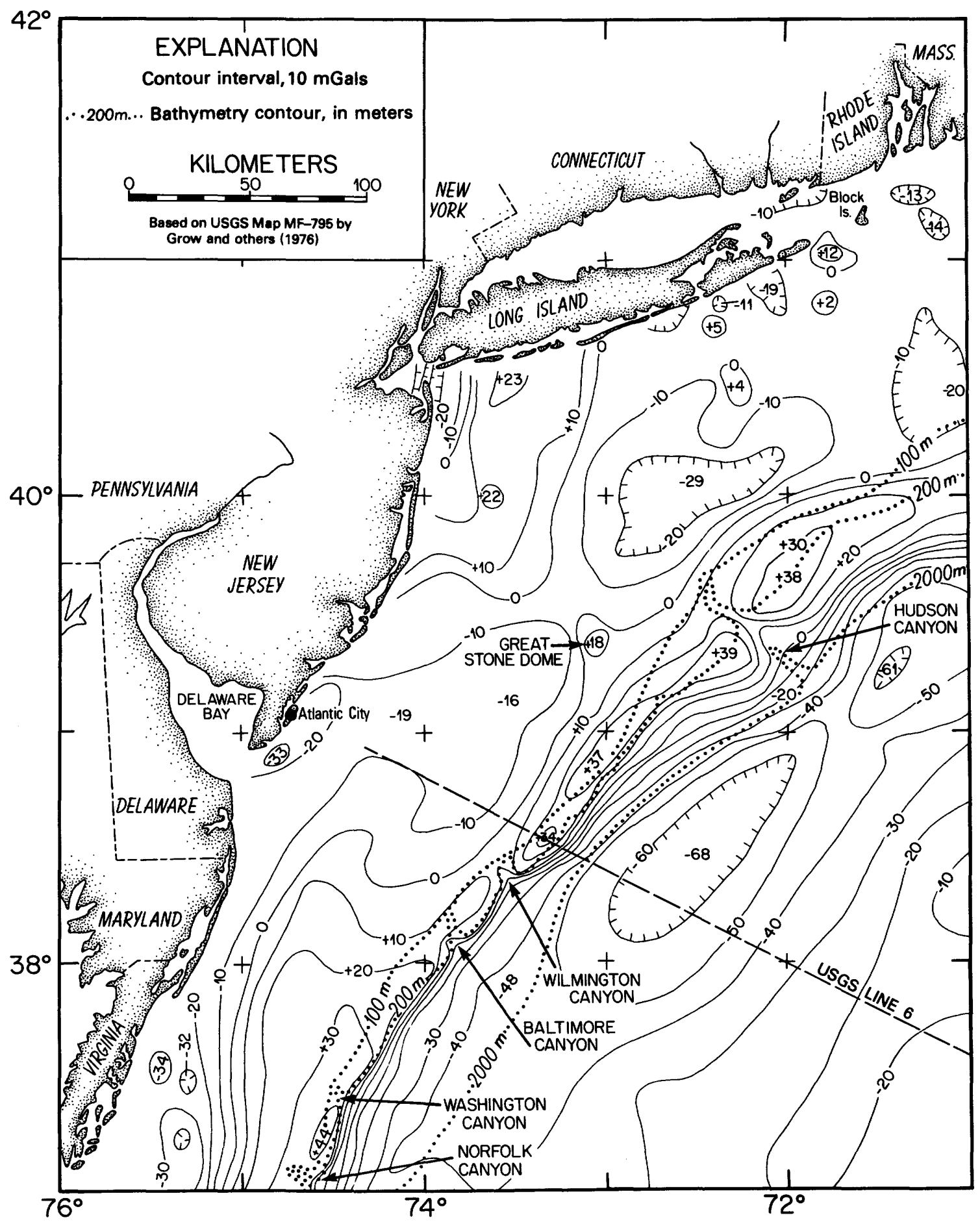

FiguRE 22. - Free-air gravity map of the Baltimore Canyon Trough area. 




FigURE 23. - Gravity anomalies at the continental margin. Figure shows observed free-air gravity anomaly (A), theoretical gravity

(B) calculated from an isostatically balanced model, and isostatic anomaly computed by subtracting A from B. Densities ( $\rho)$ are in grams per cubic centimeter. Location of gravity profile coincides with that of seismic-reflection profile 6 (fig. 22 ).

sediments because seismic-reflection data (lines 2 and 6) and depths to basement calculated from the magnetic data (fig. 21) indicate that the sediment thickness on the rise north of Hudson Canyon and south of Wilmington Canyon is about equal to the sediment thickness between the two canyons. Probably the Mohorovičic discontinuity is 1-2 km deeper between Hudson and Wilmington Canyons than elsewhere in the mapped area.

For interpretation, Rabinowitz (1974) has recommended the use of local Airy isostatic gravity anomalies across continental margins. Such isostatic profiles along seismic lines 2 and 6 are shown in figures 24 and 25 . Although these profiles were computed without correction for the sediment layer, Rabinowitz (1974) has shown that this correction does not significantly change the overall isostatic profile. The values on the isostatic profiles vary considerably along the margin. The anomalies south of line 6 are near zero; along line 6 off Cape May, a regional isostatic anomaly of -30 to -40 $\mathrm{mGal}$ is interrupted by a strong, local high near the upper Continental Slope (fig. 25). To the north, along line 2, broad weak isostatic negative anomalies over the inner shelf and rise are separated by a weak broad high (fig. 24). 


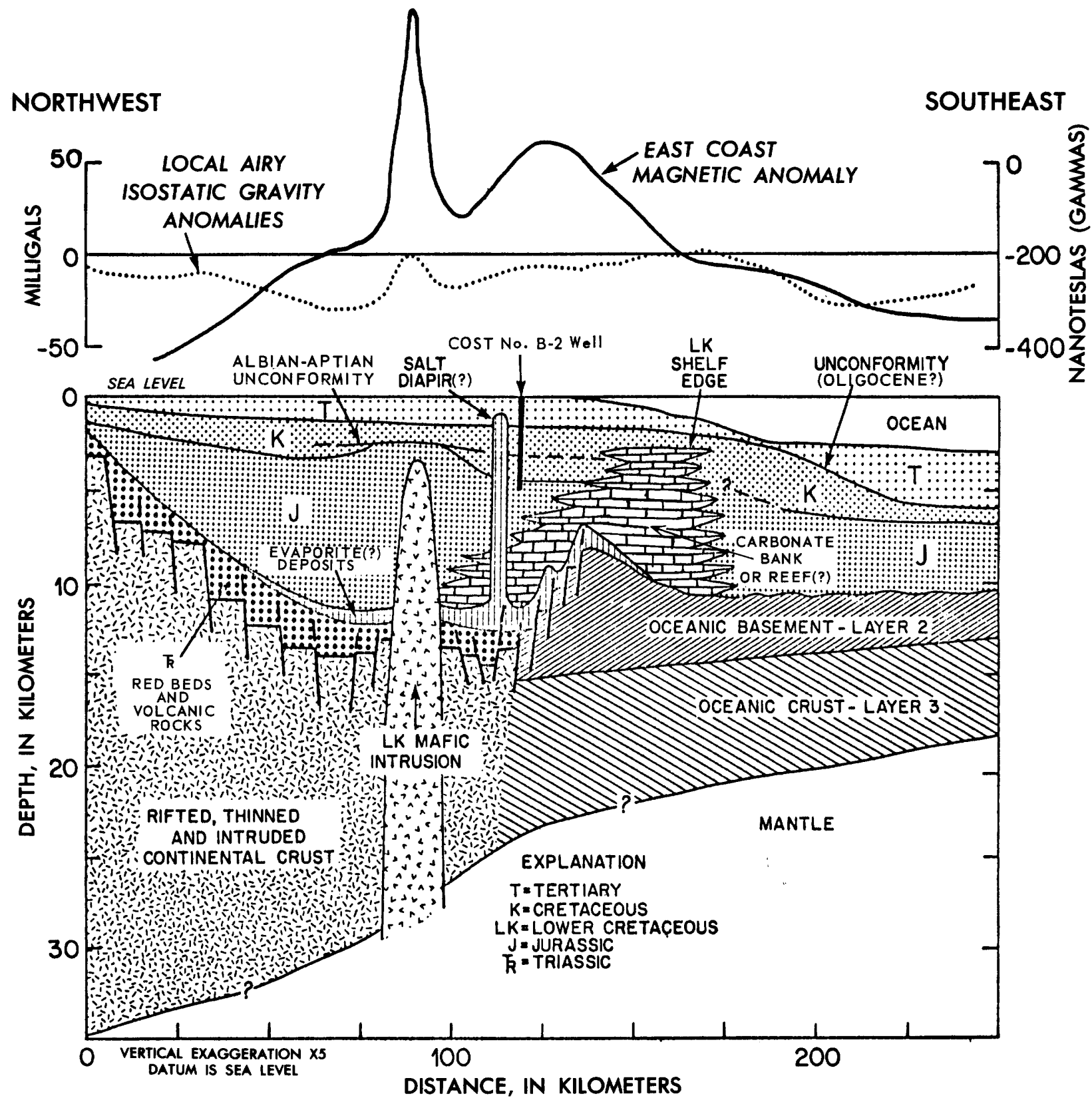

FIGURE 24. - Geologic section across the ocean-continent boundary near seismic profile 2. Diapir projected from $10 \mathrm{~km}$ south of profile, and COST No. B-2 well projected from $10 \mathrm{~km}$ north of profile.

The zone between the shelf and slope-rise areas, which is characterized by shallow seismic penetration $(6 \mathrm{~km})$ and shallow $(8 \mathrm{~km})$ magnetic sources (fig. 21), is marked by a local positive isostatic anomaly (figs. 24, 25) and the nearby East Coast Magnetic Anomaly. Various explanations for this anomalous area have been published. Taylor, Zietz, and Dennis (1968) proposed that the source of the East Coast Magnetic Anomaly was an igneous body $30 \mathrm{~km}$ wide whose upper surface was about 7 $\mathrm{km}$ below sea level. Rabinowitz (1974) proposed that the local isostatic high could be accounted for by high-density material within the basement. Mattick and others (1974) proposed that a basement ridge underlies the outer shelf edge, whereas Schlee and others (1976) proposed that a carbonate bank or reef complex underlies the area. Detailed gravity models of the zone between the shelf and 



FIGURE 25.-Geologic section based on interpretation of seismic profile 6, which crosses the ocean-continent boundary.

slope-rise areas are in preparation. Preliminary results of these studies indicate that a high-density body must underlie the anomalous area between the shelf and rise, an interpretation that is consistent with Rabinowitz's (1974) observations. Highdensity carbonate rocks (3-7 km deep) may account for part of the gravity anomaly, but the magnetic data (fig. 21) seem to indicate that oceanic basement rocks are relatively shallow in this area. Therefore, the gravity anomaly probably is related to a ridge of oceanic basement rocks perhaps capped by high-density carbonate rocks.

\section{THE OCEAN-CONTINENT BOUNDARY AND SUBSIDENCE HISTORY}

The geophysical data are summarized in figures
24 and 25 , which show interpreted geological cross sections along seismic lines 2 and 6 , respectively. The landward edge of the oceanic crust is interpreted as the source of the East Coast Magnetic Anomaly. The oceanic crust is approximately 8 or 9 $\mathrm{km}$ thick near the southeast end of the profiles, and it may thicken to $12-15 \mathrm{~km}$ near the East Coast Magnetic Anomaly. This model is consistent with the model of Rabinowitz and LaBrecque (1977), who proposed that oceanic crust is abnormally thick during the initial stage of continental separation. The continental crust is believed to have been thinned during rifting, but it may also have been intruded by basaltic flows, dikes, and sills.

At least one diapir, believed to be salt, has been mapped on the shelf. In addition, at least seven 
other diapirs have been mapped seismically along the base of the Continental Slope off Cape Hatteras (Grow and others, 1977). Because these diapirs are not associated with measurable magnetic or gravity anomalies, they could be the result of salt flowage (Grow and others, 1977). Although diapirs along this part of the Atlantic margin are few, their presence could indicate that salt deposits exist at depth in the Baltimore Canyon Trough area. In fact, the Houston Oil and Minerals well 676-1 (fig. 1) penetrated salt at a depth of about $3.8 \mathrm{~km}$ (J. C. Hathaway, written commun., 1979). The salt was probably deposited in Late Triassic to Early Jurassic time when restricted oceanic circulation would have created local evaporite conditions (Evans, 1977). The diapir shown in figure 24 and the one off Cape Hatteras (not shown) arch Tertiary sediments and, therefore, may still be active. Their proximity to the landward edge of the oceanic crust suggests that differential subsidence between the shelf and slope-rise areas could have disturbed the deep evaporite horizons and initiated the piercement activity.

Biostratigraphic data from the COST No. B-2 well indicate that the sediments penetrated by the well were deposited in water depths of less than $500 \mathrm{~m}$ and that much of the Cretaceous section was deposited in a shallow-marine or terrestrial environment (Scholle, 1977b). A depth-versus-age curve for the COST No. B-2 well (fig. 16) indicates that the average Tertiary and Cretaceous subsidence rates were 23 and $31 \mathrm{~m}$ per million years, respectively. If the base of the Jurassic section in the Baltimore Canyon Trough is assumed to be at a depth of $12 \mathrm{~km}$, then the Jurassic subsidence rate would be approximately $120 \mathrm{~m}$ per million years, or nearly four times the Cretaceous rate.

According to Watts and Ryan (1976), if the effect of sediment loading is removed, rifted margins subside in an exponentially decreasing manner similar to that found for midocean ridges. The subsidence of these margins is controlled primarily by cooling and thermal contraction of the lithosphere (Sclater and others, 1971; Sleep, 1971). Watts and Ryan (1976) noted that additional driving mechanisms, such as gravitational outflow of crustal material (Bott, 1971) and deep crustal metamorphism (Falvey, 1974), may be required to explain the large amounts of subsidence seen along Atlantic-type continental margins. The Baltimore Canyon Trough has nearly four times as much sediment fill as have the basins studied by Watts and
Ryan (1976) and is one of the deepest basins along the Atlantic margin.

Although the subsidence history of the sediments of the slope-rise area has not been detailed by any deep drill holes, the landward-dipping sedimentary horizons below the slope and upper rise on USGS line 2 (at a depth of $8-10 \mathrm{~km}$, fig. 12) suggest that subsidence there has been less than that beneath the shelf. (The dip reversal is accounted for by growth faults, as shown on figure 66 by Mattick, Scholle, and Girard (this volume).) If the continental crust beneath the shelf was not rigidly coupled to the oceanic crust during the Jurassic Period, then the shelf and slope-rise areas could have subsided independently (fig. 26). The boundary between areas having different rates of subsidence may have been a narrow zone at the landward edge of the oceanic crust through Jurassic and Early Cretaceous time. However, the continuity of Upper Cretaceous and lower Tertiary horizons (on seismic records) across the outer shelf and upper slope indicates that major tectonic activity and differential rates of subsidence terminated near the end of Early Cretaceous time.



Figure 26. - Subsidence rates of shelf and adjacent slope-rise areas in the Baltimore Canyon Trough area. 
According to Grow and Markl (1977), during the Late Cretaceous about $1 \mathrm{~km}$ of sediment was deposited on the shelf and somewhat less was deposited on the rise (at least where sediment thickness has been mapped off Cape Hatteras rise). Because Tertiary sediments on the shelf are less than $1.5 \mathrm{~km}$ thick and those on the rise are more than $2.5 \mathrm{~km}$ thick, we conclude that during the Tertiary, sediments tended to bypass the shelf. Therefore, during the Tertiary, the subsidence rate of the slope-rise area probably was greater than that of the shelf area.

\section{STRATIGRAPHY}

Poag (this volume) and Schlee (this volume) both discuss the stratigraphy and paleoecology of the Baltimore Canyon Trough area; however, each author uses a somewhat different approach. The interpretations of Poag are based on preliminary analyses of foraminiferal assemblages derived from 17 offshore borings and on a review of published stratigraphic investigations of Coastal Plain wells. His data on deposits onshore are largely taken from the comprehensive compilation by Brown, Miller, and Swain (1972). Schlee describes the seismic units delineated on the seismic records and attempts to interpret the lithology of these units and the environments in which they were deposited. Poag's analyses are limited to the deepest sediments penetrated in drill holes, whereas Schlee interprets the stratigraphy and paleoecology of sequences below the bottom of the COST No. B-2 well.

\section{FORAMINIFERAL STRATIGRAPHY AND PALEOECOLOGY}

By C. Wylie PoAg

In this section, biostratigraphic and paleoenvironmental interpretations are based chiefly on the distribution of planktic and benthic foraminifers, but calcareous nannoplankton, radiolarians, and diatoms also yielded significant information. Figure 27 shows the location of sample sites and of the cross sections constructed from these studies.

For those units from which samples are not available (chiefly rock units deeper than the bottom of the COST No. B-2 well), interpretations are derived from seismic-reflection studies (Schlee, this volume) and from stratigraphic evidence obtained from the Scotian Shelf, U.S. Atlantic Coastal Plain, and Bahamas Platform. Figure 28 shows the major geologic and seismic units in the Baltimore Canyon Trough area (see also Schlee, this volume).

\section{PRE-CRETACEOUS ROCKS}

A schematic paleoecologic cross section of the Baltimore Canyon Trough is shown in figure 29. Interpretation of the pre-Cretaceous units is based chiefly on the work of Schlee (this volume) and Grow and Klitgord (this volume); however, Jurassic rocks have been penetrated in several wells in the studied area (Brown and others, 1972; Perry and others, 1975). Coarse micaceous feldspathic nonmarine sandstones, red and green shales, and a few marine limestones constitute most of the thickest Jurassic interval in the Salisbury and Albemarle embayments $(215 \mathrm{~m}$ in the Esso-Hatteras Light No. 1 well; Brown and others, 1972; Perry and others, 1975). A few meters of fossiliferous limestone overlying the sandstone in this well may also be of Jurassic age because it contains the foraminifer $A n$ chispirocyclina lustitanica (Egger). The COST No. B-2 well penetrated Jurassic rocks having a similar lithology but also containing thin marine shale beds. Dinoflagellates in a core at $4,060 \mathrm{~m}$ from the COST No. B-2 well indicate a Kimmeridgian (Jurassic) age (E. I. Robbins, oral commun., 1977). The precise age at the bottom is not known but is assumed to be Jurassic (figs. 28, 29).

\section{CRETACEOUS}

The COST No. B-2 well penetrated approximately $2 \mathrm{~km}$ of chiefly nonmarine Lower Cretaceous sandstone and shale containing lignite and coal beds. The sandstones are fine, medium, and coarse grained; the shales are red, green, and gray (Scholle,1977b). Drill-hole data from the onshore Coastal Plain (Brown and others, 1972; Perry and others, 1975) indicate that the lithology and paleoenvironment of Lower Cretaceous sedimentary rocks there are similar to those of the Lower Cretaceous sedimentary rocks penetrated in the COST No. B-2 well (figs. 28 and 29). In onshore outcrops, Lower Cretaceous rocks are generally assigned to the Potomac Group. Schlee (this volume) and Mattick, Scholle, and Girard (this 


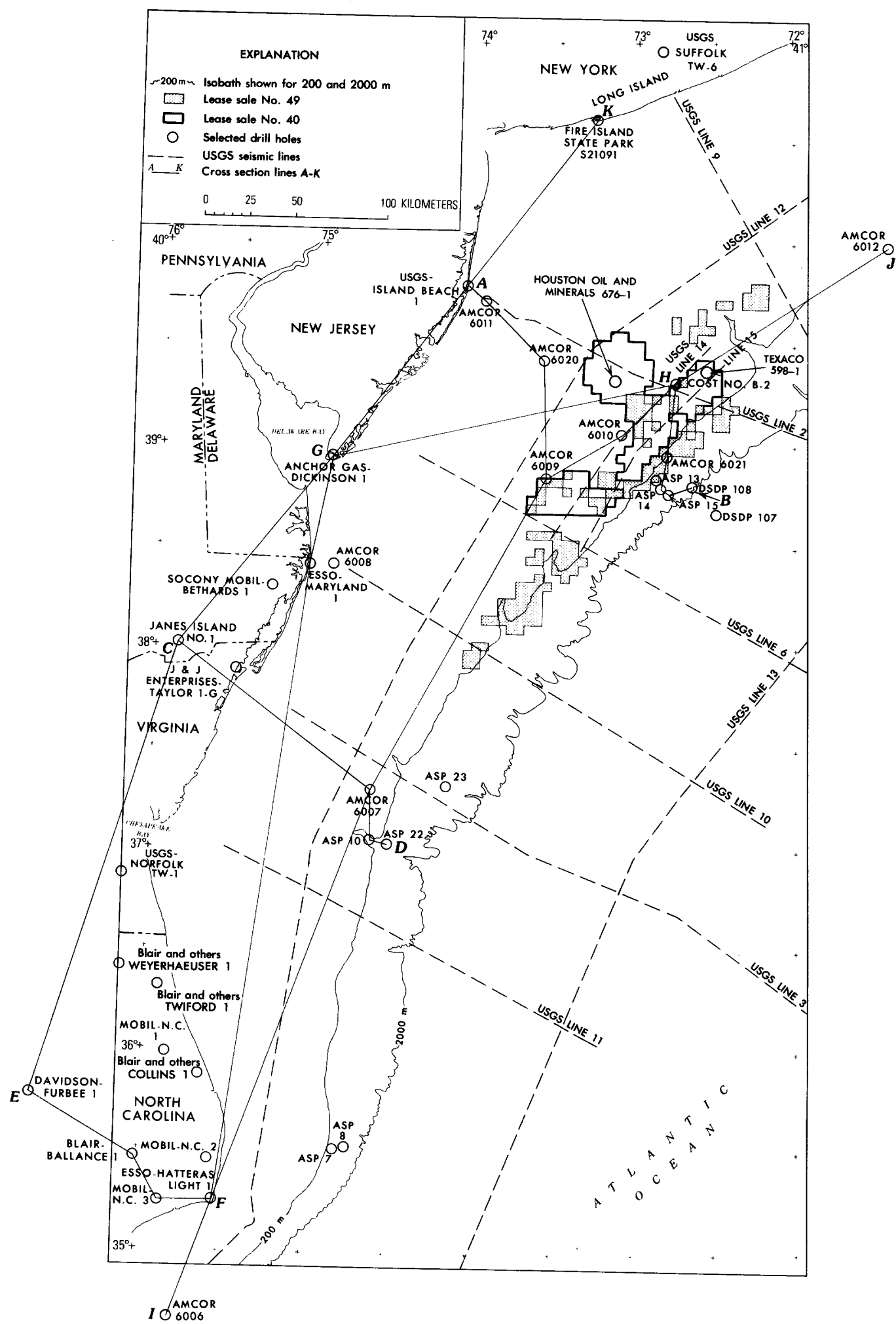

FigURE 27. - Map of the United States mid-Atlantic margin showing locations of lease tracts, seismic grid, and sample sites (coreholes and drill holes). Lettered cross sections are illustrated in figures 28-35. In 1967, a consortium of oil companies conducted the Atlantic Slope Project (ASP), during which coreholes were drilled at eight sites. In 1976, the USGS undertook the Atlantic Margin Coring Project (AMCOR), and cores were recovered at 19 sites (9 in the Baltimore Canyon Trough area). Sediment penetration at ASP and AMCOR sites was limited to $330 \mathrm{~m}$. 


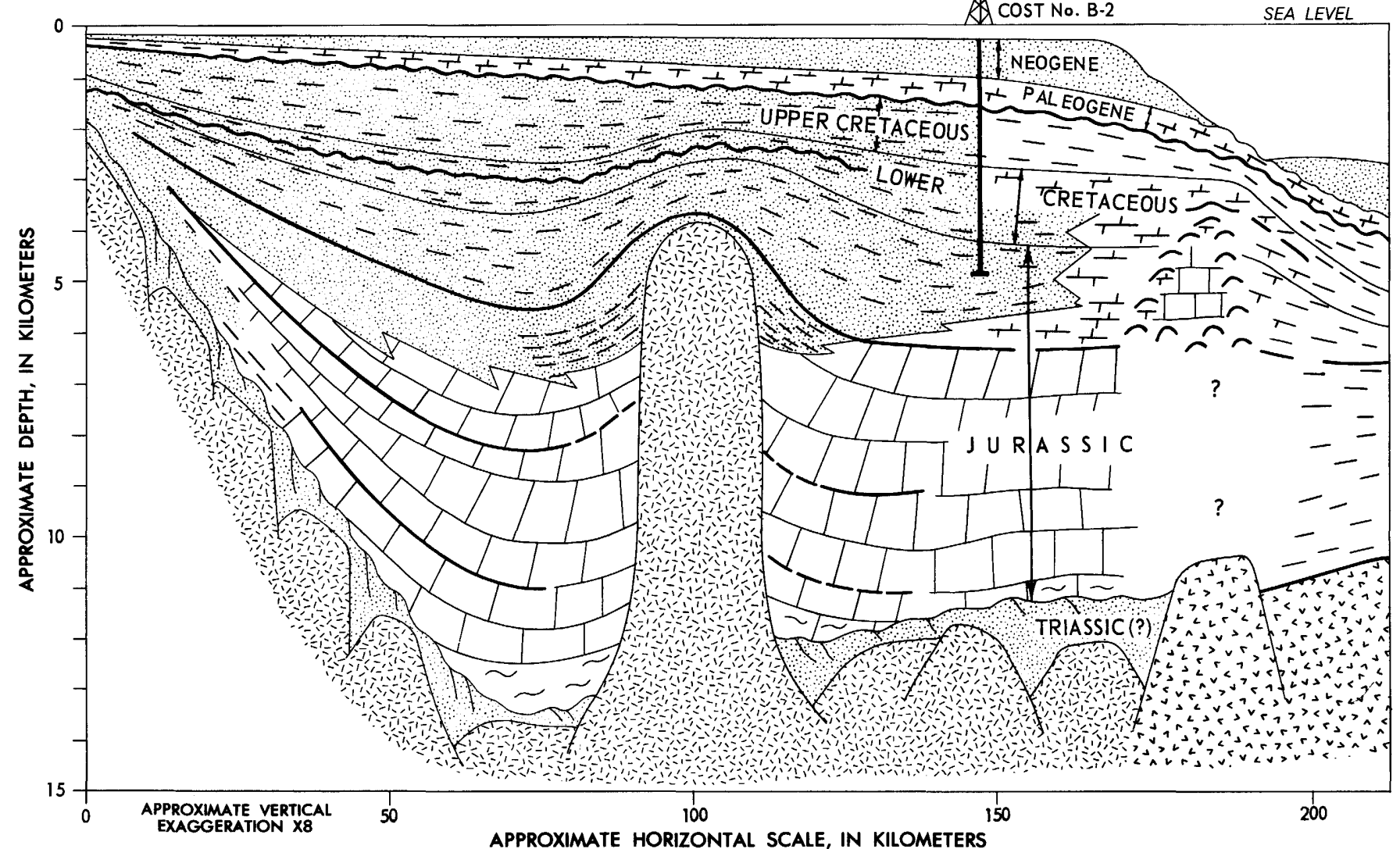

\section{EXPLA N A T I O N}

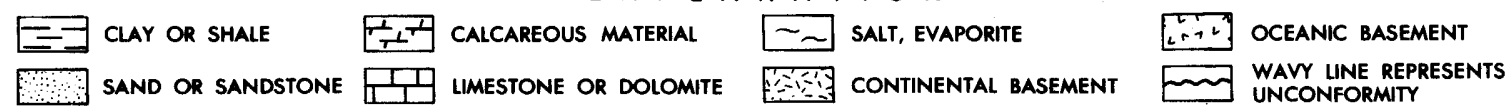
مَ REEF

FIGURE 28. - Schematic geologic cross section of the Baltimore Canyon Trough ( $A-B$ on fig. 27). Strong seismic reflectors, in some areas coinciding with uneonformities, are indicated by heavy black lines. General geometry of major rock units is approximately to scale, but thicknesses within the Cenozoic strata are not to scale. (This distortion is necessary to show the stratigraphic relationships.) Adapted from Poag (1978). 


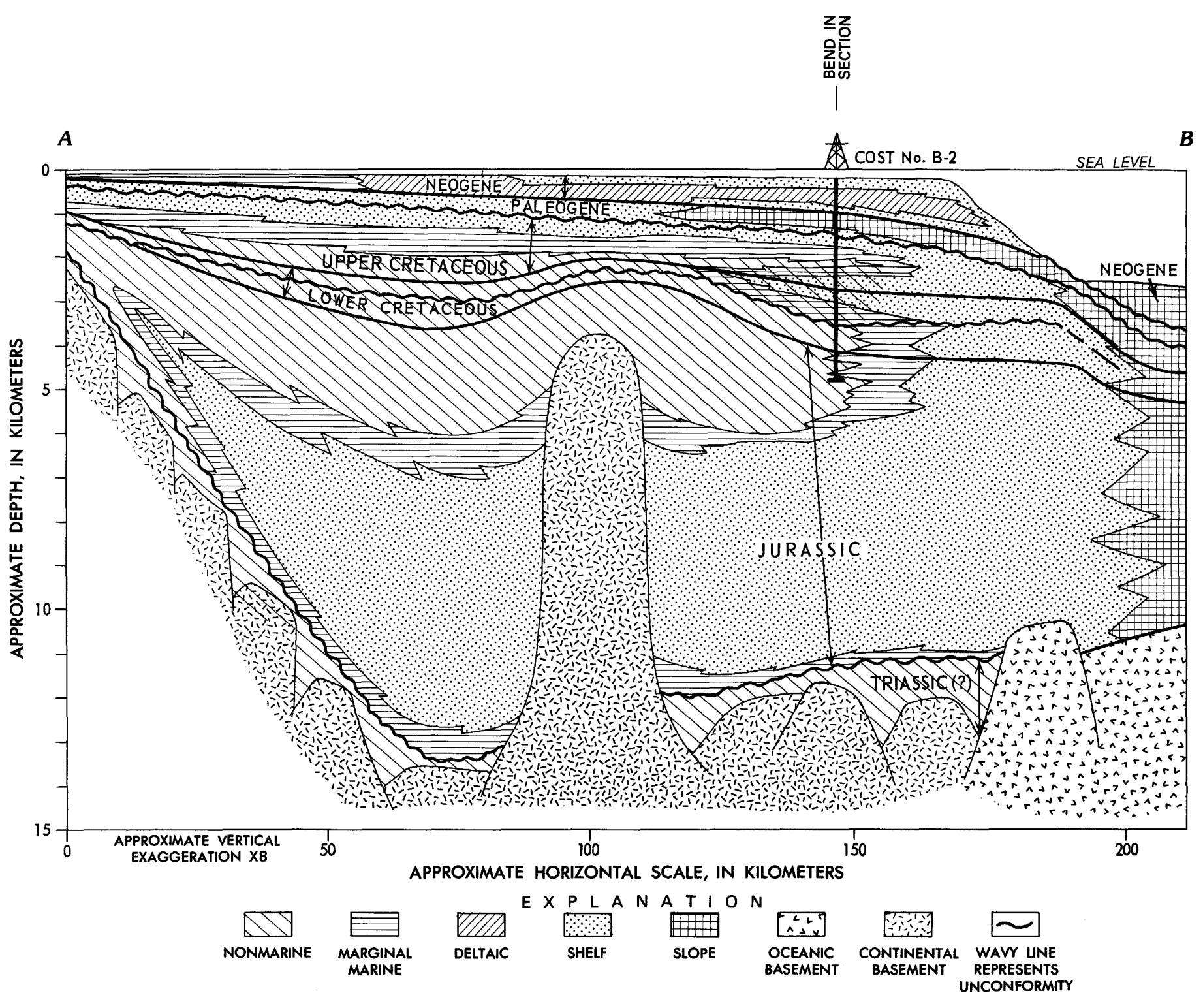

FIGURE 29. - Schematic paleoecologic cross section of the Baltimore Canyon Trough ( $A-B$ on fig. 27). Strong seismic reflectors, in some areas coinciding with unconformities, are indicated in heavy black lines. Interpretations of paleoecology of rocks deeper than about $5 \mathrm{~km}$ and those seaward of COST No. B-2 well are based on seismic characteristics (Schlee, this volume), extrapolation from drill holes on the U.S. Atlantic Coastal Plain (Brown and others, 1972), and analogy with the Scotian Shelf (Jansa and Wade, 1975a). 
volume) suggest that seaward of the COST No. B-2 well, Lower Cretaceous rocks are limestone and dolomite and, locally beneath the slope, form a fringing reef complex that bordered much of the Baltimore Canyon Trough during the Late Jurassic and Early Cretaceous (fig. 28). Determination of palynological zones within the Cretaceous Coastal Plain sedimentary rocks indicates that the Upper Cretaceous may extend deeper than was formerly thought. Perry and others (1975) presented a reassessment of Mesozoic Coastal Plain stratigraphy; detailed studies of palynomorphs include those by Sirkin (1974), Wolfe (1976), Doyle and Robbins (1977), and Christopher (1977).

Upper Cretaceous strata in the COST No. B-2 well show an increasing prevalence of marine deposition and consist of nearly $1,000 \mathrm{~m}$ of dominantly shallow marine sandstone, limestone, and shale (figs. 28, 29). Microfossils are abundant in much of the Upper Cretaceous section and reflect a marine shelf paleoenvironment. This change from nonmarine to marine conditions during Late Cretaceous time also is recorded in coastal wells from Cape Hatteras to New Jersey and is further manifest in sandy and clayey outcrops of the Raritan and Magothy Formations and the Matawan and Monmouth Groups (Perry and others, 1975).

Seaward from the COST No. B-2 well, Upper Cretaceous mudstone and foraminiferal ooze have been dredged from the slope off New Jersey. They appear to have been deposited in bathyal conditions (Gibson and others, 1968).

Meisburger (1977) has recovered abundant assemblages of well-preserved Late Cretaceous planktic foraminifers, which are present in sand as much as $30 \mathrm{~m}$ thick beneath the shallow coastal waters of North Carolina, between Cape Fear and Cape Lookout. Turbidite deposits on the Continental Rise off Cape Hatteras also contain Late Cretaceous microfossils (reworked) derived from outcrops on the nearby Continental Slope (Emery and Uchupi, 1972; Weed and others, 1974).

\section{PALEOCENE}

Paleocene rocks from beneath the shelf have been sampled only in the COST No. B-2 well. An interval of approximately $10 \mathrm{~m}$ of relatively dense buff limestone contains microfossil assemblages deposited on the middle to outer shelf (fig. 30). Paleocene strata thicken to $60 \mathrm{~m}$ westward under the New Jersey Coastal Plain. The shallow-marine nature of the microfossils is maintained, although the lithology changes to gray and white calcareous clay and sand. Southwestward beneath Cape Hatteras, $30 \mathrm{~m}$ of gray to white, calcareous, shallowmarine sandy clay and clayey sand represents the Paleocene. In outcrop, equivalent beds are placed in the Beaufort, Brightseat, Aquia, Marlboro (lower part), Hornerstown, and Vincentown Formations.

\section{EOCENE}

Eocene strata have been penetrated in many offshore boreholes (including COST No. B-2 well, AMCOR 6011, ASP 15 and 22, and DSDP 108) and also have been sampled in several dredges and cores from Hudson Canyon and on the shelf and slope off North Carolina (fig. 27).

On the New Jersey shelf, approximately $20 \mathrm{~m}$ of blackish to gray-green silty clay and fine silty glauconitic sand of middle to early(?) Eocene age was penetrated in AMCOR 6011 (fig. 30). The benthic species of calcareous foraminifers from this interval indicate that it was deposited under middleshelf conditions. Directly westward in the New Jersey Coastal Plain (Salisbury embayment), a more complete section of shallow marine Eocene rocks can be sampled. These rocks are gray to green clay, sandy clay, sand, and greensand and are approximately $150 \mathrm{~m}$ thick. Outcropping Eocene strata are included in the Castle Hayne, Nanjemoy, and Manasquan Formations and Shark River Marl (Brown and others, 1972).

Southward from New Jersey, the Eocene section of the Coastal Plain thickens. At Cape Hatteras, the Eocene section is chiefly limestone and glauconitic sand and is about $300 \mathrm{~m}$ thick even though upper Eocene rocks are missing (fig. 31). Eocene beds thin shoreward of Cape Hatteras (fig. 31). Eocene strata also are present near the sea floor on the North Carolina shelf between Cape Fear and Cape Lookout. The beds there contain a bryozoan hash and shallow-water benthic foraminifers (Meisburger, 1977).

At the site of the COST No. B-2 well, the Eocene section appears to be nearly complete and is $270 \mathrm{~m}$ thick (fig. 30). In this well, the uppermost $90 \mathrm{~m}$ of Eocene rocks consists of impermeable, buff, calcareous shale; the middle $90 \mathrm{~m}$ is white chalky limestone; and the lowermost $90 \mathrm{~m}$ is buff shale and cream limestone. All these rocks are rich in 




FIGURE 30.-Schematic dip section showing stratigraphy and paleoecology of sedimentary rocks in the northern Baltimore Canyon Trough area (approximately line $A-B$ on fig. 27). 




FIGURE 31. - Schematic dip section showing stratigraphy and paleoecology of sedimentary rocks in the southern Baltimore Canyon Trough area (Albemarle embayment beneath North Carolina Coastal Plain; $E-F$ of fig. 27). 


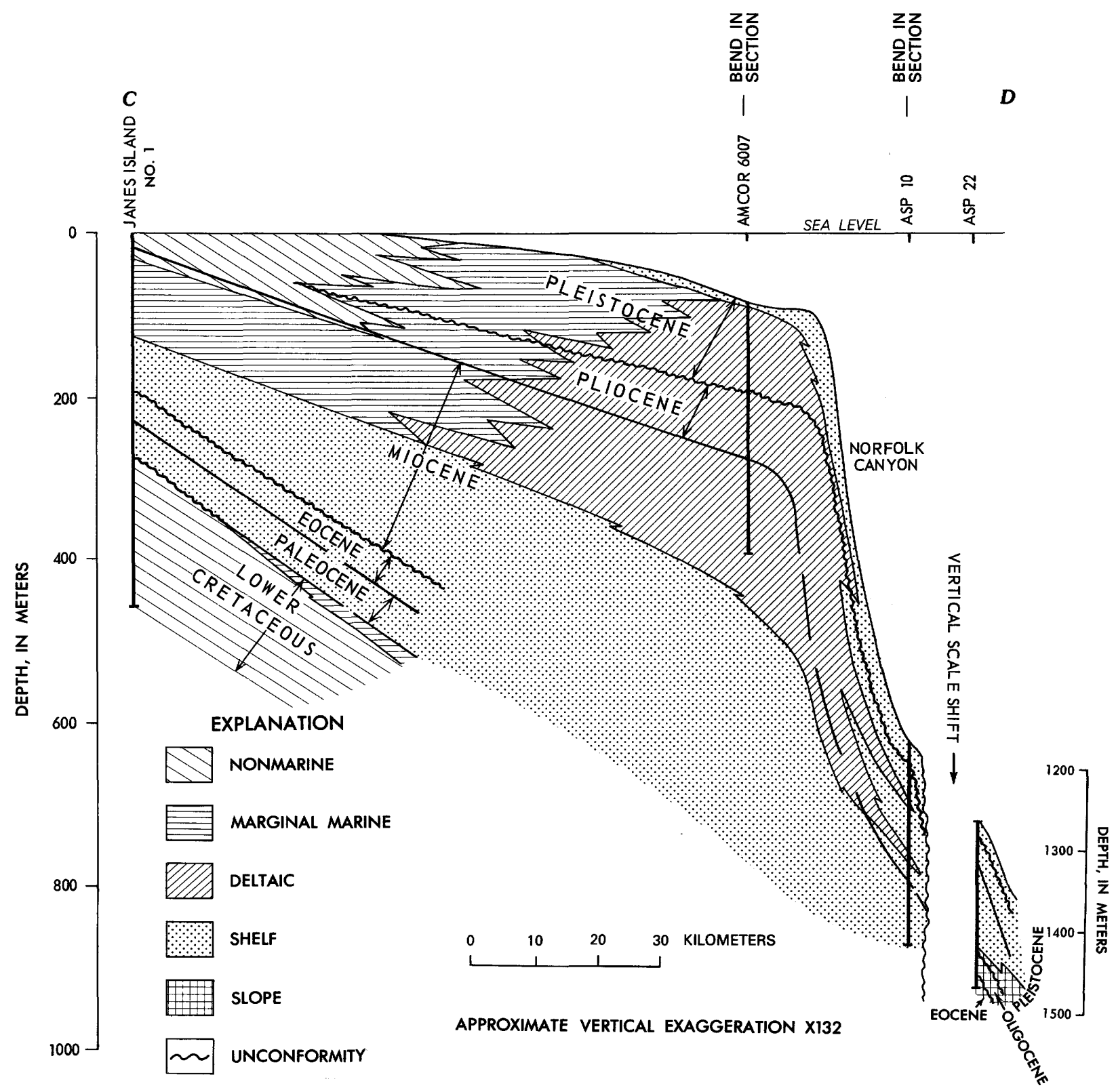

FIGURE 32. - Schematic dip section showing stratigraphy and paleoecology of sedimentary strata in the central Baltimore Canyon Trough area ( $C-D$ of fig. 27).

planktic microfossils and nannofossils that accumulated in bathyal conditions. They represent the maximum marine transgression known in the Baltimore Canyon Trough area.

On the Continental Slope, three holes have penetrated Eocene strata (ASP 15 and 22 and DSDP 108; figs. 30, 32). ASP 15 penetrated approximately $100 \mathrm{~m}$ of middle Eocene, pale yellowgray, siliceous calcilutite; DSDP 108 penetrated 37 $\mathrm{m}$ of light-gray siliceous calcilutite of the same age.
Approximately $200 \mathrm{~km}$ southward, ASP 22 penetrated $15 \mathrm{~m}$ of buff to yellow-gray siliceous calcilutite of late Eocene age. All these slope samples contain rich radiolarian assemblages in addition to abundant planktic foraminifers and calcareous nannoplankton and were deposited in bathyal depths.

In Hudson Canyon, yellowish calcilutite deposits and white chalks of early, middle, and late Eocene age have been dredged (Gibson and others, 1968); 
they, too, contain bathyal calcareous microfaunas including abundant radiolarians.

On the North Carolina slope, several dredge hauls have recovered dense, tan and greenish, sandy limestone and foraminiferal calcilutite of Eocene age (Weed and others, 1974), but the presence of siliceous microfossils there has not been established.

\section{OLIGOCENE}

In the offshore area, the most complete section of Oligocene rocks occurs in the COST No. B-2 well; the only other Oligocene samples in this area are from the shelf and the slope off North Carolina. The COST No. B-2 well penetrated approximately $150 \mathrm{~m}$ of upper and lower Oligocene strata composed largely of buff to light-gray calcareous shale and claystone and of impermeable limestone near the top of the section (fig. 30). These strata accumulated in a shelf environment.

According to Brown, Miller, and Swain (1972), Oligocene strata have not been reported from the onshore Coastal Plain of Virginia, Maryland, Delaware, and New Jersey (fig. 33). However, recent field work has revealed that upper Oligocene sediments crop out along the Pamunkey and Chickahominy Rivers in Virginia (J. E. Hazel, USGS, written commun., 1978). In the subsurface at Cape Hatteras (Albemarle embayment), an interval of $66 \mathrm{~m}$ of white sandy limestone, sand, and clay and green glauconitic, clayey sand represents Oligocene shallow shelf deposition (figs. 31, 34). Similar strata (former "Trent Marl") crop out in North Carolina, where they are overlain by shelly sands of the "Silverdale beds." Between Cape Fear and Cape Lookout, N. C., shallow cores and seismic-reflection profiles reveal a homogeneous fine sand as much as $80 \mathrm{~m}$ thick. Samples of this sand contain shallow-water benthic foraminifers, ostracodes, and mollusks of Oligocene age (Meisburger, 1977; L. W. Ward and J. E. Hazel, written commun., 1978).

The Oligocene sediments recovered from the Hatteras slope include calcareous glauconitic siltstone, sandstone, and $\tan$ chalk that were dredged from a water depth of $1,525 \mathrm{~m}$ (Weed and others, 1974).

\section{MIOCENE}

Miocene rocks of the United States mid-Atlantic margin have been studied in considerably more detail than have been the older rocks. They were penetrated by AMCOR 6007, 6009, 6010, 6011, 6012?, and 6016 (beyond areas shown in fig. 27); ASP 10, 14, and 15; and COST No. B-2 well (fig. 27).

Near the New Jersey shore (AMCOR 6011), approximately $172 \mathrm{~m}$ of largely shelly, gray to grayish-brown, fine, medium, and coarse sand containing beds of gray clay and grayish-brown silty clay was drilled (fig. 30). Microfossils in this section are chiefly diatoms, but radiolarians also are common. Calcareous nannoplankton and foraminifers are sparse. These sediments were deposited in shallow marginal marine conditions.

Beneath the New Jersey Coastal Plain, Miocene rocks are similar to those from AMCOR 6011, but the sand is less shelly and less marine (fig. 30). According the Maher and Applin (1971) and Brown, Miller, and Swain (1972), Miocene deposits beneath Cape Hatteras are much thicker (as much as $400 \mathrm{~m}$; figs. 31,35 ) than those beneath the New Jersey Coastal Plain. In the Miocene deposits beneath Cape Hatteras, gray to white sand predominates, but greensand and sandy limestone also are present. Sandy Miocene strata, some containing diatomaceous beds, thin updip (fig. 33) and crop out as the Pungo River, Calvert, Choptank, St. Marys, and Kirkwood Formations.

In the COST No. B-2 well, Miocene rocks thicken dramatically (fig. 30). More than $800 \mathrm{~m}$ of unconsolidated to semiconsolidated gray sand, gravel, and clay was penetrated. Diatoms are abundant in the microfossil assemblages, especially in middle and lower Miocene strata. Foraminifers are largely benthic species indicative of deltaic or near-deltaic conditions. The thick sequences of foreset bedding seen on geophysical profiles support the interpretation that the biota are deltaic (Schlee, this volume).

Along the Outer Continental Shelf from Virginia to Long Island (AMCOR 6007, 6009, and 6010; fig. 35), upper(?) Miocene sediments were penetrated to a maximum thickness of about $130 \mathrm{~m}$ (AMCOR 6009 ). The lithology, microfossils, and derivation of these sediments are similar to those of Miocene sediments penetrated in the COST No. B-2 well. Sparse calcareous nannoplankton suggest that the bottom $10 \mathrm{~m}$ of AMCOR 6012 may also be of Miocene age, but the lack of foraminifers or diatoms 


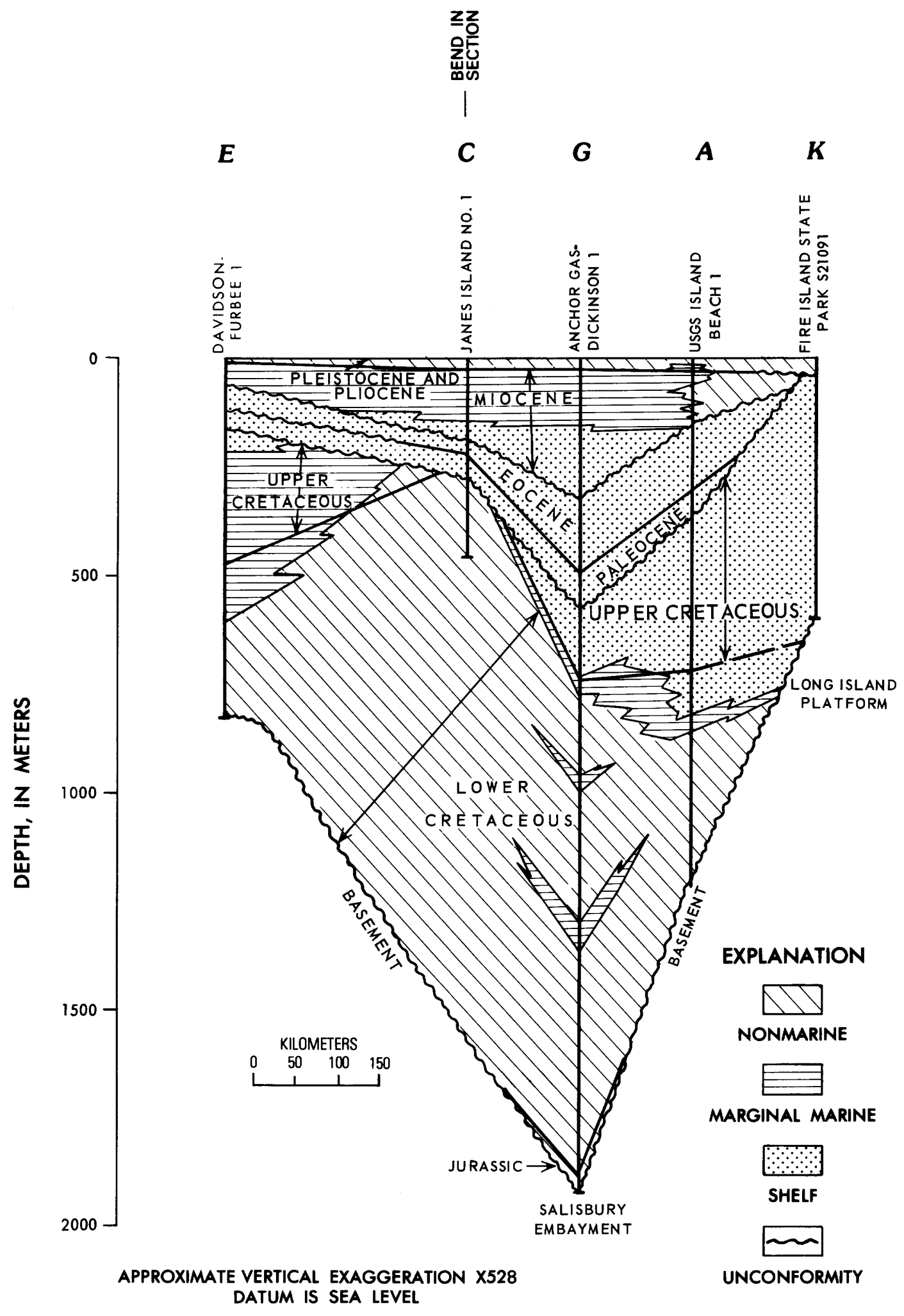

FIGURE 33. - Schematic strike section showing stratigraphy and paleoecology of the Coastal Plain segment of the Baltimore Canyon Trough area ( $E, C, G, A, K$ in fig. 27). Basement configuration is somewhat distorted owing to choice of wells; for example, the Norfolk arch is not shown. 


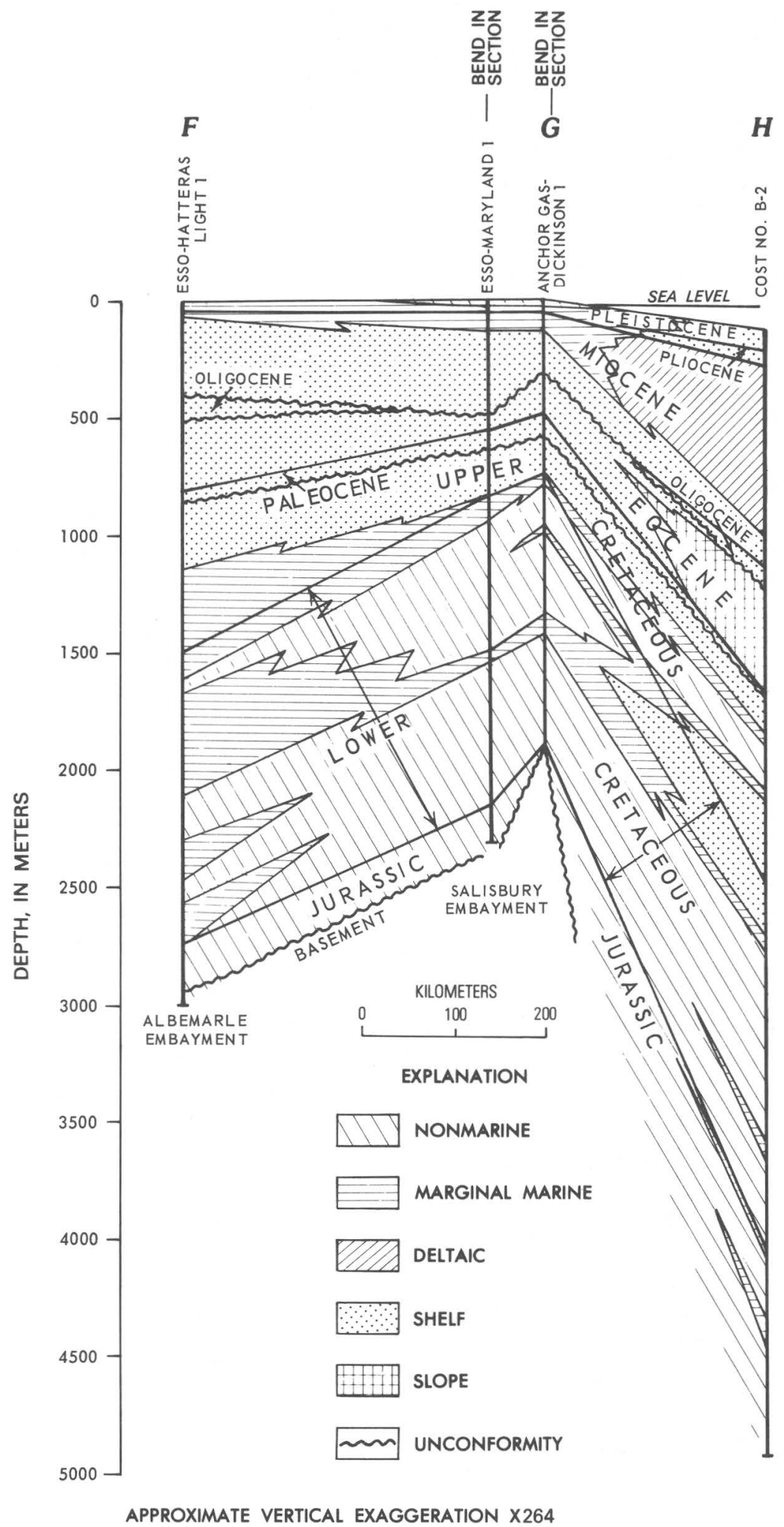

FiguRE 34.-Schematic stratigraphic and paleoecologic section (approximately along strike) through four wells that penetrated Jurassic rocks within the Baltimore Canyon Trough area ( $F, G, H$ in fig. 27). Basement configuration is distorted owing to choice of wells. 




APPROXIMATE VERTICAL EXAGGERATION X 660

FIGURE 35. - Strike section showing schematic stratigraphy and paleoecology of upper Cenozoic rocks at the seaward margin of the Baltimore Canyon Trough ( $I-J$ in fig. 27). 
precludes a confident interpretation of the paleoenvironment.

On the New Jersey slope (ASP 14, 15; fig. 30), diatomaceous sediments of probable Miocene age (possibly as thick as $83 \mathrm{~m}$ in ASP 14) are composed of dark olive-gray to yellowish-brown glauconitic sand and silty clay. Outer shelf conditions of deposition are inferred for these strata.

In the Norfolk Canyon area off Virginia (ASP 10; fig. 32), middle Miocene diatomaceous beds were cored. The section is composed of olive-gray to yellowish-brown clay, sandy clay, and clayey sand lacking conspicuous glauconite except in the lowest few meters. The diatoms are benthic and planktic marine species mixed with freshwater species; this mixture suggests that fluvial-marine deposition occurred nearby.

Four piston cores in and near Hudson Canyon reportedly recovered Miocene sediments (Ericson and others, 1961), but reevaluation of the published microfossil and nannofossil content of these samples suggest that they are probably of Pliocene age.

\section{PLIOCENE}

Pliocene sediments in the Baltimore Canyon Trough were penetrated in AMCOR 6007, 6009, and 6010, in ASP 7 and 10, and in scattered piston cores (fig. 27). In the Coastal Plain, they may be included in the post-Miocene strata, which are chiefly coarse to fine, gray to white, shelly sand and silty clay, a few tens of meters thick (Pleistocene and Pliocene beds shown in fig. 33). In outcrop, Pliocene sediments constitute the Yorktown and Duplin Formations, the Cohansey Sand, and the lower part of the Croatan Formation (Hazel, 1977).

Near the New Jersey shore, cores taken from AMCOR 6011 indicate that about $65 \mathrm{~m}$ of gray to white sand and silty clay is present; the clay is barren of fossils, but some of it may be Pliocene (fig. $30)$. In the COST No. B-2 well, a 66-m-thick interval of unconsolidated, white to gray sand and clayey sand contains a sparse inner-shelf benthic foraminiferal fauna that suggests it is of Pliocene age (figs. 30,35 ). Near the seaward edge of the New Jersey shelf, AMCOR 6010 penetrated about $65 \mathrm{~m}$ of gray silty clay and gray to olive sand that contains sparse Pliocene benthic foraminifers (figs. $30,35)$. The fauna, in conjunction with abundant lignite particles and other organic matter, suggest lagoonal deposition.
To the south, AMCOR 6009 penetrated $25 \mathrm{~m}$ of gray silty clay and gravel containing pyritized diatoms and a shallow shelf assemblage of Pliocene foraminifers (fig. 35). At the seaward edge of the shelf, east of the mouth of Chesapeake Bay, AMCOR 6007 penetrated about $65 \mathrm{~m}$ of richly diatomaceous, olive-gray, silty clay and gray clayey sand of Pliocene age (figs. 32, 35). The few foraminifers in this unit are shallow-marine benthic species that preferred the high-nutrient conditions commonly found around deltas.

Downslope, adjacent to Norfolk Canyon, ASP 10 penetrated approximately $166 \mathrm{~m}$ of diatomaceous Pliocene olive-gray silty clay (fig. 32). The diatoms suggest middle-shelf to outer-shelf environment, but the influence of a nearby river is reflected in the significant number of freshwater forms.

On the Hatteras slope (ASP 7), about $15 \mathrm{~m}$ of olive-gray, highly calcareous, clayey sand and sandy clay contains abundant late Pliocene planktic foraminifers and calcareous nannoplankton (fig. 27). Green foraminiferal calcilutite of the same age, containing bathyal faunas, has been recovered from Hudson Canyon and vicinity (Ericson and others, 1961).

\section{PLEISTOCENE}

Pleistocene sediments have been recovered in almost every core taken in the Baltimore Canyon Trough area. Onshore, Pleistocene sediments may be included in undifferentiated post-Miocene deposits (Pleistocene and Pliocene beds shown in fig. 33). These deposits are generally white to gray, shelly to nonfossiliferous, fine to coarse sand containing some silty clay and may be as much as $30 \mathrm{~m}$ thick (figs. 30, 31, 33, 34). These beds were probably deposited in nonmarine and marginal marine conditions. Outcropping Pleistocene beds have been included in several formations-for example, the Waccamaw, the upper part of the Croatan, Flanner Beach, Pamlico, "Kempsville," and Norfolk Formations and Gardiners Clay (Brown and others, 1972; Hazel, 1977).

Nearshore the AMCOR 6011 (fig. 30) and 6008 coreholes penetrated as much as $120 \mathrm{~m}$ of unconsolidated gravel and gray, shelly to barren sand and silty clay of Pleistocene age. These strata constitute marginal marine, lagoonal, and probably fluvial channel-fill deposits. Farther offshore beneath the shelf, Pleistocene sediments thicken and change facies. At AMCOR 6007, 6009, and 
6010 , Pleistocene beds are dark gray to olive-gray, clayey and silty sand (in many places shelly) and silty clay (figs. 30 and 35). Maximum thickness is about $170 \mathrm{~m}$ at AMCOR 6010. Alternating lagoonal, inner shelf, and middle to outer shelf strata form complex vertical facies; glacialinterglacial cycles have not yet been clearly defined.

The COST No. B-2 well penetrated nearly $250 \mathrm{~m}$ of white to gray, unconsolidated, shelly to barren gravel, sand, and clay of Pleistocene age (figs. 30, 35 ). The vertical facies changes were somewhat masked by the drilling methods, but shallow marine to nonmarine strata appear to dominate.

On the Continental Slope, surprisingly thick Pleistocene sequences of gray to dark-gray, gassy, silty and sandy clays were penetrated in AMCOR 6012 and 6021 (figs. 30, 35) and in ASP 7, 22, and 23. Thicknesses range from about $162 \mathrm{~m}$ in ASP 22 to more than $300 \mathrm{~m}$ in AMCOR 6021 and ASP 23, where pre-Pleistocene strata were not reached. Planktic foraminifers of temperate-water origin are scattered throughout the Pleistocene strata, and some intervals are rich in diatoms, middle to outer shelf benthic foraminifers, and dark organic particles. This association suggests deposition in anoxic depressions on the shelf. Except a thin interval of indigenous slope deposits in the bottom of AMCOR 6021, all Pleistocene foraminiferal assemblages appear to have been displaced onto the slope from original deposition sites on the shelf. Ericson and others (1961) recognized an abundance of Pleistocene turbidite deposits from evidence in more than 30 piston cores from the Hudson Canyon area (Continental Slope and Rise). For example, the deltalike submarine fan near the canyon mouth contains coarse-grained layers (including gravels) that show grading of well-sorted particles, abundant plant detritus, and remains of shallow-water mollusks and benthic foraminifers. High-resolution seismic profiles indicate that Pleistocene turbidite deposits and submarine slumps are common all along the incised Continental Slope of this region (McGregor and Bennett, 1977).

\section{HOLOCENE}

Emery and Uchupi (1972) have concluded that about 73 percent of the surface sediment on the Atlantic Outer Continental Shelf is relict-that is, a remnant body of sediment originally deposited in the early Holocene. This conclusion has been further substantiated by Sheridan and others (1974), Stahl and others (1974), and Knebel and Spiker (1977). Cores, dredges, and high-resolution profiles show that the sediment cover is a distinctive sheet of medium to coarse, poorly sorted sand that in many places is yellow brown because of ironstained quartz and feldspar grains; the sediment contains peat, remains of land vertebrates, and oyster shells. It reaches thicknesses of $20 \mathrm{~m}$ along the seaward edge of the New Jersey shelf, but it is not differentiated on the cross sections illustrated herein. Holocene sediments on the Continental Slope are mainly green silty clay and clayey silt whose carbonate content (mainly planktic foraminifers) increases as distance from shore increases and which is subject to frequent mass movement downslope.

\section{ACOUSTIC STRATIGRAPHY}

By John S. SchleE

Geologists interpreting geophysical records have long attempted to correlate distinctive reflecting horizons and to give them chronostratigraphic significance (same age throughout area in which observed). Horizon A (lower Eocene), in the deep ocean basins, is one of the first of the reflectors to be so correlated (Ewing and others, 1966; Ewing and others, 1970). Other reflectors (B, B*, $\left.\mathrm{A}^{*}, \mathrm{AII}\right)$ have been used to correlate packages of reflectors across wide areas of the sea floor (Emery and others, 1970; Emery and others, 1975) in an attempt to put together the geologic history of the oceanic basins. On the continental margin, similar attempts have been made to correlate distinctive reflectors, but the results have been mainly limited to the upper second of record because of the problem of multiple reflections on single-channel reflection profiles. On the first multichannel profiles collected off the U.S. Atlantic margin, correlation of Cenozoic, Cretaceous, and preCretaceous sequences was based on changes in the acoustic character of the reflectors; horizons $(\mathrm{K}, \mathrm{Z}$, $\mathrm{X}$ ) were drawn in order to bound these distinctive groups (Schlee and others, 1976). Implicit was the assumption that these horizons approximated time lines. On the Canadian Atlantic margin, acoustic reflectors have been tied to drill-hole stratigraphy 
with a high degree of certainty by Jansa and Wade (1975a and b), Parsons (1975), and Given (1977), but these authors correlated their reflectors to key lithologic units rather than to unconformities.

The most detailed attempt to correlate key reflectors with unconformities in cores and to use the reflectors to build an acoustic stratigraphy has been made by P. R. Vail and his associates (Vail and others, 1977) for the Gulf of Mexico, San Juan basin, west Africa, the North Sea, and South America. On the basis of their analysis of seismicreflection profiles in areas where drill holes are numerous, they found that seismic reflections are returned primarily from (1) stratal surfaces and (2) unconformities characterized by sufficient velocity and density contrasts to cause a coherent return of acoustic energy (Vail and others, 1977). The stratal surfaces are time-synchronous bedding surfaces; at one time, they were surfaces of deposition that existed over a wide area. Unconformities can be used to bound groups of reflectors which are correlated with depositional sequences whose ages are estimated. Figure 36 illustrates the basic concepts of a depositional sequence as defined by R. M. Mitchum, Jr., P. R. Vail, and S. Thompson III (in Vail and others, 1977, p. 54). The relationships of strata (and reflectors) to the sequence boundaries are shown in figure 37.

The time significance of an unconformity is that all the rocks below the unconformity are older than the rocks above it (fig. 36). More importantly, the depositional sequences between major unconformities have been analyzed for coastal onlap, downlap, and toplap (illustrated in figure 37 ) to define geochronologic cycles of relative sea-level change. Some of the major unconformities appear to correlate over wide areas and may have formed at the same time worldwide. Thus, they indicate a major amount of relative sea-level drop. A table showing changes in eustatic sea level by P. R. Vail, R. M. Mitchum, Jr., and S. Thompson III (in Vail and others, 1977, p. 93) shows major shifts in sea level in the late Miocene, middle to late Oligocene, early middle Eocene, middle Paleocene, middle Cenomanian (Late Cretaceous), Valanginian (Early Cretaceous), and Sinemurian (Early Jurassic). The table also shows several older sea-level shifts that were probably earlier than the formation of the Baltimore Canyon Trough. Numerous lesser shifts also took place and would have caused the unconformities that bound smaller cyclic sequences. The major cyclic sequences would be bounded by the major unconformities formed during the times listed above.

Offshore, the seismic profiles reveal several major unconformities, particularly in the upper part of the section; for example, part of the seismic profile along line 6 is shown in figures 38 and 39. I assume that some of the offshore unconformities match up with the major unconformities reported by Vail and others (1977) and that some are local. My matches of unconformities in offshore seismic profiles with sea-level shifts shown in figure 2 and listed in table 1 of P. R. Vail, R. M. Mitchum, Jr., and S. Thompson III (in Vail and others, 1977, p. 93) indicate that major hiatuses exist in the Baltimore Canyon Trough area in the late Miocene, middle to late Oligocene, middle Paleocene, middle Cenomanian (Late Cretaceous), late Aptian (Early Cretaceous), Kimmeridgian (Late Jurassic), and Sinemurian (Early Jurassic). The units delineated by these hiatuses are lettered $\mathrm{A}-\mathrm{H}$ and are shown in figure 39 and described in table 1.

Some of the offshore unconformities (Paleocene and Oligocene) probably correlate with hiatuses detected in drill holes in the Coastal Plain, but others are not found ashore for unknown reasons. A section based on wells drilled on the Atlantic Coastal Plain (fig. 40) reveals local unconformities in the upper part of the Cretaceous of New Jersey and major unconformities, one in the Oligocene (between units $\mathrm{G}$ and $\mathrm{F}$ ) and one near the base of the Tertiary (between units $\mathrm{F}$ and $\mathrm{E}$ ); however, even the major unconformities are not apparent in the southern part of the section. Some of the older offshore unconformities might correlate with hiatuses ashore that would be in nonmarine strata of Early Cretaceous and older age (fig. 41) and thus would be difficult to document where fossils are scarce.

Only the COST No. B-2 well is available to serve as a guide to the offshore stratigraphy. Hiatuses are not evident in the stratigraphic section shown by Scholle (1977b), perhaps partly because of the sampling interval used for the paleontological study. The sampling interval (30-152 m) of rotary cuttings (subject to uphole contamination) would make checking for the completeness of a particular stage difficult.

The intervals delineated acoustically were checked with ages assigned to the rocks in the COST No. B-2 well (Scholle, 1977b). A part of seismic line 2 (fig. 1) is approximately $12 \mathrm{~km}$ southwest of the well. A comparison of unit 

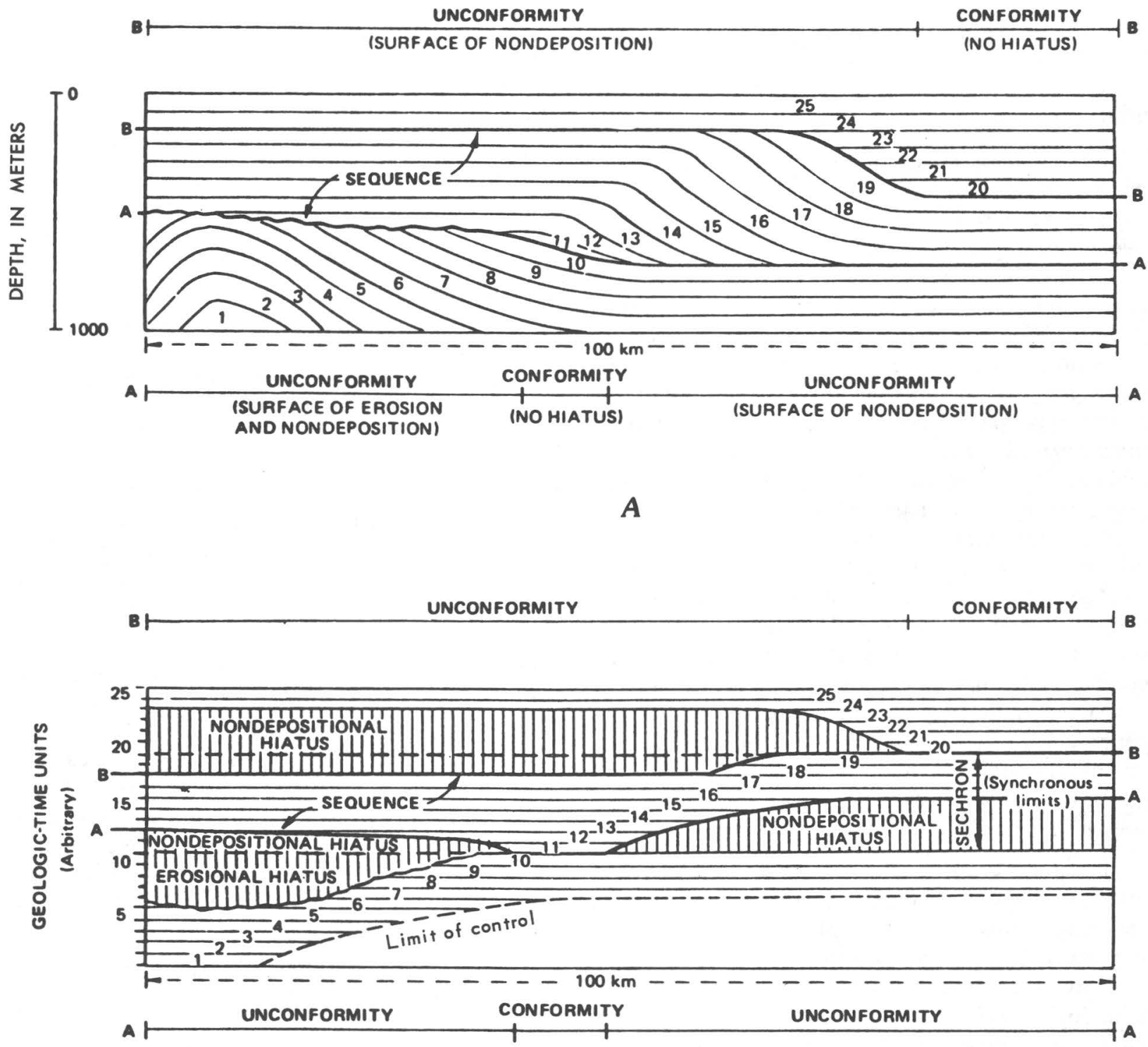

FIGURE 36. $-A$, Schematic diagram of a depositional sequence showing the different types of relations (onlap, truncation, and downlap) that can exist along the same unconformity. $B$, Reconstruction of above diagram in which geologic time is used as the ordinate. This chronostratigraphic section indicates (1) where the sedimentary record is most complete and (2) where the amount of time represented by a particular hiatus changes laterally. Both from R. M. Mitchum, Jr., P. R. Vail, and S. Thompson III (in Vail and others, 1977, p. 54), who (p. 55) defined sechron "(from se-quence and chron time) ${ }^{* * *}$ as the total interval of geologic time during which a sequence is deposited."

thicknesses determined acoustically and drilled (table 2) shows some agreement in the younger part of the section and some disparity in the older part. Eventually, when a sufficient number of deep exploratory wells have been drilled on the shelf, geologists will be able to modify the acoustic stratigraphy given in this paper and to eliminate the disparities seen in part of table 2 .
Close examination of the part of seismic profile 6 shown in figure 38 reveals at least two conspicuous unconformities in the upper part of the record which are recognizable by downlap of an oblique progradational unit and by onlap of the overlying unit. I assume these two units to be $\mathrm{F}$ and $\mathrm{G}$ (table 1; fig. 39) of early Paleocene to early Oligocene and of late Oligocene to early Miocene age, respective- 


\section{UPPER BOUNDARY}

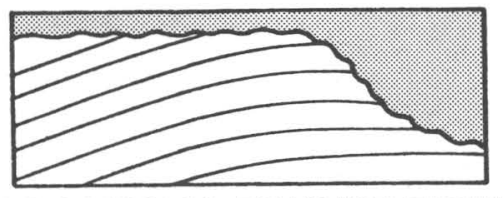

1. EROSIONAL TRUNCATION

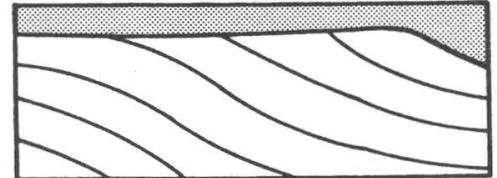

2.

TOPLAP

\section{LOWER BOUNDARY}

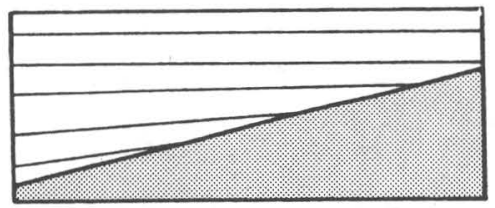

1.

ONLAP

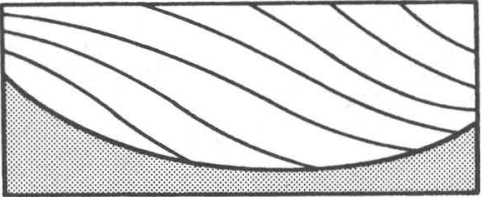

DOWNLAP

2.

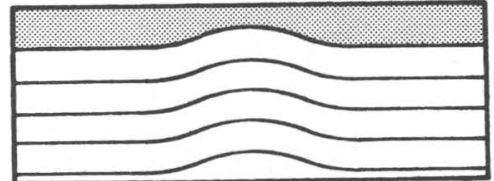

3. CONCORDANCE

BASELAP

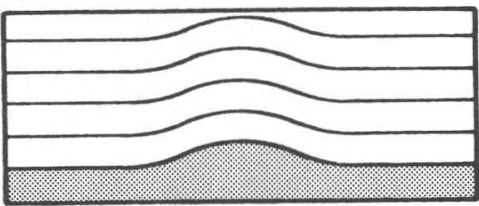

3. CONCORDANCE

Figure 37.-Possible types of stratigraphic relations found at the upper and lower bounding surfaces (unconformities and disconformities) in a depositional sequence. Both from R. M. Mitchum, Jr., P. R. Vail, and S. Thompson III (in Vail and others, 1977, p. 58).

TABLE 1.-Acoustic units delineated in the Baltimore Canyon Trough area

\begin{tabular}{|c|c|c|c|c|c|c|c|}
\hline \multirow{2}{*}{$\begin{array}{l}\text { Unit } \\
\text { designation } \\
\text { (fig. 39) }\end{array}$} & \multirow{2}{*}{ Inferred age } & \multirow{2}{*}{$\begin{array}{l}\text { External lower } \\
\text { boundary }\end{array}$} & \multicolumn{3}{|c|}{ Internal Properties } & \multirow{2}{*}{$\begin{array}{l}\text { Range of } \\
\text { interval velocities } \\
(\mathrm{km} / \mathrm{s})\end{array}$} & \multirow{2}{*}{ Seismic facies interpretation } \\
\hline & & & Configuration & Continuity & Intensity & & \\
\hline $\mathrm{H}$ & $\begin{array}{l}\text { late Miocene } \\
\text { and younger. }\end{array}$ & $\begin{array}{l}\text { Onlap; conform- } \\
\text { able; downlap. }\end{array}$ & $\begin{array}{l}\text { Parallel to low- } \\
\text { angle diver- } \\
\text { gence. }\end{array}$ & Low to high. & $\begin{array}{l}\text { Moderate to } \\
\text { high. }\end{array}$ & $1.55-1.85$ & $\begin{array}{l}\text { Open-shelf marine, contrasting high } \\
\text { energy and low energy to low } \\
\text { energy. }\end{array}$ \\
\hline G & $\begin{array}{l}\text { early Miocene } \\
\text { and late } \\
\text { Oligocene. }\end{array}$ & $\begin{array}{l}\text { Onlap; conform- } \\
\text { able; downlap. }\end{array}$ & $\begin{array}{l}\text { Parallel to } \\
\text { sigmoid. }\end{array}$ & $\begin{array}{l}\text { Low to } \\
\text { moderate. }\end{array}$ & Low to high. & $1.60-2.17$ & $\begin{array}{l}\text { Open-shelf marine, contrasting high } \\
\text { and low energy; prograding shelf- } \\
\text { edge wedges. }\end{array}$ \\
\hline $\mathrm{F}$ & $\begin{array}{l}\text { early Oligocene } \\
\text { to early } \\
\text { Paleocene. }\end{array}$ & $\begin{array}{l}\text { Onlap; conform- } \\
\text { able; downlap. }\end{array}$ & $\begin{array}{l}\text { Parallel and } \\
\text { sigmoid. }\end{array}$ & Low to high. & $\begin{array}{l}\text { Moderate to low } \\
\text { and high. }\end{array}$ & $1.87-2.60$ & $\begin{array}{l}\text { Open-shelf marine of varying energy } \\
\text { conditions, and a delta built off } \\
\text { Delaware. }\end{array}$ \\
\hline $\mathrm{E}$ & $\begin{array}{l}\text { Late Cretaceous } \\
\text { (to Ceno- } \\
\text { manian). }\end{array}$ & $\begin{array}{l}\text { Conformable; } \\
\text { some onlap } \\
\text { and downlap. }\end{array}$ & $\begin{array}{l}\text { Parallel to } \\
\text { low-angle } \\
\text { divergence. }\end{array}$ & $\begin{array}{l}\text { Moderate and } \\
\text { high. }\end{array}$ & Low to high. & $1.90-3.32$ & $\begin{array}{l}\text { Open-shelf marine of low to modest } \\
\text { energy conditions. }\end{array}$ \\
\hline $\mathrm{D}$ & $\begin{array}{l}\text { Early Cretaceous } \\
\text { (to Aptian?). }\end{array}$ & $\begin{array}{l}\text { Onlap; conform- } \\
\text { able; downlap. }\end{array}$ & $\begin{array}{l}\text { Parallel, low- } \\
\text { angle divergent } \\
\text { complex, } \\
\text { oblique, and } \\
\text { sigmoid. }\end{array}$ & $\begin{array}{l}\text { Low to } \\
\text { moderate. }\end{array}$ & $\begin{array}{l}\text { Low to } \\
\text { moderate. }\end{array}$ & $2.34-4.07$ & $\begin{array}{l}\text { Nonmarine to open-shelf marine } \\
\text { and low energy conditions. }\end{array}$ \\
\hline $\mathrm{C}$ & $\begin{array}{l}\text { Early Cretaceous } \\
\text { and Late } \\
\text { Jurassic. }\end{array}$ & $\begin{array}{l}\text { Conformable; } \\
\text { onlap. }\end{array}$ & $\begin{array}{l}\text { Parallel to low- } \\
\text { angle } \\
\text { divergence. }\end{array}$ & $\begin{array}{l}\text { Low to } \\
\text { moderate. }\end{array}$ & $\begin{array}{l}\text { Variable; low } \\
\text { to high. }\end{array}$ & $2.91-5.02$ & $\begin{array}{l}\text { Mostly nonmarine to littoral } \\
\text { marine. }\end{array}$ \\
\hline $\mathrm{B}$ & $\begin{array}{l}\text { Late Jurassic } \\
\text { to Early } \\
\text { Jurassic. }\end{array}$ & $\begin{array}{l}\text { Onlap; } \\
\text { conformable. }\end{array}$ & $\begin{array}{l}\text { Parallel and } \\
\text { divergent. }\end{array}$ & $\begin{array}{l}\text { Low to } \\
\text { moderate. }\end{array}$ & $\begin{array}{l}\text { Variable; low } \\
\text { to high. }\end{array}$ & $3.96-6.38$ & $\begin{array}{l}\text { Mixed nonmarine and evaporitic } \\
\text { restricted marine; sandy. }\end{array}$ \\
\hline A & $\begin{array}{l}\text { Early Jurassic } \\
\text { and pre-Early } \\
\text { Jurassic. }\end{array}$ & $\begin{array}{l}\text { Onlap; fault } \\
\text { boundary. }\end{array}$ & $\begin{array}{l}\text { Divergent to } \\
\text { parallel. }\end{array}$ & Low to high. & High to low. & $3.95-6.36$ & $\begin{array}{l}\text { Mixed nonmarine and restricted } \\
\text { marine. }\end{array}$ \\
\hline
\end{tabular}

ly. The breaks are apparent where layers were obviously onlapped and truncated. Less obvious are disconformities where reflectors approach the break at an extremely low angle or where the hiatus is evident by the low undulating relief of reflectors adjacent to it. The onlap relations are most obvious on cross-shelf (dip sections such as shown in fig. 38 ) oriented at right angles to the strike of sedimentary units, where the section thins in a short distance; profiles oriented parallel to the shelf also can show onlap and downlap relations, but the thinning is spread over a longer distance.

Not all acoustic units are marked by an obvious unconformity. The acoustic unit $\mathrm{H}$ (post-upper Miocene) is mainly strong, even reflectors above a 


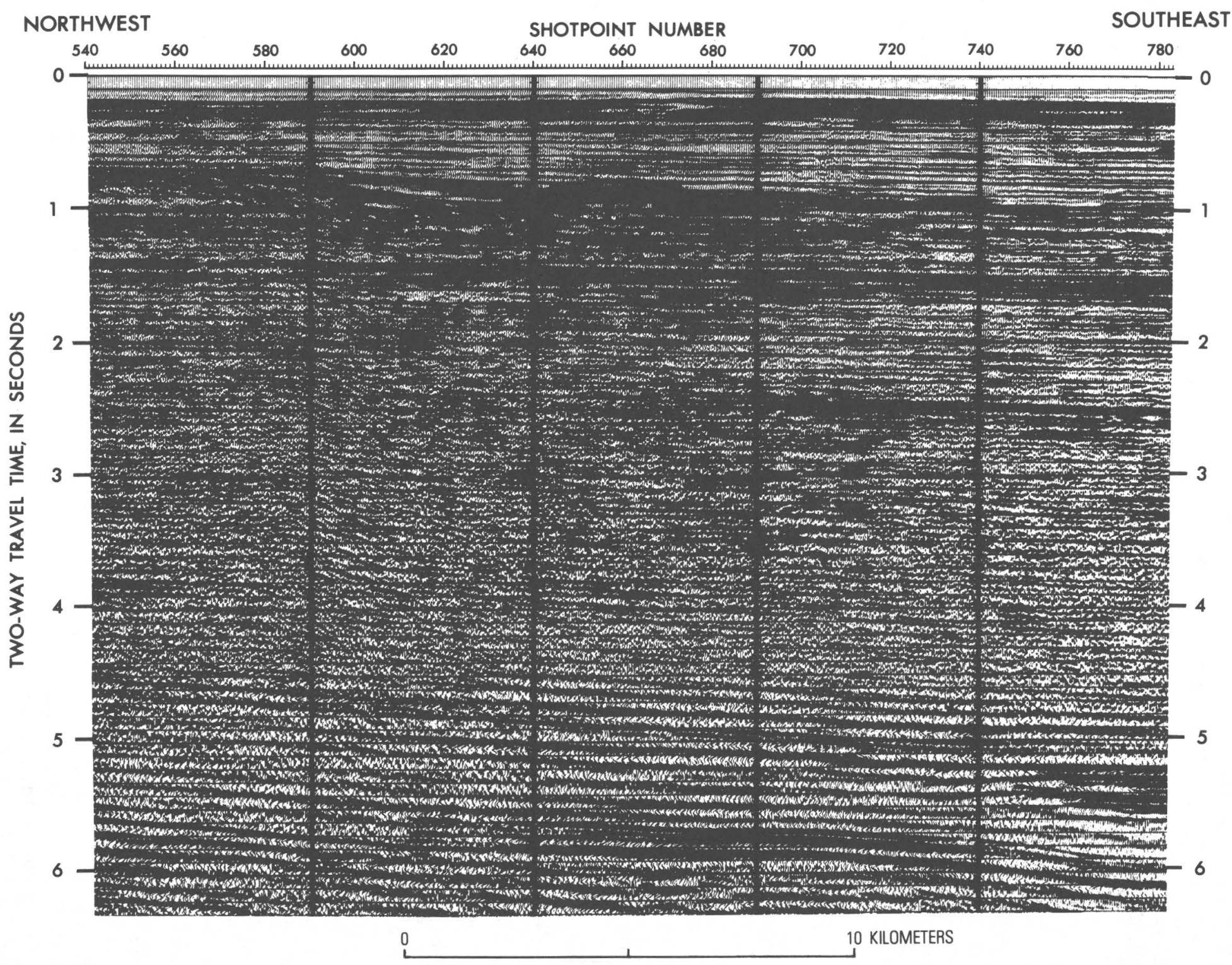

FIGURE 38. - A part of CDP multichannel seismic profile 6 off southern New Jersey (see fig. 1 for location). 


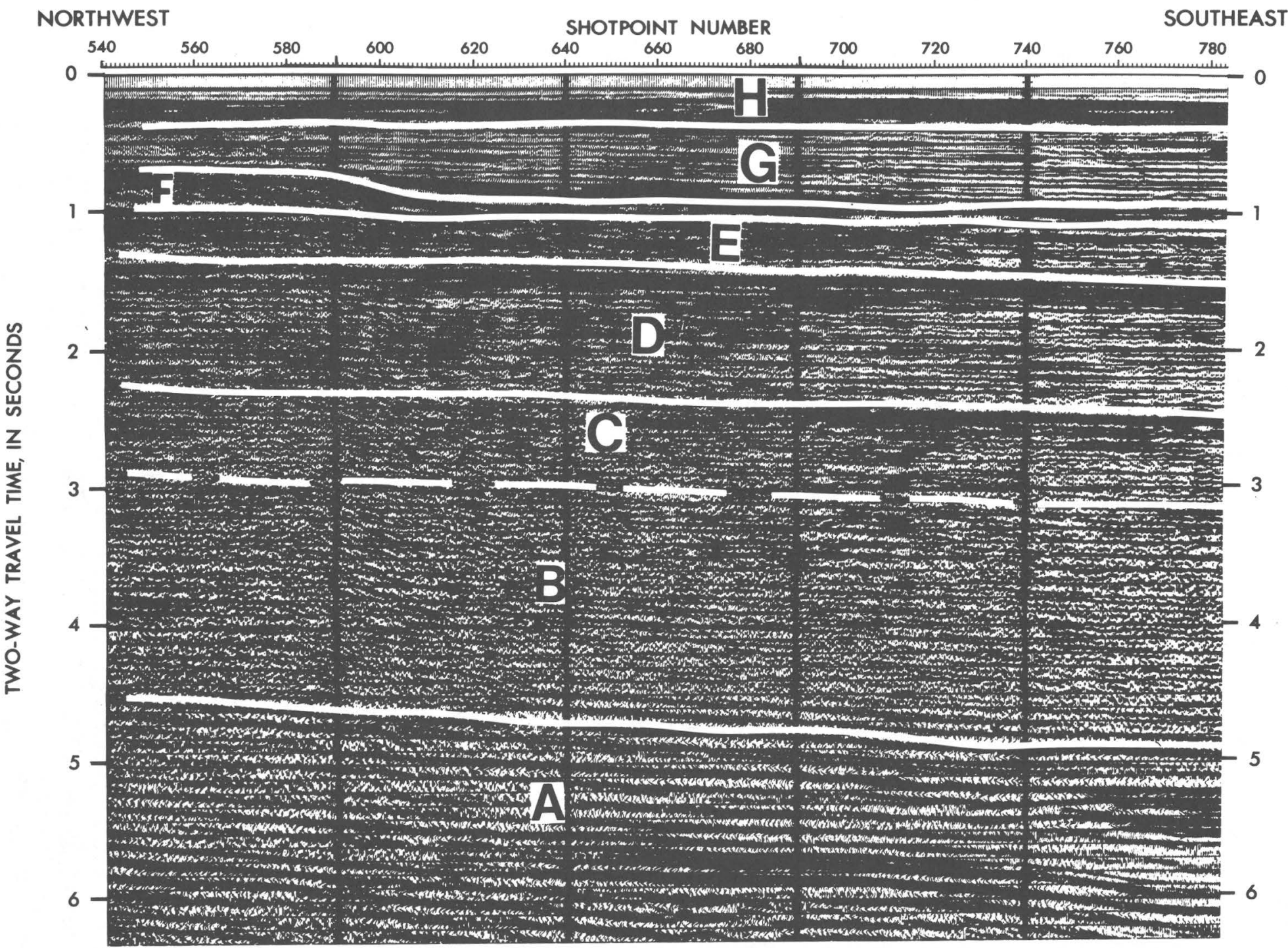

FIGURE 39. - The same part of seismic profile 6 that is shown in figure 38 but on which the acoustic units are labeled. The acoustic units are described in table 1 . Toward the top of the record can be seen broadly onlapping unit $\mathrm{G}$ and obliquely prograding unit $\mathrm{F}$. Also, the transition from inferred marine facies (high continuity and moderate to high seismic amplitude) to inferred nonmarine facies (low continuity and variable seismic amplitude) can be seen within units $\mathrm{C}$ and $\mathrm{D}$. 


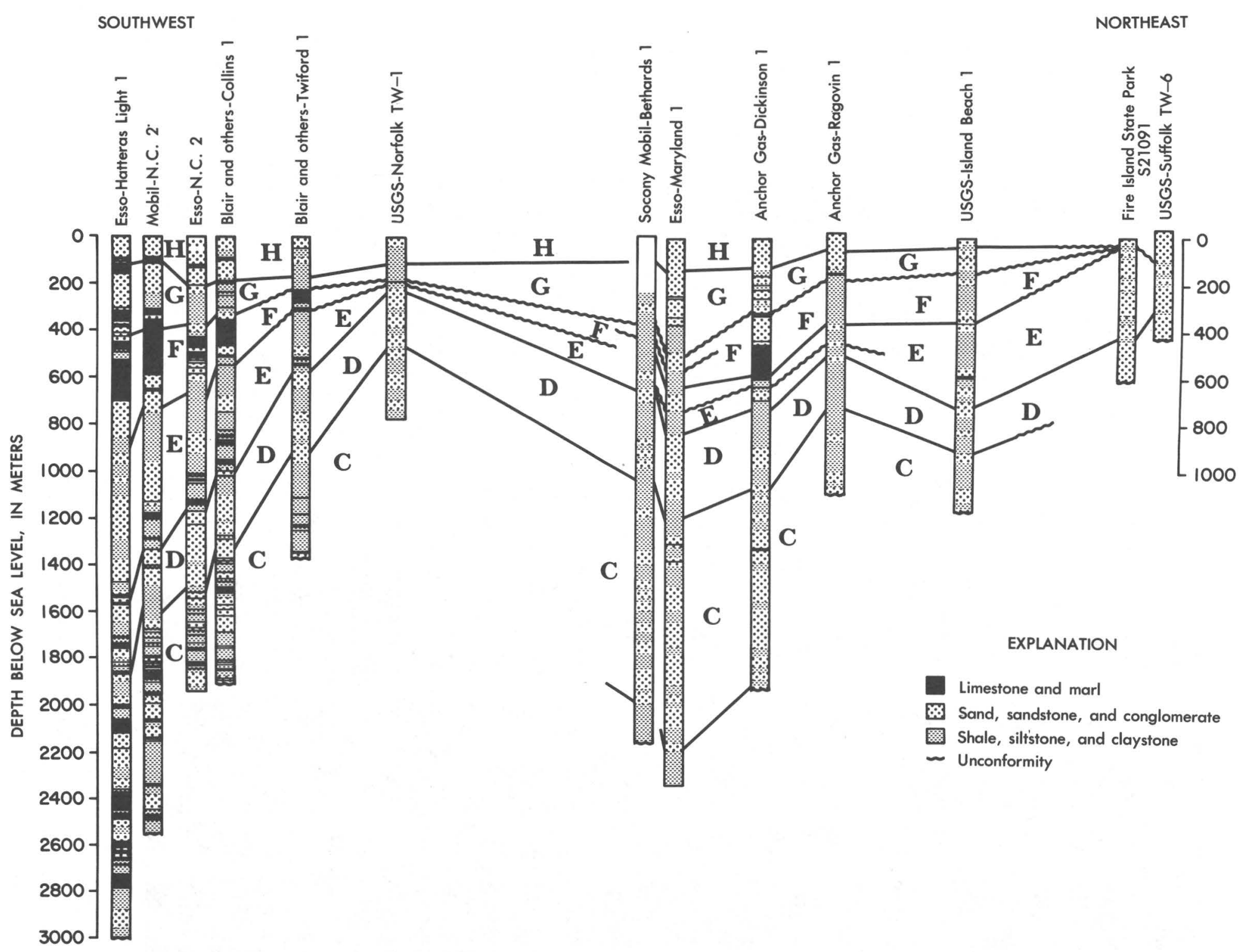

FIGURE 40.-A generalized lithologic section based on 13 holes drilled near the seaward edge of the Atlantic Coastal Plain from North Carolina to New York; these holes were described by Brown, Miller, and Swain (1972). The section shows major hiatuses and the correlation of letter-designated units described in table 1. See figs. 1 and 27 for well locations. 


\begin{tabular}{|c|c|c|c|c|}
\hline \multicolumn{3}{|c|}{ SOUTHWEST } & & \\
\hline & & & & \\
\hline$\tau$ & & & 0 & 产 \\
\hline 志 & & & ư & $\vec{z}$ \\
\hline & $\stackrel{n}{n}$ & N & 竧 & $\frac{\pi}{\Phi}$ \\
\hline $\begin{array}{l}\text { 离 } \\
\frac{\text { to }}{2}\end{array}$ & $\begin{array}{l}U \\
Z\end{array}$ & & 묻 & 욷 \\
\hline & $\frac{\overline{\frac{1}{0}}}{\frac{10}{0}}$ & $\begin{array}{l}z \\
\text { Z } \\
\text { g. }\end{array}$ & $\begin{array}{l}\overline{0} \\
\text { 흠 }\end{array}$ & 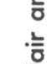 \\
\hline
\end{tabular}
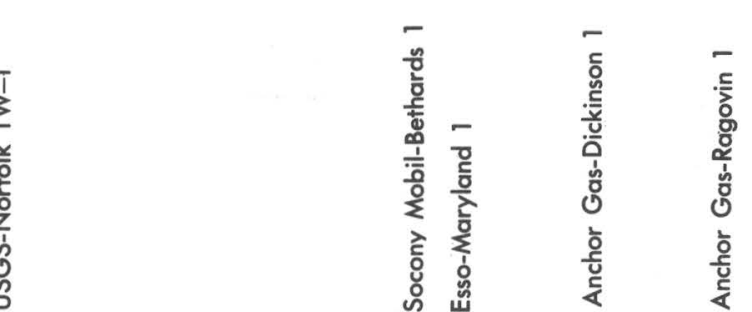

NORTHEAST
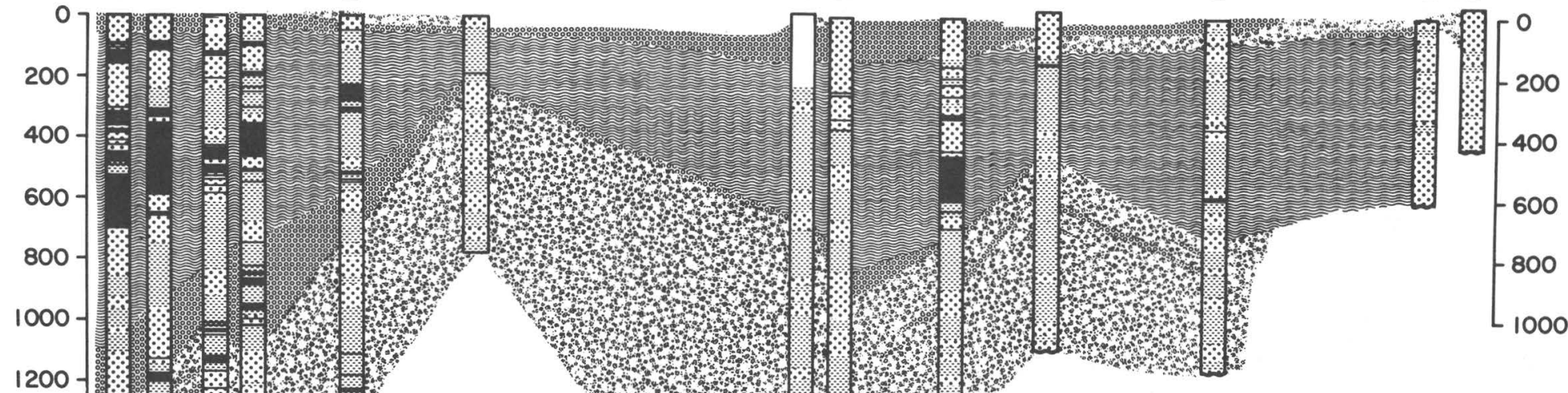

岂 1400

出

㟧

3

岗

돈

1800

2000

2200

2400

2600

2800

3000



잉

호응

듬 专

는

FIGURE 41.-Environments of deposition as represented in the generalized lithologic section in figure 40. Interpretation by C. Wylie Poag, who was unable to project environment of deposition between the two northeasternmost wells because of lack of information. 
TABLE 2. - A comparison of the thickness of acoustic units from seismic line 2 with the thickness of rocks of equivalent age in the COST No. B-2 well

\begin{tabular}{lcc}
\hline Age interval & $\begin{array}{c}\text { Thickness of } \\
\text { acoustic units } \\
\text { along line 21 } \\
\text { (kilometers) }\end{array}$ & $\begin{array}{c}\text { Thickness of } \\
\text { units penetrated } \\
\text { in the COST No. } \\
\text { B-2 well } \\
\text { (kilometers) }\end{array}$ \\
\hline $\begin{array}{l}\text { Post-middle late Oligocene } \\
\text { Middle late Oligocene to } \\
\text { middle Paleocene }\end{array}$ & 0.88 & 0.85 \\
$\begin{array}{l}\text { Middle Paleocene to middle } \\
\text { Cenomanian --- } \\
\text { Middle Cenomanian to late } \\
\text { Aptian -- }\end{array}$ & .37 & .30 \\
\hline
\end{tabular}

I The thickness of each acoustic unit is the mean calculated from the values at the two closest shotpoints as given by Digicon Geophysical Corp. on line 2.

presumably older unit that lacks strong, highamplitude, continuous reflectors (fig. 39). In a few areas, extremely low angle truncation of the older unit, G, is evident, but where the truncation is missing, the youngest unit, $\mathrm{H}$, still projects through on the basis of its acoustic character. In the lowest part of the section, the boundary at the top of unit A (Lower Jurassic to pre-Lower Jurassic) was inferred to be present at the top of the conspicuous group of reflectors 5-6 seconds below sea level in the deepest part of the basin; these reflectors can be traced widely over the Baltimore Canyon Trough and the Georges Bank basin. Further, they mark a velocity change that averages from about 4.7 to about $5.5 \mathrm{~km} / \mathrm{s}$. Similar strong reflectors are present just above acoustic basement on the Scotian Shelf where they were drilled. There they represent a sequence of halite and dolomite-part of the Argo, Iroquois, and Mohican Formations of Early to Middle Jurassic age (Given, 1977).

The acoustic units recognized in the Baltimore Canyon Trough (table 1) vary widely in acoustic character and in their boundary relations. The change in acoustic character, both laterally and vertically, was alluded to by Schlee and others (1976); the change in character is mainly in the continuity of the reflectors and in their intensity (fig. 39 ). Both these acoustic properties plus the breadth and reflector configuration have been used by J. B. Sangree and J. M. Widmier (in Vail and others, 1977, table 1, p. 166-168) to infer environments of deposition for sedimentary sequences represented by the acoustic unit. My interpretation of seismic facies present in the Baltimore Canyon Trough area (table 3 ) is based on their table.

The environments described in table 3 are mainly shelf or coastal-plain types. However, two shelfslope types (sigmoidal mound seismic facies and oblique-progradational seismic facies) are present in the Baltimore Canyon Trough area along with the other seismic facies. The main feature to typify most of these seismic facies is a general parallelism of reflectors. They may diverge in some areas because of differing rates of subsidence, and they may become discontinuous because of a presumed change in the types of sediments within the unit.

TABLE 3.-Seismic facies present in the Baltimore Canyon Trough area

[Extracted from J. B. Sangree and J. M. Widmier (in Vail and others, 1977, table 1, p. 166-168)]

\begin{tabular}{|c|c|c|c|c|}
\hline Seismic facies unit & $\begin{array}{l}\text { Interpreted environment } \\
\text { of deposition }\end{array}$ & $\begin{array}{l}\text { External form of } \\
\text { seismic unit }\end{array}$ & Internal configuration & $\begin{array}{l}\text { Reflection geometry } \\
\text { at boundaries }\end{array}$ \\
\hline Low continuity and variable amplitude & $\begin{array}{l}\text { Nonmarine-river and associated } \\
\text { marginal marine transport processes. }\end{array}$ & Sheet or wedge & Parallel to divergent _-_-_ & $\begin{array}{l}\text { Concordant at the top and con- } \\
\text { cordant to gentle onlap and } \\
\text { downlap at base. }\end{array}$ \\
\hline High continuity and high amplitude & $\begin{array}{l}\text { Shallow open marine shelf having } \\
\text { wave transport; high- and lowenergy } \\
\text { conditions; possible fluvial deposits } \\
\text { interbedded with marsh deposits. }\end{array}$ & Sheet or wedge & Parallel to divergent _---- & $\begin{array}{l}\text { Concordant at top and concordant } \\
\text { to gentle onlap and downlap at base. }\end{array}$ \\
\hline Low amplitude _-_- & $\begin{array}{l}\text { Sand: fluvial and nearshore littoral } \\
\text { processes. } \\
\text { Shale: marine shelf sediments de- } \\
\text { posited under low-energy regime } \\
\text { from turbidity currents and by } \\
\text { wave transport. }\end{array}$ & Sheet or wedge & Parallel to divergent _-_-_ & $\begin{array}{l}\text { Discordant at top and concordant } \\
\text { to gentle downlap or onlap at } \\
\text { base. }\end{array}$ \\
\hline $\begin{array}{l}\text { Moderate continuity and low to } \\
\text { moderate amplitude. }\end{array}$ & $\begin{array}{l}\text { Open neritic shelf having low to } \\
\text { modest energy conditions. }\end{array}$ & & & $\begin{array}{l}\text { Concordant or low-angle truncation at } \\
\text { top; concordant or onlap at the base. }\end{array}$ \\
\hline Sigmoid, low-relief mound & Shelf delta complex & $\begin{array}{l}\text { Low broad } \\
\text { mound. }\end{array}$ & $\begin{array}{l}\text { Sigmoid along deposi- } \\
\text { tional dip; reflectors } \\
\text { onlap and form an } \\
\text { augen shape parallel to } \\
\text { depositional strike. }\end{array}$ & $\begin{array}{l}\text { Concordant at top and downlap and } \\
\text { onlap at base. }\end{array}$ \\
\hline Oblique-progradational __------_--- & $\begin{array}{l}\text { Shelf-slope boundary; variable energy } \\
\text { conditions from high energy in top- } \\
\text { lap-truncated area to low energy in } \\
\text { clinoform and fondoform (prodelta } \\
\text { zones). }\end{array}$ & Fan-shaped_----- & $\begin{array}{l}\text { Parallel in upper part; } \\
\text { oblique along deposi- } \\
\text { tional dip and parallel } \\
\text { or gently oblique to } \\
\text { sigmoid parallel to } \\
\text { depositional strike. }\end{array}$ & Toplap truncation to downlap at base. \\
\hline
\end{tabular}


The seismic facies described in table 3 are distinguished mainly on the basis of the continuity of their reflectors, the intensity (amplitude) of the reflector, the breadth of the reflector, and the geometry (shape) of the unit; a discussion and table of all units (deep water as well as shelf) are given by J. B. Sangree and J. M. Widmier (in Vail and others 1977, table 1, p. 166-168). They based their environmental inferences on drill-hole data keyed to multichannel seismic-reflection profiles collected in the same area.

From this correlation of geophysical information and stratigraphy, several principles emerge. High continuity of reflectors is used to indicate a contrast in depositional energy conditions operating over a wide area. These conditions are mostly to be expected on a broad shelf having both high- and low-energy states that result in the deposition of interbedded sandstone, limestone, or shale. Agents of active sediment transport would probably be waves and currents on the shelf. Sangree and Widmier (in Vail and others, 1977, p. 166-168) also noted that a high continuity of reflectors can also characterize deposits of broad swampy coastal-plain areas in which fluvial sands are bedded with widespread coal and marsh clays. Conversely, low continuity of reflectors indicates the presence of lithologic units of limited areal extent, such as discontinuous channel sands bedded with flood-plain clays in an alluvial plain. To recognize this type of an environment, both the seismic amplitude and the continuity of reflectors are needed.

Seismic amplitude provides a qualitative guide to the density contrast of adjacent reflectors. Coupled with low reflector continuity, variable amplitude is used to infer that sequences are nonmarine; nonmarine sequences commonly contain small channel sands that contrast strongly in density with adjacent clays so that high-amplitude reflections can result. Interbedded silt may provide less contrast to the clay. Thus, nonmarine sequences tend to be characterized by reflectors having low continuity and variable amplitude (table 3 ). Low-amplitude reflections or the absence of reflections suggests sedimentary rocks of a uniform lithology-commonly sandstone or shale. To choose between the two lithologies is difficult unless the relationships to adjacent facies can be discerned.

Across a depositional basin, the normal progression of environments is from an alluvial plain-coastal marsh, through a sandy littoral zone across a marine shelf, into deeper parts of the basin. In the deeper parts of the basin, conditions are more uniform (less amplitude variation), and the energy of depositional processes can be low (lack of reflector continuity). Obviously, in mapping these facies on a grid of seismic-reflection profiles, the interpreter must establish the paleogeography; then, potentially confusing facies (and associated lithologies) can be sorted out. A uniformly thick sequence of sandstone deposited in a littoral environment can be expected to grade seaward to marine shelf deposits (high continuity and high amplitude or moderate continuity and low to moderate amplitude) and to grade shoreward to nonmarine deposits (low continuity and variable amplitude). A uniform shale deposited in a shelf basin offshore could be expected to grade laterally into normal marine-shelf sandstones and shale toward the basin edge and, possibly, into prograded slope deposits (chaotic fill; mounded onlapping fill, fan complex) in a basinward direction.

The internal arrangement of reflectors is also an important guide to distinguishing environment of deposition. Most units associated with the shelf or subaerial coastal plain have a parallel to low-angle divergent arrangement of reflectors. But, where the sediments are deposited at the shelf edge or as a delta, then a sigmoid pattern of reflectors (perpendicular to depositional strike) is possible. If high-energy conditions have affected a part of the delta, the shallow-water part of it may be eroded so that an oblique progradational pattern can result because of the truncation of the fondoform beds (Rich, 1951). Parallel to the depositional strike, the delta can show a mounded arrangement of reflectors.

The broad progradational arrangement of reflectors is also present in shelf-edge deposits. Normal to depositional strike, the reflectors can show the same sigmoid or oblique progradational arrangement found in deltas, depending on energy conditions at the shelf edge; obviously a major sea-level drop could strongly affect energy conditions at the shelf edge and thereby erode the undaform beds to create an oblique progradational pattern of reflectors. Laterally along the shelf edge, these deposits could be expected to grade into other shelf or upper-slope deposits. Shoreward from the shelf edge, they could grade into normal marine-shelf deposits (parallel; high continuity; high amplitude to low amplitude); in a seaward direction, they could grade into hemipelagic or mass-movement deposits of the Continental Slope. 
The acoustic units (table 1) have been carried across the Baltimore Canyon Trough in order to estimate thickness and the environment of deposition (fig. 42). As shown on figure 42, deeper reflectors thicken and disappear in an offshore direction (southeast). Beneath the Continental Shelf, interval velocities for the various acoustic units increase in a seaward direction and as depth increases (Grow and Klitgord, this volume; Schlee and others, 1976; Grow and Schlee, 1976). The loss of deeper reflectors and the increase of interval velocity offshore have been interpreted (Schlee and others, 1976) as a facies change to carbonate rocks in the older part of the section.

\section{ACOUSTIC UNITS}

The oldest acoustic unit (A) is assumed to include strata deposited during the Late Triassic and early part of the Jurassic (fig. 43). The strata unconformably overlie an irregular basement probably consisting of block-faulted continental crust rifted during the last opening of the Atlantic Ocean. On most cross-shelf profiles, acoustic basement is easily discernable under the inner part of the Continental Shelf where it deepens rapidly to more than $9 \mathrm{~km}$ off New Jersey (fig. 44).

The upper limit of acoustic unit A is taken as a group of high-amplitude continuous reflectors assumed to represent carbonate and evaporite beds. Interval velocities below this boundary average about $5.5 \mathrm{~km} / \mathrm{s}$ and those above the boundary about $4.7 \mathrm{~km} / \mathrm{s}$.

Given (1977) showed a conspicuous group of reflections just above acoustic basement under the northern Scotian margin. The reflections are from part of the Mohican Formation, a sequence of continental clastic and evaporite deposits and dolomites of Early Jurassic age. The similarity in appearance, position in the section, and range of velocity values between the reflectors that mark the top of acoustic unit A in the Baltimore Canyon Trough and the reflectors from the Scotian margin, suggests that Unit $A$ and part of the Mohican are equivalent units. As can be seen from figure 44, unit A pinches out south of line 11, where basement rocks are probably only $3.5 \mathrm{~km}$ below sea level. To the northeast of line 11 , it thickens to more than $5 \mathrm{~km}$ (fig. 43) off central New Jersey. In some areas like the Long Island platform, the pinchout is irregular because the unit is contained within several fault troughs; basins between seismic lines 2 and 9 are inferred from aeromagnetic data (Klitgord and Behrendt, 1979).

Both nonmarine and restricted-marine conditions appear to have prevailed during deposition of unit A. Strong continuous reflectors (those having high interval velocities) are above discontinuous reflectors of variable amplitude and breadth. No strata this old have been drilled in any offshore U.S. A.tlantic holes (Scholle, 1977b; Weed and others, 1974); hence, inferences about them are mainly from the Canadian offshore holes (McIver, 1972; Given, 1977). Evidence of evaporite deposits in unit $\mathrm{A}$ in the Balitmore Canyon Trough area comes from seismic line 14 collected in late 1977. This record shows a prominent salt (?) diapir that reaches from unit $A$ to within about $1 \mathrm{~km}$ of the sea floor.

Unit B is thought to include both nonmarine and transitional rocks of Jurassic age, to be more than $3 \mathrm{~km}$ thick in the central part of the Baltimore Canyon Trough, and to have a range of interval velocities of $3.7-6.4 \mathrm{~km} / \mathrm{s}$ (fig. 45). It conformably overlies unit A and broadly onlaps the acoustic basement. Toward land, unit B is in turn onlapped by the overlying unit, as shown on the shoreward ends of the cross-shelf seismic profiles. Elsewhere, the unit is in apparent conformity with the overlying sequence. Internal configuration of reflectors in unit $B$ is parallel except at the inshore parts of cross-shelf profiles, which show a low-angle seaward divergence of reflectors.

Within the Baltimore Canyon Trough, the thickness of unit B exceeds $3 \mathrm{~km}$ under the outer shelf off southern New Jersey (fig. 45). It pinches out toward the Long Island platform and inner shelf adjacent to the coast farther south. It is more broadly distributed than unit $\mathrm{A}$, and it thickens more uniformly than does the older unit. This change in the arrangement of the thickness contours suggests that the trough may have altered its pattern of subsidence, from one mainly dominated by fault troughs of limited areal extent to one of trough-wide subsidence, as the second phase of margin formation (postrifting) began.

The low to moderate continuity of reflectors in unit $B$ and their variable amplitude suggest mainly a nonmarine sequence along the periphery of the trough (fig. 45). Some continuous, high-amplitude reflectors are interspersed with the main group of reflectors in the southern part of the trough, and these reflectors are interpreted as interbedded 


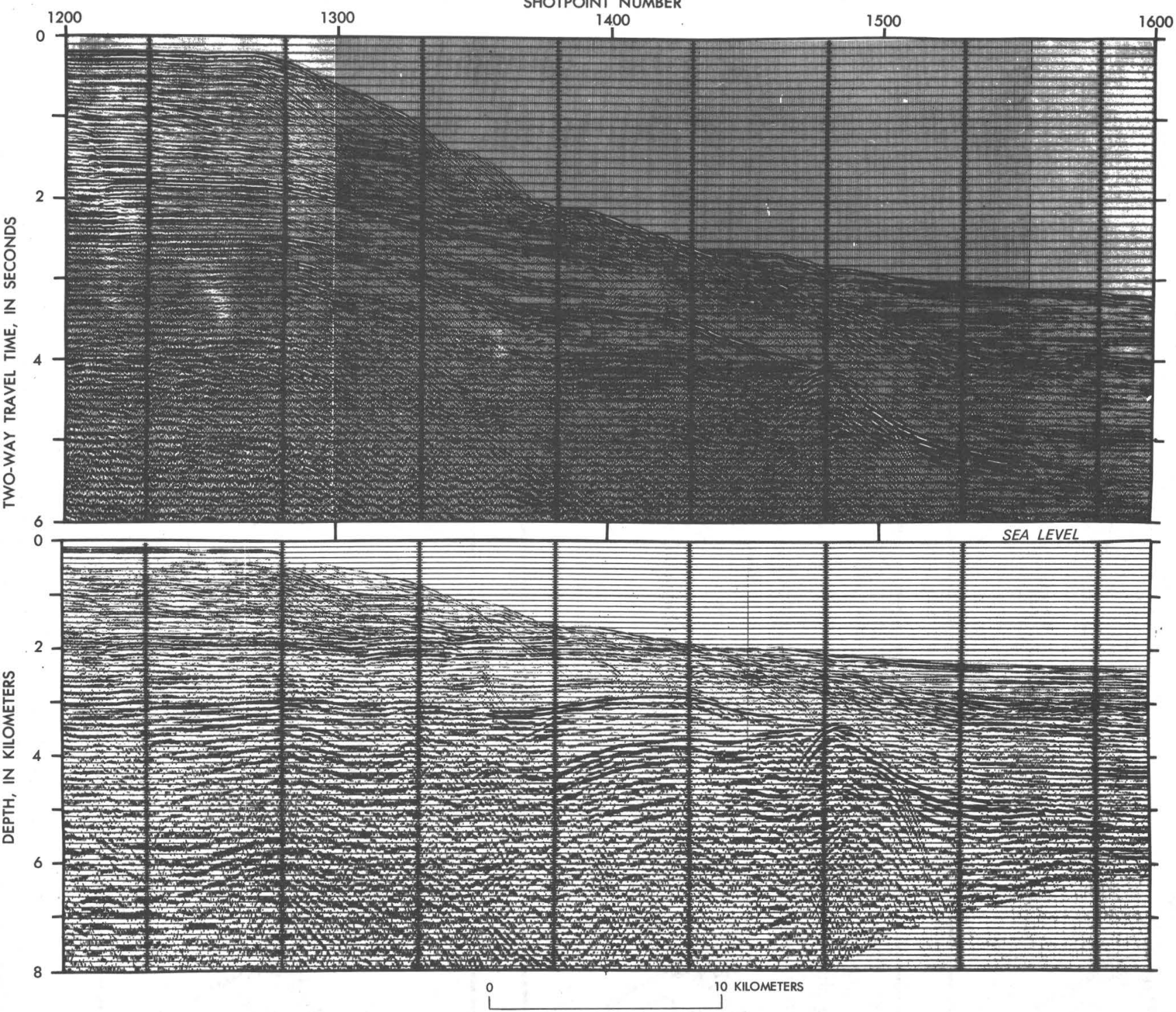

FIGURE 42. - The depth and time section of USGS seismic line 6 under the seaward edge of the Continental Shelf, Continental Slope, and upper Continental Rise (from Grow and others, 1979). Note how deep reflectors on the time section become back-tilted when the section is converted to depth. The shelf sedimentary prism is probably built across a jumble of deeply buried fault blocks under the slope and rise. 




A



B

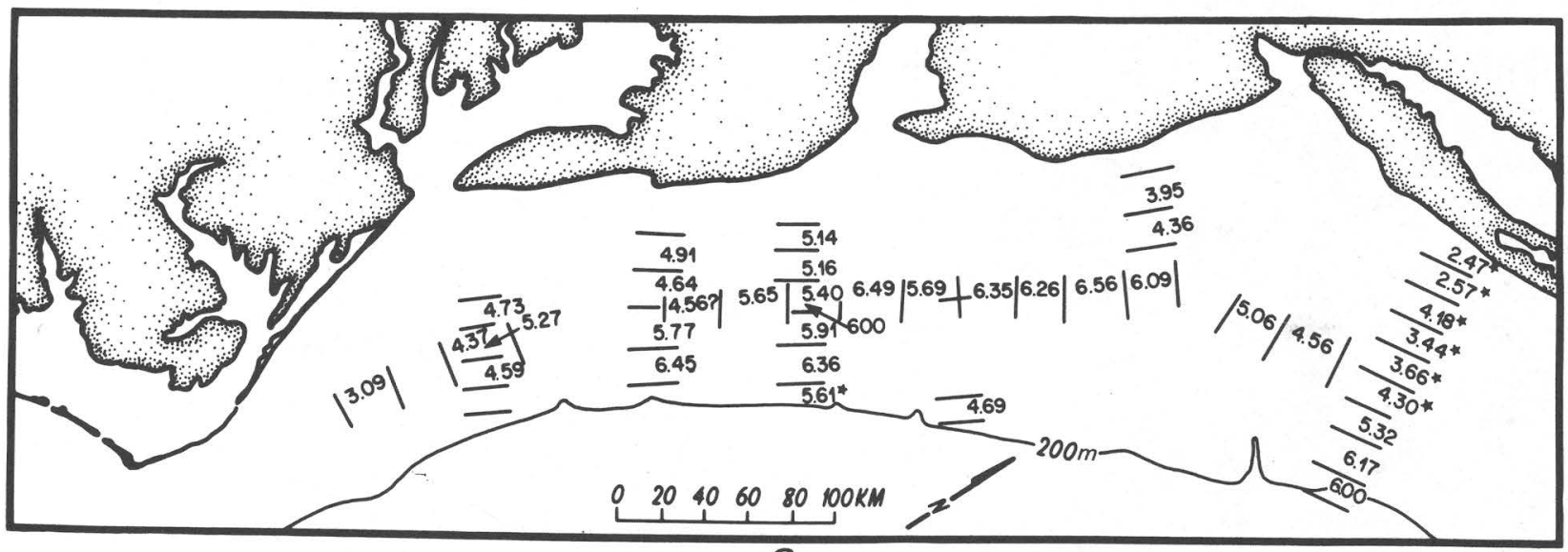

C

Figure 43. - Maps showing characteristics of unit A (see fig. 39) in the Baltimore Canyon Trough area. $A$, Thickness, in kilometers. $B$, Depositional environment; numbers represent USGS seismic lines shown in figure 1. $C$, Averaged interval velocity, in kilometers per second. The dots indicate control for thickness. Contours are dashed where seismic data were difficult to interpret. Velocity values are the arithmetic mean of values at 3-5 shotpoints between the black lines. Note irregular distribution of the unit in the northern part of the trough. Data on thickness of unit A inshore between seismic lines 2 and 9 were modified from aeromagnetic data supplied by K. D. Klitgord (USGS, Woods Hole, Mass.). Asterisked (*) interval velocities were calculated for areas where the boundaries of the unit were difficult to pick; these values, therefore, are only approximate. 


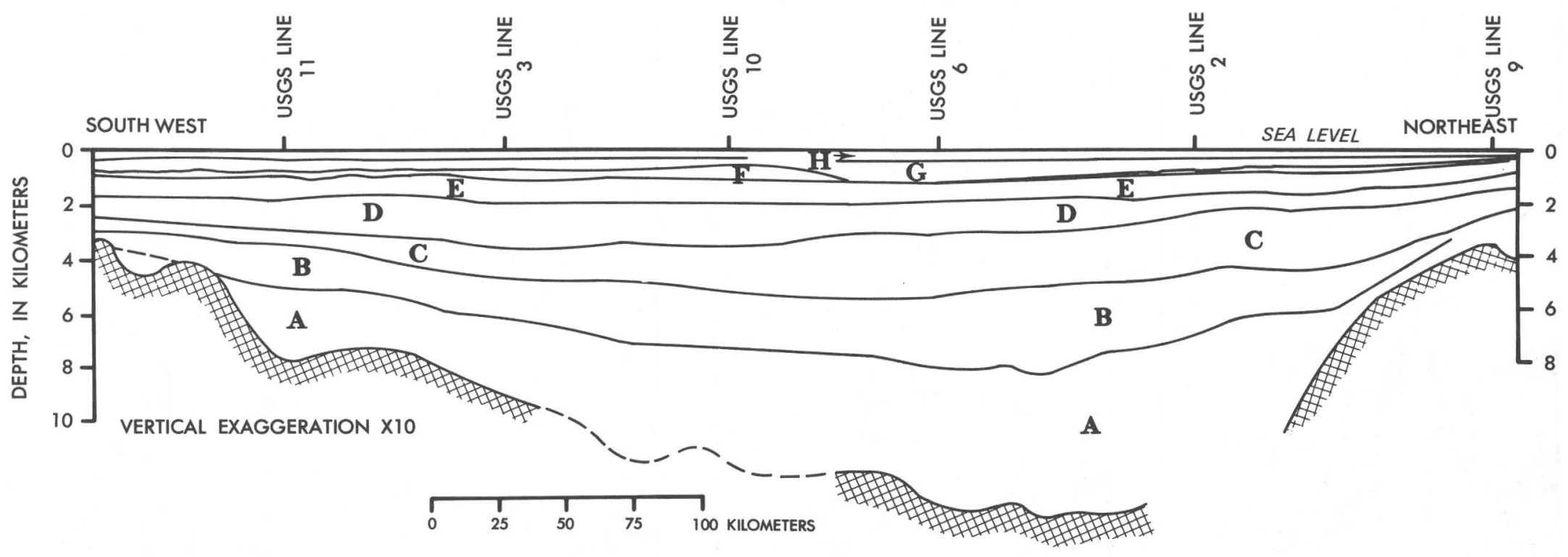

FIGURE 44. - A depth section along seismic line 12 (see fig. 1 for location) parallel to the coast. The line traverses the shelf from Virginia to New York and shows the deepening from southwest to northeast in the Baltimore Canyon Trough; maximum depth is off New Jersey. Letters refer to the depositional sequences shown in figure 39 and described in table 1. Cross-hatched areas represent basement rocks. Seismic horizons are dashed where inferred. 


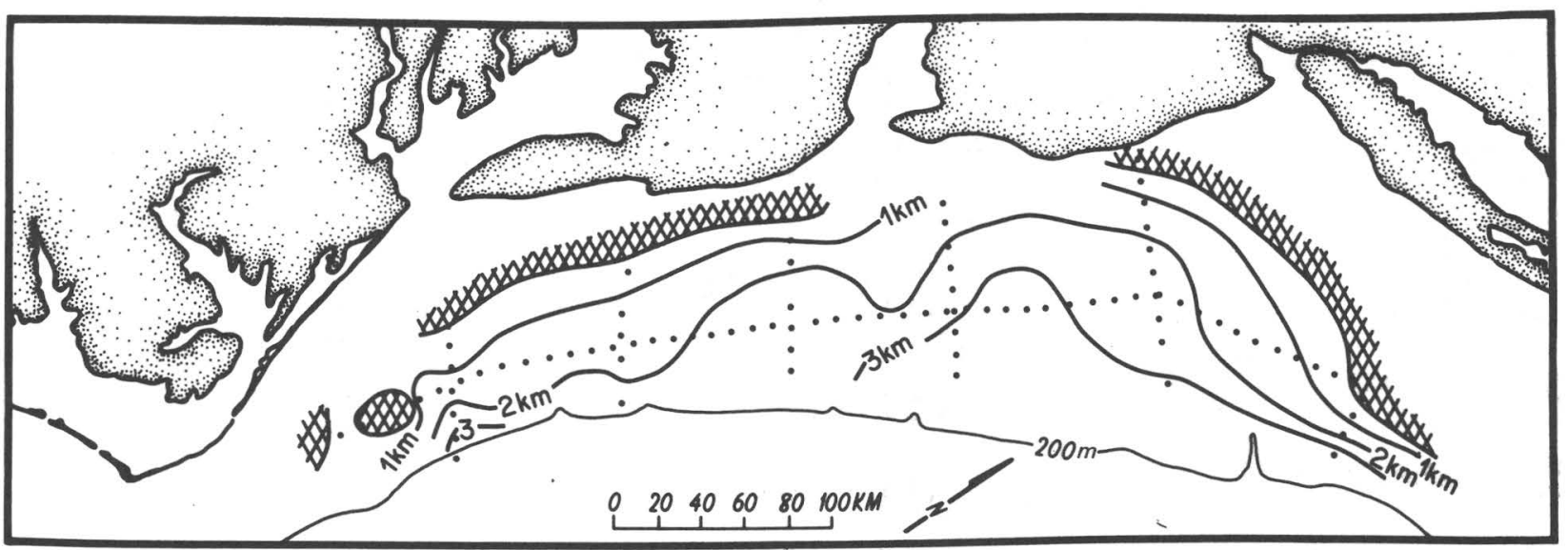

A



B

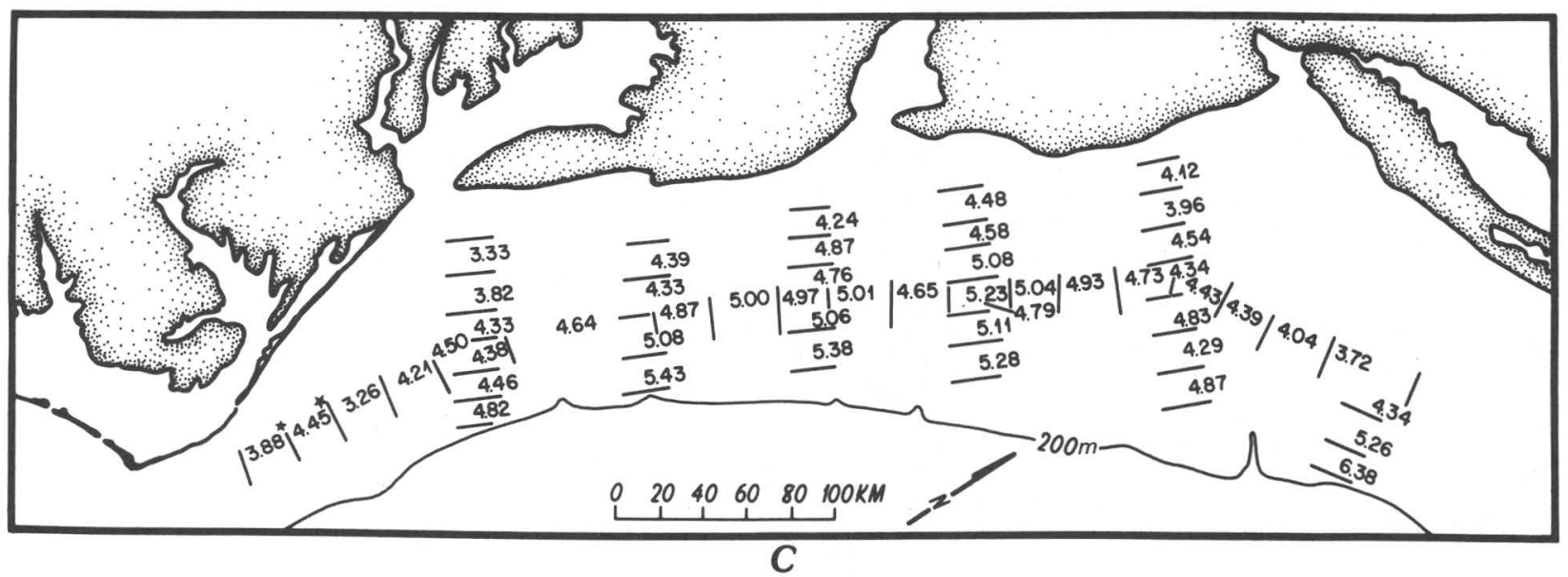

FIGURE 45.-Maps showing characteristics of unit B (see fig. 39) in the Baltimore Canyon Trough area. $A$, Thickness, in kilometers. $B$, Depositional environment. $C$, Averaged interval velocity, in kilometers per second. In $A$, the dots indicate control for thickness, and the cross pattern shows areas where unit B is missing. Dashed line in $B$ shows approximate location of shoreline during deposition of unit B; numbers represent USGS seismic lines shown in figure 1 . In $C$, velocity values are the arithmetic mean of values at 3-5 shotpoints between the black lines. Asterisked (*) interval velocities were calculated for areas where the boundaries of the unit were difficult to pick; these values, therefore, are only approximate. 
dolomites and evaporite deposits. Continuous highamplitude reflectors also are present toward the outer edge of the shelf in the upper part of unit B and merge with a lens-shaped mass under the slope. On line 2, this lens-shaped mass has been interpreted as a carbonate reef (Schlee and others, 1976, fig. 11). In much of the northern part of the trough, however, reflectors within unit B tend to lack continuity and have a low amplitude-a characteristic of either predominantly sand or predominantly shale sequences. A predominantly sand sequence is inferred because the area where it dominates the unit is between a probable nonmarine phase of the unit to the west and a more marine phase to the east (fig. 45). Presumably, the predominantly sand sequence represents a transitional-littoral facies that formed a broad sand plain adjacent to a narrow Atlantic ocean.

Unit B has not been drilled in the study area; hence, the closest information on stratigraphic units of equivalent age is in the Scotian basin, $1,000 \mathrm{~km}$ to the northeast. Here, Given (1977, p. 68) described an "Early-Middle Jurassic section of halite, dolomite and interbedded clastics"; the section consists of part of the Argo, Iroquois, and Mohican Formations. In the Scotian basin, the Mohican Formation grades up into the Scatarie Member of the Abenaki Formation, a sequence of oolitic and pelletoidal limestone, of Middle Jurassic age, which Given (1977) interpreted as the first broad marine transgression into the northern Scotian basin. In the Middle to Late Jurassic, nonmarine (deltaic and fluvial clastic rocks) facies were deposited on the inner half of the Scotian Shelf (Mic Mac Formation and Mohawk Formation). Carbonate rocks, plus deeper marine shales and sands (Baccaro Member of Abenaki Formation), were deposited under the present outer shelf and upper slope. The carbonate banks were discontinuous features, in part, because of the influx of terrigenous clastic sediments from three deltas.

The overlying unit (C), which bridges the Jurassic-Cretaceous boundary, appears to be mainly nonmarine and to be as much as $3 \mathrm{~km}$ thick in the northern part of the Baltimore Canyon Trough (fig. 46). Within unit $\mathrm{C}$, reflectors tend to be parallel or divergent at a low angle. At the base, reflectors can onlap older units, though on many profiles, the boundary is a disconformity having conformable reflectors above and below. The upper boundary of unit $\mathrm{C}$ shows both onlap and downlap by the overlying unit, particularly on the Long Island platform. In much of the rest of the trough, reflectors in the upper part of unit $\mathrm{C}$ are conformable with those in the unit above. On the seaward ends of several cross-shelf lines, the upper part of unit $\mathrm{C}$ is characterized by fairly continuous reflectors of high to moderate amplitude. These probably represent limestones (Schlee and others, 1976; Sheridan, 1976).

Unit $\mathrm{C}$ thickens to more than $3 \mathrm{~km}$ in the northern part of the trough. It appears to pinch out toward the New York Bight and to thin more gradually to the southwest (Virginia-Cape Hatteras area); locally it is thinned adjacent to an intrusive body (the Great Stone dome) off central New Jersey. For unit C also, the area of subsidence is broad adjacent to the inner shelf east of the Chesapeake Bay, though not as broad as in the underlying unit (B).

Interval velocities of unit $C$ (fig. 46) are mainly between 3 and $4.5 \mathrm{~km} / \mathrm{s}$, and the values tend to be higher offshore in the area where the unit is inferred to be either marine-shelf deposits or a sand facies. Most of the lower values are associated with nonmarine facies except at the seaward end of line 9 . The velocity values for the nonmarine sequences are in the range of 2.9 and $4.5 \mathrm{~km} / \mathrm{s}$; therefore, this interval could include well-indurated sandstone and shale having bulk densities of $2.3-2.5 \mathrm{gm} / \mathrm{cm}^{3}$ (Gardner and others, 1974). The only offshore stratigraphic information for this interval comes from the COST No. B-2 well (Smith and others, 1976), where velocities were in the range of 3.7-4.5 $\mathrm{km} / \mathrm{s}$ and the rocks drilled consisted mainly of interbedded sandstone, shale, and siltstone and scattered beds of limestone and lignite; these beds were deposited mainly in a nonmarine and transitional inner-shelf environment.

The overlying unit (D) is inferred to represent the stratigraphic interval from the upper part of the Aptian Stage to the middle part of the Cenomanian Stage (upper part of the Lower Cretaceous and lower part of the Upper Cretaceous) and to show a change to more widespread marine conditions in the Baltimore Canyon Trough (fig. 47). Reflectors in Unit D adjacent to its lower boundary onlap toward the coast, but mainly, they are conformable with those in the unit below. Some channeling by basal reflectors marks the unconformity at the base of unit D, but channeling is even more evident at the upper boundary of this unit. Even here, however, this unit tends to be conformable with the overlying sequence except near the southern part of the trough (inshore part of line 11) and near the Long Island platform (line 9), where 


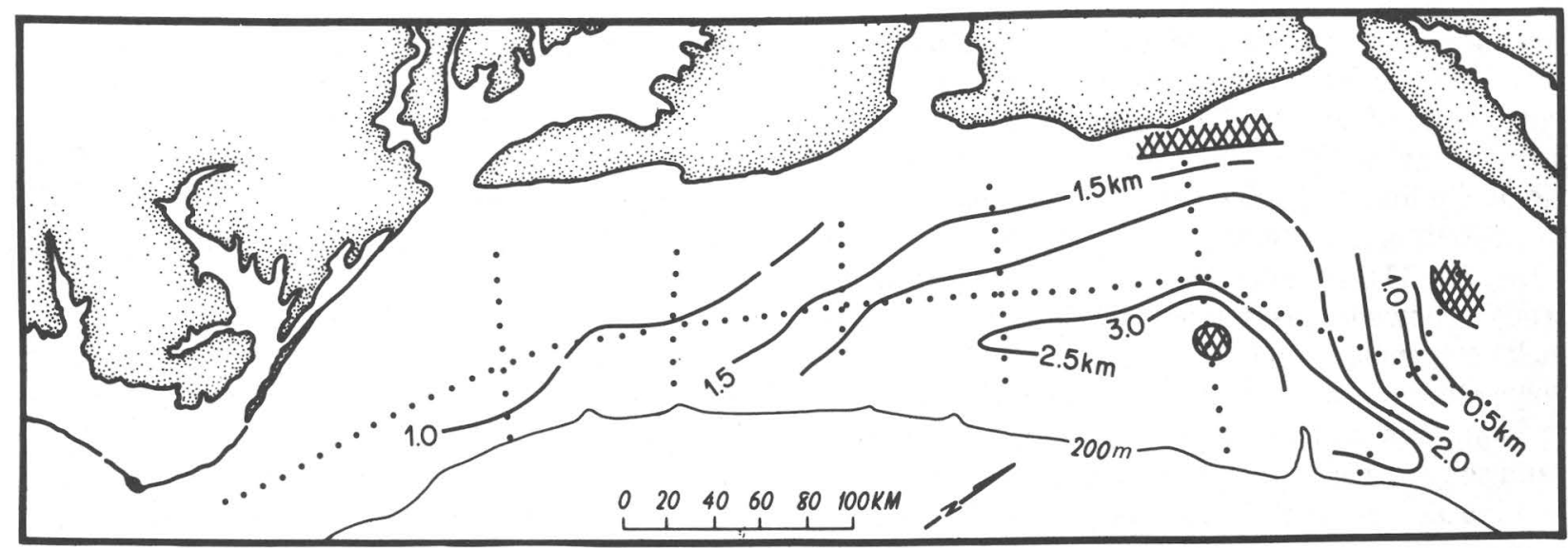

A

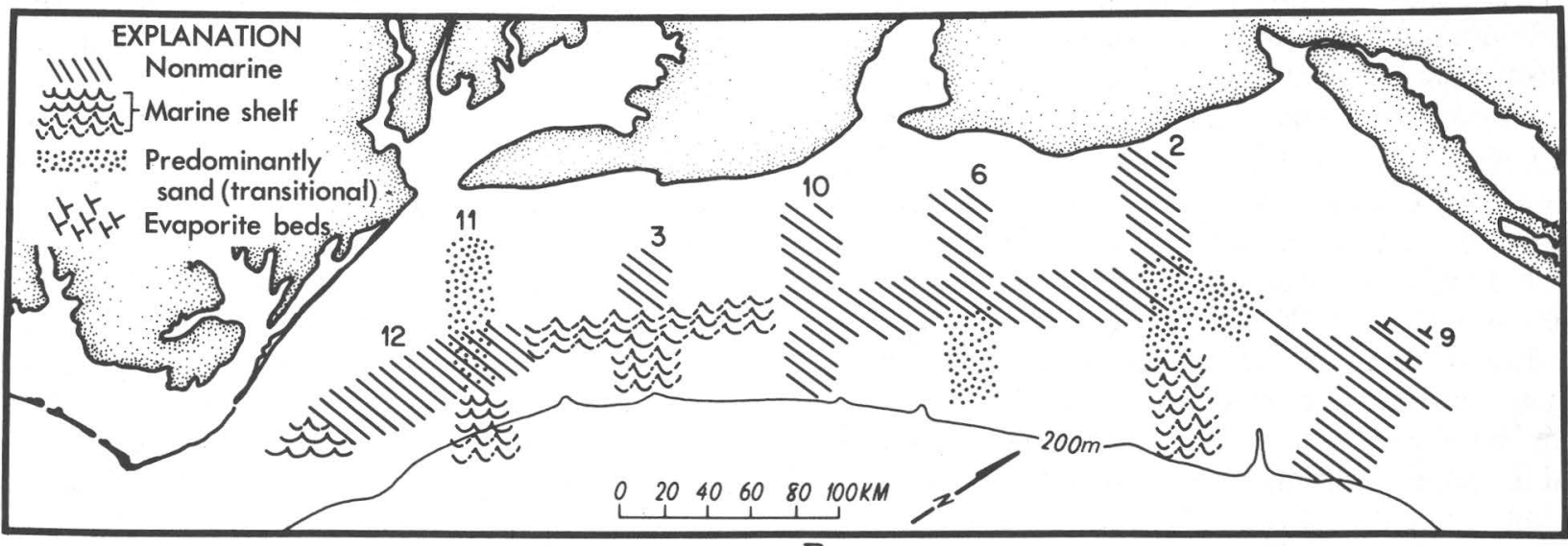

B

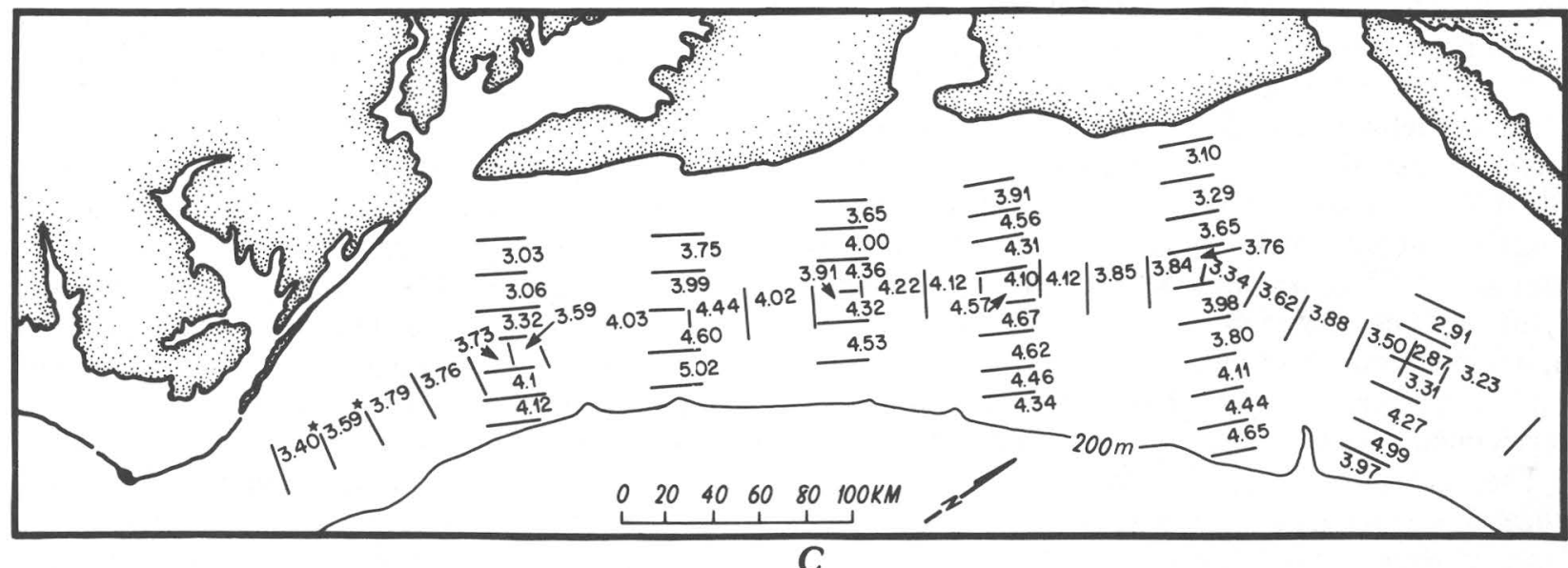

FIgURE 46. - Maps showing characteristics of unit C (see fig. 39) in the Baltimore Canyon Trough area. $A$, Thickness, in kilometers. $B$, Depositional environment. $C$, Averaged interval velocity, in kilometers per second. In $A$, the dots indicate control for thickness and the cross pattern indicates areas where unit $C$ is missing. Contours are dashed where seismic data were difficult to interpret. In $B$, numbers represent USGS seismic lines shown in figure 1 . In $C$, velocity values are the arithmetic mean of values at 3-5 shotpoints between black lines. Asterisked $\left(^{*}\right)$ interval velocities were calculated for areas where the boundaries of the unit were difficult to pick; these values, therefore, are only approximate. 

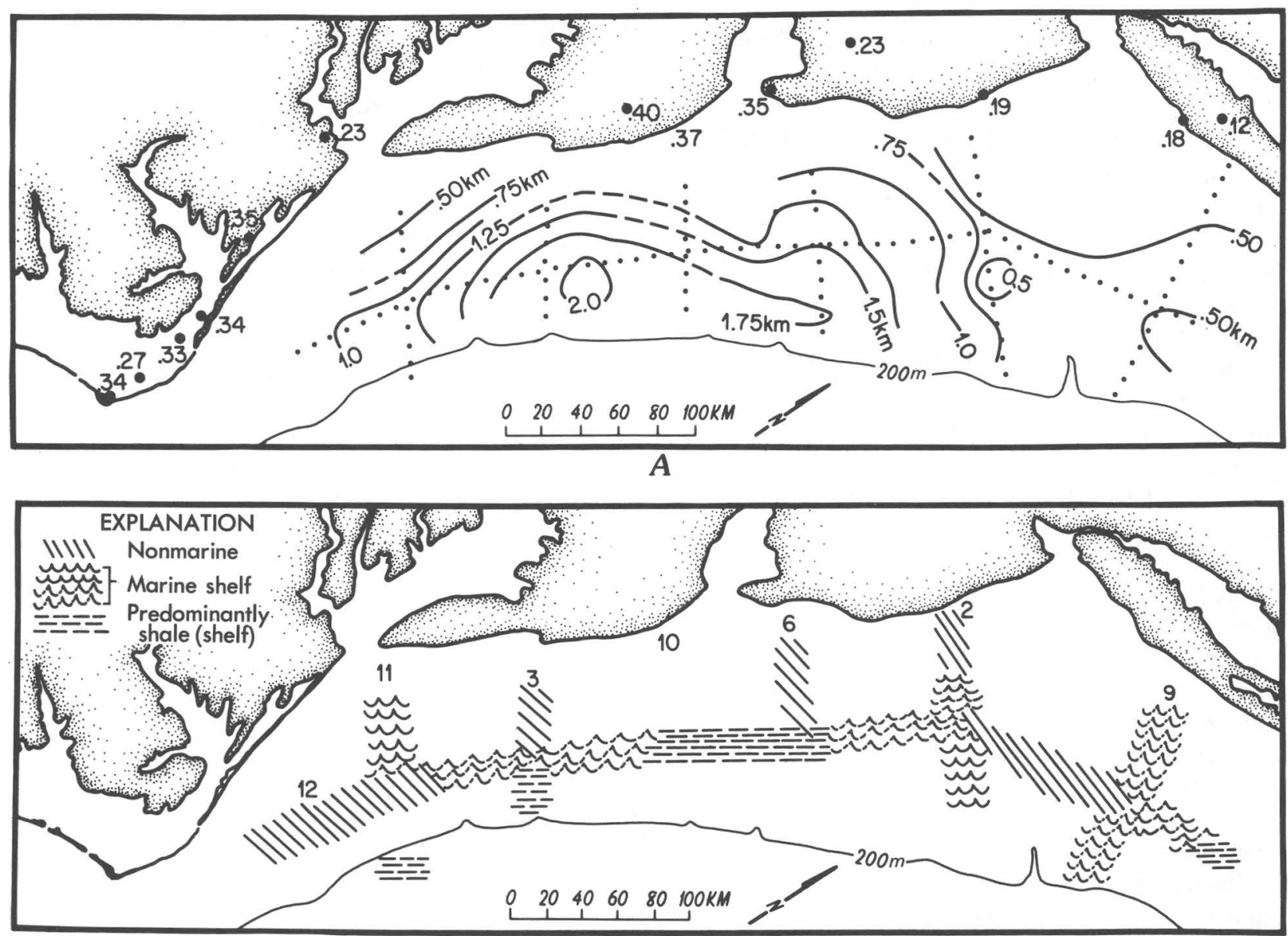

B

FigURE 47. - Maps showing characteristics of unit D (see fig. 39) in the Baltimore Canyon Trough area. $A$, Thickness, in kilometers. $B$, Depositional environment. $C$, Averaged interval velocity, in kilometers per second. In $A$, the dots indicate control for thickness. Contours are dashed where seismic data were difficult to interpret. In $B$, numbers represent USGS seismic lines shown in figure 1 . In $C$, velocity values are the arithmetic mean of values at 3-5 shotpoints between black lines. Asterisked $\left({ }^{*}\right)$ interval velocities were calculated for areas where the boundaries of the unit were difficult to pick; these values, therefore, are only approximate. 
reflectors are beveled at a low angle by the overlying onlapping sequence.

Unit D thickens to a maximum of $2 \mathrm{~km}$ off Maryland though it is also more than $1.5 \mathrm{~km}$ thick off southern New Jersey. It thins to less than 0.5 $\mathrm{km}$ under the Atlantic Coastal Plain and Inner Continental Shelf, where thickness change is seen mainly as a low-angle divergence of reflectors on tcross-shelf profiles.

Continuity of reflectors in unit D is low to moderate as is the seismic amplitude. The seismic patterns are interpreted to indicate a marine-shelf environment for the outer part of the present shelf and a nonmarine environment toward the present coast. Apparently, conditions over much of the marine shelf were uniform enough so that the type of sediment deposited did not change abruptly; thus, the reflectors have low to modest continuity and amplitude. The COST No. B-2 well drilled a sequence of calcareous, fine- to medium-grained sandstone, pyritic red and gray shale, limestone, and coal, most of which is thought to have been deposited in a shallow marine environment (Scholle, 1977a, fig. 4; Poag, 1977, p. 36). Inshore, along the present coast line (fig. 40), unit D was deposited in a nonmarine environment (Poag, this volume), except in North Carolina where marginal marine conditions existed. Interval velocities (fig. 47 ) in unit $D$ average about $2.3-4.0 \mathrm{~km} / \mathrm{s}$ and tend to increase toward the thicker, more marine part of the unit. Such velocity values are found in fairly well-indurated sandstones and shales (Gardner and others, 1974) having bulk densities that range from 2.2 to $2.4 \mathrm{gm} / \mathrm{cm}^{3}$. Interval velocities from the COST No. B-2 well for this unit range from 3.5 to $3.9 \mathrm{~km} / \mathrm{s}$ and are slightly higher than were calculated for that part of line 2 closest to the well.

Unit $\mathrm{E}$ represents dominantly marine-shelf deposits (fig. 48) inferred to be Late Cretaceous and possibly early Paleocene in age. It forms a broad sheetlike deposit that extends eastward onto the Atlantic Coastal Plain (fig. 40) where marineshelf and marginal-marine conditions existed (Poag, this volume). The lower boundary of unit $\mathrm{E}$ is marked by onlap of basal reflectors in the southern part of the trough (line 11) and on the faulted Long Island platform (line 9), but mostly, the unit is in apparent conformity with the underlying one. The upper contact can be marked by downlap of reflectors from the overlying unit as seen on several of the cross-shelf lines, where a delta was probably built across part of the shelf during the Tertiary. On most profiles, the upper boundary of unit E shows conformity with reflectors above and below it.

Unit $\mathrm{E}$ thickens in an offshore direction (fig. 48) in an irregular fashion. Unit $\mathrm{E}$ is more than $1 \mathrm{~km}$ thick in the southern part of the trough and is $0.5-0.75 \mathrm{~km}$ thick in the northern part. Along the coast, the thickness is $0.33 \mathrm{~km}$ or less, and Unit $\mathrm{E}$ thickens to more than $0.6 \mathrm{~km}$ in the south.

A marine-shelf environment is interpreted for the deposition of unit $\mathrm{E}$ on the basis of the moderate to high continuity of reflectors and the low to high seismic amplitudes. The unit probably accumulated as a broad sheet except at the seaward part of line 11, where a sigmoidal arrangement of reflectors probably indicates ancestral shelf-edge deposits. The COST No. B-2 well penetrated medium-grained sandstone, shale, lignite, and limestone (Scholle, 1977a, fig. 4) that was deposited mainly under marine conditions (Poag, 1977, p. 36; Valentine, 1977, p. 40), though a 275-m interval of the section was unfossiliferous and was presumed to be nonmarine. Coastal wells (fig. 40) also indicated a marginal-marine or a marine-shelf environment for the equivalent of the section under the Atlantic Coastal Plain (Poag, this volume).

Average interval velocites in unit $\mathrm{E}$ range from 2.2 to $3.3 \mathrm{~km} / \mathrm{s}$ - values that are in the range of those for sandstone and shale (Gardner and others, 1974). The rock types penetrated in the COST No. B-2 well have interval velocities that range from 2.6 to $3.0 \mathrm{~km} / \mathrm{s}$ (Smith and others, 1976). These are similar to, though slightly less than, the values on line $2(3.2-3.05 \mathrm{~km} / \mathrm{s})$.

The next higher unit, $\mathrm{F}$ (inferred age: Paleocene to middle Oligocene), is also probably of marine origin, has a range of interval velocities from 1.9 to $2.6 \mathrm{~km} / \mathrm{s}$, and attains a maximum thickness of 0.5 $\mathrm{km}$ under the middle part of the shelf off Delaware (fig. 49). Reflectors within the unit are mainly parallel (table 1) except off Delaware and southern New Jersey, where a sigmoidal and obliqueprogradational arrangement of the reflectors is present. The contact at the base of unit $F$ is easily distinguished in many areas (fig. 50) because of downlap by reflectors in the lower part of the unit, but some onlap also is present where the unit thins adjacent to the coast. The contact at the top of unit $F$ is also easily discerned (fig. 50) because of downlap onto the unit by the overlying Unit $\mathrm{G}$-particularly at the seaward ends of the crossshelf lines. 


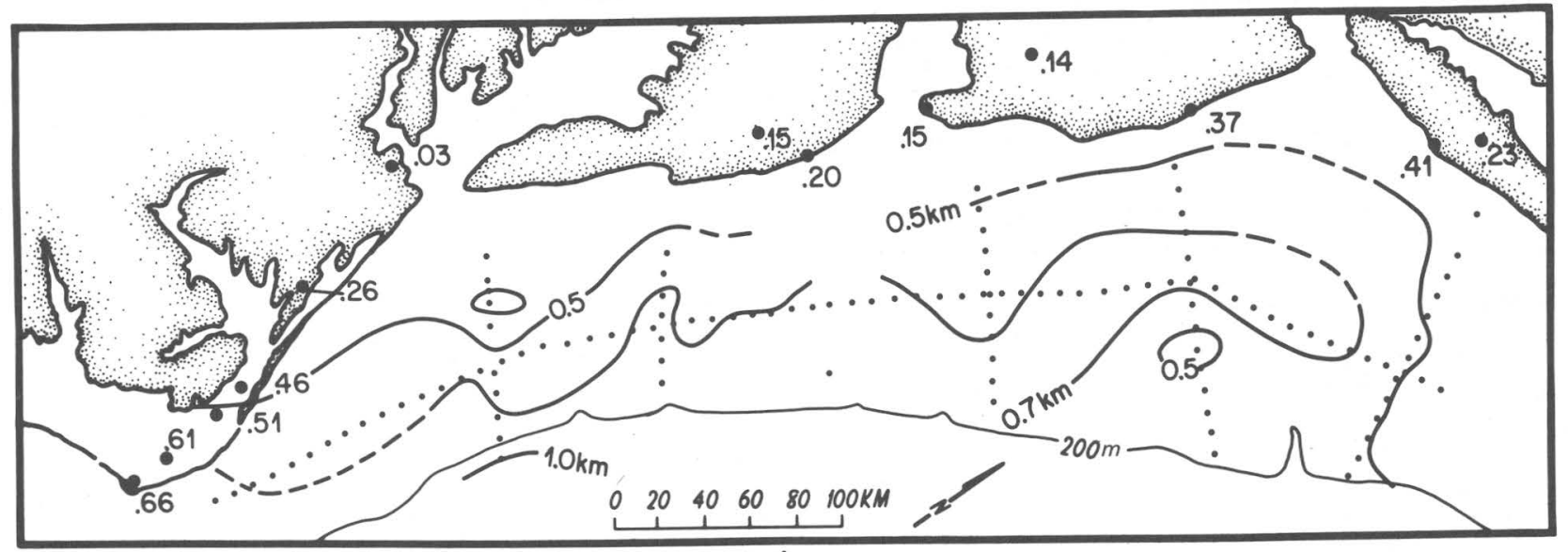

A

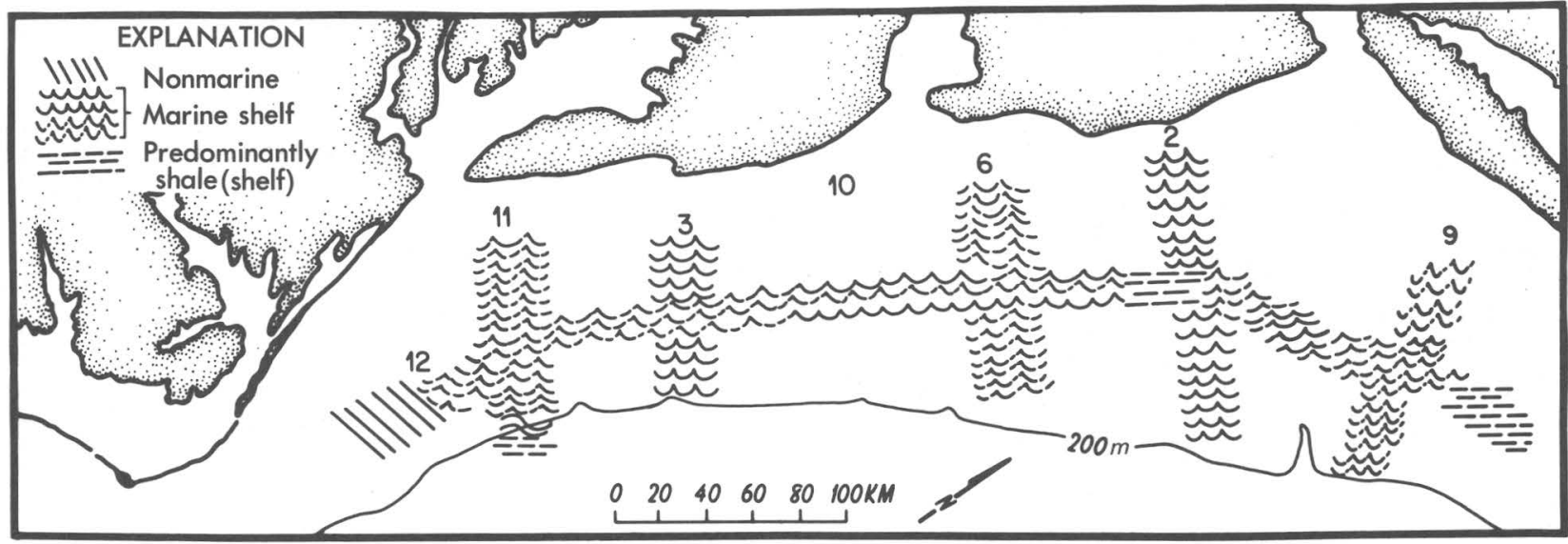

B

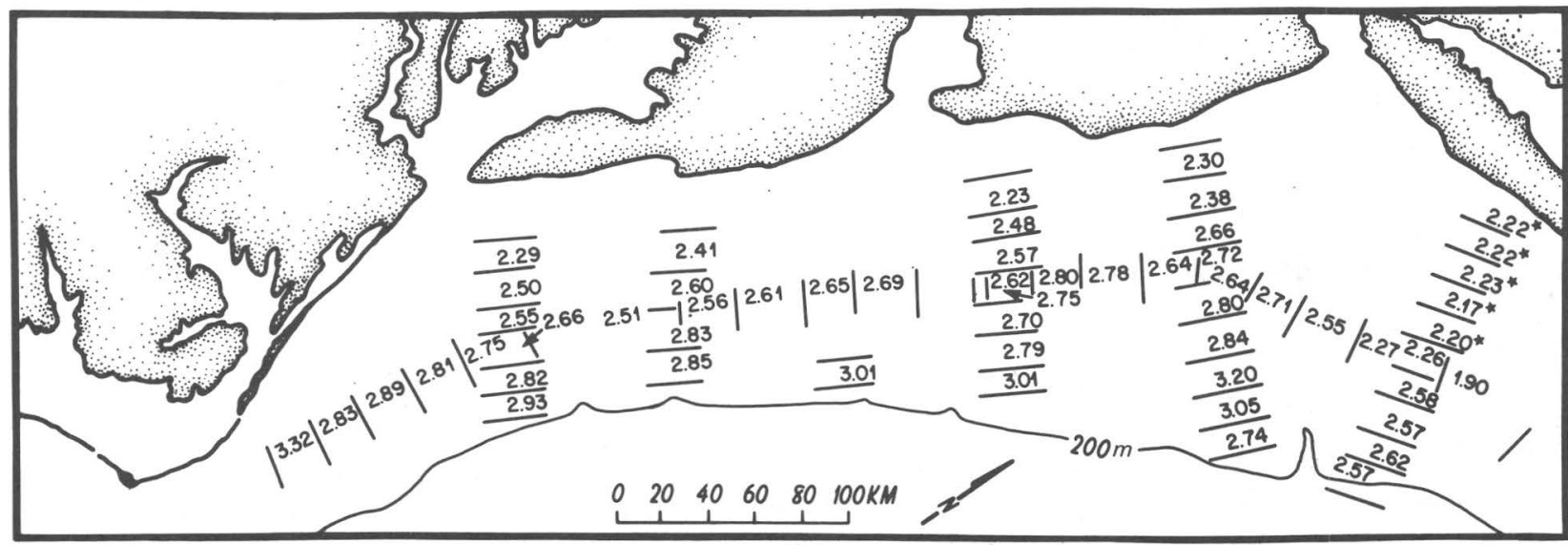

FIGURE 48. - Maps showing characteristics of unit E (see fig. 39) in the Baltimore Canyon Trough area. $A$, Thickness, in kilometers. $B$, Depositional environment. $C$-Averaged interval velocity, in kilometers per second. In $A$, the dots indicate control for thickness. Contours are dashed where seismic data were difficult to interpret. In $B$, numbers represent USGS seismic lines shown in figure 1 . In $C$, velocity values are the arithmetic mean of values at $3-5$ shotpoints between black lines. Asterisked $\left({ }^{*}\right)$ interval velocities were calculated for areas where the boundaries of the unit were difficult to pick; these values, therefore, are only approximate. 


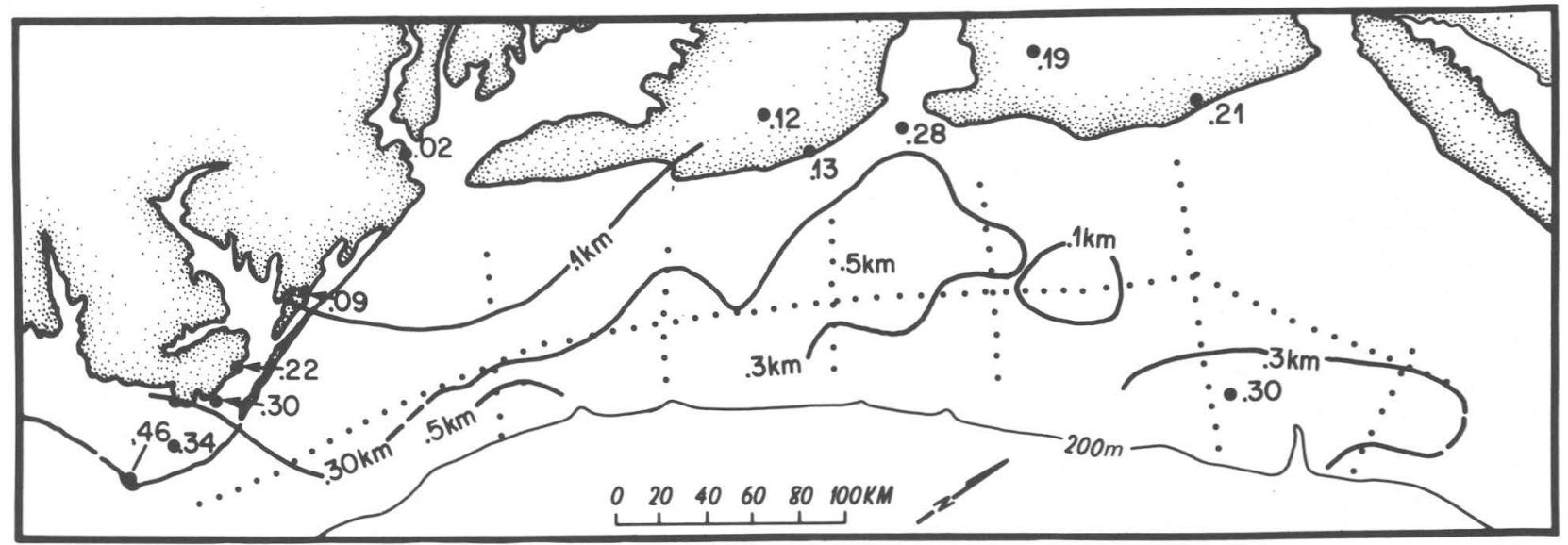

A

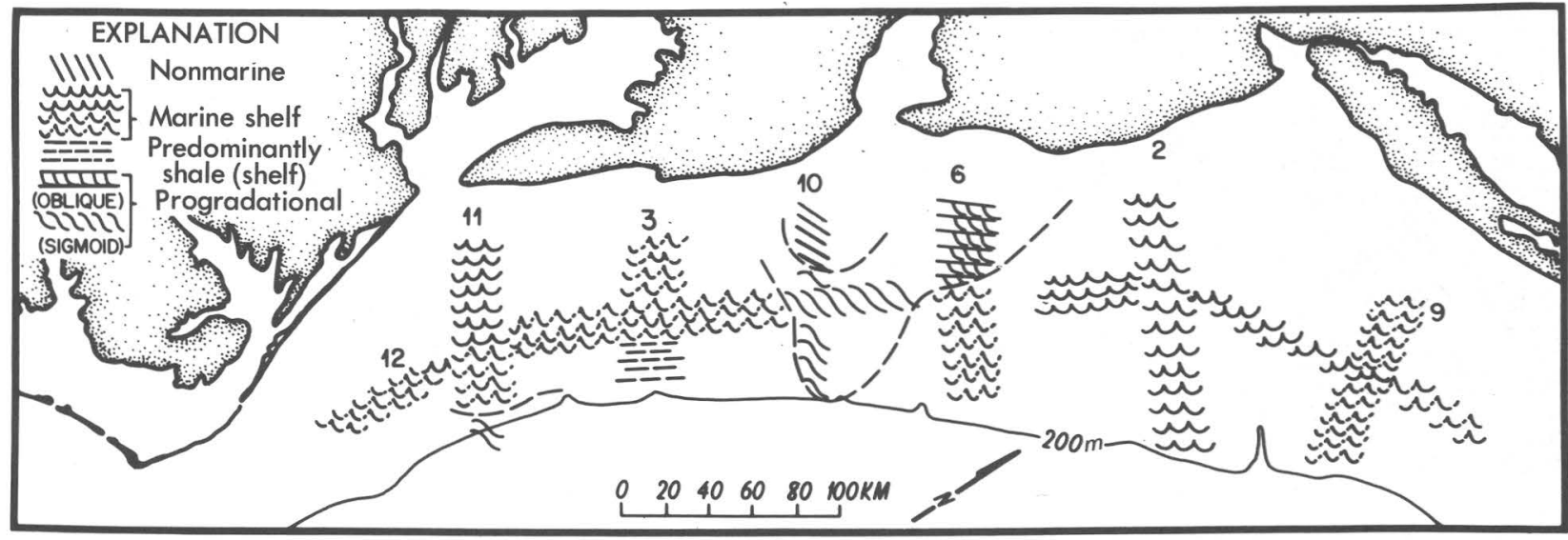

B

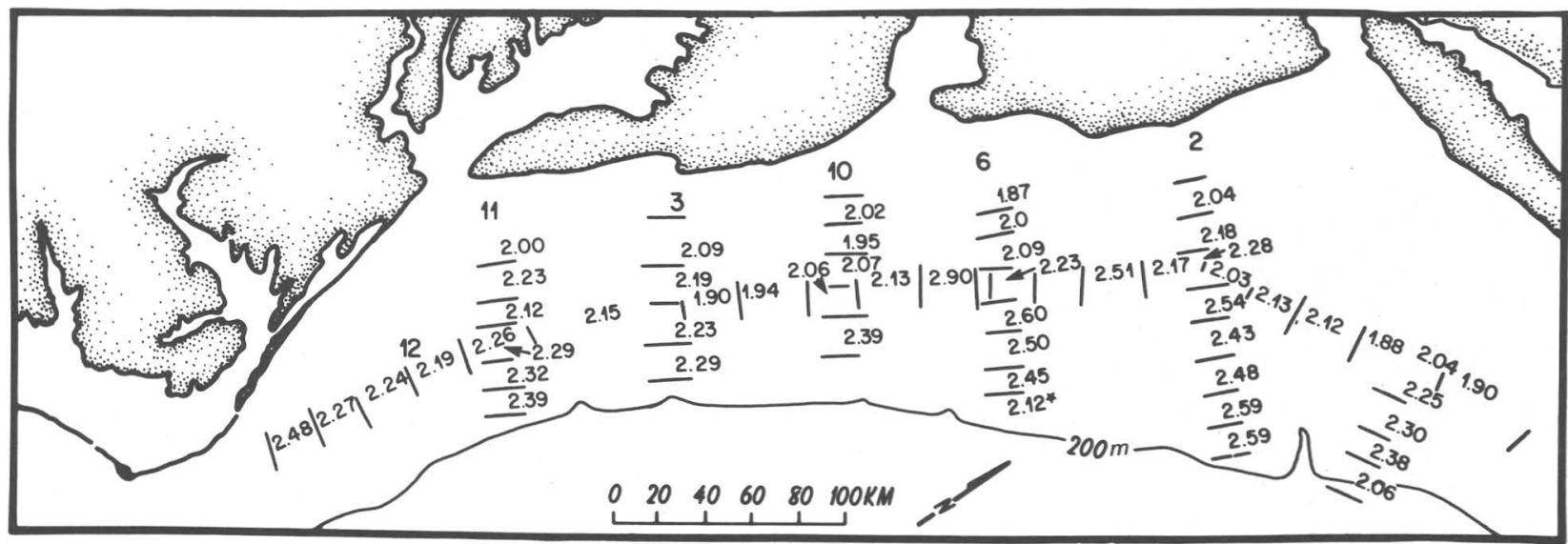

C

Figure 49.-Maps showing characteristics of unit F (see fig. 39) in the Baltimore Canyon Trough area. $A$, Thickness, in kilometers. $B$, Depositional environment. $C$, Averaged interval velocity, in kilometers per second. In $A$, the dots indicate control for thickness. Contours are dashed where seismic data were difficult to interpret. Area between dashed lines in $B$, is where deltas probably prograded seaward during deposition of unit F. In $B$, numbers represent USGS seismic lines shown in figure 1. In $C$, velocity values are the arithmetic mean of values at 3-5 shotpoints between black lines. Asterisked (*) interval velocity was calculated for an area where the boundaries of the unit were difficult to pick; this value, therefore, is only approximate. 


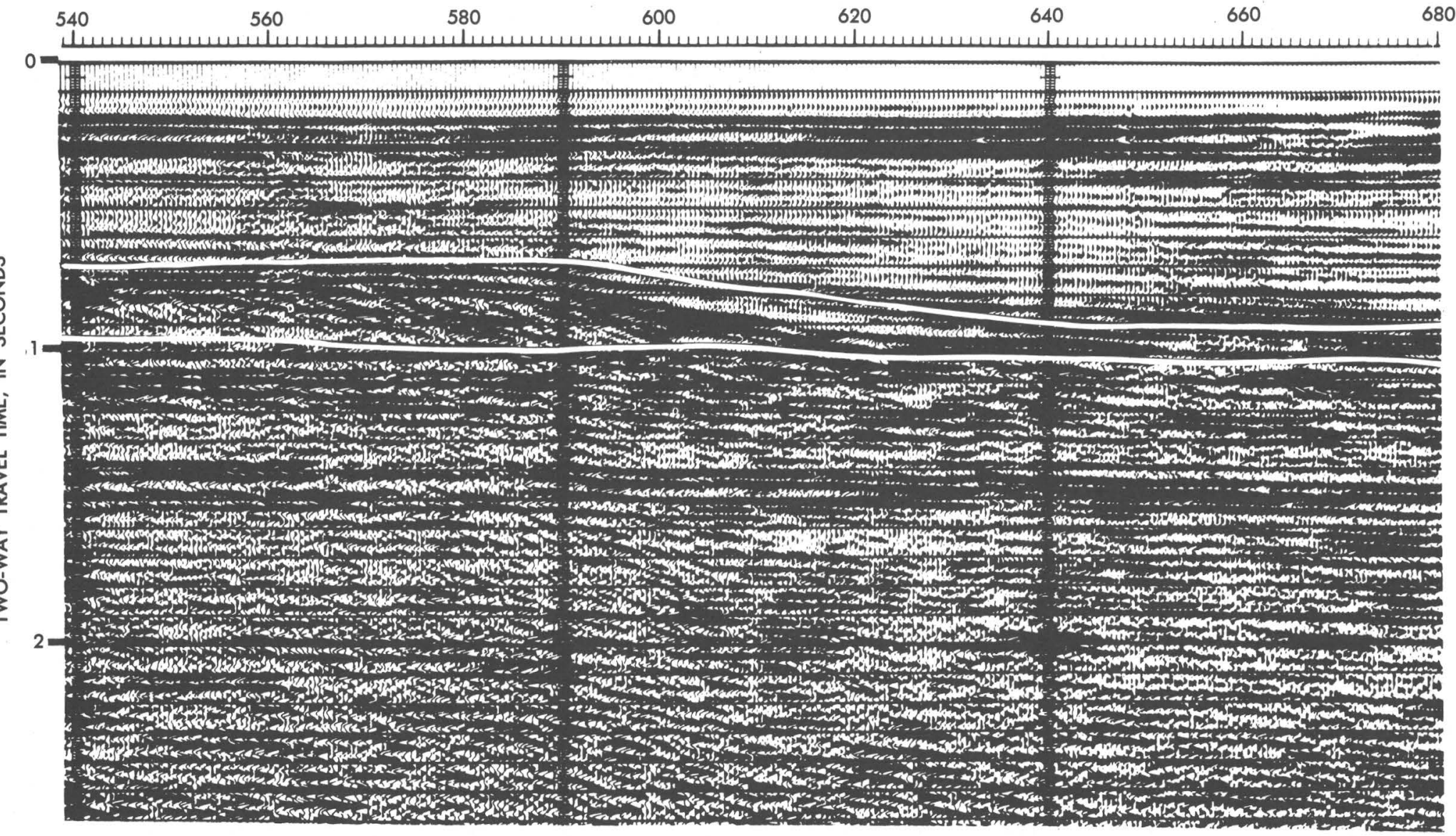

FIGURE 50.-An enlargement of a part of figure 38 (line 6) to show the delta built during accumulation of unit $\mathrm{F}$ as an oblique progradation of the ancestral shelf in a seaward direction (east). Top and bottom of unit F are shown by solid lines. Location of section for figure 38 is shown in figure 1. 
The reflectors in unit $\mathrm{F}$ show low to high continuity and moderate to high amplitudes. The pattern of the reflectors from most of the shelf suggests deposition on a marine shelf where presumably clastic sediments accumulated under varying energy conditions (well-bedded sequence near line 2; less well stratified sequence on lines 3 and 11). Off Delaware, the arrangement of the reflectors in a sigmoid or oblique-progradational pattern and the change to a possible nonmarine sequence at the inshore end of line 10 suggest that a delta may have existed off that area during the early Tertiary. Coastal stratigraphy for this interval shows no evidence for the onland continuation of this delta. In Delaware, the Piney Point Formation of Eocene age (Talley, 1975) is a marine glauconitic sand, unconformably overlain by the Chesapeake Group of Miocene age. Possibly the delta formed offshore during the Oligocene when part of the Coastal Plain was being eroded. As can be seen from the isopach map (fig. 49), unit $\mathrm{F}$ is thickest near the delta (greater than $0.5 \mathrm{~km}$ ) and thins away from there. Elsewhere on the shelf, unit $F$ is inferred to be $0.1-.4 \mathrm{~km}$ thick. Near the present shelf edge on line 11, Unit $F$ exceeds $0.5 \mathrm{~km}$ in thickness and is thought to have formed as an ancient shelfedge deposit because of the sigmoidal arrangement of reflectors at a position seaward of a presumed marine shelf (fig. 49).

Averaged interval velocities in unit $\mathrm{F}$ range from 1.9 to $2.6 \mathrm{~km} / \mathrm{s}$, but are mainly 2.2 to $2.4 \mathrm{~km} / \mathrm{s}$. In this unit also, higher values are toward the outer edge of the shelf. The lithologies under the shelf are known in two places. Under the New Jersey shelf, $0.3 \mathrm{~km}$ of shale, claystone, and argillaceous limestone was penetrated in the COST No. B-2 well, and $20 \mathrm{~m}$ of fine-grained silty glauconitic sand and gray-green micaceous shelly clay (middle to lower(?) Eocene) was penetrated in AMCOR 6011 (11 km east of Barnegat Inlet, N.J.). Rocks in this interval have also been dredged and drilled on the Continental Slope (Weed and others, 1974), where they formed in deep water, not unlike their present environment (Poag, 1978).

The overlying unit $(\mathrm{G})$ is inferred to be marine, to be as much as $1 \mathrm{~km}$ thick, and to be late Oligocene to early Miocene in age (fig. 51). The lower boundary of unit $\mathrm{G}$ onlaps the truncated edge of the underlying unit toward the inner part of the shelf. Under the middle and outer parts of the shelf, unit $\mathrm{G}$ downlaps the older unit, building a broad flat sedimentary apron across the shelf. An upper boundary can be distinguished on most lines; but on part of lines 2,6 , and 10 , it is not clear enough to be delineated (dashed area surrounding line in fig. 51). Where the upper boundary can be distinguished, lower reflectors of the unit above unconformably overlie the truncated reflectors in the top of unit G, or the boundary is marked by apparent channeling of unit G. Most sections show that a parallel arrangement of reflectors though a sigmoid or complex oblique arrangement is present on the outer parts of lines 2,3 , and 11 .

The acoustic facies of unit G (fig. 51) are thought to represent mainly those of a marine shelf, prograded at the shelf edge in the south and broadly prograded south of Long Island. The similarity of the area of broad progradation to a deltaic lobe was first noticed by Garrison (1970), who thought the lobe was Oligocene in age. At the COST No. B-2 well location (Scholle, 1977a, fig. 4), the sediments that are now shale, coarse-grained sandstone, and mudstone are thought to have accumulated in a shelf and deltaic environment (Poag, this volume). Unit $\mathrm{G}$ was drilled in AMCOR holes 6007B, 6010, and 6011 (Hathaway and others, 1976) where similar deltaic and marginalmarine environments are inferred (Poag, 1978; this volume) to have existed:

Unit G (fig. 51) is generally less than $0.5 \mathrm{~km}$ thick under most of the shelf, except for the northern seaward part of the trough, where it is as much as $1 \mathrm{~km}$ thick. The increase is in part artificial, because on lines 2,6 , and 10 , the youngest unit $(\mathrm{H})$ is not delineated; hence, its thickness is added in with that of unit G. However, on line 12, the youngest unit is not included in the thickness values, and the discrepancy at intersections of line 12 with lines 2,6 , and 10 is only between 0.1 and $0.2 \mathrm{~km}$. Therefore, the thicker accumulation in the northern part of the trough is probably real, though not as much as shown in figure 51 .

Average interval velocities in unit $\mathrm{G}$ are in the range of 1.6 to $2.5 \mathrm{~km} / \mathrm{s}$, well down in the range of velocities for poorly indurated shale (Woollard, 1962, p. III-42). Sediments having this range of velocity have densities ranging from 1.8 to 2.2 $\mathrm{gm} / \mathrm{cm}^{3}$ (Gardner and others, 1974); as shown by Woollard (1962, p. III-6), the same densities are found for equivalent age units and formations of Cretaceous age on the Atlantic Coastal Plain of New Jersey.

Unit $\mathrm{H}$ (table 1) probably represents a thin sheet of coarse- to fine-grained clastic sediment and is inferred to be a marine-shelf deposit of late Miocene and younger age. On lines 2,6 , and 10 , it is not 

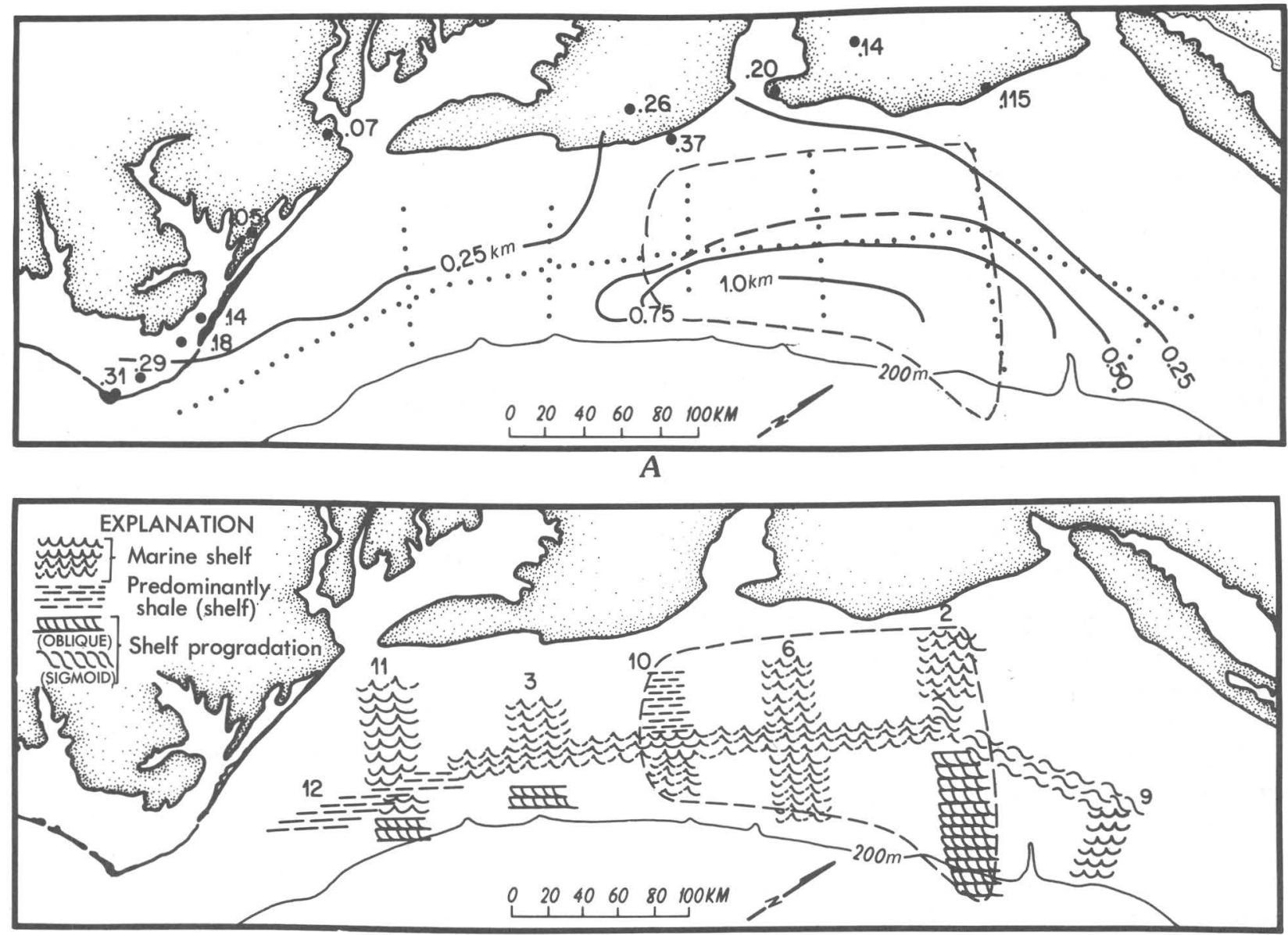

B

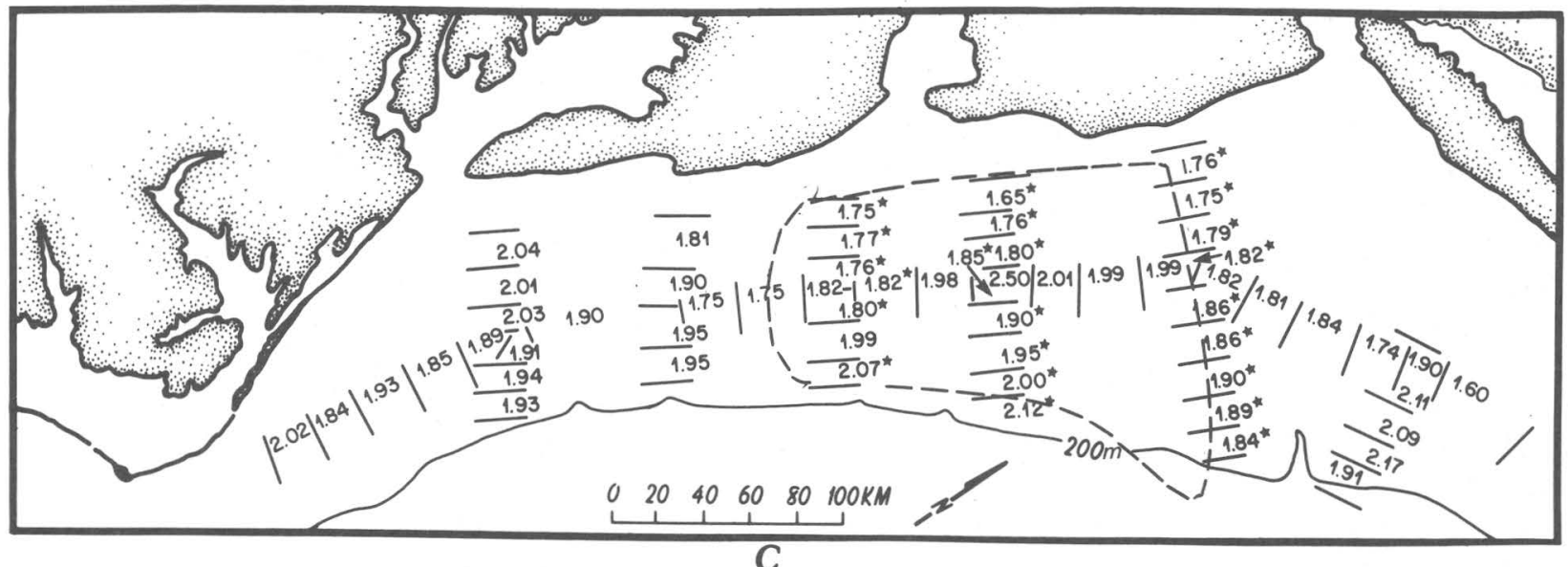

FIGURE 51.-Maps showing characteristics of unit G (see fig. 39) in the Baltimore Canyon Trough area. $A$, Thickness, in kilometers. $B$, Depositional environment. $C$, Averaged interval velocity, in kilometers per second. In $A$, the dots indicate control for thickness. Contours are dashed where seismic data were difficult to interpret. In $B$, numbers represent USGS seismic lines shown in figure 1 . In $C$, velocity values are the arithmetic mean of values at 3-5 shotpoints between black lines. In area enclosed by dashed line on all three maps, units $\mathrm{G}$ and $\mathrm{H}$ were not separated from each other on seismic lines 2, 6, and 10. Asterisked (*) interval velocities were calculated for areas where the boundaries of the unit were difficult to pick; these values, therefore, are only approximate. 
distinguished from the underlying unit (area enclosed by dashed line on fig. 52). On the other lines, the base of unit $\mathrm{H}$ is mainly distinguished by a conformable sequence of reflectors above and a truncated group of reflectors below. Reflectors in unit $\mathrm{H}$ downlap somewhat near the seaward shelf part of line 11. Reflectors in the unit are characterized by low to high continuity and by moderately high amplitude. They are mainly parallel or show a low angle of divergence.

Unit $\mathrm{H}$ is interpreted to represent a marine-shelf deposit (fig. 52). Progradations at the shelf edge are evident in the southern part of the trough (lines 3 and 11), and the unit has broadly prograded across the shelf on line 2 . The thickness of unit $\mathrm{H}$ is $0.1-0.3 \mathrm{~km}$, increasing toward the outer shelf (fig. $52)$. At the AMCOR holes (6007-6012, 6020, and 6021 ), the unit is mainly alternating sand, silty clay, and clay (Hathaway and others, 1976) and is approximately $0.12 \mathrm{~km}$ thick inshore (AMCOR holes 6008 and 6011 ) and more than $0.3 \mathrm{~km}$ thick at holes drilled on the upper slope (AMCOR holes 6012 and 6021). AMCOR holes 6009 and 6010, near the outer part of the shelf, gave values of 0.185 and $0.275 \mathrm{~km}$. Thickness figures are approximations because the holes did not detect a conspicuous unconformity in beds of late Miocene age. Hence, I measured to a silty clay bed in the upper part of the Miocene section to obtain the thickness figures, or I used the entire section if sediments as old as late Miocene were not drilled.

Poag (1978) postulated a marginal marine to lagoonal and fluvial environment for the Pleistocene section of the inner-shelf holes; the Pleistocene section offshore was formed in an inner marine-shelf and lagoonal environment. The Pliocene section shows similar types of environments but is thinner. Averaged interval velocities for unit $\mathrm{H}$ are between 1.55 and 1.88 $\mathrm{km} / \mathrm{s}$. The range is similar to what Wollard (1962, p. III-42) has compiled for terrigenous mud and saturated sand and silt. Hence, poorly consolidated sand, silty clay, and clay fit well with velocity values observed.

\section{DISCUSSION}

Once the acoustic units are described, the thickness and depositional environment can be interpreted over the wider interval of a system to see broad trends that were present as the trough sub- sided. Trends in the Baltimore Canyon Trough area can be compared with those in the more intensively studied Scotian margin.

If the thickness values of the lowest two units (A and B) are combined (fig. 53), an isopach map of presumed Jurassic and Triassic Systems is obtained. A part of the Upper Jurassic sequence is probably put in with the Cretaceous System, because the unconformity between units $\mathrm{B}$ and $\mathrm{C}$ does not appear to straddle this time boundary. Even with this discrepancy, units A and B together are more than $8 \mathrm{~km}$ thick in a depocenter areally restricted to the northern part of the trough. Toward Long Island, the sequence thins in an irregular manner because it fills grabens. Thinning toward the New Jersey coastline is rapid but it is more gradual toward the southern part of the trough. The facies for the Jurassic and Triassic Systems (figs. 43 and 45 ) is thought to be mainly nonmarine sedimentary rocks bedded with evaporite deposits. Obviously, marine waters were able to extend into the trough although they had restricted circulation.

During the Middle and Late Jurassic, the marine environment appears to have become more open, and reefs and banks consequently could form along the seaward side of the trough, probably in a discontinuous manner. Sand flats occupied the central part of the trough, and these probably graded laterally into nonmarine red beds that accumulated in a bordering coastal plain.

During the Cretaceous (fig. 54), the trough was much broader, though the accumulation of sediment was much less. If the thicknesses of units $C$, $\mathrm{D}$, and $\mathrm{E}$ are totaled, then $4-5 \mathrm{~km}$ of sediment accumulated. Most of it accumulated toward the outer part of the shelf (between lines 3 and 9) and was deposited during the Late Jurassic and Early Cretaceous, to judge by data from the COST No. B-2 well. Gradually, the system thins to between 1 and $2 \mathrm{~km}$ near the coastline. The circular anomaly (Great Stone dome) on line 2 is, in many respects, similar to the Zuidwal structure in Holland-a buried volcanic complex also emplaced during the Early Cretaceous and approximately $10 \mathrm{~km}$ across. Lower Cretaceous sandstones compacted around the Zuidwal structure are estimated to contain natural-gas reserves of 42 million $\mathrm{m}^{3}$ (Cottençon and others, 1975).

The Cretaceous units (figs. 46, 47, and 48) show two main trends: a diminishing rate of sediment accumulation (already mentioned), and a change from an almost wholly nonmarine sequence of clastic sedimentary rocks to almost all marine- 


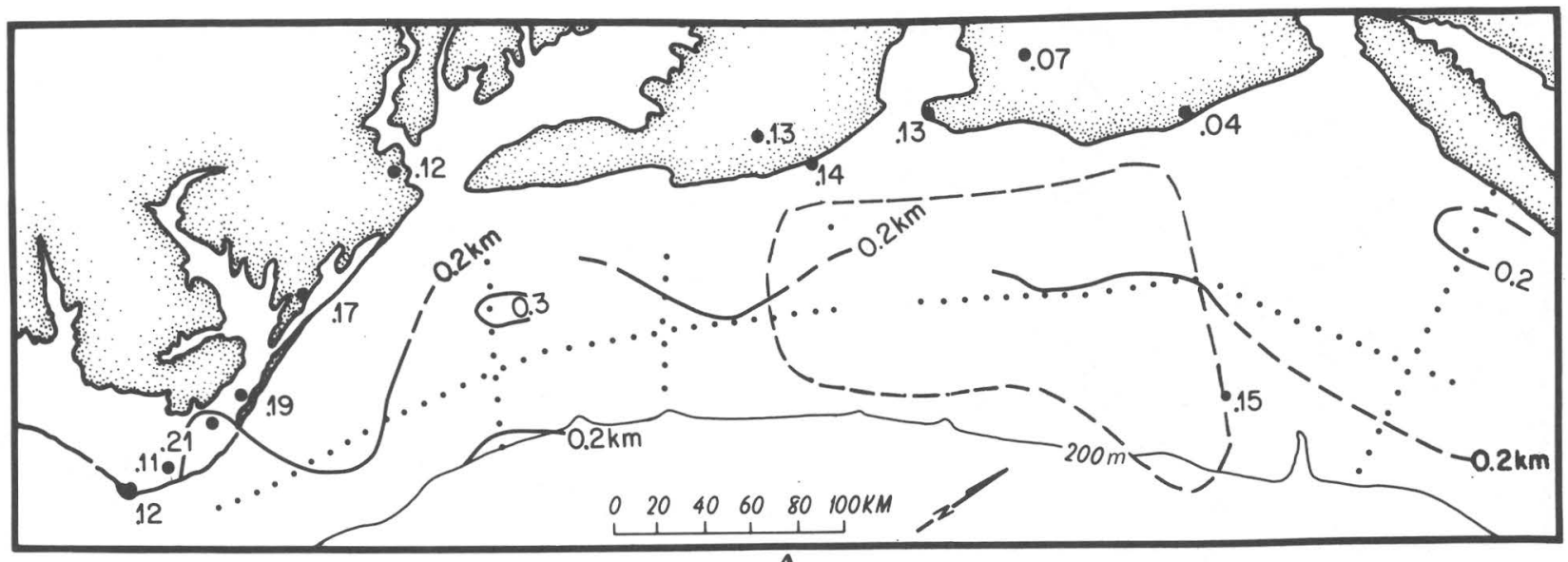

A
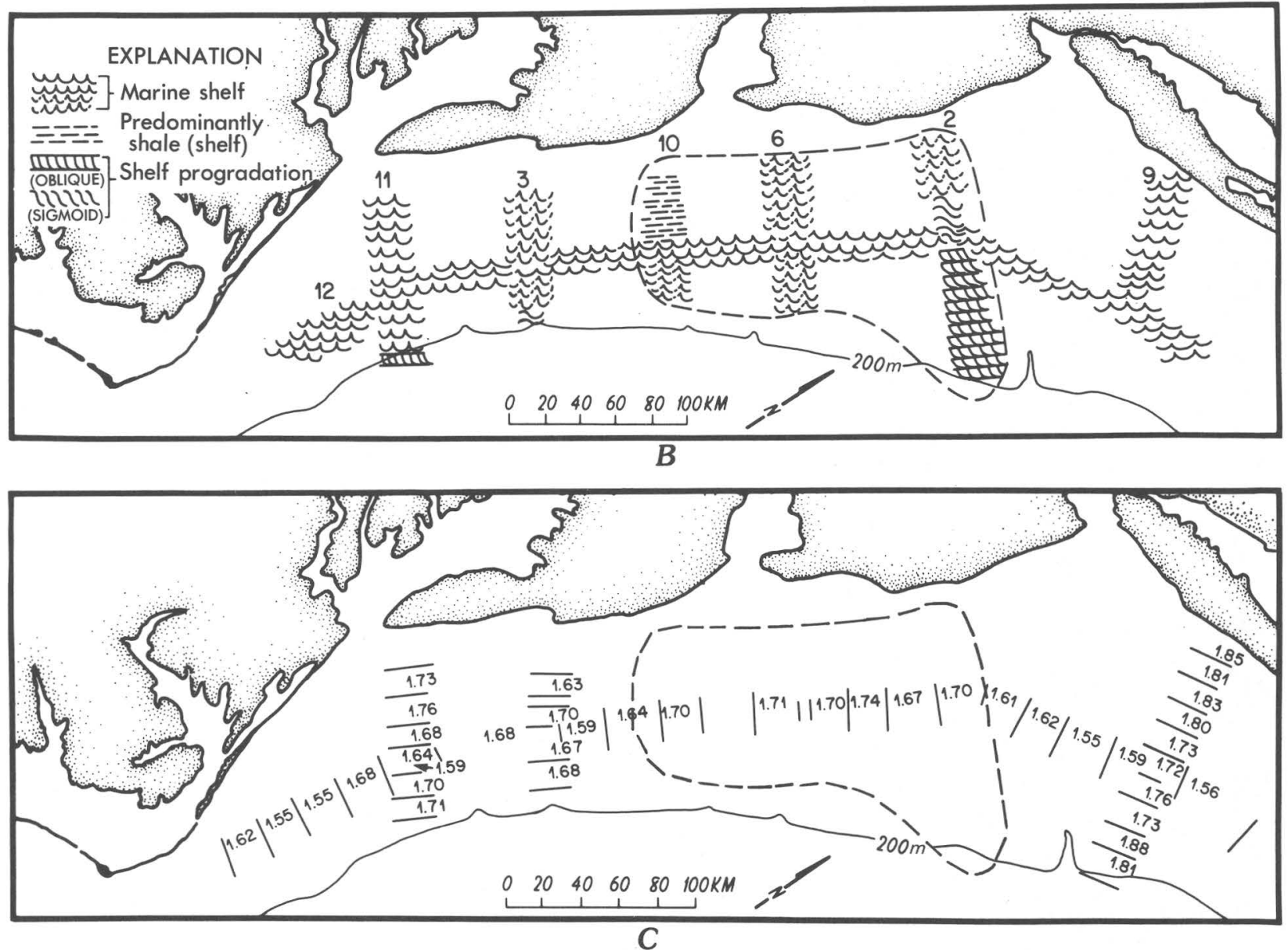

FIgURE 52. - Maps showing characteristics of unit $\mathrm{H}$ (see fig. 39) in the Baltimore Canyon Trough area. A, Thickness, in kilometers. $B$, Depositional environment. $C$, Averaged interval velocity, in kilometers per second. In $A$, the dots indicate control for thickness. Contours are dashed where seismic data were difficult to interpret. In $B$, numbers represent USGS seismic lines shown in figure 1 . In $C$, velocity values are the arithmetic mean of values at 3-5 shotpoints between the black lines. In area enclosed by dashed line on all three maps, units $\mathrm{G}$ and $\mathrm{H}$ were not separated from each other on seismic lines 2, 6, and 10; the interval velocities for both units along these lines are shown in figure 51. 


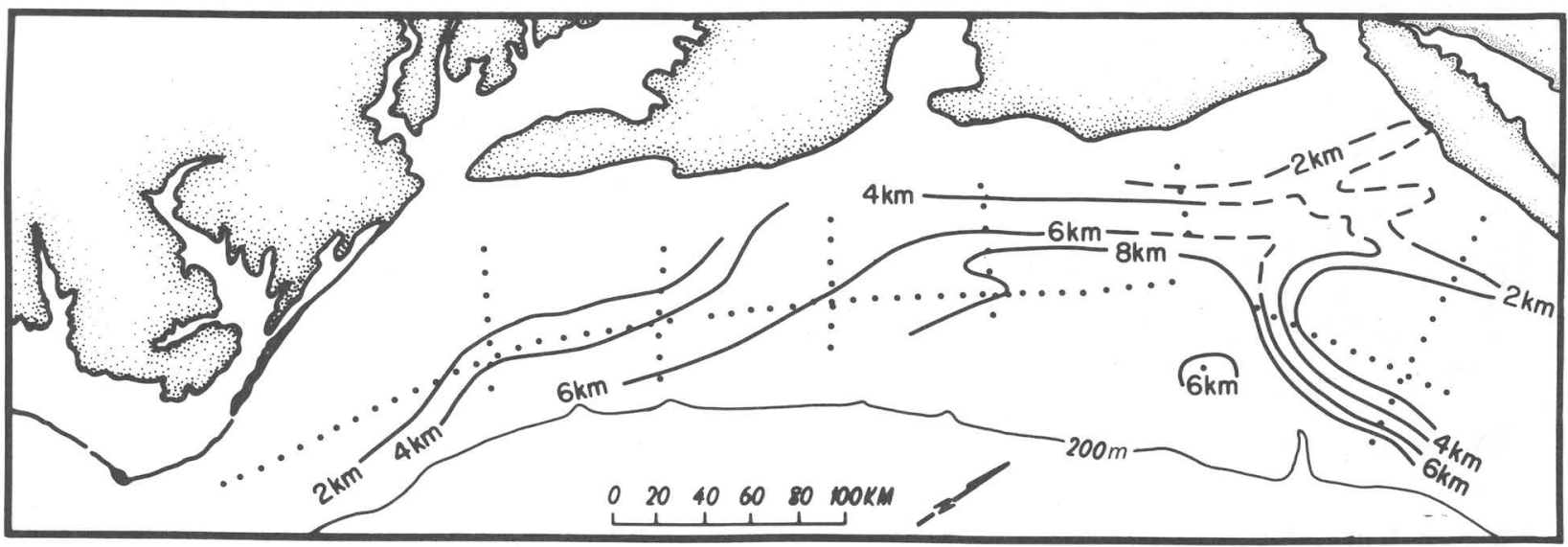

FiguRe 53. - Isopach map of probable Middle and Lower Jurassic and Triassic sedimentary rocks (units A and B combined; see fig. 39) in the Baltimore Canyon Trough area. Measurements are in kilometers. Control is shown by black dots. Dashed lines indicate areas in which seismic data were difficult to interpret.

shelf deposits. A broad regression during the Early Cretaceous built the shelf seaward over the reefs and the carbonate bank deposits. During the subsequent marine transgressions, the shelf became more of a marine site of deposition as worldwide sea level reached a maximum (Vail and others, 1977).

Similarly, Cenozoic deposits (fig. 55) are broadly spread over the trough and adjacent Coastal Plain in overlapping sheets of marine and nonmarine sediment. The maximum thickness is along the outer part of the Continental Shelf, though the sedimentary section is much thinner than the section that accumulated during the Cretaceous. Despite a broad trend toward gradual lowering of sea level during the Tertiary (Vail and others, 1977), subsidence in the Baltimore Canyon Trough was sufficient to maintain a marine environment over much of the area. The chiefly marine regime was punctuated by short intervals of sea-level drop, as evidenced by erosion of parts of the shelf, coastal swamps, and alluvial plains. Broad progradational sheets appear to have built up the shelf in the northern part of the trough during the Miocene and Pliocene in a regressional phase.

The overall shape of the Baltimore Canyon Trough (fig. 56) is a broad seaward-opening wedge. The deepest (oldest) part is restricted mainly to the outer and more northerly part of the trough. The rift-block foundation of the trough is best shown by the irregular pattern of isopach contours south of Long Island. Probably, other fault basins, as yet not clearly delineated, exist under the Baltimore Canyon Trough and Atlantic Coastal Plain. As shown on the profiles, the trough first formed mainly under the New Jersey shelf and gradually spread to the west and south as the area subsided after rifting (Falvey, 1974). The trough is asymmetrical in cross section, in that the slope of the basement is much less under the Coastal Plain than it is under the shelf, where steepening of the slope (hinge zone?) is pronounced particularly off New Jersey and New York.

The general pattern of margin formation deduced for the Baltimore Canyon Trough is very similar to that of the Scotian basin off eastern Canada (Given, 1977; Bally, 1976; Jansa and Wade, 1975a; King, 1975). As can be seen from the schematic cross section (Given, 1977, fig. 18g) of the Scotian basin (fig. 57), it has six main elements listed as follows:

1. A rifted continent basement containing Permian and Triassic(?) clastic sedimentary rocks in prerift basins.

2. A. rift-valley stage in the Late Triassic and Early Jurassic (deposition of red beds and evaporite deposits) following an interval of uplift and erosion (of elevated tilted edges of blocks).

3. A first major marine transgression (Middle Jurassic) resulting in deposition of limestone offshore and nonmarine clastic rock inshore.

4. Localization of carbonate banks over basement highs (Middle and Late Jurassic).

5. A major deltaic-regressive phase in the Early Cretaceous.

6. A Tertiary (Paleocene) regression, during which the broad configuration of the margin was established by progradation of the shelf in overlapping wedges of clastic sediment and 


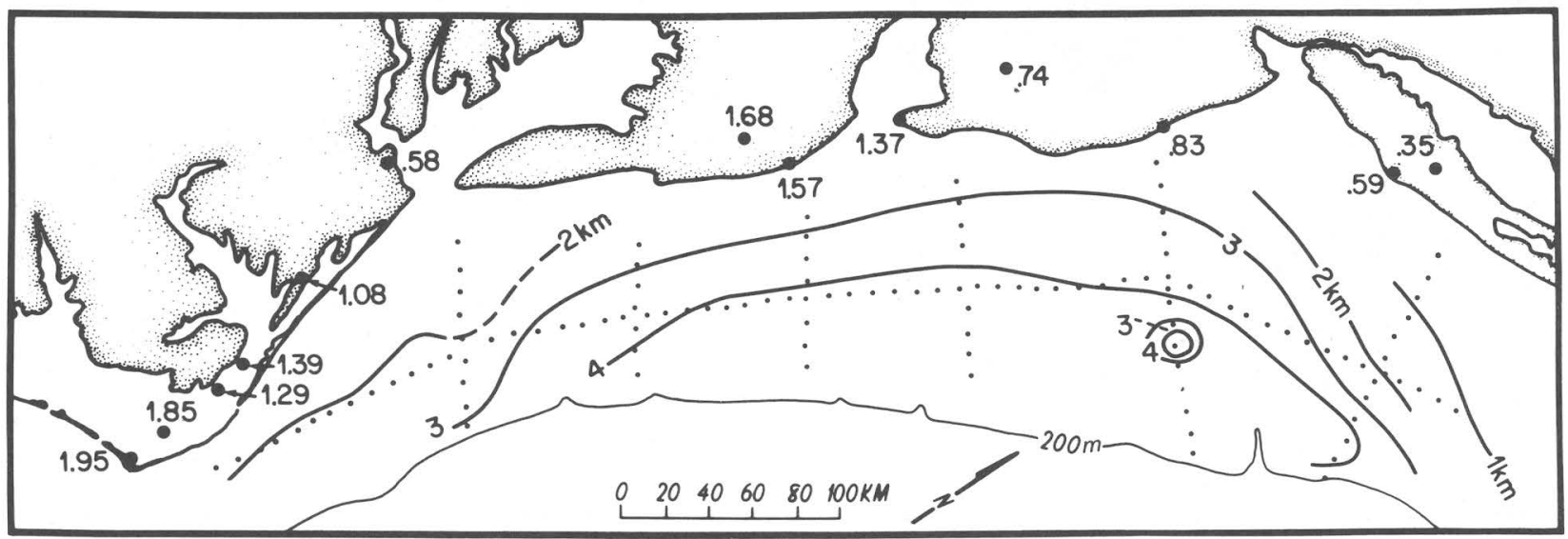

FigURE 54.- Isopach map of inferred Cretaceous and Upper Jurassic sedimentary rocks (units C, D, and E combined; see fig. 39) in the Baltimore Canyon Trough area. Measurements are in kilometers; control is shown by the black dots. Onshore data are provided from the wells shown in figure 40. Dashed lines indicate areas in which seismic data were difficult to interpret.

deposition of a lower slope-rise wedge of sediment.

A similar pattern exists in the Baltimore Canyon Trough. The regressive and transgressive cycles are probably more prevalent in the Cretaceous System of the Baltimore Canyon Trough than in the Scotian basin. Given (1977) distinguished Permian(?) prerift basins. I am not certain that these exist under the Balitmore Canyon Trough or how one would distinguish them from the syntectonic rift basins of Late Triassic and Early Jurassic age in the trough. Notwithstanding these minor differences, I think both margins fit the models of Falvey (1974) and Kinsman (1975) for Atlantictype margins having a rift phase followed by a broad subsidence phase. The rift phase involves block-faulting and accumulation of red beds and evaporite deposits (Van Houten, 1977), and the subsidence phase involves subsidence and accumulation of a massive sedimentary prism over deposits of the earlier formed phase.

\section{PETROLEUM GEOLOGY}

The discussion of the petroleum geology of the Baltimore Canyon Trough is divided into four sections entitled (1) General Comments, (2) COST No. B-2 Well, (3) Shelf, and (4) Slope. Analogies between the U.S. Atlantic margin and other offshore areas (producing and nonproducing) that are based on similarities in geology and proximity (taking in- to account continental reconstruction) are discussed in the first section. In the second section, analyses of cuttings, cores, and logs from the COST No. B-2 well (the only deep well on the shelf in the Baltimore Canyon Trough) provide information about lithology, depositional environments, organic carbon contents and types, thermal maturity, reservoir rock character, and presence or absence of seals. The petroleum geology of the shelf and slope are discussed separately in the last two sections on the basis of information from all the foregoing parts of this circular. The section pertaining to the shelf deals primarily with potential traps. More detailed information pertaining to the petroleum geology of the shelf can be found in Mattick and others (1974), Smith and others (1976), Scholle (1977b), and Schlee, Martin, and others (1977). The petroleum geology of the slope is discussed in more detail than that of the shelf because little direct information about the sediments or structures of the slope is available. Therefore, we discuss several hypotheses of sediment processes and possible structures derived chiefly from geophysical data and comparisons with other areas. We attempt to draw preliminary conclusions concerning source rock, reservoir rock, and potential traps on the slope.

\section{GENERAL COMMENTS}

By Robert E. Mattick and O. W. Girard, Jr.

Despite the great thicknesses of marine and continental sediments that have been identified along 


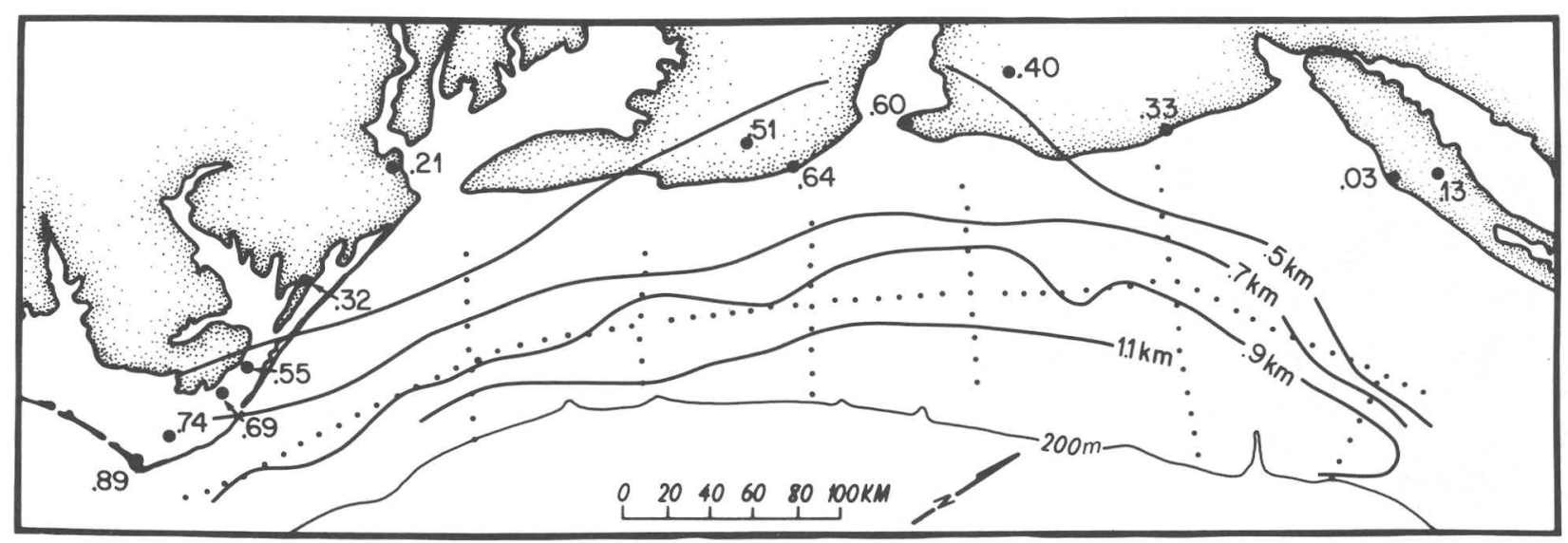

FIGURE 55. - Isopach map of inferred Cenozoic sedimentary rocks (units F, G, and H combined; see fig. 39) in the Baltimore Canyon Trough area. Measurements are in kilometers; control is shown by the black dots. Onshore control is from wells shown in figure 40.

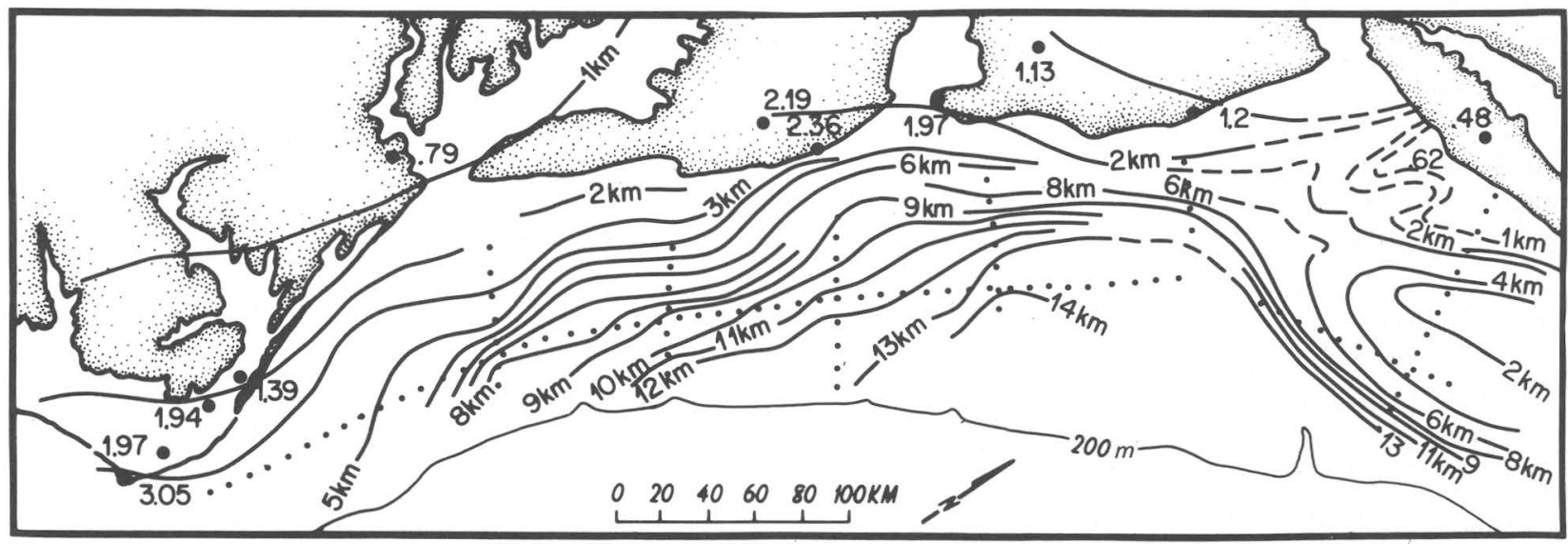

Figure 56.-Structure-contour map of the top of basement rocks in the Baltimore Canyon Trough area. Datum is sea level. Measurements are in kilometers; control is shown by the black dots. Onshore data are from wells shown in figure 40 . Dashed lines indicate areas in which seismic data were difficult to interpret.

the shelves and slopes of passive margins, large quantities of hydrocarbons have not been recovered from these areas. Examples are the Scotian Shelf and Grand Banks of offshore eastern Canada and the Northwest Africa shelves, which during Jurassic and Early Cretaceous time were close to the United States margin.

On the basis of an examination of samples from 63 wells from offshore eastern Canada, Bujak and others (1977) concluded that the Scotian Shelf and Grand Banks do not contain major hydrocarbon resources because of the nature of the organic material dispersed in the sediments and because the organic matter is immature. According to these authors, amorphous organic material, which can be transformed to hydrocarbons at relatively low temperatures, is common only in the Upper Cretaceous and Tertiary intervals. In these intervals, however, the Thermal Alteration Index (TAI) is too low (below 2-) for significant generation of hydrocarbons. In pre-Upper Cretaceous sedimentary rocks, the TAI commonly reaches 2 (sufficient to mature amorphous-type organic material), but the predominant organic types in these sediments are herbaceous and woody-both require a TAI greater than 2 to generate significant quantities of gas and liquid hydrocarbons. Apparently some organic material has matured on the Scotian Shelf at relatively shallow depths near salt diapirs where locally high geothermal gradients are present. Also, gas has been generated in the sediments offshore of Labrador, as evidenced by several gas discoveries there. 

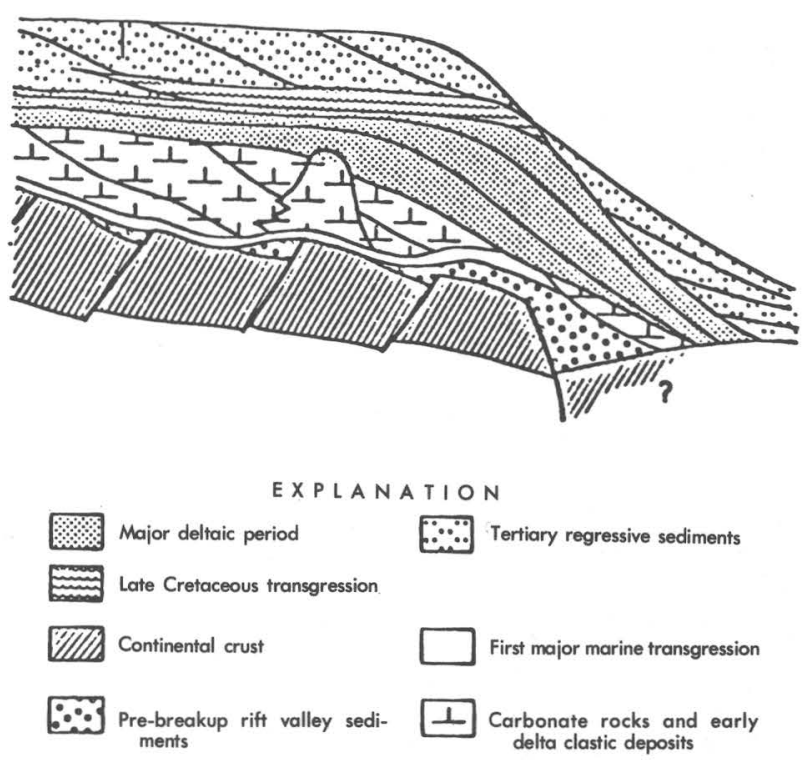

FIgURE 57.-Schematic section through the northern Scotian basin off the coast of Nova Scotia, Canada, showing main stratigraphic units (from Given, 1977, fig. 18g).

Rona (1970) compared the Eastern United States continental margin with the prerift opposing continental margin of Africa (Senegal basin) and noted that the margins appear similar with respect to late Precambrian, Paleozoic, and Mesozoic tectonic frameworks and early and middle Paleozoic, Mesozoic, and Cenozoic stratigraphic frameworks. To date, exploration on the northwest coast of Africa, both onshore and offshore, has been disappointing (Aymé, 1965; Alem, 1974; Lévy and others, 1975).

Other authors have discussed geologic observations that are pertinent to Atlantic-type margins and that could bear on the estimation of hydrocarbon resources in the Baltimore Canyon Trough area (for example, see Yarborough, 1977). These include the structural passivity of postrift sediments and possible insufficient maturation of organic material included in the postrift sediments.

Large anticlinal structures, commonly associated with the entrapment of significant quantities of oil and gas, are sparse on the shelves of Atlantic-type margins. Exceptions to this are areas of salt diapirism, such as the Gulf of Mexico and the Scotian Shelf. In the Baltimore Canyon Trough area, the results of geophysical surveys

and drilling (J. C. Hathaway, USGS, written commun., 1978) suggest that although some local salt flows exist, they are not widespread (some authors disagree with this interpretation; see Poag, this volume and Grow and Klitgord, this volume). However, at least one large mafic intrusion (the Great Stone dome, fig. 24) that deforms the postrift sedimentary strata has been mapped on the midshelf area. Seismic evidence (fig. 58) and the bidding activity associated with Lease Sale No. 40 (fig. 1) indicate that small anticlinal structures are common along the shelf edge and slope in the Baltimore Canyon Trough area. In addition, good possibilities exist that numerous structural traps related to rift or prerift tectonism are present along the shelf edge and slope. These possible traps include drape structures formed by the compaction of postrift sediments over older uplifted fault blocks. These basement blocks may have continued to move throughout Cretaceous time. If so, the chance of finding significant anticlinal and faultrelated hydrocarbon traps would be enhanced.

Sediments of Atlantic-type margins or divergent margins are considered to be thermally immature relative to sediments of convergent margins. Results from wells on the Scotian Shelf and the Baltimore Canyon COST No. B-2 well (Scholle, this volume) seem to bear this out. Analyses of disseminated organic matter from both areas suggest thermal immaturity with respect to generation and expulsion of economic amounts of liquid petroleum. However, thermal immaturity of the upper 4 or $5 \mathrm{~km}$ of sediment in itself should not discourage further exploration. According to Yarborough (1977), the immaturity of the Cenozoic and Cretaceous sedimentary rocks will permit deep and ultradeep exploration into the yet untested Lower Jurassic section, speculated to be about $6 \mathrm{~km}$ thick (fig. 3). Yarborough (1977) also suggested the possibility that prerift and early-rift lake deposits (Triassic age) could contain significant amounts of sedimentary rocks rich in organic material. In the Baltimore Canyon Trough area, however, these deeply buried deposits are probably sealed above by anhydrite deposits (fig. 3); this seal could have prevented the upward migration of expelled liquids and gases.

On the slope and along the outer edge of the shelf, maturation of organic material may not be a problem. Studies on the Scotian Shelf by Bujak and others (1977) indicate that the percentage of amorphous organic material, which can be converted to petroleum at relatively low temperatures, tends to 
$\stackrel{5}{1} \stackrel{1}{1} \stackrel{10}{1}$ KILOMETERS

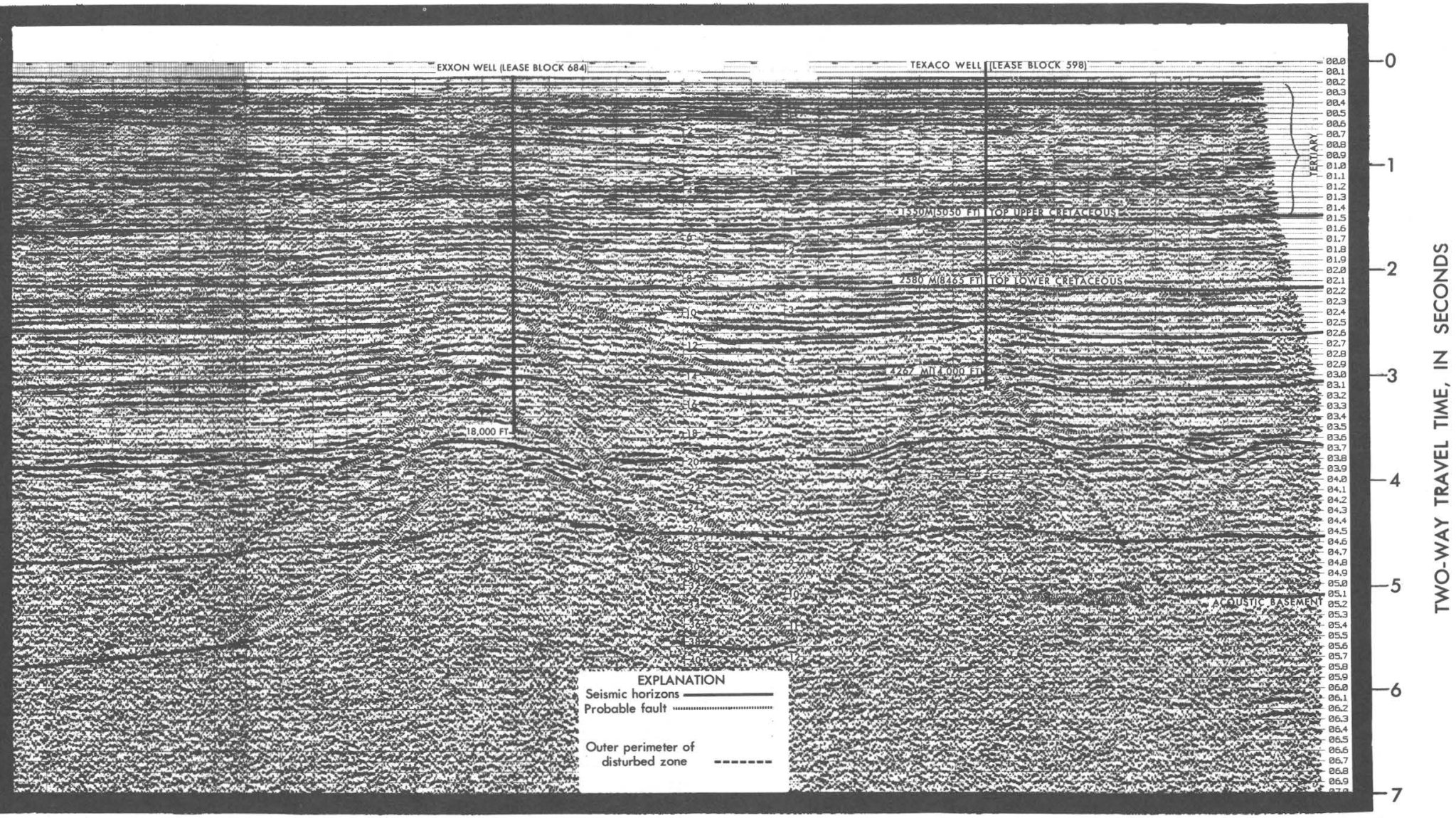

FiguRE 58. - Anticlinal structures along the shelf edge in the Baltimore Canyon Trough area as revealed by seismic profile 15. Location of seismic profile is shown in figure 1. The Texaco 598-1 well was the first discovery in the Baltimore Canyon Trough area. On initial tests, natural gas flowed from it at a rate of about $479,000 \mathrm{~m}^{3} /$ day from two intervals between depths of 3,950 and 4,300 m. The Exxon $684-1$ well was dry. 
increase in the direction of deep-water environments. Mattick and others (1977) suggested that petroleum could have been generated under the present lower slope and rise in basin facies rich in organic matter; the petroleum could have migrated to reservoirs in the upper slope or along the shelf edge.

Another attractive target would be the Mesozoic shelf margin, which is below the present-day Continental Slope. Of special interest to petroleum exploration are potentially porous carbonate rocks that may be associated with this paleoshelf edge (fig. 3). The carbonate reef trends of the Edwards Limestone of Texas and El Abra-Tamaulipas Formation of the Mexican Golden Lane (known petroleum provinces) are good examples for comparison with the paleoshelf margin in the Baltimore Canyon Trough area. In addition, the paleoshelf margin in the Baltimore Canyon Trough area might be compared with the so-called Reforma trend in western Tabasco, Mexico, which produces from lower Turonian through Oxfordian bank-edge carbonate facies. According to Meyerhoff and Morris (1977), entrapment of petroleum in the Reforma trend is controlled not only by local structure but also by a regional updip seal of shelf and back-reef deposits and a downdip deep-water facies, which also is a prolific source rock. Proved, probable, and potential reserves of the onshore and offshore Reforma trend have been estimated at 62 billion bbls (barrels) (Meyerhoff and Morris, 1977).

To date, 17 wildcat wells have been completed or nearly completed offshore in the Baltimore Canyon Trough. The only significant gas discovery was in the Texaco 598-1 well, from which natural gas flowed at a rate of about $479,000 \mathrm{~m}^{3}$ per day from two intervals between depths of about 3,950 and $4,300 \mathrm{~m}$ (Texaco, 1978). A seismic line across the Texaco discovery is shown in figure 58.

\section{COST NO. B-2 WELL}

By Peter A. Scholle

The COST No. B-2 well (fig. 59) was the first deep offshore test in the Baltimore Canyon Trough area. The analysis of cuttings, cores, and logs from this well yielded information about sediment thicknesses. depositional environments, organiccarbon contents and types, thermal maturity, character of reservoir rock, and presence or absence of seals.
The well penetrated $4,772 \mathrm{~m}(15,655 \mathrm{ft})$ of Cenozoic and Mesozoic rocks. Lithologic and paleoenvironmental studies, summarized in figure 59 , indicate that the upper $600 \mathrm{~m}(2,000 \mathrm{ft})$ of section contains very sandy shallow-marine to nonmarine deposits. Between 600 and 1,800 m (2,000 and $6,000 \mathrm{ft}$ ), a deeper water, finer grained section is present. Below $1,800 \mathrm{~m}(6,000 \mathrm{ft})$, the section consists of alternating sandstones and shales of shallow-marine to nonmarine origin. This deeper part of the section contains many coal and lignite seams.

The Cretaceous section consists chiefly of relatively thick sandstone units, some of which have significant reservoir potential. The reservoir quality of this sandstone, however, deteriorates consistently as depth increases. The relationship between depth and petrophysical characteristics determined from electric logs, as well as from cores, is shown in figure 60 . The porosity loss below $3,700 \mathrm{~m}(12,000 \mathrm{ft})$ is largely related to compaction effects and to progressive breakdown of feldspar accompanied by growth of authigenic clay and silica cement. Generation of calcite cement is also important in the porosity loss, especially in zones that contain marine fossils or limestone. As can be seen in figure 60 , these porosity losses, especially those caused by the formation of authigenic clay, have a drastic effect on permeability. Thus, below 3,700 $\mathrm{m}(12,000 \mathrm{ft})$, few sandstones have more than 1 millidarcy $(\mathrm{mD})$ permeability.

The abundance of shales throughout the section suggests that material to form hydrocarbon seals is not lacking in this area, although in some intervals, the shales may be too thin to form effective hydrocarbon seals.

Geochemical studies of the COST No. B-2 well have shown that the Baltimore Canyon Trough area has a relatively low geothermal gradient today and that it apparently has had a gradient as low or even lower throughout the Cretaceous to Holocene. A controversy exists concerning the maturity of the basal sedimentary rocks in the COST No. B-2 well. Data on the degree of thermal alteration of visible organic matter, pyrolyticdecomposition temperatures, carbon-preference index, and vitrinite reflectance are summarized in figure 61 . All the data summarized in figure 61 bear on geothermal history and indicate that the section down to at least $2,500 \mathrm{~m}(8,000 \mathrm{ft})$ is thermally immature and is unlikely to have yielded 


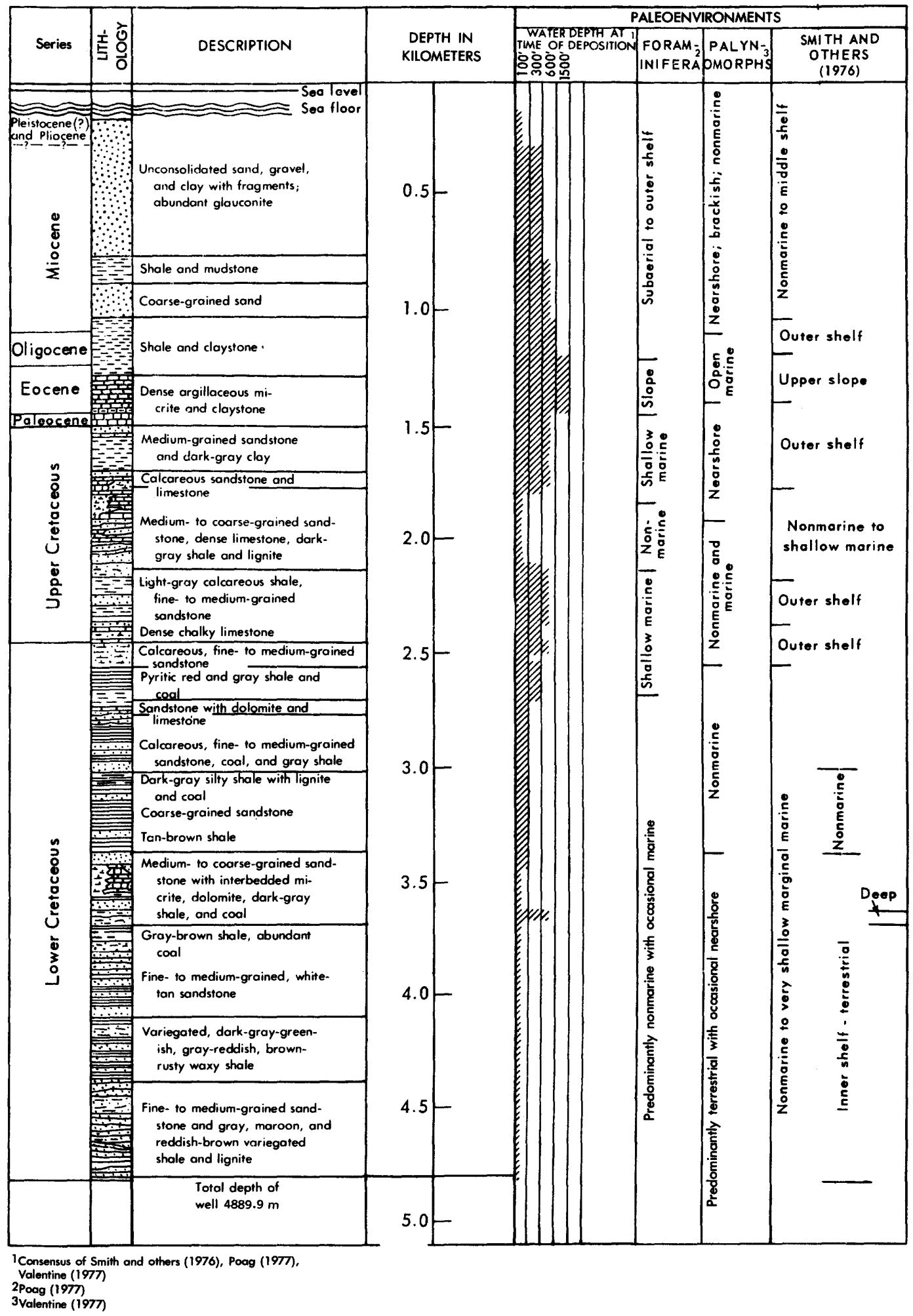

FIGURE 59.-Generalized plot of lithologies and depositional environments of sediments in the COST No. B-2 well. Modified from Smith and others (1976). 
DENSITY LOG POROSITY, IN PERCENT

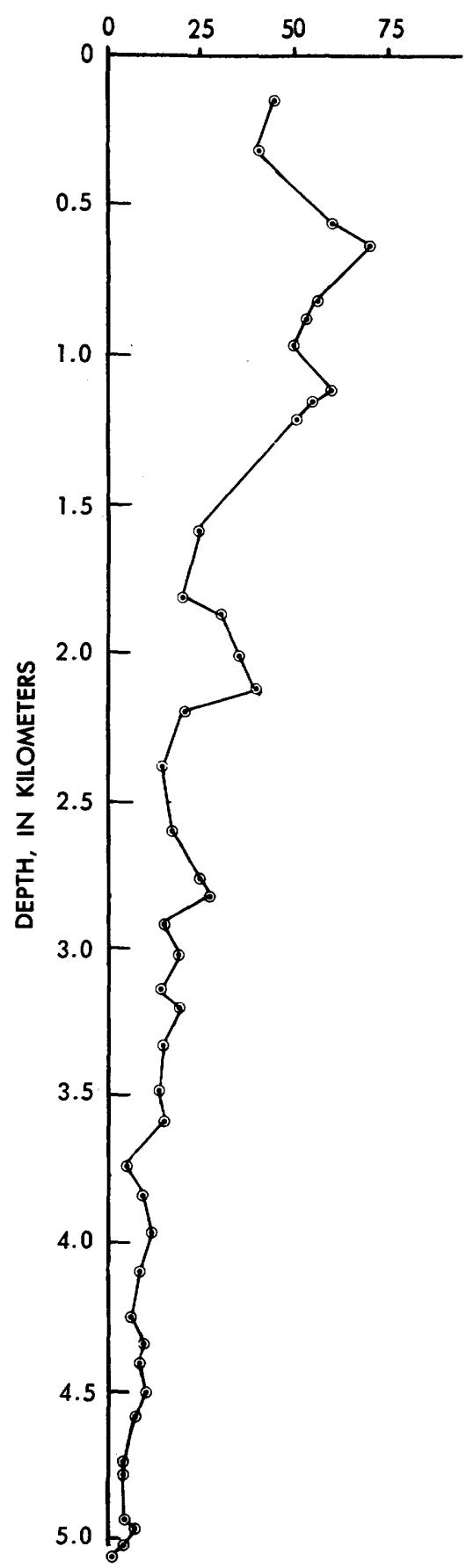

CORE POROSITY,

IN PERCENT

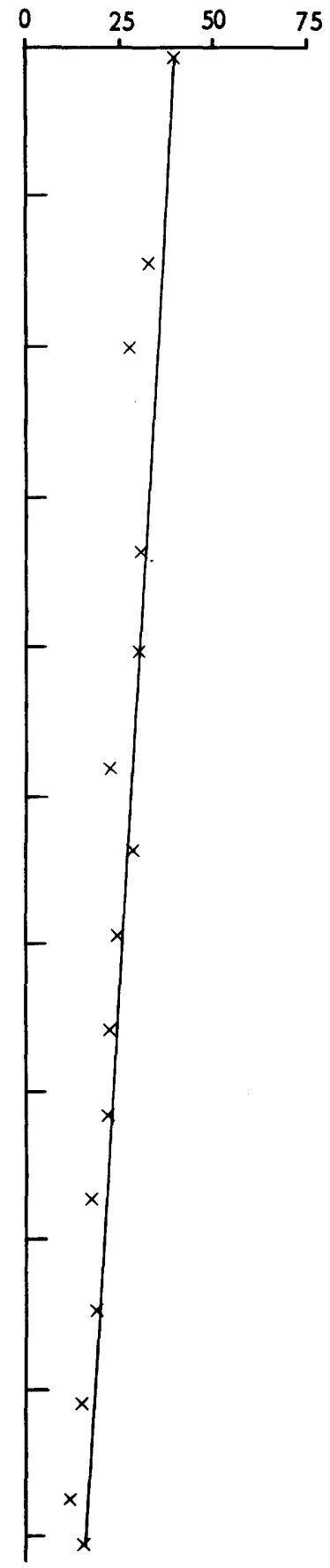

PERMEABILITY,

IN MILLIDARCIES

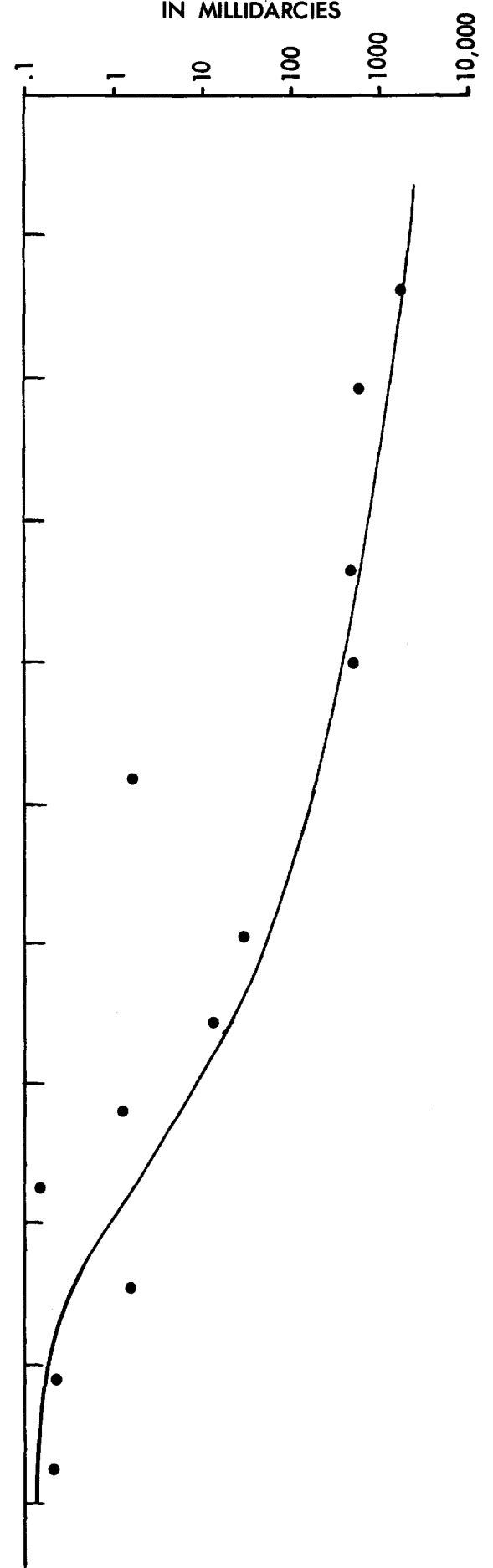

FIGURE 60. - Comparison of density log curve of porosity (from Scholle, 1977a, fig. 5) with measured core porosities and empirically determined permeabilities (from Core Laboratories, Inc., as given by Smith and others, 1976) in the COST No. B-2 well. 
hydrocarbons other than biogenic methane. Data from the various analytical techniques are interpreted to indicate different degrees of maturity for the section below $2,500 \mathrm{~m}(8,000 \mathrm{ft})$. The techniques based on observations of visible organic matter indicate moderate to full thermal maturity below 2,500 $\mathrm{m}(8,000 \mathrm{ft})$. For example, vitrinite reflectance values of $0.45-0.50$, found at about $2,500 \mathrm{~m}(8,000 \mathrm{ft})$ in the COST No. B-2 well, are generally taken as marking the earliest onset of liquid-hydrocarbon generation (Bartenstein and Teichmüller, 1974; Hood and others, 1975; Vassoyevich and others, 1970). Likewise, vitrinite reflectance values of $0.6-0.7$ and sapropelmaturation values of 2.5-3.0, found below $3,700 \mathrm{~m}$ $(12,000 \mathrm{ft})$, mark the peak rate of liquidhydrocarbon formation. Thus, such data and the present temperature profile in the well indicate that significant liquid hydrocarbons could have been generated below about 2,500 $\mathrm{m}(8,000 \mathrm{ft}$.).

Geochemical analyses of disseminated organic matter yield a somewhat different picture. Studies of extractable organic matter presented by Claypool and others (1977), Geochem Laboratories, Inc. (written commun., 1976), and Smith and others (1976) indicate that none of the sediments, not even those below $2,500 \mathrm{~m}(8,000 \mathrm{ft})$, are fully mature with respect to liquid-hydrocarbon generation. These authors concluded that although significant amounts of gaseous hydrocarbons may have been generated, large amounts of liquidpetroleum hydrocarbons have not yet been generated.

These differences in apparent maturity found by means of visual and geochemical techniques are not easily explained. Considerable disagreement still exists about the exact time-temperature relations needed for oil formation and the effect of type of organic matter and other factors upon rates of formation (for example, see Tissot and others, 1974). Thus, the noted discrepancies may be due to incorrect extrapolation of maturity versus oil-generation values from other basins. Indeed, recent workers have tended to place the main phase of oil generation at greater and greater depths and temperatures (for example, Hood and Castaño, 1974). On the basis of such work, little discrepancy exists between visual and geochemical analyses; both would indicate only marginal maturity with respect to liquid-petroleumhydrocarbon generation at the base of the COST No. B-2 well.
The type, as well as the amount, of organic matter present in the sediments plays a major role in the determination of the hydrocarbon potential of the section. In the COST No. B-2 well, some of the highest organic-carbon contents (as much as 11.5 percent) are present between 900 and $1,800 \mathrm{~m}$ $(3,000$ and $6,000 \mathrm{ft})$ and between 2,900 and $4,300 \mathrm{~m}$ $(9,500$ and $14,000 \mathrm{ft})$ (fig. 62). The interval between 2,900 and $4,300 \mathrm{~m}(9,500$ and $14,000 \mathrm{ft})$ also has the highest hydrocarbon and ${ }^{15} \mathrm{C}+$ extractable contents (fig. 62). This same part of the section has a very significant amount of coal, especially between 2,900 and $3,450 \mathrm{~m}(9,500$ and $11,300 \mathrm{ft})$ and between 3,780 and $4,300 \mathrm{~m}(12,400$ and $14,000 \mathrm{ft})$. The dominance of terrestrial over marine-derived organic matter in this interval is indicated by kerogen type, atomic $\mathrm{H} / \mathrm{C}$ ratio, and deviation of the ${ }^{14} \mathrm{C} /{ }^{12} \mathrm{C}$ ratio from that of the $\mathrm{PDB}$ marine carbonate standard (fig. 63); this dominance of terrestrial organic matter makes the generation of economic amounts of liquid-petroleum hydrocarbons unlikely but allows a high potential for generation of wet or dry gas.

Evidence for the presence of natural-gas deposits on the shelf comes from Texaco 598-1 well (discussed in "General Comments"). Some evidence for the presence of natural-gas deposits on the slope may come from AMCOR 6021 (fig. 1). The upper $305 \mathrm{~m}(1,000 \mathrm{ft})$ of sediment penetrated at this site contained significant amounts of the light hydrocarbons (methane, ethane, and propane). Although R. E. Miller and D. M. Schultz (written commun., 1976) believe that the methane is dominantly biogenic in orgin, some leakage from deeper natural-gas sources may exist. Several samples of gas-bearing mud from this borehole have been analyzed for stable carbon-isotopic composition of the methane. These preliminary results may indicate seepage from deeper parts of the section. However, because of the extremely small quantities of gas obtained and analyzed, the results should not be interpreted as unequivocal support for a thermogenic origin of methane (G. E. Claypool, written commun., 1976).

Extrapolation of the data from the COST No. B-2 well in a seaward direction within the Baltimore Canyon Trough is somewhat speculative. Although the section from $1,800 \mathrm{~m}(6,000 \mathrm{ft})$ to the base of the COST No. B-2 well was predominantly nonmarine to marginal marine, regional geology and seismic sections (Schlee, this volume) indicate that sections to the east and 


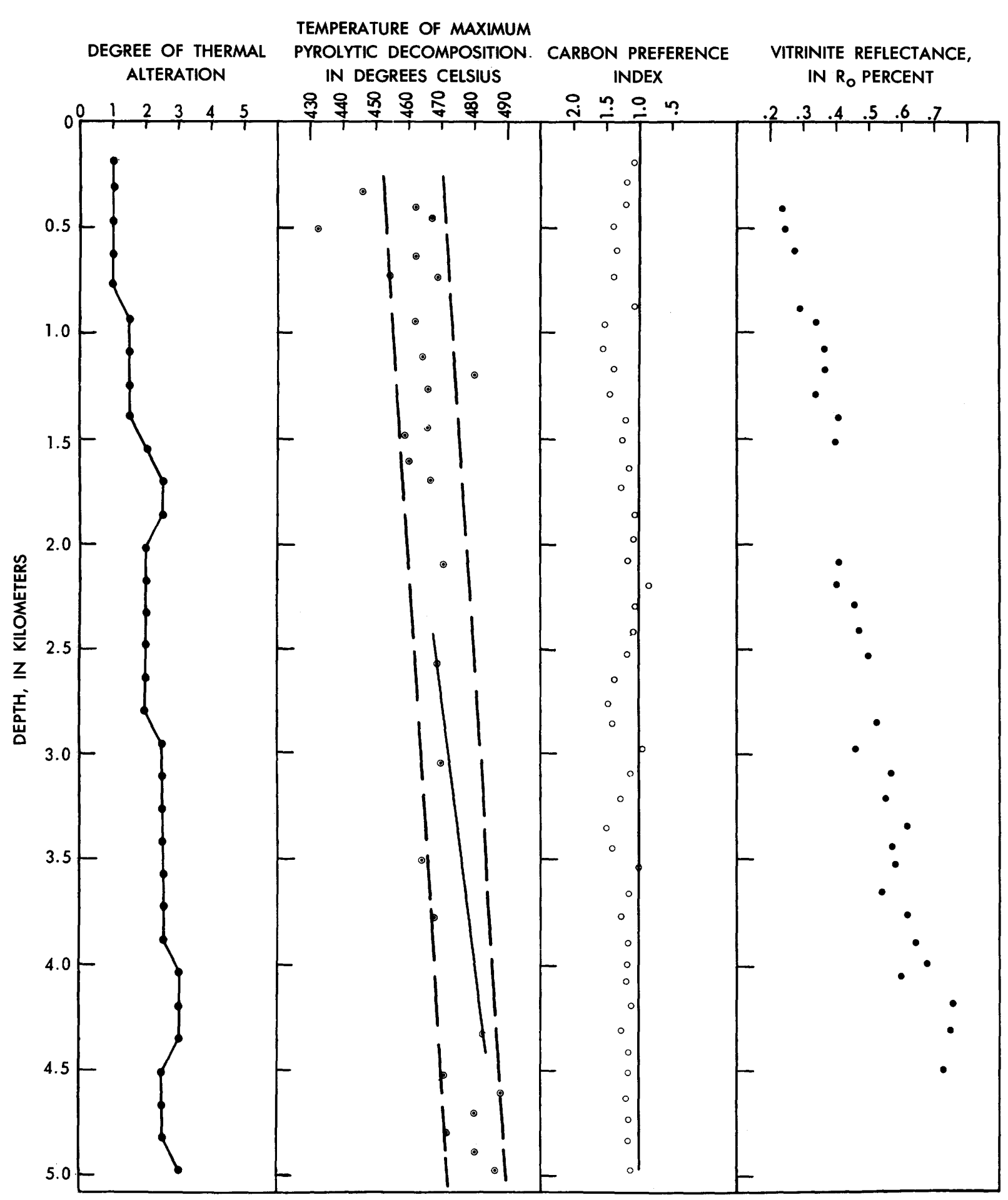

Figure 61.-Comparison of various measures of thermal maturity as a function of depth in the COST No. B-2 well. Degree of thermal alteration, from Robbins and Rhodehamel (1976); pyrolitic decomposition data, from Claypool and others (1977); carbon-preference index and vitrinite-reflectance data, from Geochem Laboratories, Inc., and Superior Oil Co., respectively, as reported in Smith and others (1976). 


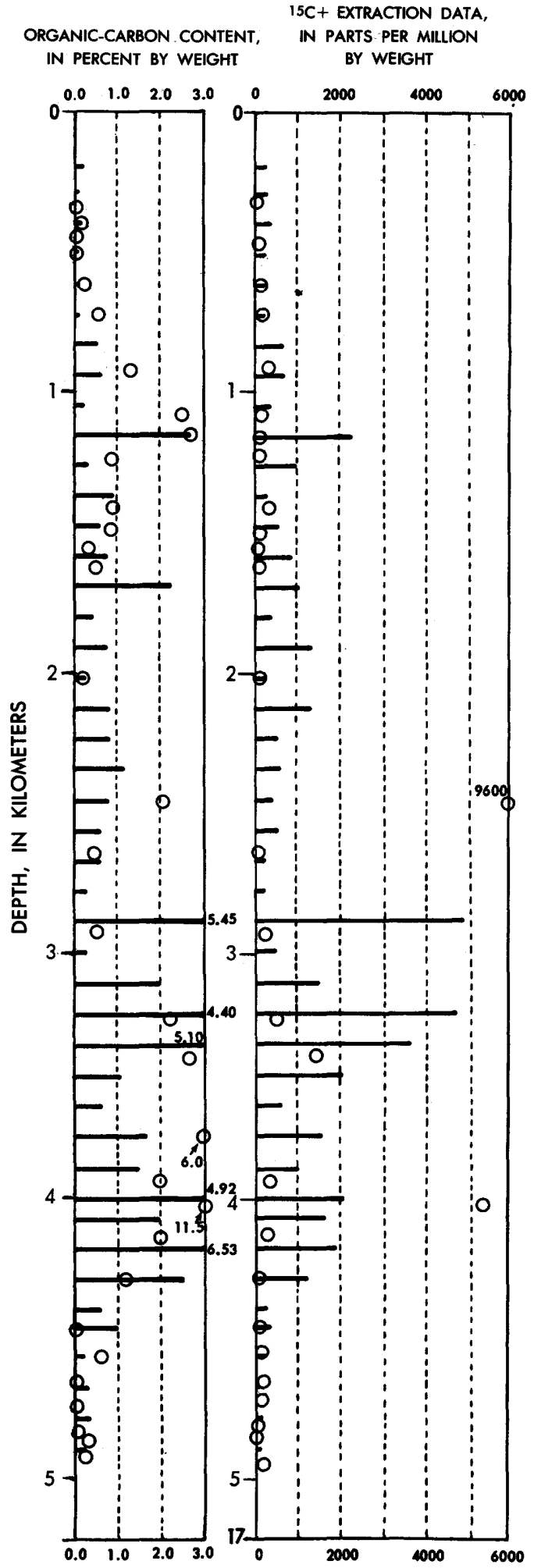

FiguRE 62. - Summary and comparison of analyses of organic content of sediments in the COST No. B-2 well. Geochem Laboratories, Inc., (written commun., 1976) data are shown as bars, whereas USGS data are shown as circles. southeast are likely to be more marine. A more fully marine section could contain source rock for oil generation. It could also contain cleaner, better sorted, perhaps somewhat less mineralogically immature sandstones that would have less susceptibility to clay cementation at depth than the rocks penetrated by the COST No. B-2 well. Sand units should also be thicker and more laterally continuous in the marginal to shallow marine environments than in the terrestrial equivalents in the COST No. B-2 well. Thick marine shales are undoubtedly present in the shallow marine to deeper marine sections and would act as seals as well as source rocks. These possible changes in lithology (shoreward, seaward, and laterally from the COST No. B-2 well) are discussed in detail by Poag (this volume) and Schlee (this volume). Possible patterns of thermal maturity are difficult to predict, but one might expect geothermal gradients to increase toward the young major rifts and possible intrusive rocks of the shelf edge and slope. Structures available for hydrocarbon entrapment in the Baltimore Canyon Trough area are discussed in the next two sections of this volume.

\section{SHELF}

By Robert E. Mattick and Kenneth C. Bayer

At Lease Sale No. 40, industry's high bids were for tracts near the crest of the Great Stone dome (fig. 64). Some of these bids may have been prompted by seismically recorded bright spots (high-amplitude reflections) or dim spots (lowamplitude reflections). At the crest of the dome, uppermost Lower Cretaceous and Upper Cretaceous beds are arched at least $350 \mathrm{~m}$. Measurements on cores from uppermost Lower Cretaceous sandstone penetrated in the COST No. B-2 well showed porosities as high as 28.7 percent and permeabilities as high as $1,220 \mathrm{mD}$ (Smith and others, 1976). Where these Lower Cretaceous sandstones are projected to the crest of the dome at depths of $1,800-2,200 \mathrm{~m}$, they could serve as good reservoirs, and could be sealed by overlying Upper Cretaceous shale (Scholle, this volume). Despite early optimism as to the hydrocarbon potential of the Great Stone dome, to date three dry holes, Shell 632-1, Houston Oil and Minerals 676-1, and Conoco 590-1, have been drilled downdip from the crest of the structure. Data from these wells have not yet been released. The crest of the structure is yet to be drilled. 
PYROLITIC

RELATIVE KEROGEN HYDROCARBON/ORGANIC

TYPE AND ABUNDANCE,

CARBON,

IN PERCENT

ATOMIC H/C RATIO

IN KEROGEN

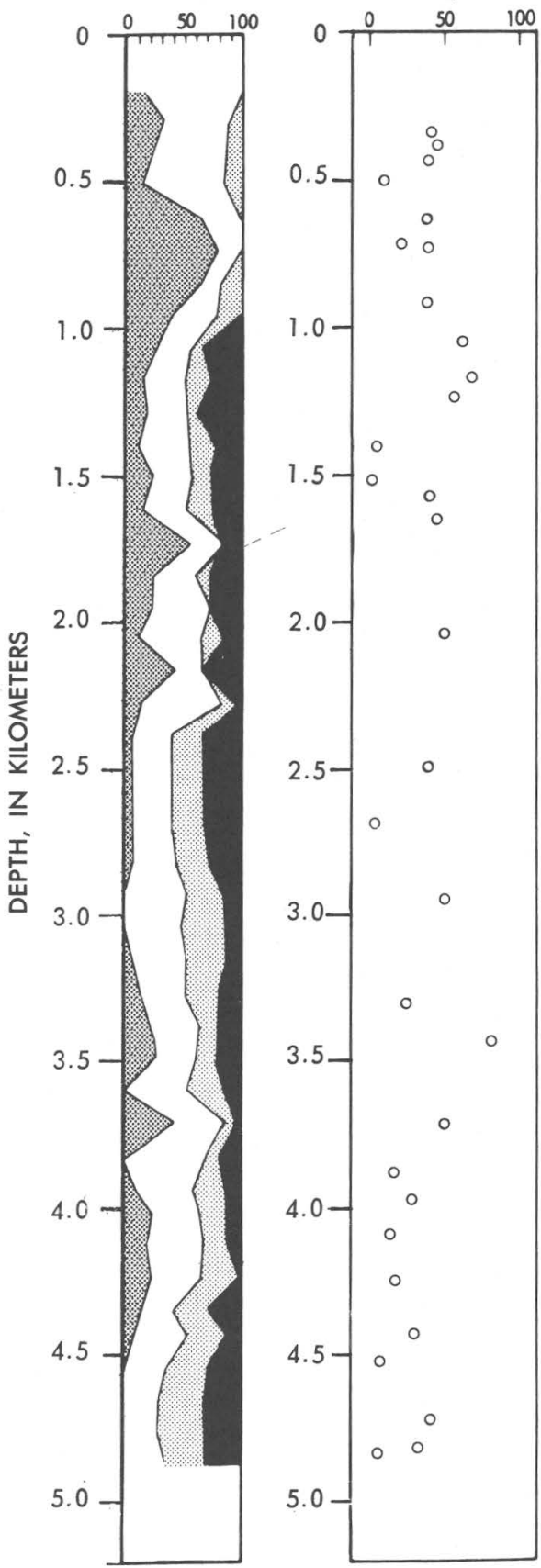

Amorphous

Herbaceous $\square$

Woody

Cooly


Total extract

FIGURE 63. - Summary and comparison of type of organic matter in samples from the COST No. B-2 well. Data in the first column are from Geochem Laboratories, Inc. (1976); second column, from Scholle (1977b); third column, from Amoco Production Co. (J. A. Momper, written commun., 1976); and the last column, from Phillips Petroleum Co. (J. G. Erdman, written commun., 1976). 

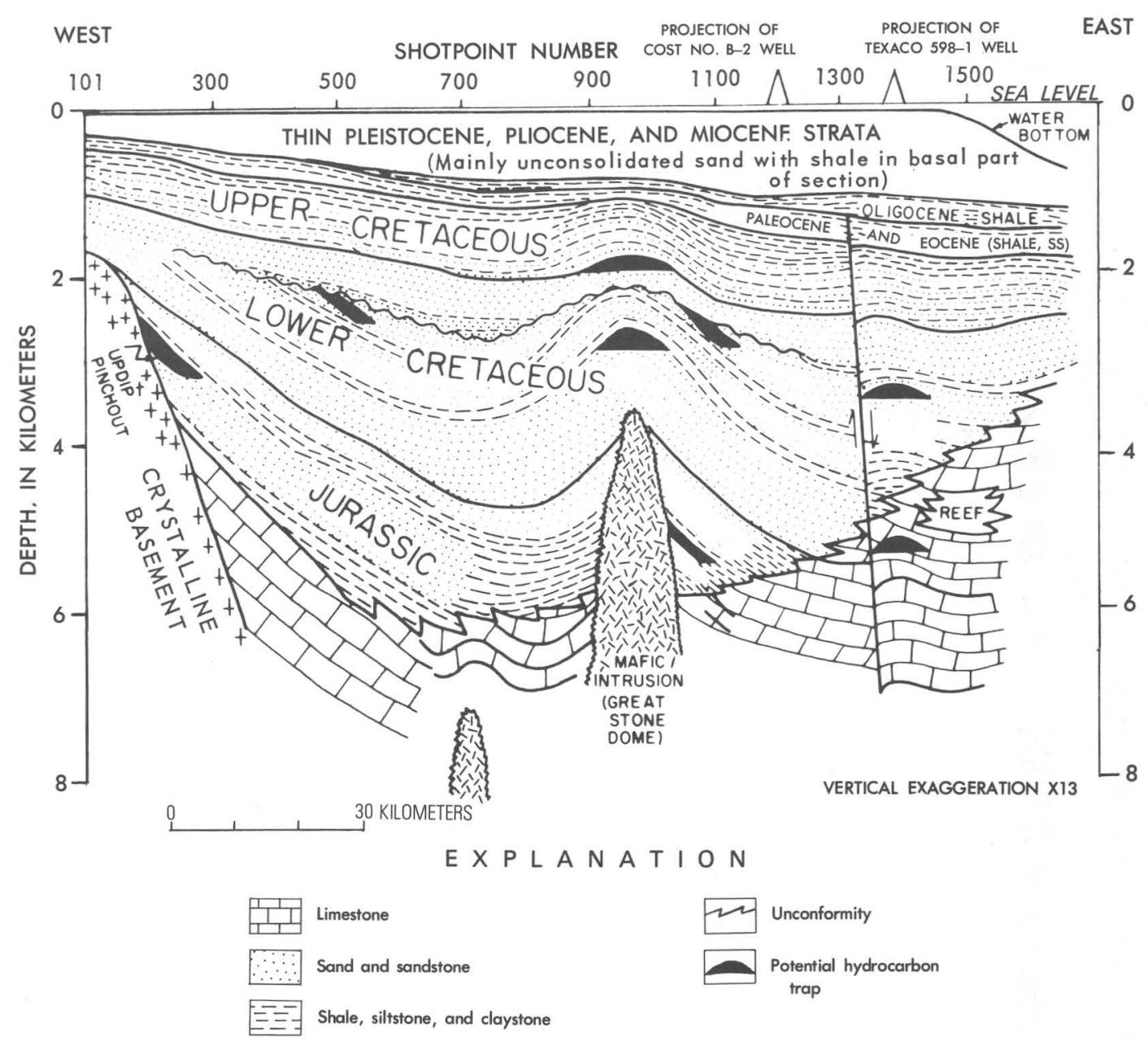

FIGURE 64.-Diagrammatic cross section illustrating potential hydrocarbon traps (shown in black) in the Baltimore Canyon Trough area. The figure is based on an interpretation of seismic profile 2. Location of this profile is shown in figure 1. SS, Sandstone.

Although the Great Stone dome is probably the largest intrusive body in the Baltimore Canyon Trough area, other smaller intrusive bodies may exist. For example, about $25 \mathrm{~km}$ west of the Great Stone dome, another piercement structure, at a depth of perhaps 7,300 m, appears on seismic records (fig. 64). Furthermore, in the northern and central Baltimore Canyon Trough area, a trend of positive magnetic anomalies parallels the seaward edge of the Continental Shelf (U.S. Geological Survey, 1976). These anomalies may represent intrusions emplaced along a zone of weakness near the shelf edge.

Other types of potential traps include unconformities, updip pinchouts, and fault-related traps (fig. 64). In areas where local unconformities are associated with intrusive features such as the Great Stone dome, the intersection of porous reservoir beds beneath an unconformity with adequate sealing beds above the unconformity could be a locus of hydrocarbon traps.

Updip pinchouts of Jurassic and possibly Lower Cretaceous clastic units against crystalline basement rock offer possibilities for stratigraphic traps. Significant lateral variations in porosity and permeability could likewise exist in marine carbonate rocks of Jurassic and Cretaceous age near the shelf edge. Such porosity and permeability changes could be found in fractured limestone and porous reef material and could include secondary porosity in back-reef dolomites. Downdip facies changes, from marine clastic to carbonate rocks and from marginal marine sandstone to shale, could also provide stratigraphic traps. The results from the COST No. B-2 well indicate that if such 


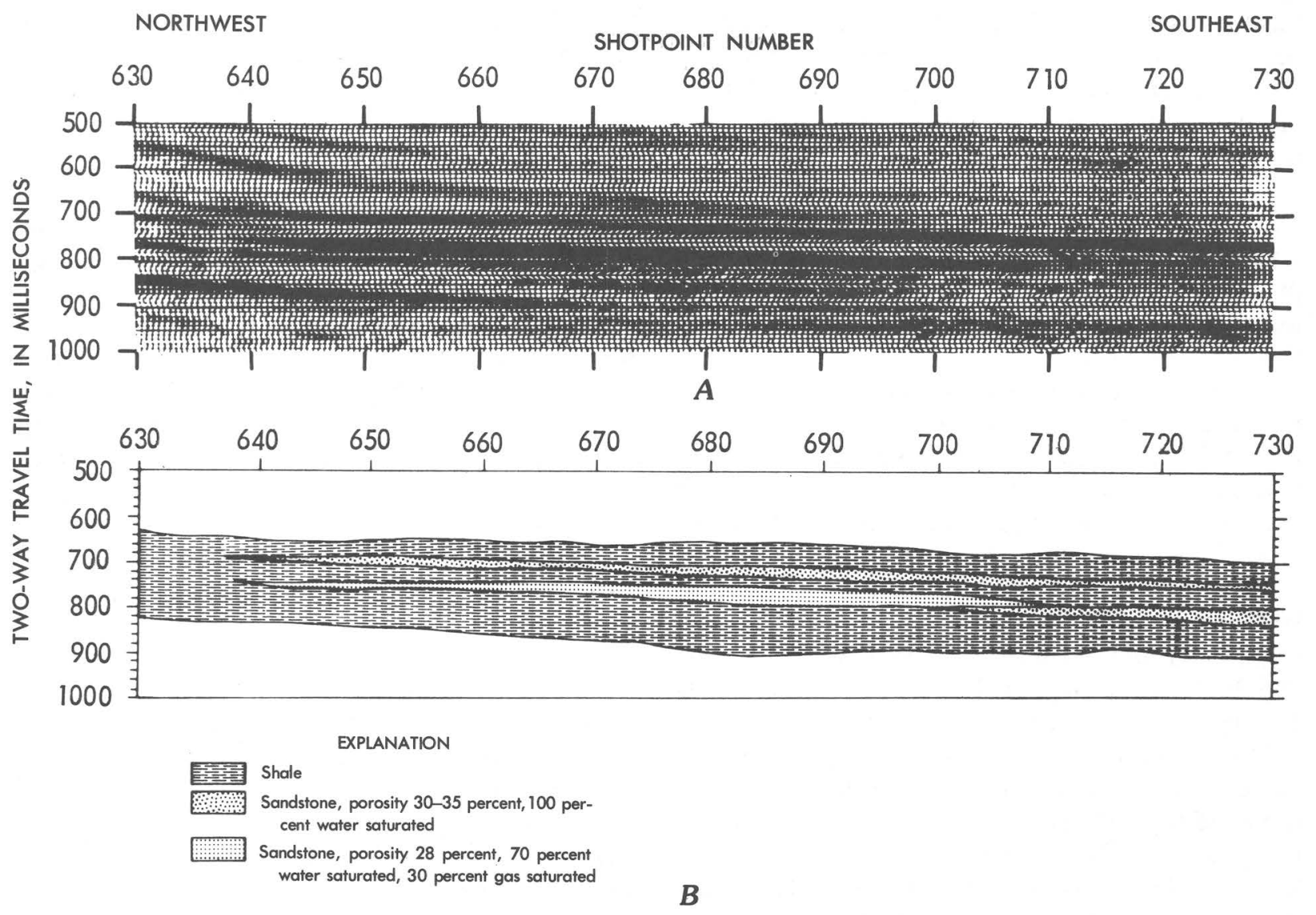

FIGURE 65.-Geologic model derived from seismic bright spot. $A$, Section of seismic record recorded between shotpoints 630 and $730(10 \mathrm{~km})$ on seismic profile 2 in the Baltimore Canyon Trough. Record has been processed to preserve the true amplitude of reflections. A bright spot is the darkened horizon at $0.8 \mathrm{~s}$ (depth of $620 \mathrm{~m}$ ). $B$, Geologic model derived from the seismic section by Brad Pitney of Digicon Geophysical Corp., Houston, Tex.

traps exist, they would most likely be very near the edge of the Continental Shelf.

Seismic evidence indicates that at least one major down-to-the-basin fault exists near the shelf edge in the Baltimore Canyon Trough area. The first well to discover natural gas in the Baltimore Canyon Trough (Texaco 598-1) is on the downthrown side of this fault (fig. 64). Whether such faulting is widespread and might be associated with hydrocarbon traps is unknown at present.

Evidence of gas accumulation is sometimes given by high-amplitude reflections (bright spots) from the reservoir containing the gas. The change in velocity caused by gas accumulation gives rise not only to bright spots but also to secondary effects, such as delays of deeper reflections and changes in reflection character near the boundary of the reservoir. A geologic model derived from an amplitude anomaly is shown in figure 65. If our estimates of the poorly understood lithologies are correct, the bright spot recorded at about $0.8 \mathrm{~s}$ is from the base of a gas sand $60 \mathrm{~m}$ thick and enclosed in shale. On the basis of amplitude of the reflection, the porosity of the gas sand is estimated to be 28 percent; the water saturation is estimated to be 70 percent, and the gas saturation, 30 percent. The apparent ratio of water saturation to gas saturation indicates a dirty sand having small likelihood of commercial production even if the anomaly is caused by natural gas rather than organically derived methane.

\section{SLOPE}

By Robert E. Mattick, Peter A. Scholle, and O. W. GIRARD, Jr.

\section{ORGANIC MATTER IN SLOPE SEDIMENTS}

Even though present-day sediments of the U.S. Atlantic lower slope and rise can be expected to 
have a relatively low content of peserved organic material, older sediments from similar paleobathymetric positions could be significantly rich in organic carbon (Mattick and others, 1978). Core samples from AMCOR 6021, drilled on the slope off New Jersey (fig. 1), contained significant amounts of methane, ethane, and propane (Hathaway and others, 1976). Although the methane is probably dominantly biogenic in origin, some leakage from deeper natural gas sources may exist (Scholle, this volume).

One of the most interesting speculations about potential source rocks beneath the present lower rise and abyssal plain is concerned with the thick (200-300 m) black hemipelagic shale of Cretaceous age that is rich in organic material and that has been found by drilling at many DSDP (Deep Sea Drilling Project) sites in the Atlantic. Lancelot, Hathaway, and Hollister (1972) discussed the total organic content of this shale from DSDP holes 101 and 105-one shale sample contained as much as 14.8 percent organic material.

Analysis of four samples of similar black shale of Albian and Aptian age from DSDP hole 391 (Geotimes, 1976) in the Blake Basin provided encouraging, but not optimistic, results. According to G. E. Claypool (USGS, written commun., 1976), all the samples are thermally immature, but at least one of the samples contains a sufficient amount of proper organic constituents to constitute a source bed if it were buried to depths of about $3 \mathrm{~km}$. The results of his analysis are shown in table 4.

Apparently, a reducing environment was widespread in the early Atlantic from Neocomian time, and data from DSDP cores and onshore samples (Scholle and Arthur, 1976) indicate that another reducing environment was widespread during the late Cenomanian and Turonian. Whether the shale beds penetrated by the DSDP holes exist beneath the U.S. Atlantic Slope and could have been a source of petroleum is unknown, even though small quantities of light extractable hydrocarbons were "distilled" by the injection of diabase sills into similar black shales off the coast of northwest Africa (Geotimes, 1975). With this one exception, the Cretaceous shale, where found by drilling, has never been subjected to high enough temperatures to generate significant quantities of petroleum. If, however, these rocks were deposited beneath the present upper rise and lower slope, sufficiently high temperatures could have been reached at depth. The temperature-gradient data of Robbins and Rhodehamel (1976) combined with the thermal window of Pusey (1973) suggest that petroleum could be generated beneath the rise between 2.5 and $5 \mathrm{~km}$ below the water-sediment interface.

\section{RESERVOIR ROCK ON THE SLOPE}

The present-day Continental Shelf is mantled by quartzose sand and some gravel brought there during lowered sea level in the Pleistocene and reworked during the Holocene (Schlee, 1973; Hollister, 1973). Seaward, on the slope and upper rise, terrigenous material becomes less dominant, and biogenic carbonate material forms a major sediment fraction (Hülseman, 1967; Milliman and others, 1972). According to Curray (1975), much of the present-day sediment on the continental margins is relict from lowered sea levels of the Pleistocene and is not in equilibrium with the current environment. Therefore, in order to infer past sediment-distribution patterns, especially the distribution of potential reservoir lithologies, the rock record and the processes that influence sediment distribution in deep-water environments must be examined.

TABLE 4.-Summary of combustion and thermal analysis of Cretaceous sapropels collected during DSDP Leg 44 from site 391, Blake Basin

[From George Claypool, USGS (written commun., 1976)]

\begin{tabular}{|c|c|c|c|c|c|c|}
\hline \multirow{3}{*}{ Sample } & \multirow{3}{*}{ Depth $(m)$} & \multirow{3}{*}{$\begin{array}{c}\text { Organic carbon } \\
\text { (weight percent) }\end{array}$} & \multicolumn{4}{|c|}{ Thermal analysis/pyrolysis } \\
\hline & & & \multicolumn{2}{|c|}{ Pyrolytic oil yield } & \multirow{2}{*}{$\begin{array}{l}\text { Oil yield as percent- } \\
\text { age of organic carbon }\end{array}$} & \multirow{2}{*}{$\begin{array}{c}\text { Oil content }{ }^{1} \\
\text { (weight, in ppm) }\end{array}$} \\
\hline & & & Gallons per ton & Weight percent & & \\
\hline 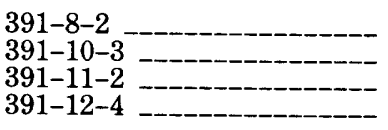 & $\begin{array}{l}785 \\
901 \\
927 \\
958\end{array}$ & $\begin{array}{r}0.2 \\
2.5 \\
.3 \\
1.2\end{array}$ & $\begin{array}{r}0.05 \\
1.98 \\
.02 \\
.16\end{array}$ & $\begin{array}{c}0.019 \\
.76 \\
.008 \\
.062\end{array}$ & $\begin{array}{r}9.5 \\
30.4 \\
2.7 \\
5.2\end{array}$ & $\begin{array}{r}23 \\
122 \\
6 \\
31\end{array}$ \\
\hline
\end{tabular}

${ }^{1} 0^{\circ}-350^{\circ} \mathrm{C}$ part of hydrogen-flame-ionization detector (HFID) response. 
Sediment transport from shallow-water to deepwater environments is primarily by (1) turbidity currents, (2) turbid-layer transport, and (3) slumping and sliding. Of these mechanisms, turbidity currents transport significant amounts of potential reservoir-rock material, such as sand and perhaps some gravel, to deep-water environments. The sediments transported by turbidity currents, however, tend to bypass the slope and are deposited on the rise and abyssal plain in large submarine fans at the mouths of submarine canyons.

In contrast, turbid layers, which are low-velocity clouds of muddy water immediately above the sea floor, transport large quantities of fine-grained sediment across the shelf to the slope. In general, the fine-grained material transported in turbid layers will not form effective reservoir rocks.

Submarine slumping and sliding is most prevalent on the Continental Slope. However, because this process involves sediments already deposited on the slope, most of the slumped material may consist of fine-grained deep-water sediments. In contrast, slumps and slides along shelf margins dominated by reef deposition could be a means of transporting potential reservoir rocks into deeper water environments.

Bottom sampling and drill-hole data indicate that Cenozoic sediments deposited on the present slope and upper rise, except Pleistocene sand, do not contain significant amounts of favorable reservoir material. In one of five holes recently drilled on the slope (Hathaway and others, 1976), well-sorted and round quartzose sand of Pleistocene age was penetrated at a depth of $76 \mathrm{~m}$. In a second hole, medium to coarse sand of Pleistocene age was penetrated at a depth of $104 \mathrm{~m}$. Apparently, the Pleistocene sands were deposited directly on the slope at a time when the Continental Shelf was above sea level. However, according to Emery and Uchupi (1972), most of the sediments sampled to date on the U.S. Atlantic Continental Slope are green silty clays and clayey silts.

The deepest hole drilled to date on the Continental Rise north of Cape Hatteras is DSDP hole 106. The cores recovered from this hole were mainly Pleistocene clay, silt, and fine sand to a depth of about $350 \mathrm{~m}$ and little if any material coarser than clay from $350 \mathrm{~m}$ to the bottom of the hole at 1,015 m (Geotimes, 1970).

This discussion suggests that the reservoir characteristics of Cenozoic deposits (except the Pleistocene sand and perhaps deposits in canyon axes where sand was funneled by gravitational flow) on the present slope and rise are poor. However, we don't believe that the entire U.S. Atlantic Slope province lacks hydrocarbon potential simply on the basis of conclusions about the Cenozoic section. According to Schlee and others (1976), the present slope surface is a fairly recent bathymetric feature, and we point out below in this section that the shelf edge during Early Cretaceous time probably was $20-30 \mathrm{~km}$ seaward of its present position. The present Continental Slope, therefore could be underlain by coarse-grained sediments deposited on an older shelf surface. If the slope is underlain by coarse-grained sediments, the younger clays deposited on the present slope surface could provide an impermeable seal for Cretaceous and Jurassic reservoirs. Peter Vail (written commun., 1976) has inferred several worldwide drops in sea level comparable to those that took place during the Pleistocene. Indeed, Cretaceous sea-level fluctuations have been estimated to involve changes in water depth of more than $500 \mathrm{~m}$ (Hays and Pitman, 1973)-far greater than any Pleistocene oscillations. By analogy with the Pleistocene, reservoir material may have been deposited on the slope during these periods of lowered sea level.

\section{POTENTIAL HYDROCARBON TRAPS ON THE SLOPE}

As indicated by Poag (this volume) and Schlee (this volume), what is now the Continental Slope is probably underlain by sequences of Lower Cretaceous and Jurassic sedimentary rocks deposited on a carbonate platform or possibly atop high-standing basement blocks (figs. 66 and 67). The landward shift of the present shelf edge relative to the buried paleoshelf edge is about $20-30 \mathrm{~km}$.

During Early Cretaceous or Late Jurassic time, reef growth apparently began at the edge of the paleoshelf (fig. 67). As the continental margin slowly subsided, reef buildup reached a height of perhaps 2,500 m. Deltaic sands and some shales were deposited contemporaneously in the backreef area as indicated by the Lower Cretaceous sandstones penetrated in the COST No. B-2 well. Because delta progradation and contemporaneous reef growth are, in general, incompatible, the presence or absence of carbonate deposits in local areas in the Early Cretaceous probably depended largely on the volume of local terrigenous input. On seismic sections, reefs appear to be discontinuous, and the eastern margin of the Baltimore 


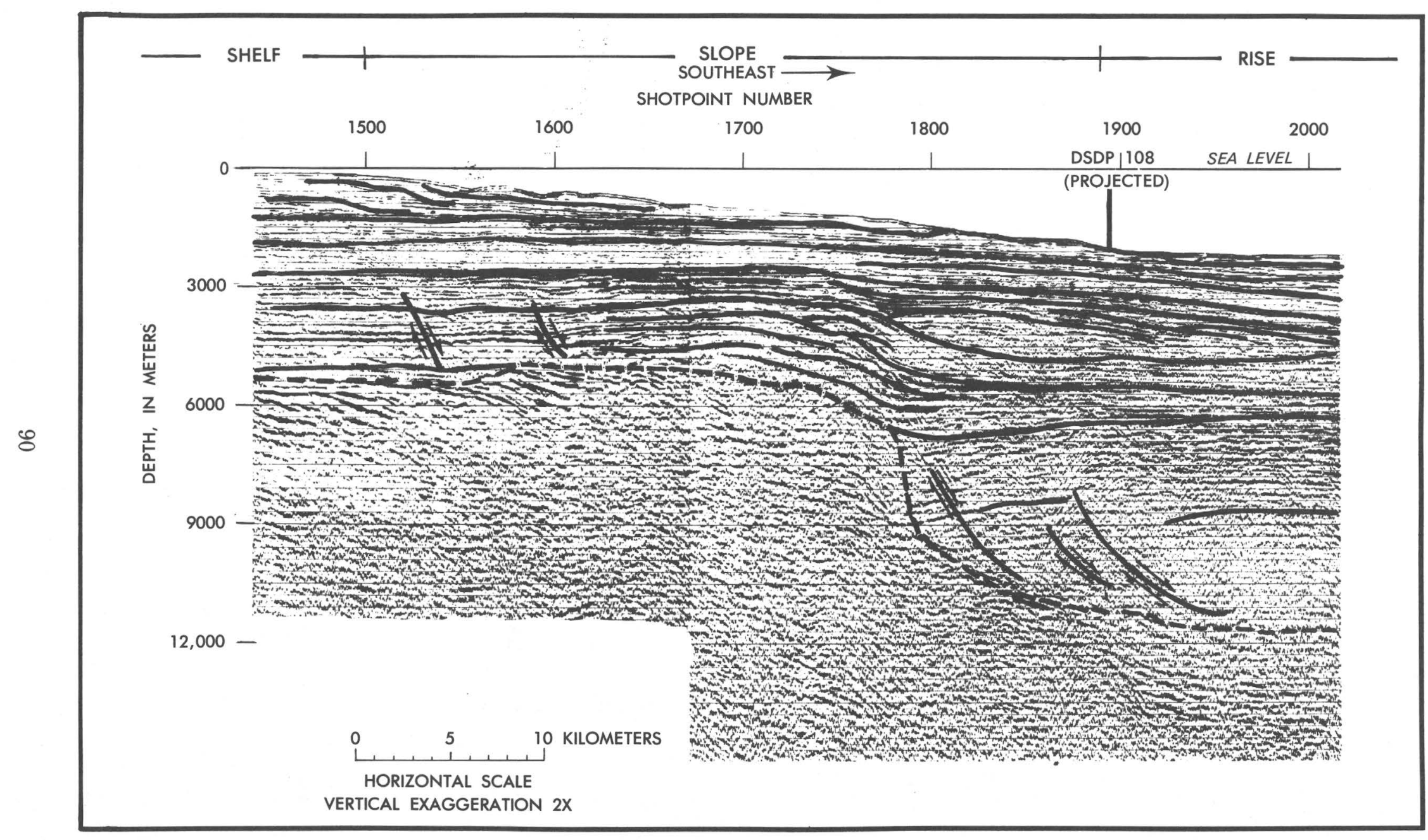

FIGURE 66. - Interpreted depth section computed along seismic-reflection line 2 (fig. 1) between shotpoints 1500 and 2000. The dashed line represents acoustic basement. This depth section was provided by Richard Wise of Digicon Geophysical Corporation, Houston, Tex. 


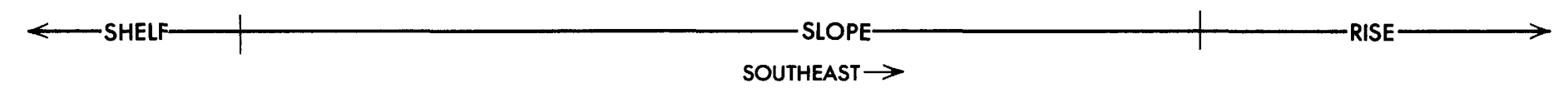

SHOTPOINT NUMBER

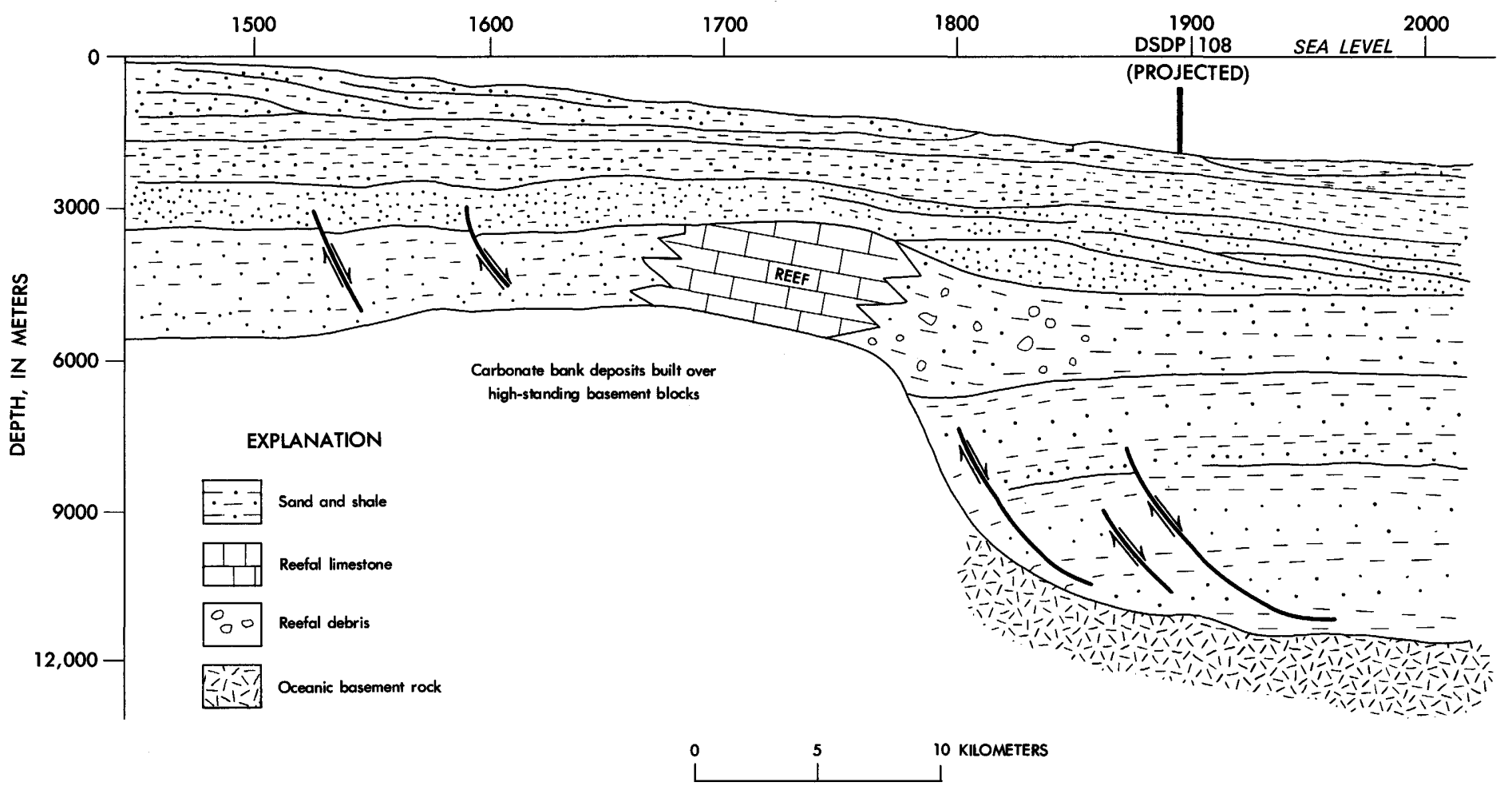

FIGURE 67.-A geologic interpretation of the part of seismic profile 2 shown in figure 66. 
Canyon Trough section thus shows a relatively narrow and restricted trend of bank-margin carbonate rocks. Some of the deltaic sand may have been funneled through channels in the reef contemporaneously with reef growth or may have been swept over the reef as sheet deposits during periodic fluctuations of sea level. Thus, clastic terrigenous sand, fine-grained pelagic and hemipelagic material, and reef debris were probably all deposited at the base of the paleoshelf. Near the end of Early Cretaceous time, the reef could have been exposed and later could have been buried by an influx of sediment.

The lower half $(5-6 \mathrm{~km})$ of the thick sedimentary wedge at the base of the paleoshelf and underlying the present Continental Rise probably consists chiefly of Upper Jurassic terrigenous sedimentary rocks. Although little evidence exists to support the contention, sediments that were accumulating in the Baltimore Canyon Trough behind a shelfedge ridge during the Early Jurassic may have over-topped the ridge and been deposited at its base. The thickness of these inferred Jurassic and Lower Cretaceous sedimentary rocks indicates that they were deposited at high sedimentation rates of $100-300 \mathrm{~m} / 10^{6} \mathrm{yrs}$. These rates are one to two orders of magnitude higher than normal hemipelagic or pelagic sedimentation rates of red clays, siliceous oozes, or calcareous oozes (for example of sedimentation rates, see Berger, 1974) but are in line with normal rates of terrigenous-mud and turbidite deposition (Fischer, 1969). The low velocity $(4-5 \mathrm{~km} / \mathrm{s})$ at which seismic waves travel through these deeply buried sediments indicates a scarcity of carbonate rocks and possibly good porosity throughout the entire section. The basal part of this section could contain a significant thickness of continental Triassic red beds similar to the deposits in down-faulted Triassic and Jurassic(?) basins beneath the Coastal Plain.

The importance of the paleoshelf edge feature, as far as petroleum is concerned, is the fact that it is a large "high," which could contain zones of very porous carbonate rock in both reefal and carbonate platform material and which is bordered on both its landward and seaward flanks by thick sequences of rocks possibly rich in organic material. Furthermore, thick overlying shale beds could provide a relatively impermeable seal needed to trap the migrating fluids. In order for the paleoshelf high to have trapped the migrating fluids, paths of migration from the proposed source beds to the suspected traps must exist. Turbidite deposits usually consist of thin beds of alternating finegrained material and coarser sand. These thin sand beds are generally continuous over large areas and hence, hydrocarbons could have migrated essentially updip, but possibly down section, to reservoir rocks in the Mesozoic shelf high. Down-to-the-basin growth faults, which are beneath the present rise (fig. 67), may have interrupted the flow of migrating fluids, but in places, migration may have followed paths along these faults or through large fan complexes. Similarly, on the landward flank of the paleoshelf complex, beds of deltaic sand, although less continuous than the turbidite sands, could have provided migration paths to charge this Mesozoic shelf high.

Whether hydrocarbons, once they migrated into the paleoshelf high, would have been trapped or whether they would have leaked out is not known. Shales of Cretaceous and Cenozoic age are inferred to overlie the paleoshelf. If the fluids migrated after the deposition of these shales, the shales could provide the necessary impermeable seal above the paleoshelf margin high. Carbonate rocks can act as a seal under certain diagenetic conditions and as a reservoir under other diagenetic conditions.

If hydrocarbons have been trapped in the paleoshelf high, we could be looking at very significant traps. According to Moody (1975), almost 40 percent of the world's oil reserves are in carbonate rocks. The reef trends in the Edwards Limestone of Texas and the El Abra-Tamaulipas Formation of Mexico provide good examples for comparison (Bebout and Loucks, 1974; Enos, 1974; Rose, 1963).

Excellent reservoirs may exist in back-reef, reef, or fore-reef facies. Back-reef sediments may have been deposited at or near sea level, thus allowing evaporite formation, dolomitization, leaching, and other mechanisms for forming secondary porosity. Such dolomitized sediments have been recovered by dredging from the Blake Escarpment (Sheridan and others, 1969). The reef, although probably initially cemented, could have formed and developed excellent secondary porosity if exposed to subaerial erosion. According to the Scientific Party aboard Glomar Challenger for Leg 44 (Geotimes, 1976, p. 24), Lower Cretaceous reefs, banks, and back-reef facies in DSDP holes 390, 392, and 392A all showed "evidence of subaerial weathering and leaching by fresh water." In addition, as the Late Cretaceous appears to have been a time of major transgression, a good possibility exists that fine- 
grained rocks (seals) may overlie Lower Cretaceous reefs.

Possible traps, other than those associated with carbonate facies of the paleoshelf, include (1) a structural high caused by draping of Upper Cretaceous sedimentary rocks over the Lower Cretaceous shelf edge, (2) pinchouts of Lower Cretaceous and Jurassic sedimentary rocks that were deposited at the base of the paleoshelf, (3) fault-related traps beneath the present-day slope, (4) abandoned canyon-fan complexes, and (5) traps associated with diapiric features on the present slope.

Above the Lower Cretaceous shelf edge, Upper Cretaceous horizons are arched as much as $300 \mathrm{~m}$ (fig. 67). This structural high, probably caused by draping of Upper Cretaceous sedimentary rocks over the Lower Cretaceous shelf edge or possibly over high-standing basement blocks, would be in a good stratigraphic position to retain hydrocarbons that may have migrated updip from sediment facies on the lower slope and rise. Deltaic sand deposited on the Lower Cretaceous shelf edge (Rhodehamel, 1977) could provide excellent reservoir material. In large delta areas such as the Baltimore Canyon Trough, clastic input could have overwhelmed the Cretaceous rise in sea level resulting in the deposition of massive sand sheets out to the shelf edge. If this happened, then Upper Cretaceous coarse-grained sand could interfinger with shale below the present slope area.

At the base of the paleoshelf, coarse-grained Lower Cretaceous and Jurassic sedimentary rocks probably pinch out against the finer grained rocks or dense carbonate rocks that make up the paleoshelf. These stratigraphic traps, although difficult to locate by geophysical techniques, should not be overlooked. Again, migration of hydrocarbons from sediment facies below the present rise and abyssal plain could contribute significant amounts of hydrocarbons to traps near the base of the paleoshelf. In addition, good possibilities exist for fault-related traps in this area. Significant growth faults (contrast this interpretation of faulting with that of Grow and Klitgord, this volume) mapped on seismic sections, extend from near the basement surface, at the base of the paleoshelf, high up into the sedimentary section (fig. 67).

If major regressions of the sea took place during Cretaceous and Jurassic time (as they did during Pleistocene), the ancestral Continental Slope may have been traversed by many deeply incised submarine canyons during those periods. These canyons, later abandoned, presumably would have been filled by coarse sediment and possibly covered by fine-grained material. This type of trap could be located by geophysical methods. Associated with these canyons would be major submarine-fan deposits. By analogy with modern areas, these could have many channels of coarse-grained sediment in between areas of finer grained "overbank" sediment. The grain-flow and turbidite sands of the Atlantic margin, unlike those in many turbidite settings, would not have a graywacke or litharenite composition but would likely be of subarkosic composition. Subarkosic rocks have greater diagenetic stability and a greater chance for high porosities and permeabilities than do graywackes or litharenites.

Diapirs under the present slope could be the continuation of a diapir complex known to underlie the slope beneath the Scotian margin off eastern Canada, where Jurassic evaporite deposits have been drilled (Schlee, Martin, and others, 1977). At the present time, we can only speculate on the origin and potential of such structures on the U.S. Atlantic margin. Beneath the Scotian Slope and Rise, such structures are large and common, but their oil and gas potential is yet untested.

\section{SUMMARY AND CONCLUSIONS}

\section{GEOLOGY}

The Baltimore Canyon Trough is an elongate, seaward-opening sedimentary basin filled by as much as $14 \mathrm{~km}$ of Mesozoic and Cenozoic sedimentary rocks. The deepest (oldest) part is mainly the outer and more northerly part of the trough. Apparently, the trough first formed mainly under the New Jersey shelf and gradually spread west and south as the area subsided after the rifting that formed the Atlantic basin. The trough is asymmetrical in cross section in that the slope of the basement is much less under the Coastal Plain than it is under the shelf where pronounced steepening (a hinge zone?) is present, particularly off New Jersey.

The oldest sedimentary rocks (Jurassic and Triassic) are essentially unsampled; their lithologies and environment of deposition have 
been interpreted (1) from seismic-reflection and seismic-refraction profiles, (2) by extrapolation from Coastal Plain sections, and (3) by analogy with deep wells drilled elsewhere on the Atlantic margin. Rocks of the Jurassic and Triassic Systems together are more than $8 \mathrm{~km}$ thick in a depocenter areally restricted to the northern part of the trough. The sequence thins in an irregular manner toward Long Island, where it fills grabens. It thins toward the New Jersey coastline over a short distance, but thinning toward the southern part of the trough is more gradual. Basal Jurassic and Triassic rocks are thought to be mainly nonmarine sedimentary rocks bedded with evaporite deposits. Obviously, marine waters were able to extend into the trough though they had restricted circulation. Indirect evidence that salt is in the basal Jurassic section comes from analogy with the Scotian Shelf and from high interstitial salinities in offshore core holes near Cape Hatteras. Direct evidence comes from the Houston Oil and Minerals 676-1 well, which penetrated salt at a depth of about $3.8 \mathrm{~km}$ (J. C. Hathaway, written commun., 1979).

During the Middle and Late Jurassic, more open marine conditions prevailed than in the Early Jurassic, and carbonate banks and reefs formed discontinuously along the seaward side of the shelf. Sand flats likely occupied the central part of the shelf, and these probably graded shoreward into nonmarine red beds that accumulated in a bordering coastal plain. Upper Jurassic rocks are largely thick nonmarine sands and silty shales in the nearshore and midshelf area but probably grade into thick marine carbonate rocks near the present shelf edge.

During the Cretaceous, the shelf was a much broader feature than during the Jurassic, though the accumulation of sediment was much less-between 4 and $5 \mathrm{~km}$ - and most of the sediment was deposited during the Early Cretaceous, to judge by the data from the COST No. B-2 well. The Cretaceous units show two main trends through time - a diminishing rate of sediment accumulation and an increase in marine character of sediments. During the Middle and Late Cretaceous, calcareous sand and mud buried the shelf-edge reefs and spilled across them into the oceanic basin as worldwide sea level reached a maximum.

Cenozoic deposits are broadly spread over the trough and adjacent Coastal Plain in overlapping sheets of marine and nonmarine sediment. The maximum thickness $(1.5 \mathrm{~km})$ of Cenozoic deposits, like that of Cretaceous deposits, is along the outer part of the present shelf, though the Cenozoic sedimentary section is much thinner than the Cretaceous section. Despite a broad trend toward gradual lowering of sea level during the Tertiary, subsidence in the Baltimore Canyon Trough area was sufficient to maintain a marine environment in much of the area. The chiefly marine regime was punctuated by short intervals of sea-level drop, as evidenced by erosion of parts of the shelf and by the presence of coastal-swamp and alluvial-plain deposits.

Highly calcareous sediments of Paleocene and Eocene age are known within, as well as both north and south of, the Baltimore Canyon Trough area. Latitudinally distinctive lithofacies and biofacies began to be deposited during this time period. Oligocene beds are widespread and are rich in shallow-water carbonate sediments and large foraminifers under the southern shelf. The absence of Oligocene beds from much of the northern Coastal Plain and the presence of shallow-water facies to the south suggest a major regressive cycle of deposition.

Deposition of clastic sediments increased during the Miocene and continued, although diminished, through the Pleistocene. Broad progradational sheets appear to have built up the shelf over the northern part of the trough during this time. During the Pliocene, a major delta complex, characterized by freshwater diatom assemblages, formed off Virginia and Maryland. Pleistocene sands and silts are especially thick on the Continental Slope; apparently density and turbidity flows have transported large volumes of shelf sediments onto the Continental Slope and Rise through shelf-edge canyons. The only significant accumulations of Holocene sediments are gray and white sands and silts along the coastline and green silty clays on the Continental Slope.

\section{PETROLEUM GEOLOGY}

We have discussed the petroleum geology of the Continental Shelf in terms of five factors: (1) source rocks, (2) temperatures sufficient to generate gas or oil, (3) reservoir rocks, (4) seals, and (5) traps or structures capable of entrapping migrating petroleum liquids or gases.

In the COST No. B-2 well, some of the highest organic-carbon contents are present between depths of 900 and 1,800 $\mathrm{m}$ and between 2,900 and 
$4,300 \mathrm{~m}$. The interval between 2,900 and $4,300 \mathrm{~m}$ also has significant amounts of coal and the highest contents of hydrocarbon and extractable ${ }^{15} \mathrm{C}+$. The dominance of terrestrial over marine-derived organic matter in this interval means that economic amounts of liquid petroleum hydrocarbons were probably not formed but that a high potential exists for generation of wet or dry gas. Some supporting evidence for the presence of natural-gas deposits on the slope comes from AMCOR 6021 , the upper $305 \mathrm{~m}$ of which penetrated sediments that contained methane, ethane, and propane. Direct evidence of natural-gas deposits on the shelf comes from the Texaco 598-1 well and the Gulf 857-1 well. During initial tests, natural gas flowed from the Texaco well at a rate of about $479,000 \mathrm{~m}^{3} /$ day from two zones.

Geochemical studies of the COST No. B-2 well have shown that the shelf area has a relatively low geothermal gradient today, and that it apparently has had a gradient as low or even lower throughout the Cretaceous to Holocene. Data from color alteration of visible organic matter, pyrolyticdecomposition temperatures, carbon-preference index, and vitrinite reflectance indicate that the section down to at least $2,500 \mathrm{~m}$ is thermally immature and is unlikely to have yielded hydrocarbons other than biogenic methane. Data from the various analytical techniques are interpreted to indicate different degrees of maturity for the sediments below $2,500 \mathrm{~m}$. The techniques based on observations of visible organic matter indicate moderate to full thermal maturity below $2,500 \mathrm{~m}$. Studies of extractable organic matter, however, indicate that none of the sediments, not even those below $2,500 \mathrm{~m}$, are fully mature with respect to liquid-hydrocarbon generation. These results indicate that although significant amounts of gaseous hydrocarbons may have been generated, large amounts of liquid-petroleum hydrocarbons have not yet been generated.

The COST No. B-2 well penetrated thick sections of potential reservoir rock. The section between 1,500 and $4,900 \mathrm{~m}$ consists of relatively thick sandstone units, some of which have significant reservoir potential. The reservoir quality of this sandstone, however, deteriorates consistently as depth increases, and in the section below 3,700 $\mathrm{m}$, few sandstones have more than $1 \mathrm{mD}$ permeability.

Shales were penetrated in the section at the COST No. B-2 well. These rocks could provide the necessary impermeable seal required to trap migrating fluids and gases, aithough in some intervals, the shales may be too thin to form effective hydrocarbon seals.

Although the sediments penetrated in the COST No. B-2 well were predominantly nonmarine to marginal marine, regional geology and seismic sections indicate that sections to the east and southeast probably are more marine. By analogy with the Scotian Shelf, a more fully marine section would be more likely than nonmarine to marginal marine sections to contain source rocks. Studies on the Scotian Shelf indicate that the percentage of amorphous organic material, which can be converted to petroleum at relatively low temperatures, tends to increase in the direction of deep-water environments. Petroleum could also have been generated under the present lower slope and rise in basin facies rich in organic matter and then could have migrated to reservoirs along the shelf edge. A more marine section could also imply cleaner, better sorted, perhaps somewhat less mineralogically immature sandstones, which would be less susceptible to clay cementation at depth. Sand units should also be thicker and more laterally continuous in a marginal to shallow marine environment than in the terrestrial equivalents found in the COST No. B-2 well. Possible patterns of thermal maturity are difficult to predict, but geothermal gradients might increase toward the shelf edge, where major faults and intrusions have been postulated.

On the shelf, potential hydrocarbon traps are associated with diapirs, drape structures over uplifted fault blocks, and faults. Seismic evidence suggests that although these potential traps are sparse under the inner shelf and midshelf areas, they are more common along the landward edge of the shelf-slope break. The largest structure mapped to date is the Great Stone dome. This structure, about $20 \mathrm{~km}$ in diameter, probably was caused by a mafic intrusion that resulted in the arching and erosion of at least $3,000 \mathrm{~m}$ of Jurassic and Lower Cretaceous strata. Lower and Upper Cretaceous strata having about $350 \mathrm{~m}$ of relief unconformably overlie older strata near the dome. On the flanks of the dome, potential traps include pinchouts of Lower and Upper Cretaceous strata and possibly deep Jurassic reservoirs that have updip seals provided by intrusive basement rock. To date, however, three dry holes, Shell 632-1, 
Houston Oil and Minerals 676-1, and Conoco $590-1$, have been drilled on the dome.

Seismic evidence indicates that at least one major down-to-the-ocean fault, involving Jurassic through Tertiary strata, exists on the landward side of the shelf edge in the Baltimore Canyon Trough area. The first natural-gas discovery on the U.S. Atlantic Coast-Texaco's 598-1 well, which yielded $479,000 \mathrm{~m}^{3}$ of gas per day on initial tests - is on the downthrown side of this fault. Whether such faulting is widespread and might be associated with hydrocarbon traps is unknown at present.

Drape structures related to rift or prerift tectonism along the shelf edge and slope may be hydrocarbon traps. These drape structures formed by the draping of postrift sediments over older uplifted fault blocks. On seismic sections, these structures appear to be numerous, to be about 5-10 km wide, and to involve several hundred meters of relief. Movement of these basement blocks possibly continued throughout Cretaceous time, thereby increasing the chance that significant anticlinal and fault-related hydrocarbon traps exist.

Although basal Jurassic sedimentary rocks probably contain thick evaporite deposits, the only direct evidence of possible salt flowage comes from the Houston Oil and Minerals 676-1 well, which was reported to have penetrated a significant amount of salt at a depth of about $3,800 \mathrm{~m}$. However, Grow and Klitgord (this volume) speculate that seismic data from the lower slope and rise may indicate the presence of salt diapirs.

Additional but more speculative types of traps on the shelf include updip pinchouts of Jurassic and possibly Lower Cretaceous clastic units against crystalline basement rock. Significant lateral variations in porosity and permeability could likewise be present in marine carbonate rocks of Jurassic and Cretaceous age near the shelf edge. Such porosity and permeability changes could be in fractured limestone and porous reef material and could include secondary porosity in back-reef dolomites. Downdip facies changes from marine clastic to carbonate rocks and from marginalmarine sandstone to shale could also provide stratigraphic traps.

Seismic and indirect geologic evidence suggests that potential hydrocarbon traps are on the slope as well as on the shelf. What is now the Continental Slope may be underlain by sequences of Lower
Cretaceous and Jurassic sedimentary rocks deposited above a carbonate platform or possibly atop high-standing basement blocks during periods of fluctuating sea level. The landward shift of the present shelf edge relative to the buried paleoshelf edge is $20-30 \mathrm{~km}$.

During Early Cretaceous or Late Jurassic time, reef growth apparently began at the edge of the paleoshelf. Deltaic sands and some shales were deposited contemporaneously in the back-reef area, and because delta progradation and contemporaneous reef growth are in general incompatible, the presence or absence of carbonate deposits in local areas in the Early Cretaceous probably depended largely on the volume of local terrigenous input. On seismic sections, reefs appear to be discontinuous, and the eastern margin of the Baltimore Canyon Trough section thus shows a relatively narrow and restricted band of bankmargin carbonate rocks. Some of the deltaic sand may have been funneled through channels in the reef contemporaneously with reef growth, or it may have been swept over the reef as sheet deposits during periodic fluctuations of sea level. Thus, clastic terrigenous sand, fine-grained pelagic and hemipelagic material, and reef debris were probably all deposited on the paleoslope in front of the paleoshelf.

The importance of the paleoshelf edge, as far as petroleum is concerned, is the fact that it is a large high that could contain zones of very porous carbonate rock in both reefal and carbonate platform material. This high is probably bordered on its seaward flank by at least $6 \mathrm{~km}$ of turbidite deposits likely to be rich in preserved organic material. Furthermore, thick shale beds, which apparently overlie the paleoshelf, could provide a relatively impermeable seal needed to trap the migrating fluids.

In order for the paleoshelf high to have trapped migrating fluids, paths of migration from the proposed source beds to the suspected trap must exist. Turbidite deposits commonly consist of thin beds of alternating fine-grained material and coarser sand. These thin sand beds are generally continuous over large areas and hence, hydrocarbons could have migrated essentially updip, but possibly down section, to reservoir rocks in the Mesozoicshelf high. Down-to-the-basin growth faults, that are beneath the present rise may have interrupted the flow of migrating fluids, but in places, migra- 
tion may have followed paths along these faults or through large fan complexes.

Whether hydrocarbons, once they migrated into the paleoshelf high, would have been trapped or whether they would have leaked out is not known. Shales of Cretaceous and Cenozoic age are inferred to overlie the paleoshelf edge. If fluids migrated after the deposition of these shales, the shales could provide the necessary impermeable seal above the paleoshelf-margin high. Also, carbonate rocks can act as a seal under certain diagenetic conditions and as a reservoir under other diagenetic conditions.

If hydrocarbons are contained in the paleoshelf high, we could be looking at large traps. According to Moody (1975), almost 40 percent of the world's oil reserves are in carbonate rocks. The reef trends in the Edwards Limestone of Texas and the El Abra-Tamaulipas Formation of Mexico provide good examples for comparison.

\section{REFERENGES CITED}

Alem, Amid, 1974, Petroleum developments in North Africa in 1973-Morocco: American Association of Petroleum Geologists Bulletin, v. 58, no. 10, p. 2029.

Aymé, J. M., 1965, The Senegal salt basin, in Institute of Petroleum and Geological Society of London, Salt basins around Africa: Amsterdam, Elsevier, p. 83-90.

Bally, A. W., 1976, Canada's passive continental marginsA review: Marine Geophysical Researches, v. 2, no. 4, p. 327-340.

Bartenstein, Helmut, and Teichmüller, Rolf, 1974, Inkohlungsuntersuchungen, ein Schlüssel zur Prospektierung von paläozoischen KohlenwasserstoffLagerstätten? [Coalification research, a key to exploration for hydrocarbon deposits?]: Fortschritte in der Geologie von Rheinland und Westfalen, v. 24, p. 129-160 (Includes English summary.)

Bebout, D. G., and Loucks, R. G., 1974, Stuart City trend, Lower Cretaceous, south Texas-A carbonate shelf-margin model for hydrocarbon exploration: Texas University Bureau of Economic Geology Report of Investigations no. $78,80 \mathrm{p}$.

Berger, W. H., 1974, Deep-sea sedimentation, in Burk, C. A., and Drake, C. L., eds., The geology of continental margins: New York, Springer-Verlag, p. 213-241.

Bott, M. H. P., 1971, Evolution of young continental margins and formation of shelf basins: Tectonophysics, v. 11, no. 5 , p. 319-327.

Brown, P. M., Miller, J. A., and Swain, F. M., 1972, Structural and stratigraphic framework and spatial distribution of permeability of the Atlantic Coastal Plain, North Carolina to New York: U.S. Geological Survey Professional Paper $796,79 \mathrm{p}$.
Bujak, J. P., Barss, M. S., and Williams, G. L., 1977, Offshore east Canada's organic type and color and hydrocarbon potential: Oil und Gas Journal, v. 75, no. 14, p. 198-202.

Christopher, R. A., 1977, Selected Normapolles pollen genera and the age of the Raritan and Magothy Formations (Upper Cretaceous) of northern New Jersey, in Owens, J. P., Sohl, N. F., and Minard, J. P., 1977, [A field guide to] Cretaceous and lower Tertiary beds of the Raritan and Salisbury embayments, New Jersey, Delaware, and Maryland: American Association of Petroleum Geologists/Society of Economic Paleontologists and Mineralogists Annual Meeting, June 12-16, 1977, Washington, D.C., Guidebook [3], p. 58-69, figs. 69-76, 1 pl.

Claypool, G. E., Lubeck, C. M., Baysinger, J. P., and Ging, T. G., 1977, Organic geochemistry, in Scholle, P. A., ed., Geological studies on the COST No. B-2 well, U.S. midAtlantic Outer Continental Shelf area: U.S. Geological Survey Circular 750, p. 46-62.

Cottençon, A., Parant, B., and Flacelière, G., 1975, Lower Cretaceous gasfields in Holland, in Woodland, A. W., ed., Petroleum and the Continental Shelf of north-west Europe-vol. 1, Geology: New York, Wiley, p. 403-412.

Curray, J. R., 1975, Marine sediments, geosynclines, and orogeny, in Fischer, A. G., and Judson, Sheldon, eds., Petroleum and global tectonics: Princeton, N.J., Princeton University Press, p. 157-222.

Dillon, W. P., Paull, C. K., Buffler, R. T., and Fail, Jean-Pierre, 1979, Structure and development of the Southeast Georgia Embayment and northern Blake Plateau-Preliminary analysis, in Watkins, J. S., Montadert, Lucien, and Dickerson, P. W., eds., Geological and geophysical investigations of continental margins: American Association of Petroleum Geologists Memoir 29, p. 27-41, 13 figs.

Doyle, J. A., and Robbins, E. I., 1977, Angiosperm pollen zonation of the continental Cretaceous of the Atlantic Coastal Plain and its application to deep wells in the Salisbury Embayment: Palynology, v. 1, p. 43-78, 5 figs., 7 pls.

Drake, C. L., Ewing, Maurice, and Sutton, G. H., 1959, Continental margins and geosynclines - the east coast of North America north of Cape Hatteras, in Ahrens, L. H., and others, eds., Physics and chemistry of the earth, v. 3: London, Pergamon Press, p. 110-198.

Drake, C. L., Heirtzler, J., and Hirshman, J., 1963, Magnetic anomalies off eastern North America: Journal of Geophysical Research, v. 68, no. 18, p. 5259-5275.

Emery, K. O., and Uchupi, Elazar, 1972, Western North Atlantic Ocean; Topography, rocks, structure, water, life and sediments: American Association of Petroleum Geologists Memoir 17, $532 \mathrm{p}$.

Emery, K. O., Uchupi, Elazar, Phillips, J. D., Bowin, C. O., Bunce, E. T., and Knott, S. T., 1970, Continental Rise off eastern North America: American Association of Petroleum Geologists Bulletin, v. 54, no. 1, p. 44-108, 46 figs.

Emery, K. O., Uchupi, Elazar, Phillips, Joseph, Bowin, Carl, and Mascle, Jean, 1975, Continental margin off western Africa; Ängola to Sierra Leone: American Association of Petroleum Geologists Bulletin, v. 59, no. 12, p. 2209-2265.

Enos, Paul, 1974, Reefs, platforms, and basins of Middle Cretaceous in northeast Mexico: American Association of Petroleum Geologists Bulletin, v. 58, no. 5, p. 800-809, 9 figs. 
Ericson, D. B., Ewing, Maurice, Wollin, Goesta, and Heezen, B. C., 1961, Atlantic deep-sea sediment cores: Geological Society of America Bulletin, v. 72, no. 2, p. 193-286, 50 figs., 3 pls.

Evans, Robert, 1977, Origin and significance of evaporites in basins around Atlantic margin [abs.]: American Association of Petroleum Geologists and Society of Economic Paleontologists and Mineralogists Annual Meeting Abstracts, v. 4, p. 47.

Ewing, John, and Ewing, Maurice, 1959, Seismic-refraction measurements in the Atlantic Ocean basins, in the Mediterranean Sea, on the Mid-Atlantic Ridge, and in the Norwegian Sea: Geological Society of America Bulletin, v. 70, no. 3, p. 291-318.

Ewing, John, Windisch, Charles, and Ewing, Maurice, 1970, Correlation of Horizon A with JOIDES bore-hole results: Journal of Geophysical Research, v. 75, no. 29, p. 5645-5653, 8 figs.

Ewing, John, Worzel, J. L., Ewing, Maurice, and Windisch, Charles, 1966, Ages of Horizon A and the oldest Atlantic sediments: Science, v. 154, no. 3753, p. 1125-1132, 6 figs.

Ewing, Maurice, Worzel, J. L., Steenland, N. C., and Press, Frank, 1950, Geophysical investigations in the emerged and submerged Atlantic Coastal Plain; Part V, Woods Hole, New York, and Cape May sections: Geological Society of America Bulletin, v. 61, no. 9, p. 877-892, 2 figs., 6 pls.

Falvey, D. A., 1974, The development of continental margins in plate tectonic theory: Australian Petroleum Exploration Association Journal, v. 14, no. 1, p. 95-106.

Fischer, A. G., 1969, Geological time-distance rates; The Bubnoff unit: Geological Society of America Bulletin, v. 80, no. 3, p. 549-551, 1 fig.

Gardner, G. H. F., Gardner, L. W., and Gregory, A. R. 1974, Formation velocity and density - the diagnostic basics for stratigraphic traps: Geophysics, v. 39 , no. 6, p. 770-780, 9 figs.

Garrison, L. E., 1970, Development of Continental Shelf south of New England: American Association of Petroleum Geologists Bulletin, v. 54, no. 1, p. 109-124, 10 figs.

Geotimes, 1970, Deep Sea Drilling Project-Leg 11: v. 15, no. 7, p. 14-16.

1975, The eastern North Atlantic [Leg 41 of the Deep Sea Drilling Project]: v. 20, no. 7, p. 18-21.

1976, In the North Atlantic-Deep-sea drilling [Leg 44 of the Deep Sea Drilling Project]: v. 21, no. 2, p. 23-26.

Gibson, T. G., Hazel, J. E., and Mello, J. F., 1968, Fossiliferous rocks from submarine canyons off the northeastern United States: U.S. Geological Survey Professional Paper 600-D, p. D222-D230.

Given, M. M., 1977, Mesozoic and early Cenozoic geology of offshore Nova Scotia: Bulletin of Canadian Petroleum Geology, v. 25, no. 1, p. 63-91.

Grow, J. A., Bowin, C. O., Hutchinson, D. R., and Kent, K. M., 1976, Preliminary free-air gravity anomaly map along the Atlantic continental margin between Virginia and Georges Bank: U.S. Geological Survey Miscellaneous Field Studies Map MF-795, scale 1:1,200,000.

Grow, J. A., Dillon, W. P., and Sheridan, R. E. 1977, Diapirs along Continental Slope off Cape Hatteras [abs.]: Society of Exploration Geophysicists, 47th Annual International Meeting, Calgary, Alberta, Program, p. 51.
Grow, J. A., and Markl, R. G., 1977, IPOD-USGS multichannel seismic reflection profile from Cape Hatteras to the MidAtlantic Ridge: Geology, v. 5, no. 10, p. 625-630, 8 figs.

Grow, J. A., Mattick, R. E., and Schlee, J. S., 1979, Multichannel seismic depth sections and interval velocities over Outer Continental Shelf and Upper Continental Slope between Cape Hatteras and Cape Cod, in Watkins, J. S., Montadert, Lucien, and Dickerson, P. W., eds., Geological and geophysical investigations of continental margins: American Association of Petroleum Geologists Memoir 29, p. 65-83, 14 figs.

Grow, J. A., and Schlee, John, 1976, Interpretation and velocity analysis of U.S. Geological Survey multichannel reflection profiles 4,5 , and 6 , Atlantic continental margin: U.S. Geological Survey Miscellaneous Field Studies Map MF-808.

Hartman, R. R., Teskey, D. J., and Friedberg, J. L., 1971, A system for rapid digital aeromagnetic interpretation: Geophysics, v. 36, no. 5, p. 891-918, 21 figs.

Hathaway, J. C., and others, eds., 1976, Preliminary summary of the 1976 Atlantic margin coring project of the U.S. Geological Survey: U.S. Geological Survey Open-File Report 76-844, 217 p.

Hays, J. D., and Pitman, W. C., III, 1973, Lithospheric plate motion, sea level changes, and climatic and ecological consequences: Nature, v. 246 , no. 5427, p. $18-22,4$ figs.

Hazel, J. E., Distribution of some biostratigraphically diagnostic ostracodes in the Pliocene and lower Pleistocene of Virginia and northern North Carolina: U.S. Geological Survey Journal of Research, v. 5, no. 3, p. 373-388.

Hollister, C. D., 1973, Atlantic Continental Shelf and Slope of the United States - Texture of surface sediments from New Jersey to southern Florida: U.S. Geological Survey Professional Paper 529-M, 23 p.

Hood, A., and Castaño, J. R., 1974, Organic metamorphismIts relationship to petroleum generation and application to studies of authigenic minerals: United Nations Economic Commission for Asia and the Far East, Committee for Coordination of Joint Prospecting for Mineral Resources in Asia Offshore Areas, Technical Bulletin, v. 8, p. 85-118.

Hood, A., Gutjahr, C. C. M., and Heacock, R. L., 1975, Organic metamorphism and the generation of petroleum: American Association of Petroleum Geologists Bulletin, v. 59, no. 6, p. 986-996, 7 figs.

Hülseman, Jobst, 1967, The continental margin off the Atlantic coast of the United States; Carbonate in sediments, Nova Scotia to Hudson Canyon: Sedimentology, v. 8, no. 2, p. 121-145.

Jain, Sudhir, 1976, An automatic method of direct interpretation of magnetic profiles: Geophysics, v. 41, no. 3, p. $531-541,6$ figs.

Jansa, L. F., and Wade, J. A., 1975a, Geology of the continental margin off Nova Scotia and Newfoundland, in Van der Linden, W. J. M., and Wade, J. A., eds., Offshore geology of eastern Canada, vol. 2, Regional geology: Canada Geological Survey Paper 74-30, p. 51-105, 33 figs. $1975 \mathrm{~b}$, Paleogeography and sedimentation in the Mesozoic and Cenozoic, southeastern Canada, in Yorath, C. J., Parker, E. R., and Glass, D. J., eds., Canada's continental margins and offshore petroleum exploration: Canadian Society of Petroleum Geologists Memoir 4, p. 79-102, 17 figs. 
Keller, Fred, Jr., Meuschke, J. L., and Alldredge, L. R., 1954, Aeromagnetic surveys in the Aleutian, Marshall, and Bermuda Islands: American Geophysical Union Transactions, v. 35 , p. 558-572, 12 figs.

King, L. H., 1975, Geosynclinal development on the continental margin south of Nova Scotia and Newfoundland, in Van der Linden, W. J. M., and Wade, J. A., eds., Offshore geology of eastern Canada, vol. 2, Regional geology: Canada Geological Survey Paper 74-30, p. 199-206, 3 figs.

Kinsman, D. J. J., 1975, Rift valley basins and sedimentary history of trailing continental margins, in Fischer, A. G., and Judson, Sheldon, eds., Petroleum and global tectonics: Princeton, N.J., Princeton University Press, p. 83-126, 10 figs.

Klitgord, K. D., and Behrendt, J. C., 1979, Basin structure of the U.S. Atlantic margin, in Watkins, J. S., Montadert, Lucien, and Dickerson, P. W., eds., Geological and geophysical investigations of continental margins: American Association of Petroleum Geologists Memoir 29, p. 85-112, 15 figs.

Knebel, H. J., and Spiker, Elliott, 1977, Thickness and age of surficial sand sheet, Baltimore Canyon trough area: American Association of Petroleum Geologists Bulletin, v. 61,6, p. 861-871.

Lancelot, Yves, Hathaway, J. C., and Hollister, C. D., 1972, Lithology of sediments from the western North Atlantic Leg II Deep Sea Drilling Project, in California University, Scripps Institution of Oceanography, La Jolla, Initial reports of the Deep Sea Drilling Project, Volume XI***: Washington, D. C., National Science Foundation, p. 901-949, 27 figs.

Lévy, R. G., Perrodon, A., Alem, A., Kanouni, A., and Nicod, M. A., 1975, Morocco, in Owen, E. W., Trek of the oil finders-A history of exploration for petroleum: American Association of Petroleum Geologists Memoir 6, p. 1471-1483.

Maher, J. C., 1965, Correlations of subsurface Mesozoic and Cenozoic rocks along the Atlantic coast: Tulsa, Okla., American Association of Petroleum Geologists, $18 \mathrm{p}$.

Maher, J. C., and Applin, E. R., 1971, Stratigraphy, in Maher, J. C., Geologic framework and petroleum potential of the Atlantic Coastal Plain and Continental Shelf: U.S. Geological Survey Professional Paper 659, p. 26-56.

Mattick, R. E., Foote, R. Q., Weaver, N. L., and Grim, M. S., 1974, Structural framework of United States Atlantic Outer Continental Shelf north of Cape Hatteras: American Association of Petroleum Geologists Bulletin, v. 58, no. 6, pt. 2, p. 1179-1190, 10 figs.

Mattick, R. E., Girard, O. W., Jr., Scholle, P. A., and Grow, J. A., 1977, Potential of deep Atlantic targets examined: Oil and Gas Journal, v. 75, no. 51, p. 102-107.

1978, Petroleum potential of U.S. Atlantic slope, rise, and abyssal plain: American Association of Petroleum Geologists Bulletin, v. 62 , no. 4, p. 592-608, 8 figs.

Mayhew, M. A., 1974, "Basement" to east coast continental margin of North America: American Association of Petroleum Geologists Bulletin, v. 58, no. 6, pt. 2, p. 1069-1088, 10 figs.

McGregor, B. A., and Bennett, R. H., 1977, Continental Slope sediment instability northeast of Wilmington Canyon: American Association of Petroleum Geologists Bulletin, v. 61 , no. 6 , p. $918-928,8$ figs.
McIver, N. L., 1972, Cenozoic and Mesozoic stratigraphy of the Nova Scotia shelf: Canadian Journal of Earth Sciences, v. 9 , no. 1 , p. 54-70, 5 figs.

Meisburger, E. P., 1977, Shallow framework of Inner Continental Shelf of Cape Fear region, North Carolina [abs.] American Association of Petroleum Geologists Bulletin, v. 61 , no. 5, p. 812-813.

Meyerhoff, A. A., and Morris, A. E. L., 1977, Central America petroleum potential centered mostly in Mexico: Oil and Gas Journal, v. 75, no. 43, p. 104-109.

Milliman, J. D., Pilkey, O. H., and Ross, D. A., 1972, Sediments of the continental margin off the eastern United States: Geological Society of America Bulletin, v. 83, no. 5, p. 1315-1334, 14 figs.

Minard, J. P., Perry, W. J., Weed, E. G. A., Rhodehamel, E. C., Robbins, E. I., and Mixon, R. B., 1974, Preliminary report on geology along Atlantic continental margin of northeastern United States: American Association of Petroleum Geologists Bulletin, v. 58, no. 6, pt. 2, p. 1169-1178, 7 figs.

Moody, J. D., 1975, Distribution and geological characteristics of giant oil fields, in Fischer, A. G., and Judson, Sheldon, eds., Petroleum and global tectonics: Princeton, N. J., Princeton University Press, p. 307-320, 12 figs.

Parsons, M. G., 1975, The geology of the Laurentian fan and the Scotia rise, in Yorath, C. J., Parker, E. R., and Glass, D. J., eds., Canada's continental margins and offshore petroleum exploration: Canadian Society of Petroleum Geologists Memoir 4, p. 155-167, 15 figs.

Payton, C. E., ed., 1977, Seismic stratigraphy-Applications to hydrocarbon exploration: American Association of Petroleum Geologists Memoir 26, 516 p.

Perry, W. J., Jr., Minard, J. P., Weed, E. G. A., Robbins, E. I., and Rhodehamel, E. C., 1975, Stratigraphy of Atlantic coastal margin of United States north of Cape Hatteras-Brief survey: American Association of Petroleum Geologists Bulletin, v. 59, no. 9, p. 1529-1548, 12 figs.

Poag, C. W., 1977, Foraminiferal biostratigraphy, in Scholle, P. A., ed., Geological studies on the COST No. B-2 well, U.S. mid-Atlantic Outer Continental Shelf area: U.S. Geological Survey Circular 750, p. 35-36.

1978, Stratigraphy of the Atlantic Continental Shelf and Slope of the United States: Annual Review of Earth and Planetary Sciences, v. 6, p. 251-280.

Pusey, W. C., III, 1973, The ESR-kerogen method-How to evaluate potential gas and oil source rocks: World Oil, v. 176, no. 5, p. 71-75, 4 figs.

Rabinowitz, P. D., 1974, The boundary between oceanic and continental crust in the western North Atlantic, in Burk, C. A., and Drake, C. L., eds., The geology of continental margins: New York, Springer-Verlag, p. 67-84.

Rabinowitz, P. D., and LaBrecque, J. L., 1977, The isostatic gravity anomaly: Key to evolution of the oceancontinent boundary at passive continental margins: Earth and Planetary Science Letters, v. 35, no. 1, p. 145-150.

Rich, J. L., 1951, Three critical environments of deposition, and criteria for recognition of rocks deposited in each of them: Geological Society of America Bulletin, v. 62, no. 1, p. 1-19, 2 figs., 4 pls.

Rhodehamel, E. C., 1977, Lithologic descriptions, in Scholle, P. A., ed., Geological studies on the COST No. B-2 well, U.S. mid-Atlantic Outer Continental Shelf area: U.S. Geological Survey Circular 750, p. 15-22. 
Robbins, E. I., and Rhodehamel, E. C., 1976, Geothermal gradients help predict petroleum potential of Scotian Shelf: Oil and Gas Journal, v. 74, no. 9, p. 143-145.

Rona, P. A., 1970, Comparison of continental margins of eastern North America at Cape Hatteras and northwestern Africa at Cape Blanc: American Association of Petroleum Geologists Bulletin, v. 54, no. 1, p. 129-157, 10 figs.

Rose, P. R., 1963, Comparison of the type El Abra of Mexico with "Edwards Reef trend" of south-central Texas, in Corpus Christi Geological Society, Geology of Peregrina Canyon and Sierra de El Abra, Mexico-Annual field trip, 1963: Corpus Christi, Tex., p. 57-64.

Schlee, John, 1973, Atlantic Continental Shelf and Slope of the United States - Sediment texture of the northeastern part: U.S. Geological Survey Professional Paper 529-L, 64 p.

Schlee, John, Behrendt, J. C., Grow, J. A., Robb, J. M., Mattick, R. E., Taylor, P. T., and Lawson, B. J., 1976, Regional geologic framework off northeastern United States: American Association of Petroleum Geologists Bulletin, v. 60 , no. 6, p. 926-951, 23 figs.

1977, Regional geologic framework off northeastern United States; Reply: American Association of Petroleum Geologists Bulletin, v. 61, no. 5, p. 742-743.

Schlee, J. S., Martin, R. G., Mattick, R. E., Dillon, W. P., and Ball, M. M., 1977, Petroleum geology on the United States Atlantic-Gulf of Mexico margins, in v. 15 of Institute on Petroleum Exploration and Economics, Exploration and economics of the petroleum industry; New ideas, new methods, new developments: New York, Matthew Bender, p. 47-93, 16 figs.

Scholle, P. A., 1977a, Data summary and petroleum potential, in Scholle, P. A., ed., Geological studies on the COST No. B-2 well, U.S. mid-Atlantic Outer Continental Shelf area: U.S. Geological Survey Circular 750, p. 8-14.

$\longrightarrow$, ed., 1977b, Geological studies on the COST No. B-2 well, U.S. mid-Atlantic Outer Continental Shelf area: U.S. Geological Survey Circular 750, 71 p., 22 figs.

Scholle, P. A., and Arthur, M. A., 1976, Carbon-isotopic fluctuations in Upper Cretaceous sediments; an indicator of paleo-oceanic circulation [abs.]: Geological Society of America Abstracts with Programs, v. 8, no. 6, p. 1089.

Sclater, J. G., Anderson, R. N., and Bell, M. L., 1971, Elevation of ridges and evolution of the central eastern Pacific: Journal of Geophysical Research, v. 76, no. 32, p. 7888-7915, 15 figs.

Sheridan, R. E., 1974, Atlantic continental margin of North America, in Burk, C. A., and Drake, C. L., eds., The geology of continental margins: New York, SpringerVerlag, p. 391-407.

1976, Sedimentary basins of the Atlantic margin of North America, in Bott, M. H. P., ed., Sedimentary basins of continental margins and cratons: New York, Elsevier Scientific Publishing Company, p. 113-132. (Reprinted from Tectonophysics, v. 36, nos. 1-3, p. 113-132.)

Sheridan, R. E., Dill, C. E., Jr., and Kraft, J. C., 1974, Holocene sedimentary environment of the Atlantic inner shelf off Delaware: Geological Society of America Bulletin, v. 85 , no. 8 , p. 1319-1328, 13 figs.

Sheridan, R. E., Smith, J. D., and Gardner, J., 1969, Rock dredges from Blake Escarpment near Great Abaco Canyon: American Association of Petroleum Geologists Bulletin, v. 53 , no. 12 , p. $2551-2558$.
Sirkin, L. A., 1974, Palynology and stratigraphy of Cretaceous strata in Long Island, New York, and Block Island, Rhode Island: U.S. Geological Survey Journal of Research, v. 2, no. 4, p. 431-440, 7 figs.

Sleep, N. H., 1971, Thermal effects of the formation of the Atlantic continental margins by continental breakup: Royal Astronomical Society Geophysical Journal, v. 24, no. 4, p. 325-350.

Smith, M. A., Amato, R. V., Furbush, M. A., Pert, D. M., Nelson, M. E., Hendrix, J. S., Tamm, L. C., Wood, G., Jr., and Shaw, D. R., 1976, Geological and operational summary, COST No. B-2 well, Baltimore Canyon trough area, mid-Atlantic OCS: U.S. Geological Survey Open-File Report 76-774, 79 p., 1 pl., 14 figs.

Stahl, L., Koczan, J., and Swift, D. J. P., 1974, Anatomy of a shore-face connected sand ridge on the New Jersey shelf: Implications for the genesis of the shelf surficial sand sheet: Geology, v. 2, no. 3, p. 117-120.

Sutton, G. H., Maynard, G. L., and Hussong, D. M., 1971, Widespread occurrence of a high-velocity basal layer in the Pacific crust found with repetitive sources and sonobuoys, in Heacock, J. G., ed., The structure and physical properties of the earth's crust: American Geophysical Union Geophysical Monograph 14, p. 193-209.

Talley, J. H., 1975, Cretaceous and Tertiary section, deep test well, Greenwood, Delaware: Delaware Geological Survey Report of Investigations 23, $51 \mathrm{p}$.

Taylor, P. T., Zietz, Isidore, and Dennis, L. S., 1968, Geologic implications of aeromagnetic data for the eastern continental margin of the United States: Geophysics, v. 33, no. 5 , p. 755-780, 9 figs.

Texaco, 1978, Additional potential confirmed in Baltimore Canyon discovery: News from Texaco, Inc., August 18, 1978, $1 \mathrm{p}$

Tissot, B. P., Durand, B., Espitalié, J., and Combaz, A., 1974 , Influence of nature and diagenesis of organic matter in formation of petroleum: American Association of Petroleum Geologists Bulletin, v. 58, no. 3, p. 499-506, 12 figs.

U.S. Geological Survey, 1976, Aeromagnetic maps of Atlantic continental margin quadrangles: U.S. Geological Survey Miscellaneous Field Studies Maps MF-752-A-H, scale 1:250,000.

Vail, P. R., Mitchum, R. M., Jr., Todd, R. G., Widmier, J. M., Thompson, S., III, Sangree, J. B., Bubb, J. N., and Hatlelid, W. G., 1977, Seismic stratigraphy and global changes of sea level, in Payton, C. E., ed., Seismic stratigraphy - Applications to hydrocarbon exploration: American Association of Petroleum Geologists Memoir 26, p. 49-205.

Valentine, P. C., 1977, Nannofossil biostratigraphy, in Scholle, P. A., ed., Geological studies on the COST No. B-2 well, U.S. mid-Atlantic Outer Continental Shelf area: U.S. Geological Survey Circular 750, p. 37-40.

Van Houten, F. B., 1977, Triassic-Liassic deposits of Morocco and eastern North America; Comparison: American Association of Petroleum Geologists Bulletin, v. 61, no. 1, p. 79-99, 4 figs.

Vassoyevich, N. B., Korchagina, Y. I., Lopatin, N. V., and Chernyshev, V. V., 1969, Glavnaya faza nefteobrazovaniya [Principal phase of oil formation]: Moskovskiy Universitet Vestnik, Seriya Geologii, v. 24, no. 6, p. 3-27. (English translation in International Geology Review, v. 12, no. 11, p. 1276-1296, 13 figs., 1970.) 
Watts, A. B., and Ryan, W. B. F., 1976, Flexure of the lithosphere and continental margin basins: Tectonophysics, $v$. 36, p. 25-44.

Weed, E. G. A., Minard, J. P., Perry, W. J., Jr., Rhodehamel, E. C., and Robbins, E. I., 1974, Generalized pre-Pleistocene geologic map of the northern United States Atlantic continental margin: U.S. Geological Survey Miscellaneous Investigations Series Map I-861, 8 p., 2 sheets, scale $1: 1,000,000$.

Werner, S., 1953, Interpretation of magnetic anomalies at sheet-like bodies: Sveriges Geologiska Undersökning, Årsbok 43, no. 6 ser. c, no. 508.

Wolfe, J. A., 1976, Stratigraphic distribution of some pollen types from the Campanian and lower Maestrichtian rocks (Upper Cretaceous) of the Middle Atlantic States: U.S. Geological Survey Professional Paper 977, 18 p., 4 pls.
Woollard, G. P., 1962, The relation of gravity anomalies to surface elevation, crustal structure and geology: Wisconsin University, Geophysical and Polar Research Center Research Report Series, no. 62-9, 1 vol., variously paged. Worzel, J. L., 1965, Pendulum gravity measurements at sea, 1936-1959: New York, John Wiley and Sons, 422 p.

Worzel, J. L., and Shurbet, G. L., 1955, Gravity interpretations from standard oceanic and continental crustal sections, in Poldervaart, Arie, ed., Crust of the Earth (A symposium): Geological Society of America Special Paper 62 , p. $87-100,5$ figs.

Yarborough, Hunter, 1977, Continental margin types related to plate tectonics and evolution of margins, in Geology of continental margins: American Association of Petroleum Geologists Continuing Education Course Note Series, no. 5, p. A1-A8. 
